University of Windsor

Scholarship at UWindsor

\title{
Reinforced earth retaining wall under vertical and horizontal strip loading.
}

Peter H. Seymour
University of Windsor

Follow this and additional works at: https://scholar.uwindsor.ca/etd

\section{Recommended Citation}

Seymour, Peter H., "Reinforced earth retaining wall under vertical and horizontal strip loading." (1982). Electronic Theses and Dissertations. 3300.

https://scholar.uwindsor.ca/etd/3300

This online database contains the full-text of PhD dissertations and Masters' theses of University of Windsor students from 1954 forward. These documents are made available for personal study and research purposes only, in accordance with the Canadian Copyright Act and the Creative Commons license-CC BY-NC-ND (Attribution, Non-Commercial, No Derivative Works). Under this license, works must always be attributed to the copyright holder (original author), cannot be used for any commercial purposes, and may not be altered. Any other use would require the permission of the copyright holder. Students may inquire about withdrawing their dissertation and/or thesis from this database. For additional inquiries, please contact the repository administrator via email (scholarship@uwindsor.ca) or by telephone at 519-253-3000ext. 3208. 
CANADIAN THESES ON MICROFICHE

\section{THESES CANADIENNES SUR MICROFICHE}

National Library of Canada Collections Development Branch

Canadian Theses on Micr ofiche Service

Ottawa, Canada K1A ON4
Bibliothèque nationale, du Canada Direction du développement des collections

\section{Service des thèses canadiennes} - sur microfiche

\section{NOTICE}

The quality of this microfiche is heavily dependent upon the quality of the original thesis submitted for microfilming. Every effort has been made to ensure the highest quality of reproduction possible.

If pages are missing, contact the university which granted the degree.

Some pages may have indistinct print especially if the original pages were typed with a poor typewriter ribbon or if the university sent us a poor photocopy.

Previously copyrighted materials (journal articles, published tests, etc.) are not filmed.

Reproduction in full or in part of this film is governed by the Canadian Copyright Act, R.S.C. 1970 , c. C-30. Please read the authorization forms which accompany this thesis.

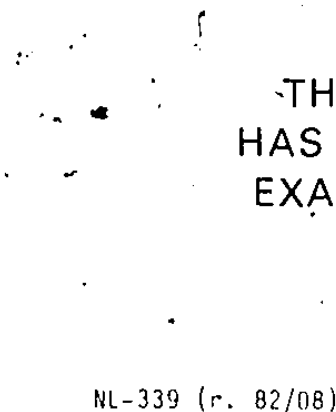

La qualité de cette microfiche dépend grandement de la qualité de la thèse soumise au microfilmage. Nous avons tout fait pour assurer une qualité supérieuré de reproduction.

S'il manque des pages, veuillez communiquer avec l'université qui a conféré le grade.

Là qualité d’impression de certaines pages peut laisser à dësirer, surtout si les pages originales ont èté dactylographiées à l'aide d'un ruban usé ou si l'univer. sité nous a fait parvenir une photocopie de mauvaise qualité.

Les documents qui font déjà l'objet d'un droit d'auteur (articles de revue, examens publies, etc.) ne sont pas:microfilmés.

La reproduction, même partielle, 'de ce microfilm est soumise à la Loi canadienne sur. le droit d'auteur, SRC 1970, c. C.30. Veuillez prendre connaissance des formules d'autorisation qui accompagnent cette thèse.

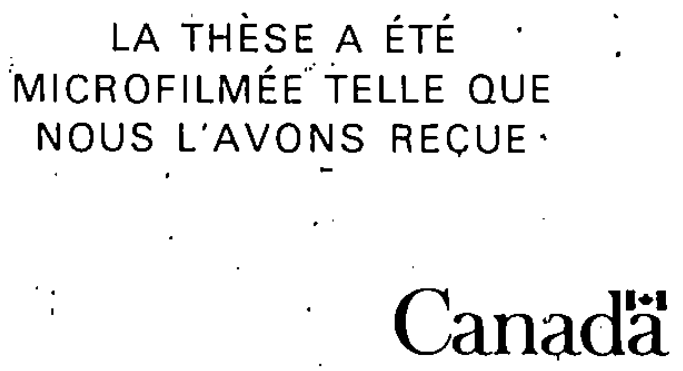




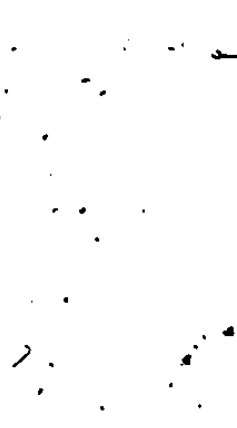

REINFORCED EARTH RETAINING WALL UNDER VERTICAL AND HORIZONTAL STRIP LOADING

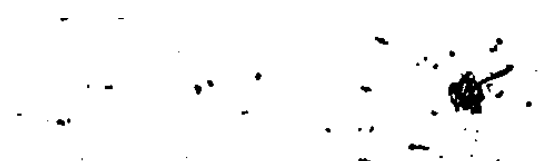$$
\text { . HORIZONTAL STRIP LOADING }
$$

$\therefore=\quad \because \ldots+\infty$

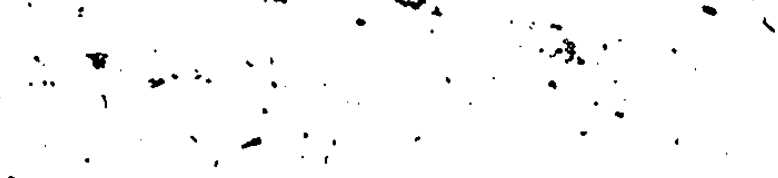

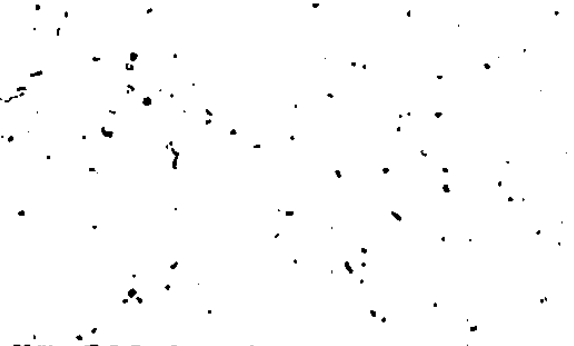

.

-

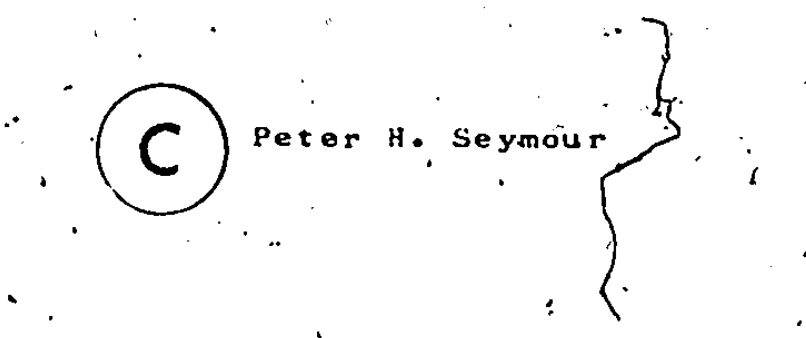

A thesis

presented to the University of Windsor in partial fulfillment of the requirements for the degree of. Master Of Applied Science

, in

CIVIL ENGINEERING

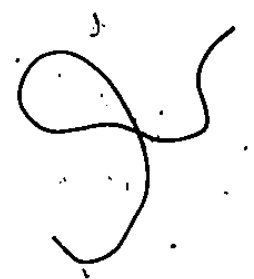

Windsor, Ontario, 1982

(c) Peter H. Seymour, 1982

1 
8

$r$

7
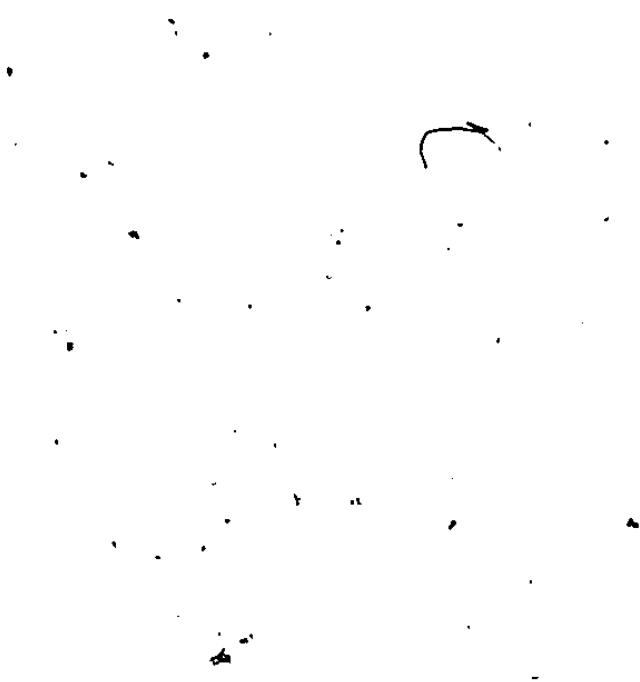

To My Parents

$\bullet$

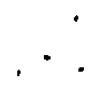





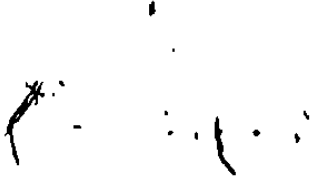

ACXNOWLEDGEMENTS.

The autior wishey to express, his appreciation und gratitude

- to his advisor Draj.T. Laba, for his contínuaus guidance,

- assistance and encouragement throughout the auration of this. work:

- The autnur would also.like to thank Dr.J.B. Eennedy, athis

- co-actisisar, for his helpful commenty and sugigestions. Thanks.

* are also due to Mr. Peter wu, Senior Engineer at The Rein-

porced Earth Co. In Toronto, for some enlighteninis discus-

sions, and his interest th this research.

The aid of Mr. Frank Kiss.and Mr. Peter Eeither during the

experinentul stajes. of this work is greately appreciated.

- The author is also graterul to the Civil Engineering De-

partment at the University of Windsor, and to the Nationsi

kesearch Council of Canda for the opportunity of conducting

this research, under grant number A $27+3$.

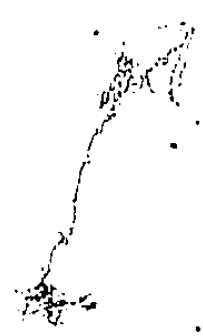


F18. 2.1 Elementary Cube of Unrelnforced Earth ${ }^{-}$. . . . 79

F18. 2.2 Mohr's C1rcie of Stress, and Fallure Envelope

. for the Soll .................... 79

F1g. 2.3 Elementary Cube with Relaforcement ........ 80

F1g. 2.4 R1g1d, Non-moving; Retaining Wall, Suppourting

Granular Backf111 in the At-rest Condition . . . 80

F1g. 2.5 Soll Mass Relnforced with Reinforcing Stíips. ... 81 .

F1g. 2.6 Schemat1c view of the Arch1ng Effect :...... 81

Fig. 2.7 Exteirnal Loads on the Relnforced Earth Ret. Wall • 82

Fig. 2.8 Stresses Exerted on the Reinforcement by Soll : . . 82

Fig. 2.9, Distribution of Vertical Stresses due. to the

Surcharge Load ............. 83

F1g. 2.10 D1stribution of Horizontal Stresses Agalnst a R1gid, Vertical Retalning Wall due to a Surcharge Load ... 83

F1g. 2,11 French-Proposal for Distribution of Horizontal

Stresses within Soll Mass due to Horfiontal $\cdots$

Fíg. 2.12 Effective Length of Relnforcement ....... 84.

Fig. 2.13 Design Values of Soll-Strip Friction ...... 85

F1g. 2.14 Design Values of Coefficient of Lateral Earth Pressure 85

F1g. 2.15 Metal Beam as Earth Reinforcement ........ 85

F1g. 3.1 S1de Elevation of Mode1 ........... 86

Fig. 3.2 Grain Size Distribution Curve for Backfill .... 87

F18. 3.3 Results of Shear Box Test on Sand Backf1ll .... 88

fig. 3.4 Results of Stress-Strain Test on Reinforcing Strip • 89

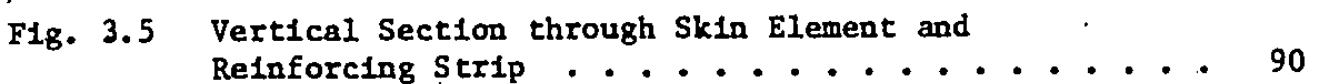

Fig. 3.6 Plan Ylew of Skin Element and Reinforclng Strips • . 90 
F1g. 3.7 Location of Strain Gauges on Strips : . . . . 91

F1g. 3.8 Electronic Strain Gauge Ind1cator $\ldots \ldots \ldots$

F1g. 3.9 Dial Gauges Used to Read Wall Deflection ...... 93

F18. 3.10 Bullding up the Reinforced Earth System . . . . . 94

F1g. 3.11 Loading System . . . . . . . . . . . 95

F1g. 3.12 Loading System . . . . . . . . . . . . 96

F1g. 3.13 Loading System . . . . . . . . . . . . 96

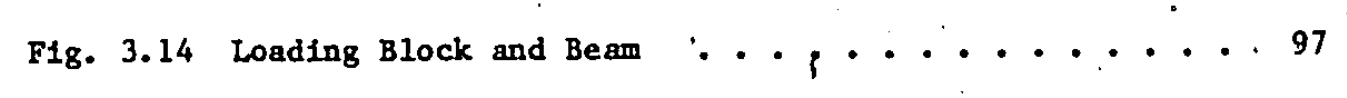

F1g. 3.15 Load Locations . . . . . . . . . . . . . 98

Fig. 4.1 Boussinesq Stress Distribution .......... 99

F18. 4.2 Str1p Traction Force D1stribution, Vertical Load, . 100

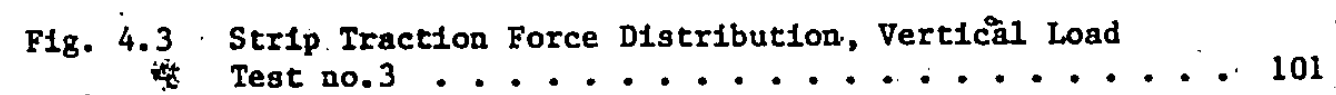

F1g: 4.4 Strip Traction Force D1stribution, Vertical Load . . . . . . . . . . . 102

F1g. 4.5 Str1p Traction Force Distr1but1on, Vert1cal Load
Test no.? . . . . . . . . . 103

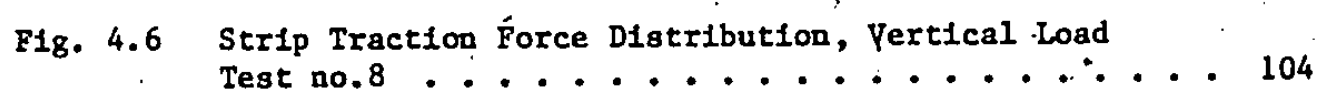

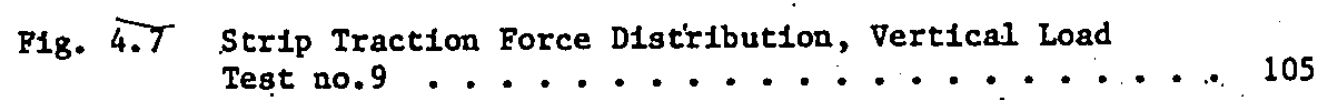

F18. 4.8 Strip Traction Force Distribution, Vert1cal Load . . . 106

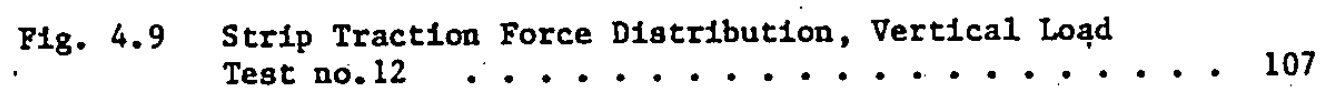

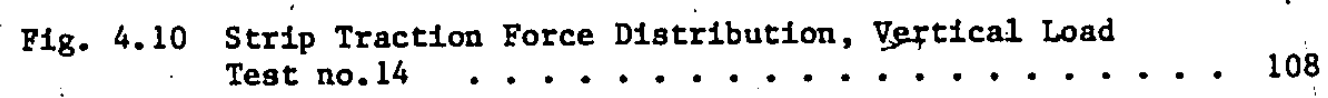

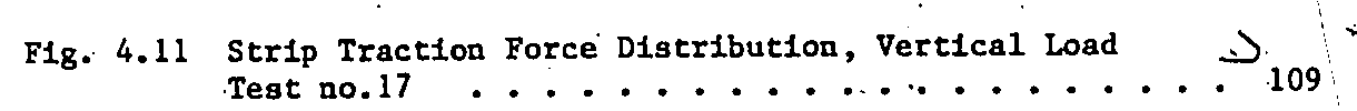

F18. 4.12 Strip Traction Force Distribution, Vertical Load

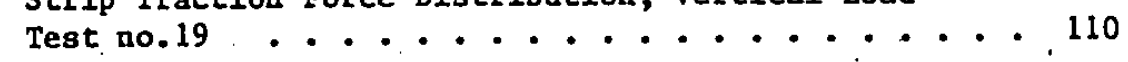

$$
- \text { vis }-
$$


P1g. 4.13 Lócation of Potentlal Fallure Plane; Test no.1 . •. 111

F1g. 4.14 Location of Potential Fallure Plané, Test no. $7^{\circ}$ • ${ }^{\circ} 11$

F18. 4.15 Location of Potentlal Pallure Plane, Test nos, 12,13,14, 112

F18. 4.16 Location of Potential Fallure Plane, Test nos,16,18,19 112

F1g. 4.17 Maximum Traction Force v8. Dépth, Testinos.2,3 . . 113

F18. 4.18 Maximum Traction Force Y8. Depth, Test nos.5,7,9 • . 114

F18. 4.19 Maximum Traction Force vs. Depth, Test nos.12,14 • 115

F18. 4.20. Maximum Traction Force v8. Depth, Test nos.17,19" - 116

118. $4: 21^{3}$ Wall Deflect1on, Vert1cal Load, Test no.l.. .117

F1g. 4.22 wall Deflection, Vertlcal Load, Test no.3 ..... 117

Fig. 4.23 Wall Deflection, Vertical toad, Test no.4 ..... 118

F1g. 4.24 Wall Deflection, Vertical Load, Test no.9 ...... 118

F1g. 4.25 Wall Deflection, Vert1cal Load, Test no.12 .... 119

F18. 4.26 Wall Deflection, Vertical, Load, Test no.14 $\quad \cdots . .119$

F1g. 4.27 Wall Deflectton, Vert1cal Load, Test to.16 $\ldots \because 120$

Fig. 4.28 Wall Deflection, Vertical Load, Test no.18 . . . 120

F1g. 4.29 Change in Str1p Traction Force, Test no.2 . . . 121

F18. 4.30 Change in Strip Traction Force, Test no:8 ..... 121

F1g. 4.31 Change in Strip Traction Force, Test no.11 . . : . 122

F1g. 4.32 Change in Strip Traction Force, Tẹst no.11 . . . 122

F1g. 4.33 Change in Strip Traction Force, Test no.13 .... 123

F1g: 4.34 Change in Strip Traction Force, Test no.15 . . . 123

F18. 4.35 Change in Strip Traction Force, Test no.4 . . . . 124

F18. 4.36 Change in Strip Traction Force, Test no.3 . . . . 124

F18. 4.37 Change in Str1p Traction Force, Test no.7 ..... 125

F18 4.38- Change In Strlp Traction Poree, Test no.14 . . . 125 
F1g. 4.39 Change In Strip Traction Force, Test no.14 . . . 126

F18. 4:40 Change in Strip Traction Force, Test no.18 . . . 126

F1g. 4.41 Shift in Posn. of Max. Traction Force, Test to.1 • - 127

F1g. 4.42 Shift In Posn. of Max. Traction Force, Test no.7 • 127

F1g. 4.43 Shift In Posn. of Max. Traction Force, Test no.5 • 128

F1g. 4.44 Shift in Posn. of Max. Traction Force, Test no.13 . 128

F1g. 4.45 Shift in Posn. of Max. Traction Force, Test no.14 • . 129

F1g. 4.46 Sh1ft in Posn. of Max. Traction Force, Test no.2 . . 129

F1g. 4.47 Change in Max. Traction Forcé, Test no.3 . . . . 130

F1g. 4.48 Change in Max. Traction Force, Test no.5 . . . . 131

F18. 4.49 Change in Max. Traction Force, Test no.17 ..... 132

F1g.'4.50. Change in Max. Traction Force, Tesṫ no.2 ..... 133

F1g. 4.51 Change in Max. Traction Force, Test no.14 ..... 134

F1g. 4.52 Change in Strip Stress v8, Borfzontal Load Component 135

F1g. 4.53 Change In Strip Stress v8. Horizontal Load Component 136

F1g. 4.54 Change in Strip Stress vs. Horizontal Load Component 137

F18. 4.55 Change In Str1p Stress v8. Horlzontal Load Component 138

F1g. 4.56 Change 1n Strip Stress vs Horizontal Load Component 139

F18. 4.57 Change in Strip Stress vs. Horizontal Load Component 140

F1g. 4.58 Change in Strip Stress/Horizontal Load Component \

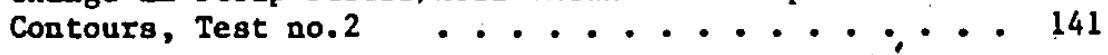

F1g. 4.59 Change in Strip Stress/Horizontal Load Component Contours, Test no.8 ............. 142

Fig. 4.60" Change in Strip Stress/Horizontal Load Component Contours, Test no.11 ........... 143

Fig. 4.61 Change in Strip Stress/Horizontal Load Component Contours, Test no.13 . . . . . . . . 144

Fig. 4.62 Change in Strip Stress/Horizontal Load Component Contours, Test no.15 . . . . . . . . . 145 


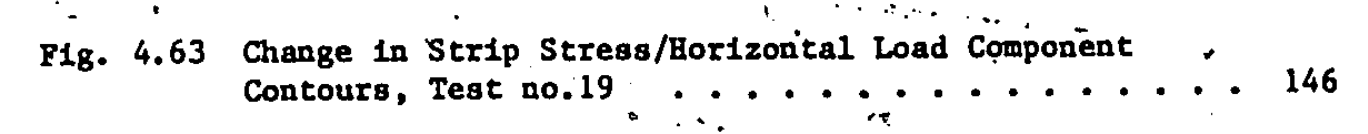

F1g. 4.64 Change in.Str1p Stress/Hor1zontal Load Component
Contours, Test no.1 . ......... 147

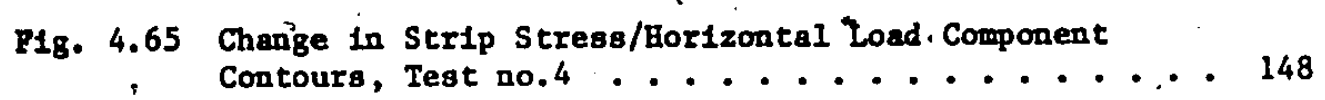

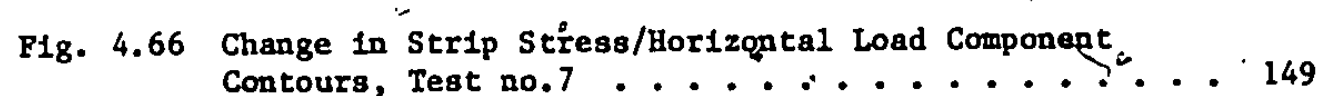

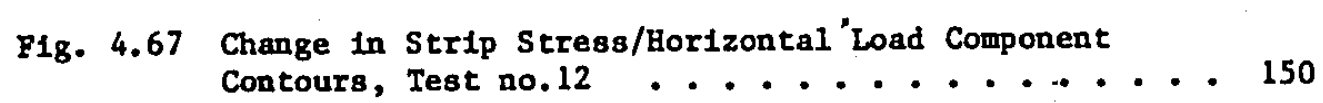

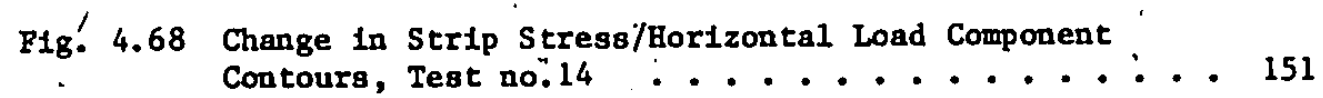

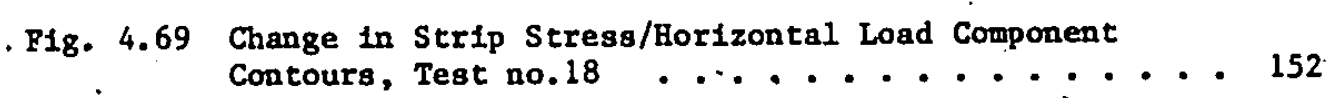

F18. 4.70 Wall Defleçtion, Hortzontal Load Component, 'Test no.2 153

F1g. 4.71 Wall Deflection, Hor1zontal Load Component, Test no.11 154

Fig. 4.72 Wall Deflection, Horlzontal Load Component, Test no?15 155

Fig. 4.73 Wall Deflection, Hortzontal Load Component, Test no.19 155

F1g. 4.74 Wall Deflection, Horizontal Load Component, Test no. 1 - 156

F18: 4.75 Wall Deflection, Horizontal Load Component, Test:no.4 157

F1g. 4.76 Wall Deflection, Horlzontal Load Component, Test no.12 158

P1g. 4.77 Wall Deflection, Horizontal Load Component, Test no.18 158

F18. 5.1 Partition of Active and Resistant Zones; 2:1 Load

Dispersion Configuration ............. 159

F1g. 5.2 Free-Body Dlagram of Strip Portion ........ 159

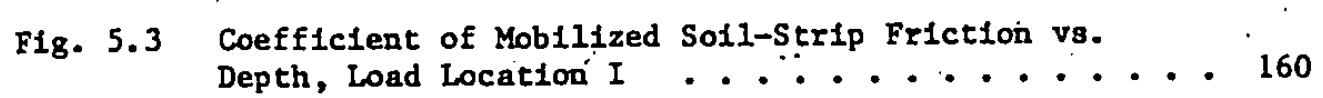

F1g. 5.4 Coefficlent of Mobilized Soll-Strip Friction v8. . . . . . . 161

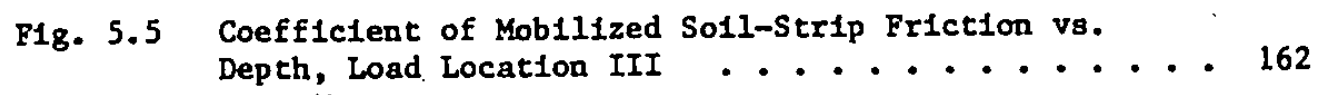

F1g. 5.6 Coefficient of Mobilised.Soti-Strip Friction v8.

Depth, Load Location IV ........... 163

$$
-\mathbf{x}-
$$


F1g. 5.7 Distribution of Max. Traction Force (theoretical)

with Dep̂th, Load Location I ............... 164

Fig. 5.8 Distribution of Max. Traction Force (theoretical)

w1th Depth, Load Location II ......... 165

P1g. 5.9 Distribution of Max. Traction Force (theoretica1)

with Depth, Load' Location III .......... 166

F1g. 5.10 Distribution of Max. Traction Fofce (theoretical)

with Depth, Load LocatIon IV .......... 167

P1g. 5.11 Comparison Between Experimental and Theoretical

Values of Max. Traction Porce ........ 168 .

F1g. 5.12 Comparison Between Experimental and Theoretical

Values of Max. Traction Porce ......... 169

F1g. $5.13^{\circ}$ Comparison Between Experimental and Theoretical

Values of Max. Traction Force ......... 170

170

F1g. 5.14 Comparison Between Experimental and Theoretical

Values of Max. Traction Force ........... 171

F1g. 5.15 Unit Cube of Reinforced Earth . . . . . . . 172

F1g. 5.16 LateraI Soll.Stress/Horizontal Load Component

Contouŗs, Test no:2 ................. 173

F1g. 5.16 Lateral Soll Stress/Horizontal Load Component

Contours, Test no.8 ............... 174,

F1g. 5.16 Lateral Soil Stress/Horizontal Load Component
Contours, Test no.11 . . . . . . . . . 175

F1g. 5.19 to $5.21{ }^{\circ}$ Values of Lateral Soll Stress/Hortzontal Load

Componënt Rat1os; Test nos.2,8,11 ........ 176

F1g. 5.22 Lateral Solil Stress/Borizontal Load Component

Contourd, test no.1 :............. 177

F1g. $5.23^{\circ}$ Lateral Soll Stress/Horizontal Load Component

Contours, Test no.12 .............. . 178

F1g. 5:24 Infinfte Horizontal Strip Load on Semi-Infinite

Elastic Medium . . . . . . . . 179

F18. 5.25 Dimensionless Solution to Equation 5,9 . . . 179 


\section{LIST - OF TABLES}

$c^{\prime}$

Table 3.1 Loading Schedule for Experimental Programme .... 181

Table 4.1 Values of Strip Stress for Test no.1 _...... is2

Table 4.2 Values of Strip Stress for Test no.2 . . . . . . 183

Table 4.3 Values of Strip Stress for Test no.3 . . . . . . 184

Table 4.4 Values of Strip Stress for Test no.4 . . . . . . 186

Table 4.5 Values of Strip Stress for Test no.5 . . . . . . 187

Table 4.6 Values of Strip Stress for Test no.6 ......... 188

Table 4.7. Values of Strip Stress for Test no.7 $\ldots$. . . . . 189

Table 4.8 : Values of Strip Stress for Test no.8 . \. . . . 190

Table 4.9 Values of Strip Stress for Test no.9 . . . . . . 191

Table 4.10 Values of Strip Stress for Test no.10 . . . . . . 192

Table 4.11 Values of Strip Stress for Test no.il . . . . . . 193

Table 4.12 Values of Str1p Stress for Test no.12 . . . . . . 194.

Table 4.13 Values of Strip Stress for Test no.13 $\quad$. . . . . . 195

Table 4.14 Values of Strip Stress for Test no.14 . . . . . . 196

Table 4.15 Values of Strip Stress for Test no.15 ? . . . . 198

Table 4.16 Values of str1p Stress for Test no.16 . . . . . . 199

Table 4.17 Values of Strip Stress for Test no.17 . . . . . . 200'

Table 4.18 Values of Strip Stress for Test no.18 $\ldots . . . . . . .201$

Table 4.19 Values of Strip Stress for Test no.19 . . . . . . . 202

Table 4.20 Wall Deflection Readings, Test no.1 . . . . . . . 203

Table 4.21 Wall Deflection Readings, Teat no.2 . . . . . . . 203

+ Table 4.22 Wall Deflection Readings, Test no.3 . . . . . . 204

Table 4.23 Wall Deflection Readings, Test nó.4 . . . . . . . 204 


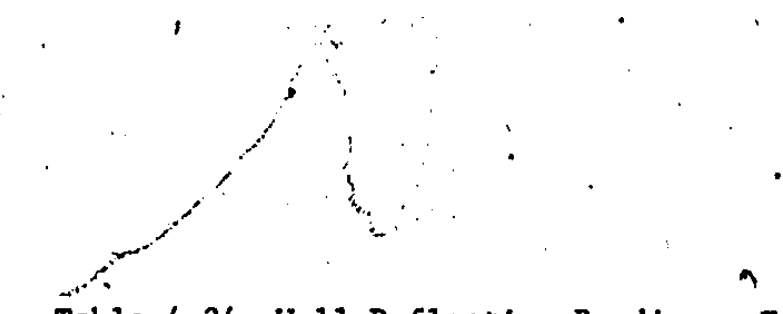

Table-4.24 Wall Deflection ReadIngs, Test no.5 . . . . . . . . 205

Table 4.25 Wall Deflection ReadIngs, Test no.6 . . . . . . . 205

Table 4.26 Wall Deflection Readings, Test no.8 . . . . . . . 206

Table 4.27 Wall Deflection Readings, Test no.9 . • : . . . . , 206

Table 4.28 Wall Deflection Readings, Test no.10 . . . . . . . 207

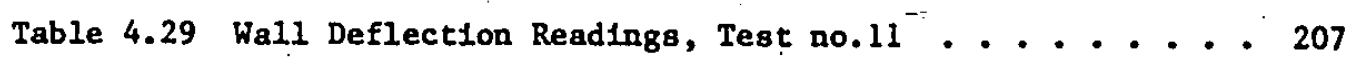

Table 4.30 Wail Deflect1on Readfng8, Test no.12 . . . . . . 208

Table 4.31 Wall Deflection Readings, Test no.13 . . . . . . . 208

Table-4.32 Wall Deflection Readings, Test no.14 ..... . . . 209

Table 4.33 Wall Deflection Readings, Test no.15 . . . . . . . 209

Table 4.34,Wall Deflection Readings, trest no.16 . . . . . . . 210

Table 4.35 Wall Deflection ReadIngs, Test no.17 ......... 210

Table 4.36 Wall Deflection ReadIngs, fest no.18 . . . . . . . . 211

Table 4.37 Wall Deflection Readings, Test no.19 ......... 211

Table 4.38 Average Values of Strlp Elongation $\quad . . . . . . . .212$

Table 5.1 Calculated Values of Soll-Strip Friction

Coefficlent ................... 213

Table III.1 Values of the Stress-Strain Ratio for the Strain Gauges .................... 215

Table III. 1 Values of the Stress-Strain Rat1o for the Strain Gauges on the Replaced Strips . . . . . . . 215 
Symbol

A

b

c

$\mathrm{c}_{\mathrm{u}}$

d.

$\mathrm{n}_{10}$

$\mathrm{D}_{50}$

$\mathrm{D}_{60}$

dh

ds

$\mathrm{dT} / \mathrm{dl}$

e

$E_{t}$.

$E_{t}$

f

fo

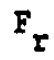

h

H

k

$\mathrm{K}_{\mathrm{a}}$

$\mathrm{R}_{0}$

$\mathbf{R}^{\prime}$

\section{NOMENCLATURE}

Represents

Cross-sectional area of backfili, reinforcing

strips, (Kennedy et al.,(16)).

Width of relnforcing strips.

Soll Cohesion.

Coefficlent of uniformity.

Distance from wall face to surcharge load, (F1gs.2.9,2.11)

Diameter at which $10 z$ of the solt is finer.

Diameter at which $50 \%$ of the 8011 is finer.

Dlameter at which $60 \%$ of the soll is finer.

-Hortzontal spactng of the reinforcing strips.

vertical spacting of the relnforcing strips.

Slope of tension distribution curve along strip.

Eccentrictity of surcharge load.

Tangent modulus of so11 backf111, (Duncan, (10)).

Tangent modulus of relnforcing strips, (Dunçan,(10)).

Coefficlent of soil-strip friction.

Coefficlent of soll-strip friction as determined from a shear shear box test, (Bacot et al., (4)).

Frictional resistance of strip, (Lee et al. ,(7)).

Depth below surface.

Horlzontal load component.

Coefficlent of lateral earth pressure.

Coefficlent of active lateral earth pressure.

Coeffictent of at-rest. lateral earth pressure.

Modulus number, (Duncan, (10)). 
$\therefore$

Length of reinforcement effective in resisting pull-out of the strips.

Bxponent determining rate of variation of Initial tangent modulus with $\sigma_{3}$, (Duncan, (10)).

$\mathbf{P}$

Point load on surface.

$\mathbf{P}_{\mathbf{a}}$

Actlve earth pressure agalnst vertical retalning wall.

P.

At-rest earth pressure.

q

Vertical load component.

$\mathbf{R}$

Reduction factor, (Kennedy et al.,(16)).

$\mathbf{R}_{\mathrm{f}}$

$R_{1}$

$R_{2}$

$T_{\max }$

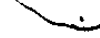

Pałlure rat1o, (Duncan, (10)).

Scalar, (Fig.5.24).

Scalar, $(\mathrm{F} 18.5 .24))$.

Maximum strip traction force.

$\Delta \mathbf{T}$

Increment in strlp traction force.

$$
\text { - GREEK - }
$$

a

Angle, (F1gs.2.10, 5.24).

Angle, (F1g.2.10).

Unit weight of soll.

Angle, - (F1g. 5.24).

= 3.1415926535897 .

Mafor principal stress.

Minor principal stress.

Vertical, stress.

Horfzontal stress.

$\sigma_{\mathcal{H}}$

Vertical stress at fallure.

Incremental vert1cal stress.

$\Delta \sigma_{v}$

$\Delta \sigma_{\mathrm{H}}$

Incremental horizontal stress. 


$\Delta \sigma_{\mathbf{8}}$
$\tau$
$\phi$
$\psi$

Inciremental strip stress.

Shear stress acting on strip.

Internal angle of friction of the soll.

Angle of soil-strip friction. 
1

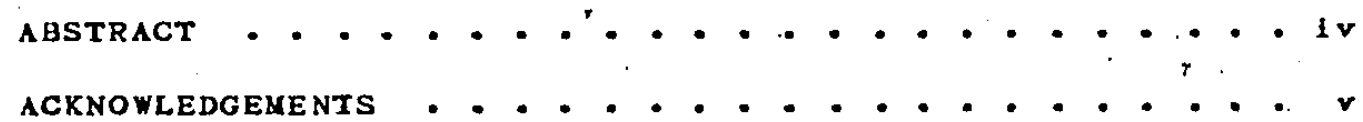

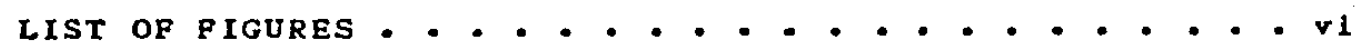

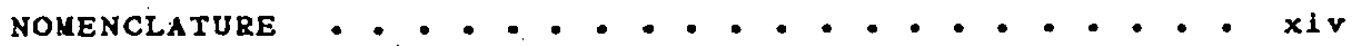

Chonter

Rata

General . . . . . . . . . . . . . . . . . 1 Objective . . . . . . . . . . . . . . . . 2 scope .. : . . . . . . . . . . . . . . . 3

I. BACKGROUND AND LITERATURE REVIEW • • • • • •... • 4

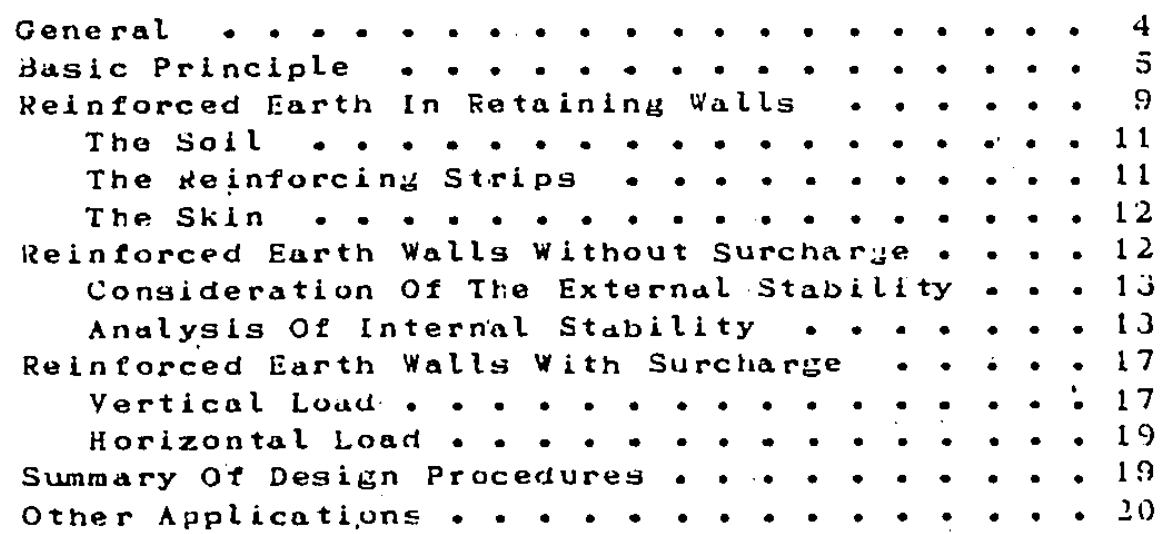

II - EXRERIMENTAL INVESTIGATION • • - • • • . . • • 22

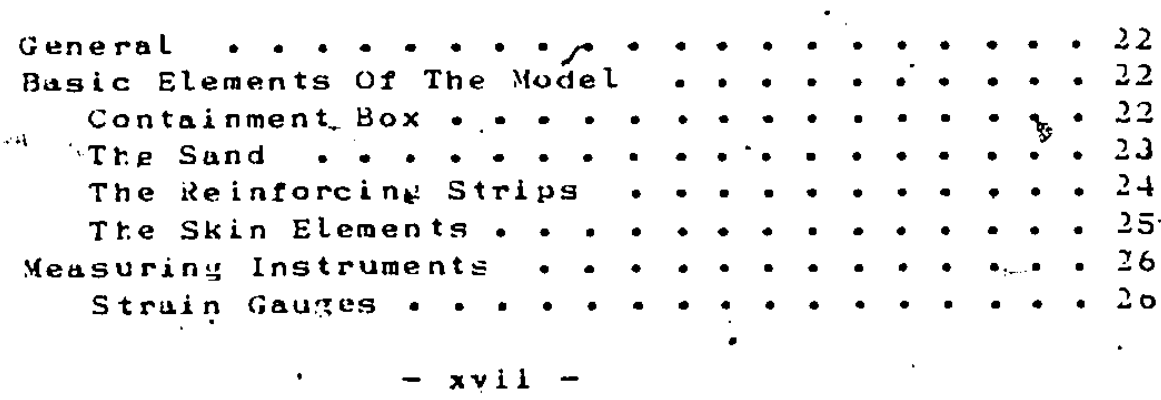




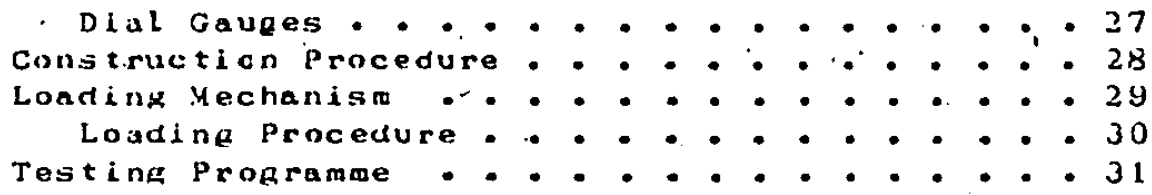

IV. PRESENTATION AND DISCUSSION OF EXPERIMENTAL RESULTS 34

Introduction..................... . 34

Traction Force Distribution in the Strips Under

a Vertical Loading... . . . . . . . j5

Load Applied at Various locations..... . . 30

Location of The Failure plane . . . . . . . 42

Maximum Traction Force as a Function ot Depth .44

Behavlour of the Wall Face.......... . . 40

Effect of Horizontal Component on rraction force

Distribution................48

Horizontal Component Directed Tuwards the

Wall face............... 49

Ulorizontal Component Virected Away from the

Wall Face... . . . . . ...... 51

Effect of llorizontal Corponent on Location of

the Failure Plane .... . . . . . 53

Effect ot Horizontal Component on Vaximum strip.

Traction Forces ... . . . . . . . 53

Horlzuntal Comfonent Directed Towards the

Vall face... ............. . 54

Horizontul Component Directed Away from the

Hall Face. . . . . . . . . . . 54

Overall Change in Strip Traction Force due to

Jorizontal ccinfonent... . . . . . . 55

Horizuntal Component Directed Towards the

Wall Fuce... . . . . . . . . . 57

Horizontal Component Directed Away Fron the

Wall Face.............. 53

Effect of Horizontal lonponent on jehaviour of

Hall Face... . . . . . . . . . . b1

V. INTERPRETATION OF RESTLTS • . . . ... . . . . . 63

Mobilized sonil-Strip Friction . . . . . . . 63

Maxinuin Traction Force as a Function of Depth 06

Stresis Distribution dise to Horizontal Load

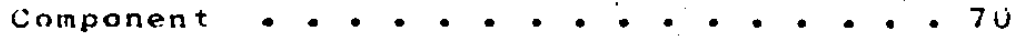

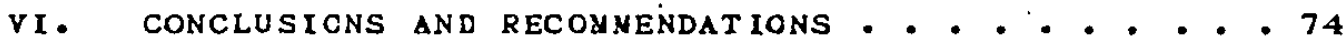

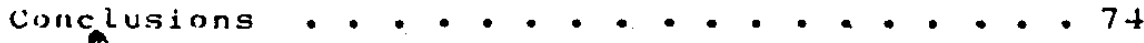

Recdinenuations for further Kesearch... . . 76 
Chapter I

INT RODUCT ION

\subsection{GENERAX}

- The use of tensile stress resisting material in the torm ot fibres, straps, barg or boards in combination, witn soil has been in use for thougands of yeurs, from rope tibrey dnd bambou shoots around which mud wallis have been built, to the more familiar, and still current use ot tree trunks in corduroy roudis.

It was not until the $1960{ }^{\prime}$ s that, this aje old concest bejan to be analysed and put to use in overcoming geotechnical problems, which would otherwise have reculred costly sulutions.. Vidal(29), a French engineer, working̈ alonf̧, pioneered the use of flexible reinforcinis elements to improve the strength characteristics of sind. The association of the two inaterials resultad in a cohesive inaterial he terned "liainforced Earth".

Reinforced earth has since been used in foundation impruvement, slope stability improvement and d variety of other situitions, however its most widespreal and best known use is in a retaining wall situation. Much research has bern carried out into the behaviour mechanisin of the reintorrets earth retainins wall, and the most valuable work has iseen 


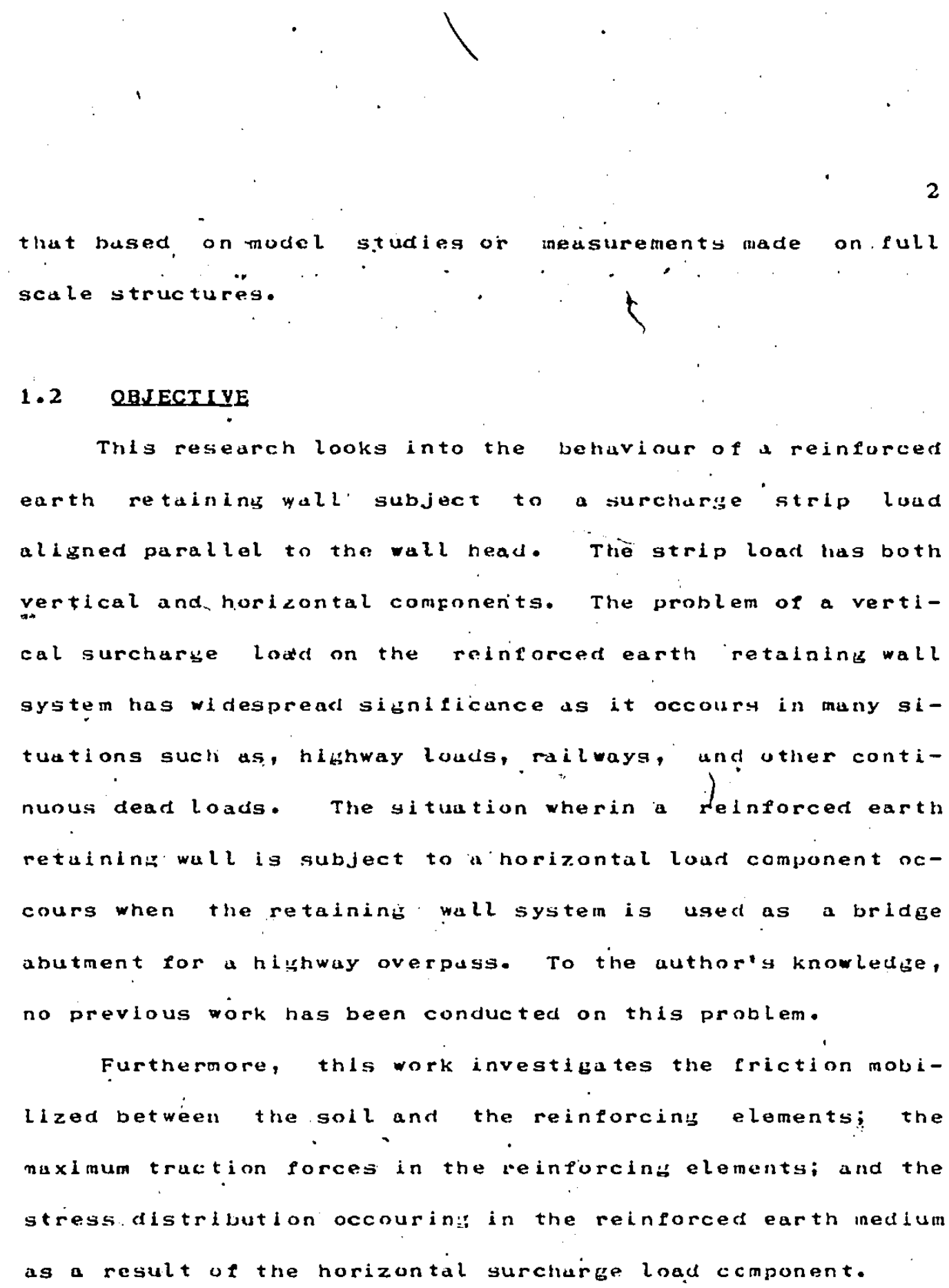


1.3 SCOPE

In order to invegtigate the above ispects of the behavlour of the reinfurced earth retaining wall system, extensive testing was done with a reinforced earth wall nodel. The model consisted of a Lake Erie beden sund backfill, riinforced with strips of metal, roughened to increase the triction between the sand and the strips. The strips were connected to the wall facing. which was composed of thin steel channels. Some of the reinforcing strips were instrumented wi th strain sulges to recurd the strain developed in the strips due to the surcharge lóde. The deflection of the wall face was also monitored by diul gauges. Both the vertical and horizontal surcharge loads were applied through a mechánical loading apparatus set up about the murlel.

Results of this experimental work were analysed and used to explain the behaviour mechinism of the reintorced earth retaining wall system.under the various lnading conditions. These results were compared with design procedures currently in use for u'reinforced earth retaining wall under a surchurge strip loading condition.

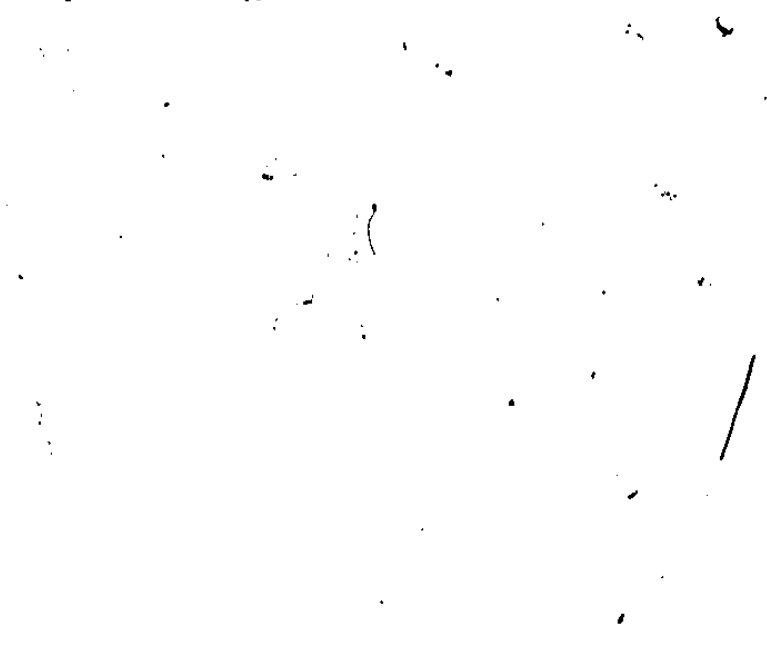




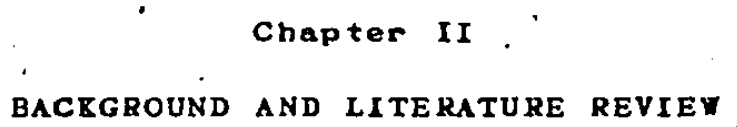

\subsection{GENERAL}

This chapter introduces the principle of reinforced earth, and highlikhts the cörceppts tundamental to an appreclation of its behaviour, ahd shers. light upon a common misconception that reinforced earth walls operate upon a "tie-backlormechanism. In additicn, prouressin the developenent of experimental and theoretical achievements in the case of the reinforced) earth wall with and without a surcharge is summarized. A. brief note on current desinn procedure is also included, which the readerwill appreciate, is quite empirical, and is derived predominantly from experimental data ruther than theoretical considerations.

Hries mention is also macie of computer modeling of the reinforced eurth wall, and attempts to describe the behaviour of reinforced edrth ws. an. ideal material in terms or almathematical model. 


\subsection{BASIC RRINCIRLE}

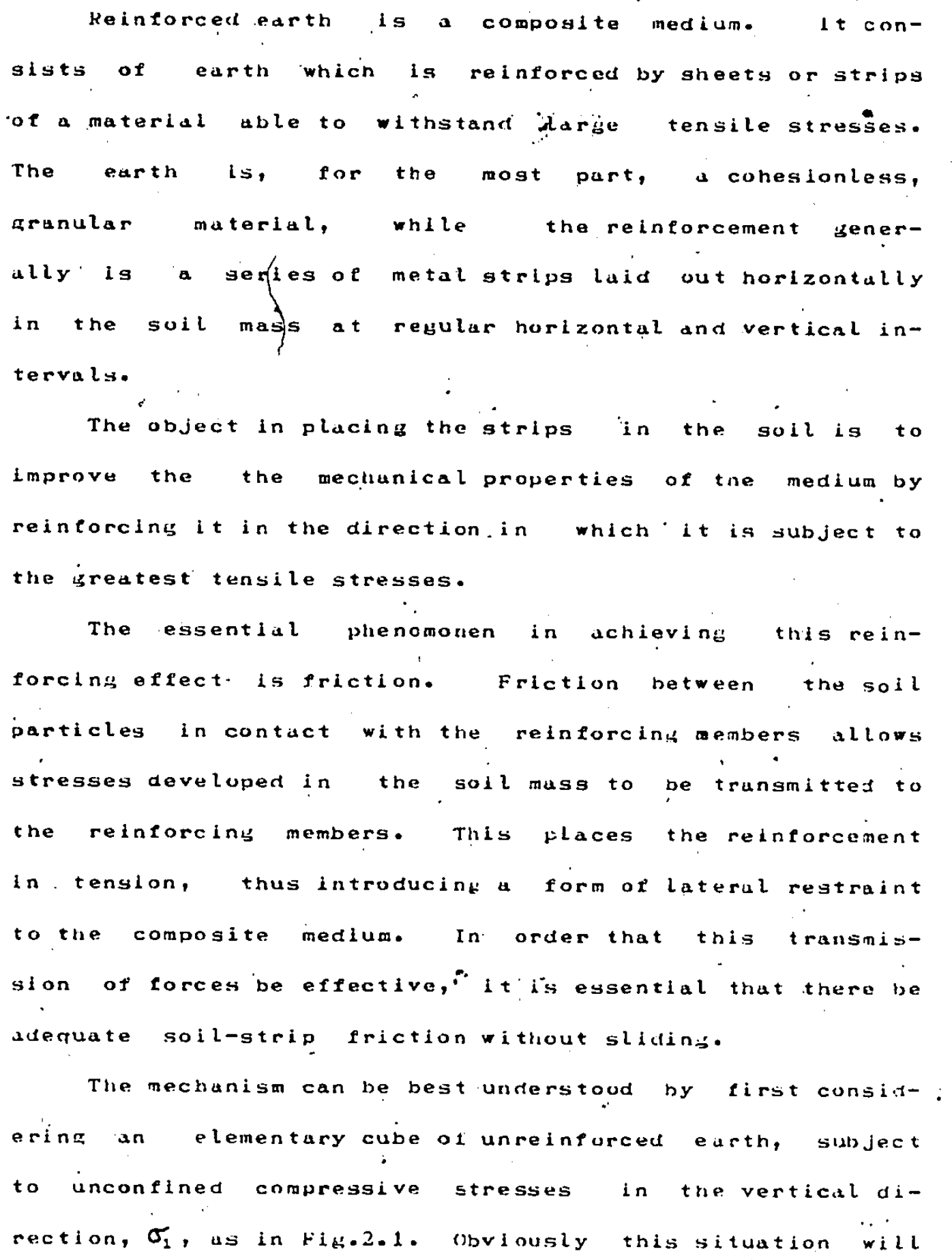




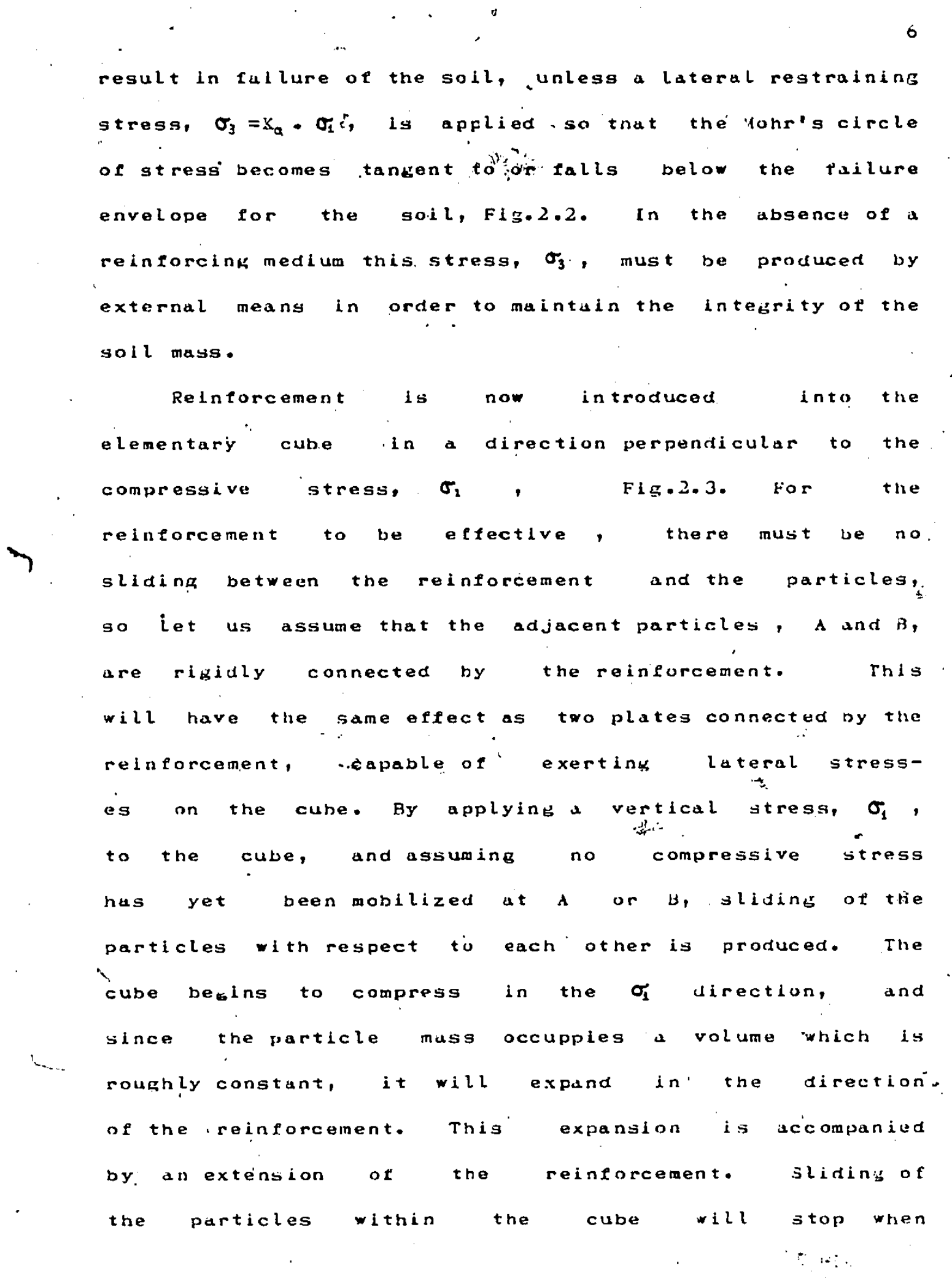




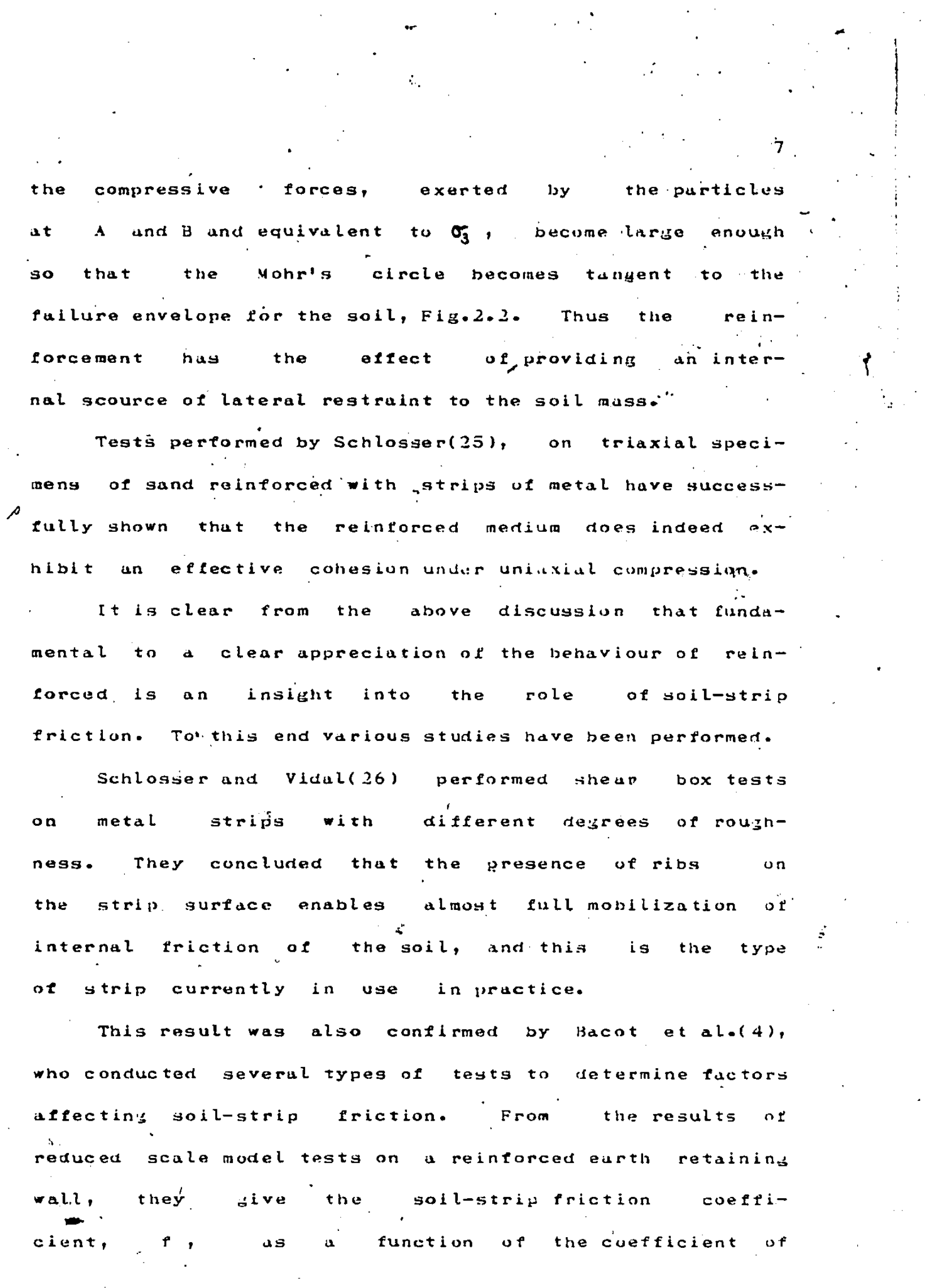




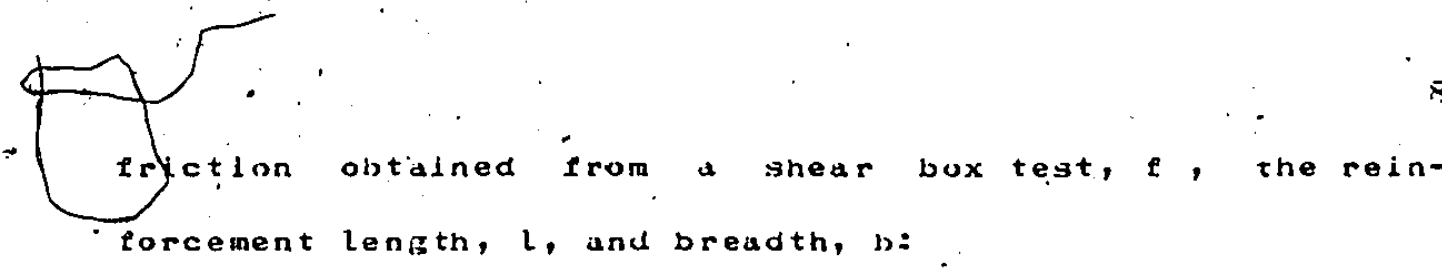

forcenent length, $l$, and breadth, b:

$$
\therefore \quad \cdot p=c_{0}+\alpha 1+\beta / b
$$

with $\alpha$ and $\beta$, constants.

This relationship was verified by Schlosser und Elias(24), who. also looked ot, the effects. of density and overburden pressure on the friction coefficlent. In particular they noted that tangential stresses exerted by reinrorcement on a dense soll will cusse the soil to dilate, which causes an increase in the normal stresses on the reinforcement, resulting in a higher value of soilstrip friction. They also noted that the friction angle will decrease. With increasing overburden pressure. Assuming the coefficient of friction to be related to the ratio $\left(\sigma_{v} / \sigma_{v_{f}}\right)$ where $\sigma_{v}$ is the existing vertical stress and $\sigma_{v_{f}}$ is the vertical stress at eailure, Kennedy et al. (16) proposed the following relationship for the friction coeffecient:

$$
P=\left(\sigma_{r} / \sigma_{f}\right) \cdot \tan \psi
$$
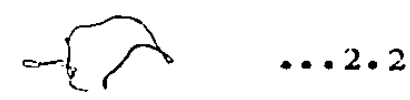

where $\Psi$ is the angle of soil-strip friction, and tue ratio $\left(\sigma_{v} / \sigma_{v_{f}}\right)$ may he taken as (1/fuctor of safety). The values currently In use in the design of rein-

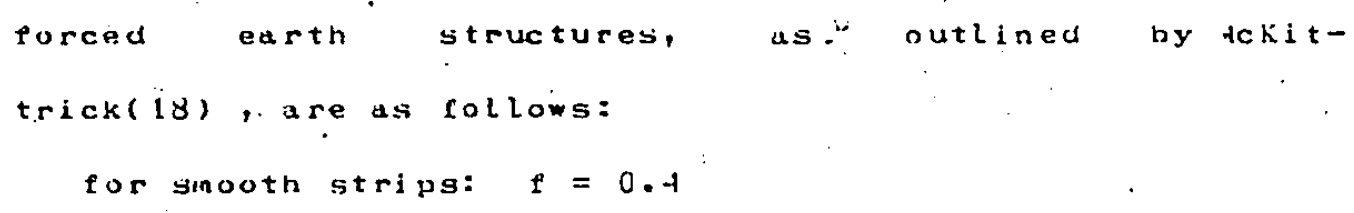




$$
\begin{aligned}
& \text { for ribbed strips: } f=\tan \phi, \quad \text { for } h \geq 0 m \\
& \qquad f=f_{0}+(h / 6)\left(\tan \phi+t_{0}\right) \text {, for } h \leq b m \quad \ldots 2.3
\end{aligned}
$$

where $\phi$ is the angle of internal priction of the soil, $n$ is the depth below the surface. The coefticient $f_{0}$ depends upon a numbert ot parameters i angularity, surface texture, anzle of internal friction). it may be expressect as fullows:

$\therefore \quad . \quad \ldots=1.2+204 C_{2} \quad \ldots 2.4$

where $C_{4}$ is the coefficient of uniformity $=D_{\infty} / u_{10}$, where $D_{\infty}$ and $D_{10}$ are the diameters at which $60 \%$ and $10 \%$ respectively of the soil is finer, by weight.

\subsection{REINEORCED EARTH LN RETAINING WALLS}

Oae of the widest applications of the reinforced earth system is ln retaininio wals. As has alreaciy been made clear, reinforced eurth possesses an effective cohesion in the direction in which the reinfurcing elements lie. This makes it an ideal material for use in a retuining wall gituation.

Considering a semi-infinite cohesionless soil muss With a horizontal surface behind a rigid non-moving retaining wall, Fig.2.4, the pressure, P, exerted uy the wall on the soil at any deisth, h, in order to maintain the soil in the atrest condition, is given by:

$$
p_{0}=z_{0} \cdot r \cdot n
$$$$
\therefore 2.5
$$ 


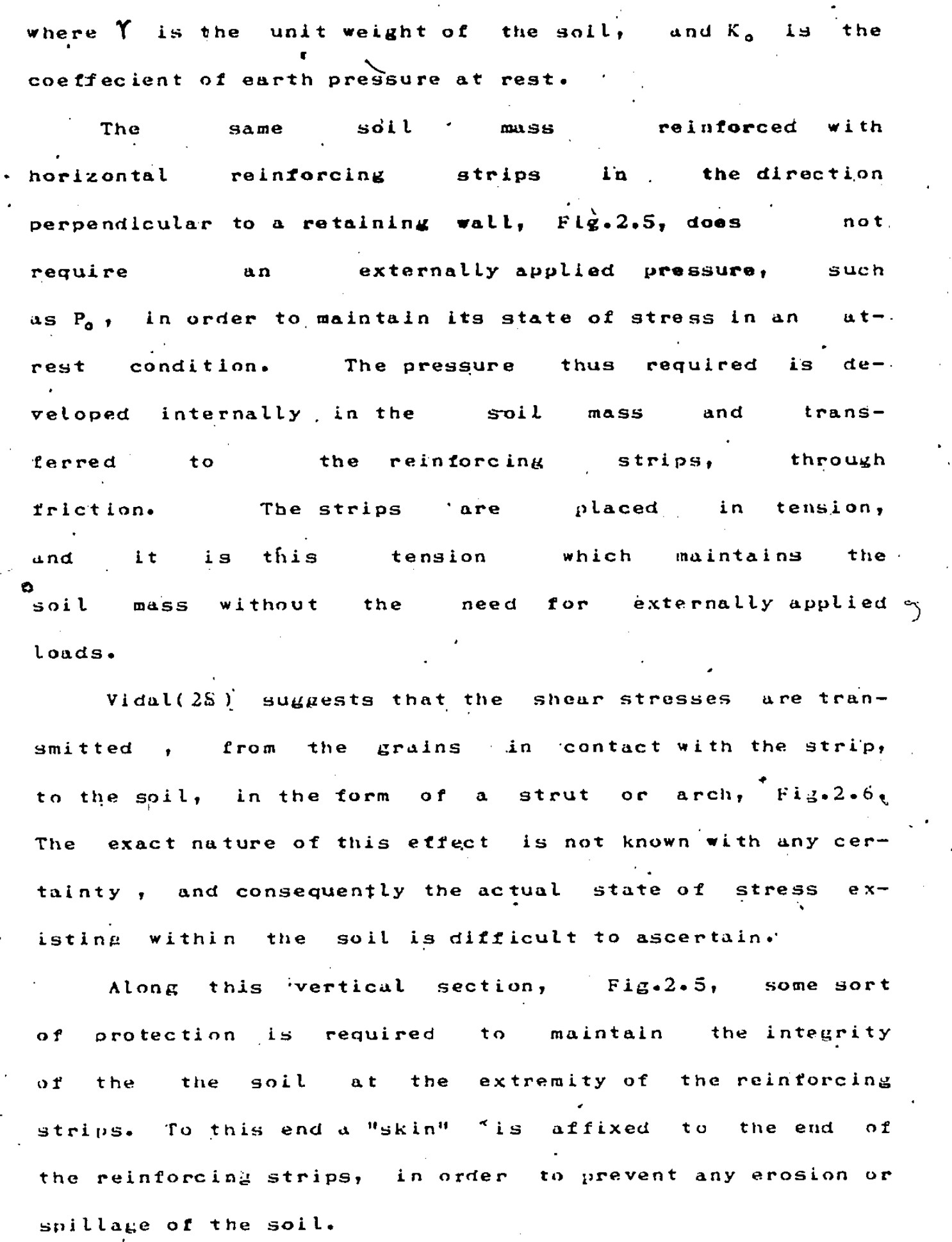




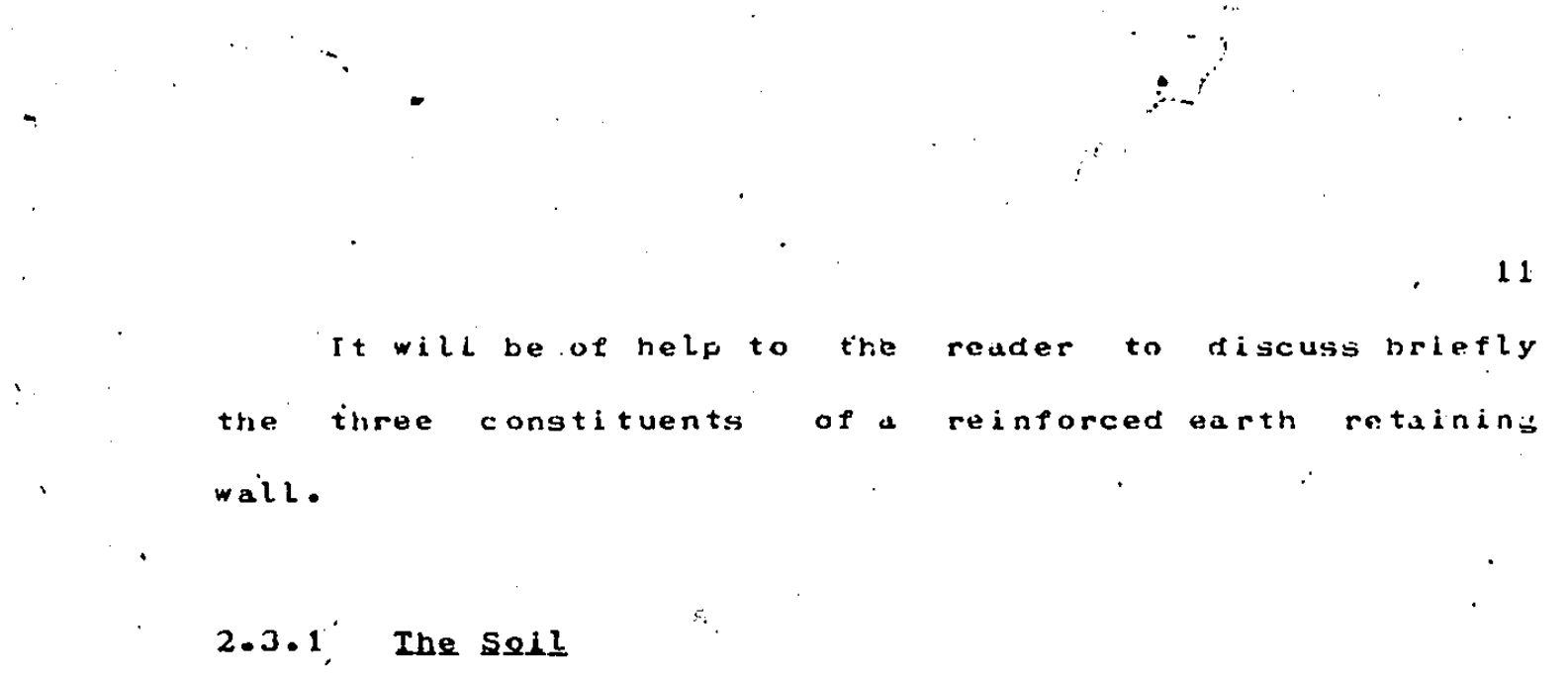

\section{T.}

The type or soil used is a preedraining granular material. there are two reasons for this:
1. To prevent any bulla-up of pore water pressure in the backfill which would reduce, the shear strentith of the soll.
2. To enable an uppreciable amount of friction to be ideveloped between the soil and therein- forcing strip.

Current desiun specifications recomend that 25 is be the maximum percentage by weight of the backfill material passinis the no.200 (.074: mm openinis) sieve size. In all cases the soils used are classiried as non-plastice the esect of clay content his ben considered elsewhere $(18)$.

\subsubsection{The Relnfercing stivis}

These are made of balvanized steel and are usualLy'ribbed in order to increase the soil-strip friction. The design yield stress is taken as two tniris of the actual yiela stress as determined experimentally. Galyanized steel is used, as when the zinc corrodes it 


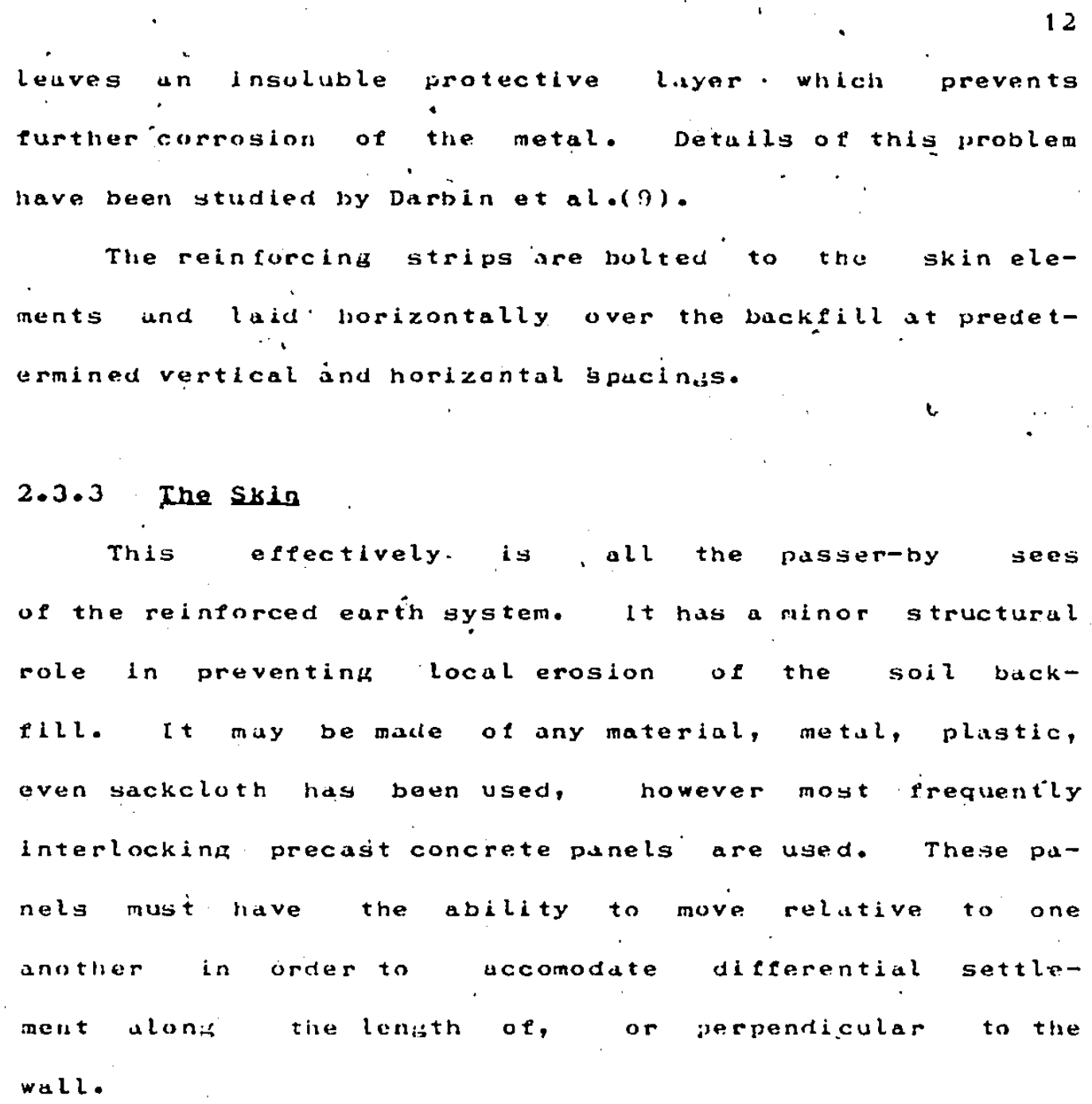

\subsubsection{The Skin}

This effectively. is, all the passer-by sees of the reinforced earth system. lt has a minor structural role in preventing local erosion of the soil backHill. It may be macle of any material, metal, plastic, even sackcloth has boen used, however most irequently interlocking precast concrete panels are used. These panels must have the ability to move relative to one another in order to accomodate differential settlement ulonif tine lenith of, or jerpendicular to the wall.

\subsection{BEINEORCEED EARTH MALIS YITHOUT SURCHARGE}

In diulin:s with the stability of": the rein-
forced earth wall structure there ure two basic prob-
lems.




\subsubsection{Cengideration of The External Stability}

The overull dimensions ot the structure must be considered a long with any external loading conditions, Fig.2.7, to determine the degree of settlement and factor of safety against overturning, bearing capacity pailure and sliding.

Details of this analysis will, not be considered herein.

\subsubsection{Analysis ef Internal stapility}

This is the aspect of seinforced earth which has received most attention from regearchers, as the exact behaviour of a reinforced earth wall is very complex, and many of the rechanisms are us yet still not fully understood. However, reingorced earth retuining wallo have been built for almost fifteen years and successful design procedures huve been tormulated basea on simplifications and selection of conservative parameters.

Since vidal(29) introduced the concept of reinfored earth for retaining wals, researchers have been consigtent in describing the predominall failure inodes:

1. Fallure due to lack of tensile strength of the reinforcins strips.

2. Failure due to insufficient soil-strip triction, i.e. slippaze of the reinforcini strips. 
14

3. Breskdown of the so-called arching effect, lis.2.6, 1.e. Sheur failure of the cranular matrix between trie strips. This type or failure nup been studied elsewhere by shen et al. $(27)$.

Lee et al.(17), recognized the significance of the above fallure modes and interpreted the mechanism of faiLure in terms of Rankine earth pressure theory. They ussumed an active eurti pressune distribution on the wall face, and that the maximum tie tension, $T_{\max }$, at any depth, $h$, below the surface is given by:

$$
T_{\max }=R_{a} \cdot Y \cdot h \cdot d s \cdot d h \quad \cdots \cdot 2 \cdot 6
$$

where ds and ih are the vertical and durizontal spacints of the relnforcing strips, and $k_{a}$ is the coefficient of active earth pressure. They also assumed that the maximum tension in the strip occours at the wall face. on the basis that an active fallurezone had been formed, the reinforcing strips vere assumed to offer resistance against pull-out only in the soil mass beyond the failure zone tefined by the angle $\left(45^{\circ}+\phi / 2\right)$. Thus tho trictional resistance, Fr, of a strip at any depth, $\dot{b}$, helow the surtace:

$$
F_{r}=2 \cdot b \cdot L_{e} \cdot h \cdot r \cdot \sigma_{r}
$$

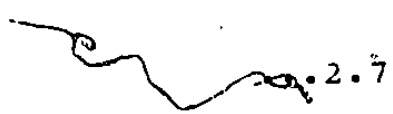

where le is the length of the strip beyond the fuilure zone, i.e. the lenuth of the reinforcement effective in reaisti nes pull-out. 


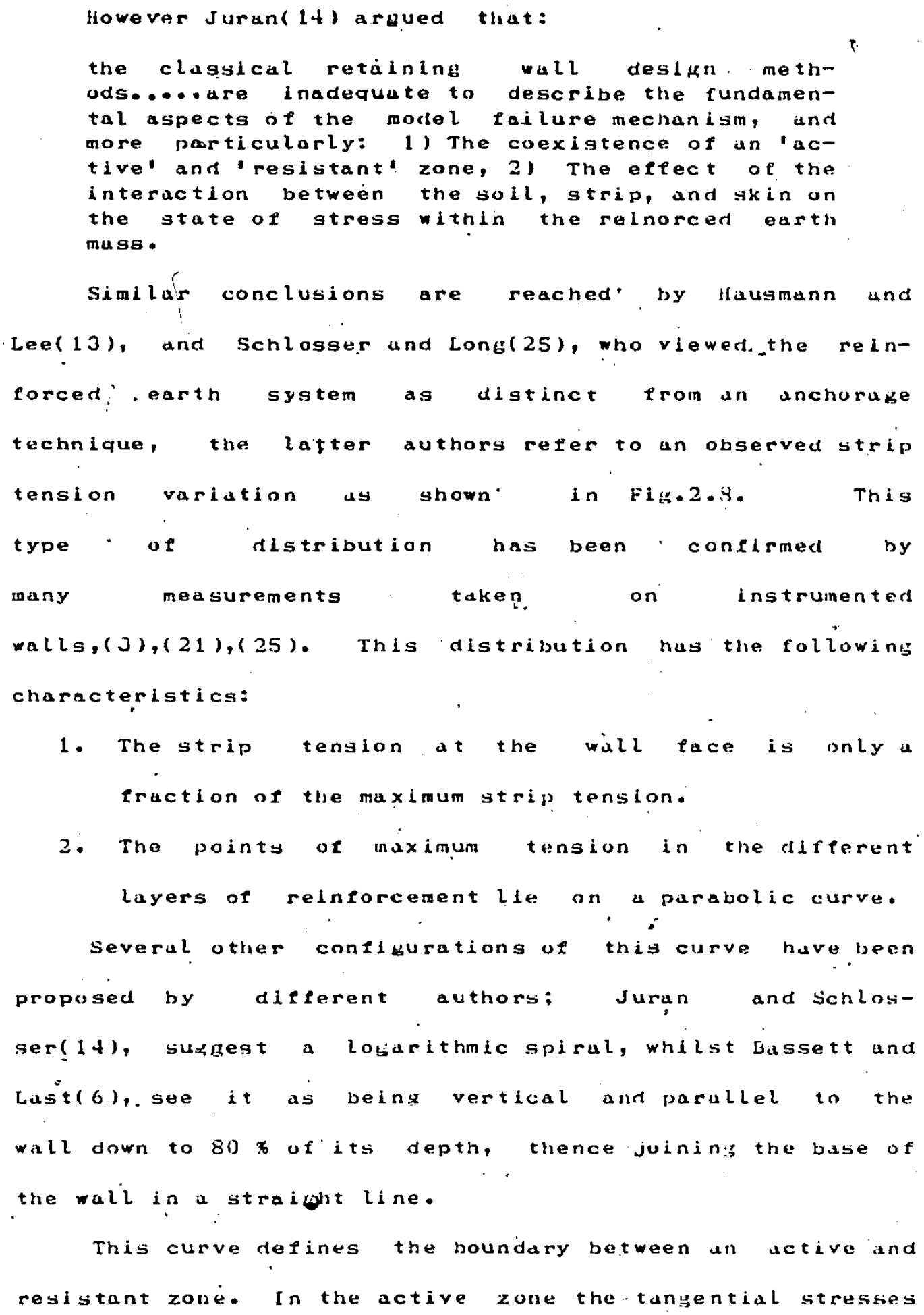


exerted by the earth un the reinforcement are directed towards the wall, Fif.2.8,. whilst in the resistant zone they are directed away from the wull, arid here the earth tends to retain the reinforcement.

The tangential component, $\tau$, of the stress exerted by the earth on each ruce of the relnforcing strip is:

$\tau=(a T / d L) / 2 \cdot b$ $\cdots \cdot 2 \cdot 8$

where $f T / d L$ is the slupe of the tension curve. schlosser also sugigesteid thict in the active zone the cuerficient of eriction moblizized along the relnforcement was close to the actual value of fully mobilized soil-strip friction. based on results from an instrumented full-scule structure, shen et al. (27), proposed that the state of stress in. a relnforced earṭ wall approaches the at-rest condition. This was alsio suggested by Chang and forsyth( $)$ ). However more extensive field observations made by Buquelin( 5 ), indicate that the coefficient k near the surface is closer to, $k_{0}$, decreasing to a value sigaller than $k_{a}$, over a depth of 6 netres, Fig.2.14. Juranetal.(15) also reach a similar conclusion.

A Pintẹ element approach was also considered by $A$ Hussaini and Perry( 3$)$, assumint a hyperbolic stress-strain behaviour fof the earth fill and assuming the behaviour of - the reinforcing strigs and facing elements to be lineur elastic. Larison and Gerrard(11), sugaest considering the 


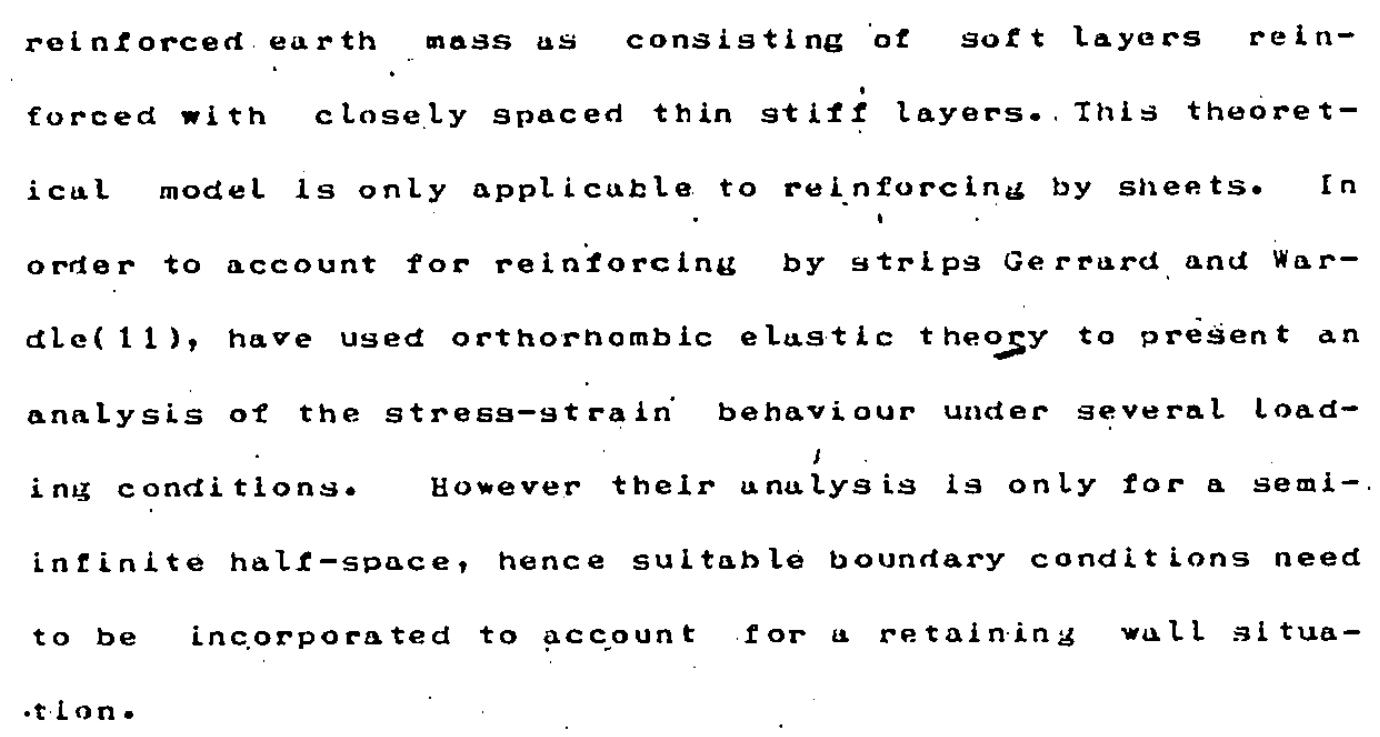

\subsection{BELNEORCED EARIH YALLS WIH SURCHARGE}

In many instanges the reinforced earth structure will be built to suppourt an imposed load, such as in the cuse of njorhays, railroads, and mosit erequently, bridige abutments.

\subsubsection{Yertical Lead}

The effect of a vertical load is to increase the tension in the reinforcementg, by increusing the vertical stress throubhout the soll mass. Measurenents made on models(21), and on a tull scale structure in Dunkirk, France( 5 ), have shown that the additional vertical stress is spread in the seinforced earth mass at a slope of $2: 1$. Schlosser and Long(25) reported un theoretical and experimental work conducted on the effect of a line trad acting on trie head of a reinforcer eurth retaining wall and 
parallel to it. They also assumed the load to disperse as a uniform gtress within the $2: 1$ dispersion lines, Fip.2.9. The additional tension in the reinforcement, $\Delta T$, induced by the surchage effect, was uiven by:

c

1

$$
\Delta T=K_{a} \cdot d s \cdot d h \cdot(P /[d+h / 2]) \quad \cdots 2 \cdot 9
$$

However this analysis is still baged on the Rankine coefficlent of active earth pressure, and as such is not truly representative of the reinforced earth.medium. Al-Hussaini and Perry(3), carried out a field test on an instrumented rein' forced earth wall subjected to a surcharge load unitormly distributed over the surface. They also dssuned the behav- iour of the system to follow Rankine earth pressure theory, which led to a lack of agreement hetween the experimental and theoretical results.

- Kennedy et al.(16), present an analysis to estimate the maximum tension in the relnforcement when the reiniorced - earth retaining wall is subjecter to. a surcharge strip load. $T_{\max }$ is deduced from a modification of Terzanitis poralua (based on elastic thenry) for the computation of the lateral

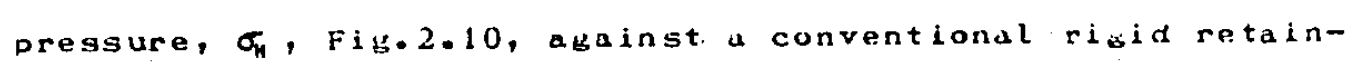
inu vall:

$$
T_{\text {max }}=(2-R) \cdot q \cdot 0^{\prime}(\beta-\sin [\beta] \cdot \cos [2 \alpha]) \cdot d s \cdot d h / \pi \ldots 2 \cdot 10
$$

where $K$ is a reduction factor based upon the gtiffness of the seperate media. 


\subsubsection{Honcizental Load}

To the knowledie of the author very linited work has been carried out to determine the effect of thorizontal surcturge load applied on the soil surface, on the hehaviour of a reinforced earth retalning wall. A trórigontal component directerl towards the wall.face can have a significant effect on the internal stability of the wall, as lt witl result in a larae increuse in strip tension in its resion uf influence. The French Ainistry of Transiort(20), huve pro' poset a methol of incorporating tnis effect into resign, which is summarized in Fis.2.11, where $\Delta \sigma_{N}$ is the change in horizontal stress due to the horizontal sureharge luad:

$$
\Delta \sigma_{h}=\mathrm{H} \cdot\left(1-\mathrm{h} / \mathrm{h}_{\mathrm{o}}\right) /\left(1^{\prime}+\mathrm{d}\right) \quad \ldots 2.11
$$

I Is the horizontal load conponent, $h$ is ijiven as a tunction of $\phi$, the internal anyle of friction or the soil, und e is the eccentricity of tre resiltant of the vertical and norizontal load component. As yet there has been no dula publisherl to suppourt this proposition.

\subsection{SUYMARY QE DESIGN RBOCEDURES}

In designily for the internal stability of reinforcerla earth retaininiz walls, two failure modes are considerer:

1. Slinpuge due to lack of adrerence betwern soil and st rip.

2. Tensile fuilure ot the rëinfurcement.. 
The factor of safety abalnst slippage should be $=1.5$, and anainst tensile failure $\geq \underset{3}{2} 25$. This is to ensure that slippage will always occour prior to tengile failure, which is a cataytrophic typo of lailure.

The factor of safety agalnst failure by lack of adherence is:

$$
\text { F.O.S. }=\left(2 \cdot b \cdot f \cdot l_{e}\right) /(k \cdot d s \cdot d h)
$$

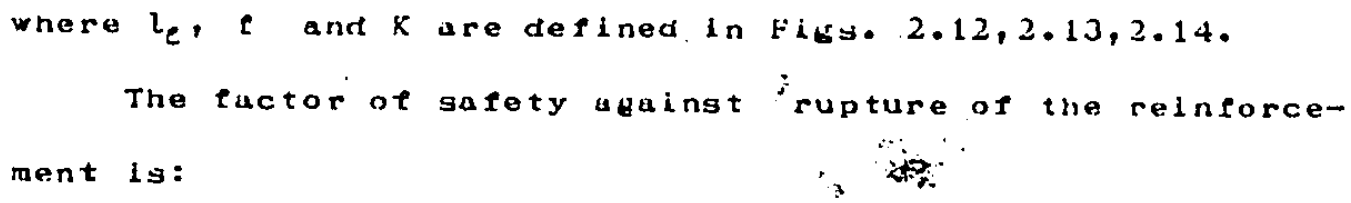

\subsection{OTHER ARPLICATIONS.}

Earth reintorcement is an extremely versatile mechanism and its applicutions are by no meang limited to a retaining wall situation with steel ties and concrete facinis panels. A significant amount of work has jeen conducted by severul resuarchers into the improvement of bearinj cajacity of 4 Iranulair medium. Binguet and Lee( 7 ), reporting on model test results from a sand reinforced witnstrips ol netal, 
indlcate that the ultimate bearinf capacity and settlement charucteristics of a soil can be improved by a factor of two to four times that of the unreinturced medium. Akinmusuru and Akinbolade( 1 ), concluded that ultimate bearing capacity values can be improved by a factor of up to three. The reinrorcing medium used in their model testswas a rope fibre material, chosen because of its suitability for low cost, projects in developing countries. Tests performed by Busett and Last(b) on sand reinforced with rods thinged with the principal tensile strain dlrections under a foutino also indicated a significant improvement in thé ultimate bearing capacity. Rea find Mitchell(23) conducted bearinir capacity tests un a sand reinforced with a grid of interconnected paper cells and concluded this method of reinforcing to be a cheap ancl effective way in improving the ultinate bearing capacity of the sand.

Fabrics are also used to improve jround cunditions for a variety of deotechnical problems. The problem of excessive ghear stresses induced at the base of a bigh embankment by. the tendency of the embankment to spread have heen sucissfully dealt with by reinforcing the critical area with woren nets of synthetic resin. Wager und Holtz( 30$)$ have also dealt with the same problem by using beams or channel sections tied together by a tie rod, at the base of the embankment, $\mathrm{Fig}_{\mathrm{g}} 2 \cdot 15$ 


\section{Chapter I II}

EXPERIMENTAL INVESTIGATION

\subsection{GENERAL}

Much of the experimental work performed on reinforced earth retaining walls has been carried out on model walls. vidal ( 29 ), recommenced the use of model tests in orcler to complement theoretical work.

The aim of the experimental work conducted was to provide a working model of the reinforced eurth retaining wall system. It must be noted.thut ithe model. was. treated as a small structure, taking into account the actuil dimensions and strerigth of the indivictual components.

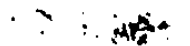
Certain elements of the model used were different than those used in actual practice, as the priority was to provide a model which in its most éssential aspects will behave as, the full-sicale structure.

.

$\therefore \quad-$

\subsection{BASIC EIEMENTS OS IHE MQDEL}

\subsubsection{Contalngent Box}

The box in which the reintorced eurth structure was constructed was made of $12.7 \mathrm{~mm}$ thick sheets oi plpxigluss

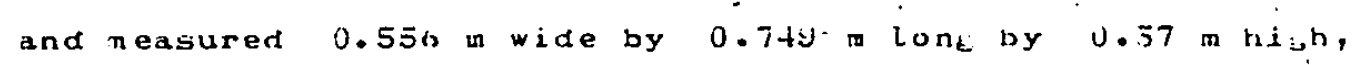
Fis.3.1. The actuul reinforced earth retainins, wall system 
itsel d measured $0.706 \mathrm{~m}$ long by 0.53 th hidh by $1.550 \mathrm{~m}$ wille.. These dimensions provide sufticient height to study the. streas conditions at several horizontal levels, and sufficlent width to minimize-the effect of side wall friction at the centre of the box where all measurements are taken." Plexiglass lends a smooth surface and thus minimizes tiriction with the sand ulong the sides of tive box.. A stepl erame was placed around the box in order toprevent excessive arching of the side walls.:

The box sat upon a metal base frame, to which was rigidly bolted an electrically driven vibrator.

\subsubsection{The sand}

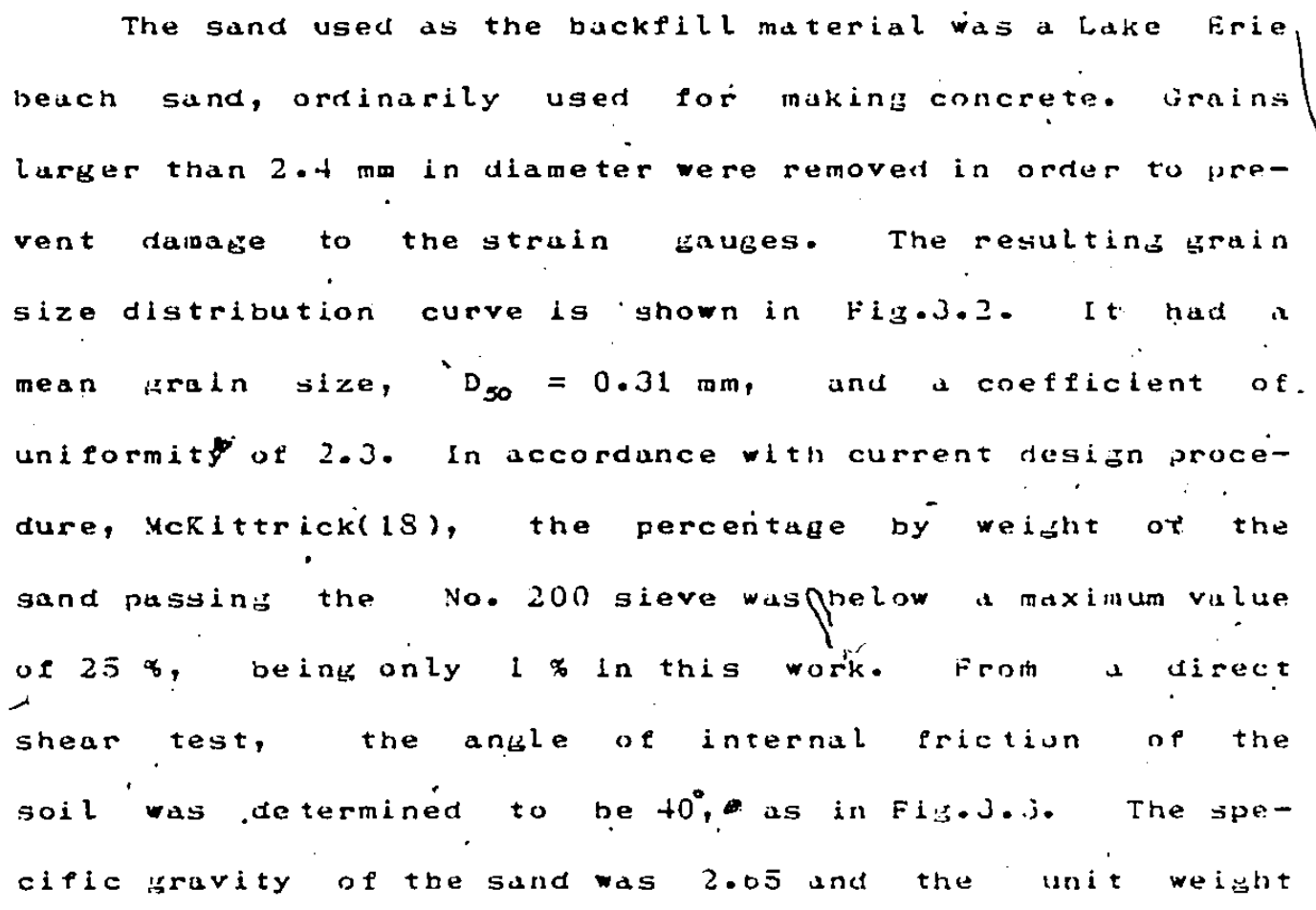




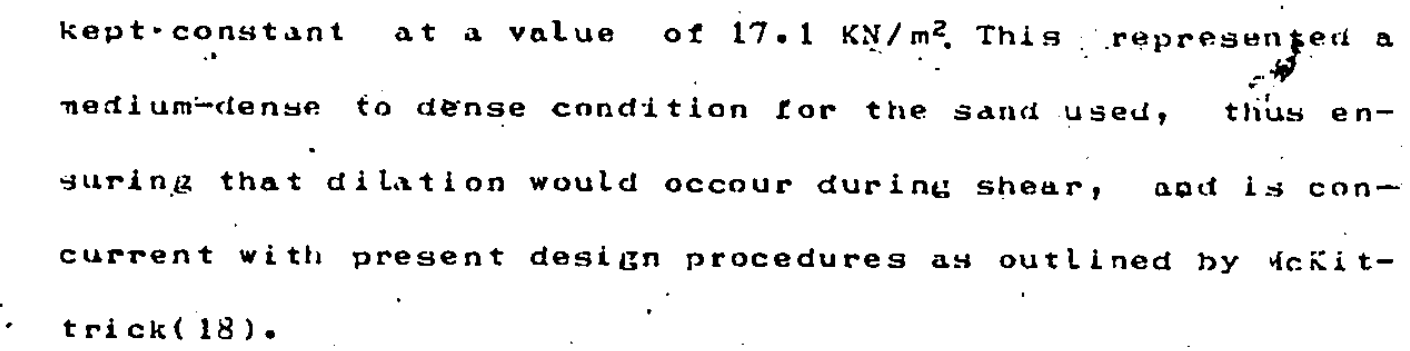

\subsubsection{The Relafercing strins}

The reinforcing strips.used were made of shim steel manufactured by Paxam Metaly Lta.. They meusured $0.025 \mathrm{~mm}$ thick by $25 \mathrm{~mm}$ wide by $66,5 \mathrm{~mm}$ Lung. The strij lenjths were selected to be sreater than 0.8 times the hieght of the wall, the minimum ratio allowed in design. Other dimensions chosen were based on work done by Mossaad(21) on a similar model contiguration. Preliminary load tests on the reinforced earth wall indicated fullure of the system by soilstrip glip at relatively low loads, so it was decifed to Litue sand to the top and bottom surfaces of the strips in urder to increase the.soil-gtrip triction. Tris permitted is higher loading of the system, enabling a greater range of medsurements to be taken.

The strips were blued to small plates of salvanized jteel which were attached to the skin elements with $3.2 \mathrm{~mm}$. diameter bolts.

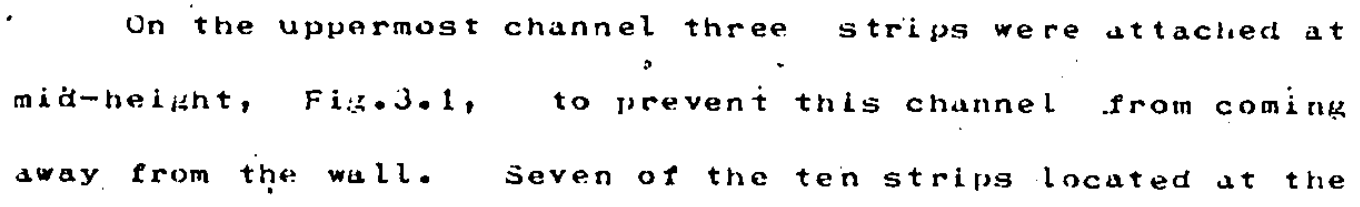




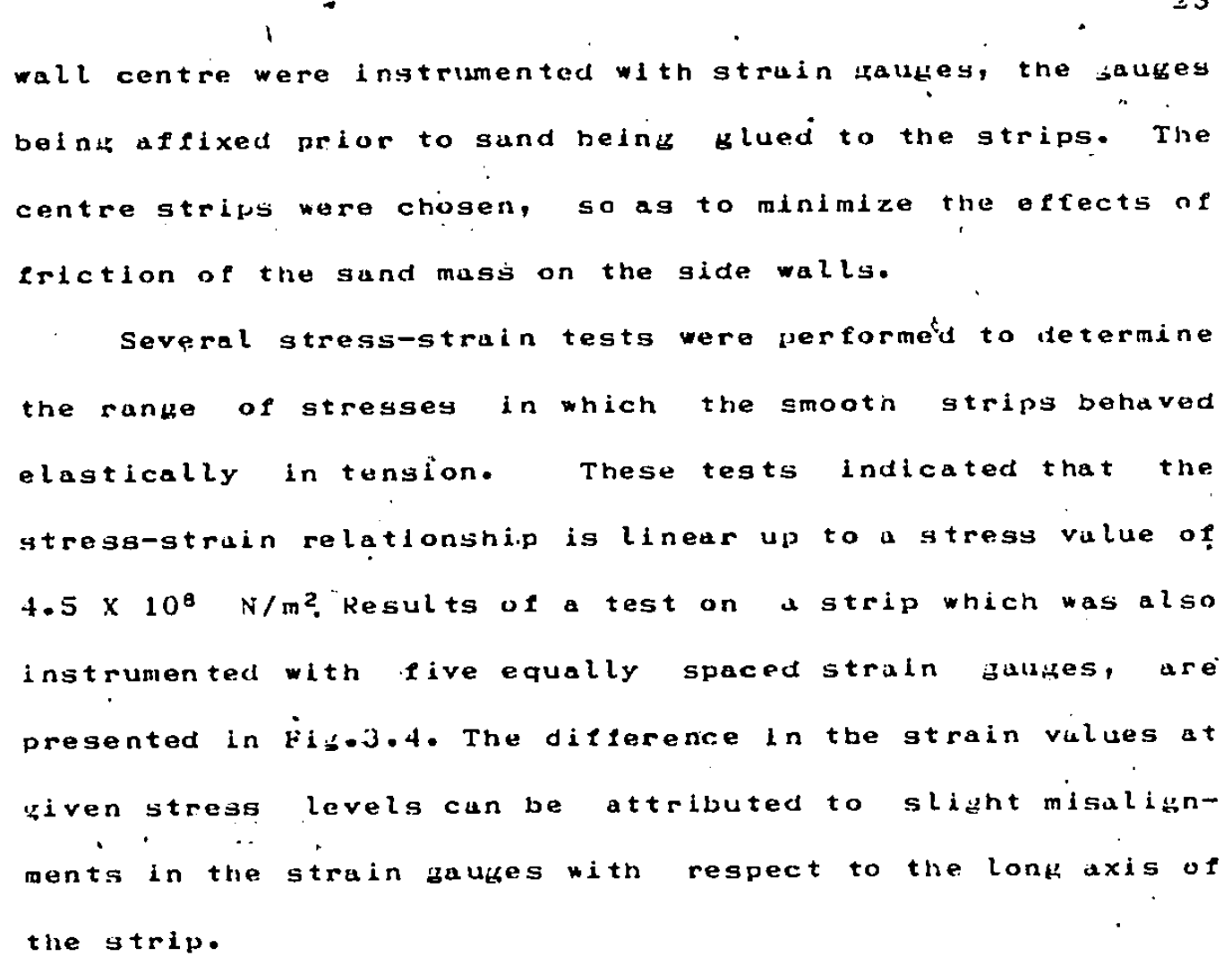

\section{2 .4 The Skln Elements}

The skin elements were made of galvanized steel channels, $50 \mathrm{~mm}$ hikh by $12.5 \mathrm{~mm}$ thange width and $0.5 \mathrm{~mm}$ thick, Flys.3.5 and 3.6. They spanned the width of the wox with a small clearunce at either side to avoid friction with the slde walls. Pieces of foam rubber were rilued on the buck of the channels at either end in order to prevent sand spilling out from the clearance. 


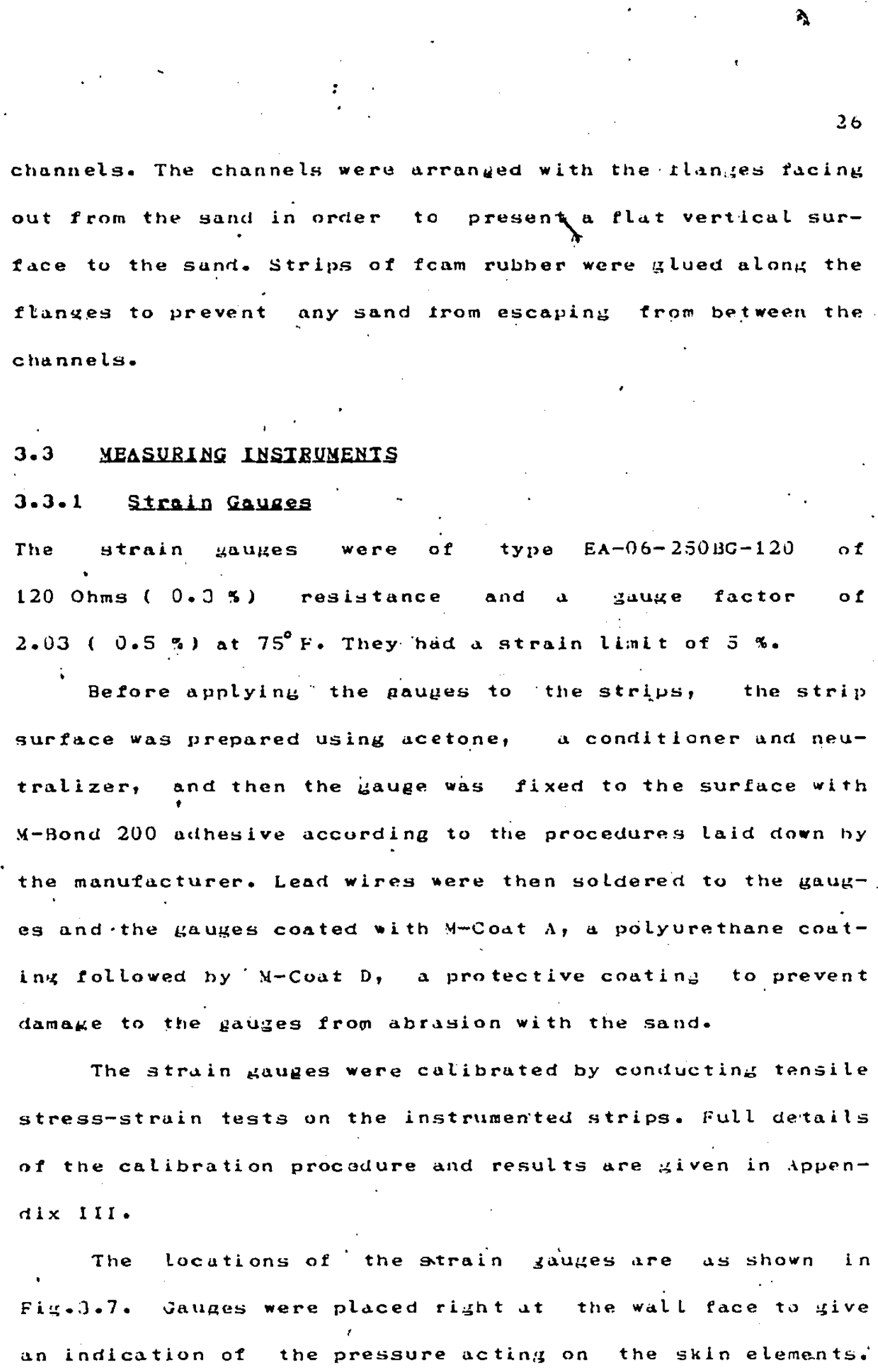

3.3 YEASURING INSTRUMENTS

\subsubsection{Strain Gauges}

The strain douges were of type EA-06-250BC-120 of 120 onms ( $0.3 \%)$ resistance and a guuge factor of $2.03(0.5 \%)$ at $75^{\circ} \mathrm{F}$. They had a strain linit of $5 x$. Before applying the gauges to the strips, the strip surface was prepared using acetone, a conditloner and neutralizer, and then the bauge was fixed to the surface with M-Bond 200 achesive accurding to the procedures laid down hy the manufacturer. Lead wires were then soldered to the gauges and the gauges coated with $y$-Codt $A$, a polyurethane cout-

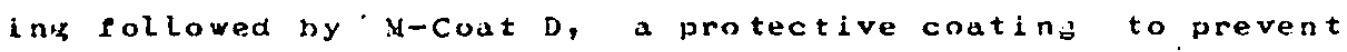
damake to the gauges from abrasion with the sande

The gtrain sauges were calibrated by concucting tensile stress-strain tests on the instrumented strips. Full details of the calibration procodure and results are isiven in tppendiX III. 
They were also placed along a line joining the base of the wall to the inside of the load block for loall locatiun II, as this line was assumed to be the boundary of the active and resistant zones for the load at location II. Thereafter, the aduges were evenly listributed alonis the strip length. No \&auges were placed at levels 7 and 9 , as these were nọt considered critical under conditions being investigated; neither were there bauses at the free enus of the gtrips, where strip tensile stresses are zero.

The gaukes were connected to a Vishay ELlis V/: $20-A$ electronic strain $q$ auke indlcator and $V / E 22$ automatic printer, by eight V/E 21 switch, balance and calibration unit.s capable of reuding up to 80 gauges simultaneously, Fij.3.o. In this work, only 39 straln dauges were used, as using too many might have interfered with the hehaviour of the system.

\subsubsection{Dial Gayres}

Ten diul zauges, reading to an accuracy of 0.001 ot in inch, $(0.0254 \mathrm{~mm})$, were placed at the wall front to record the wall moverent, fijo3.3. liach dial bauge was located it the centre of each channel along the centre line of the wall. 


\subsection{CONSTRUCIICN PROCEDDRE}

The reinfurced earth retisining wall nodel was built up in a series of layers. The same seneral procedure was followed in all tests.

The lowermost channel was placed on the floor of the box, with its flanges tacing outwards, und hald in place by two wooden posts. A predetermined weight of sand, ( to ensure a unit weight of $17.1 \mathrm{KN} / \mathrm{m}^{2}$ was poured in behind the channel. The electrical vibrator was switched on und the sand surpace tade borizontal by frowelling it plugh with the top of the channel. Three strips were then placed alonis the sand surface at 203 min horizcntal intervals, with une. end lyinfs over the flange of the chaniel. The next chunnet was placed on top. Fls.3.10, and the two channels and strips boltod tojether. In placing the instrumented strips the wires were laid uloniz the sand at the side of the strins so us not to interfere with the soil-strip interaction. More sund was placed on top of this tirst layer and the procedure repeated until the reinforced earth wall had been fully constructer. Then the wooden posts were takgh away from the pront of the wall und the dial gaues and strain sauges were all set to zero, and the model was ready for louding. Upun romoval of the suppourting wooden posts the system reinained stable and after all puleses had been zeroed there was to detectable creep. 


\subsection{LQADING NECHANISM}

- The arrangement used to apply the load on the sisrace ot the reinforced earth retaining wall backfill is shown in Firs. 3.11 to 3.1.3. It consisted of a metal block, $106 \mathrm{~mm}$, in cross-jection which was flaced on the sand surface, purallel to the wall, face, and spanning almost the whole width of the box. A leverage system, Fib.3.11, was then used to apply the load on the bluck, in which dead weights were suspended from the end of u metal beam by a hanker. A metal erame bolted to the ploor provided the rodction required to keep the system in equilibrium. The load was applied cen-" trally on the block through a $25.4 \mathrm{~mm}$ dialneter steol rod with its.longltudinal axis lying, directly above the central uxis of. the block, Fig.3.14..

In order that the horixcntal force on the block be fully trangaitted to. the suil mass it was required that friction with the vertical load component be minimized. This was achieved by attaching to the top of the biock two slates capable of moving relative to each other on frictionless runners, Fip.J.14. Course abradinu puper was alued to the base of the loaking block to further effect the loud transmission to the soil. 


\subsubsection{Leading Procedure}

\subsubsection{Vertical Load}

To apply, the vertical load the loading apparatus was set up as described, the louding block placed, on the soil surface and the beam jositioned to take the welgits. Calculations had been prepared prinr to loading to determine tibe vertical lour on the soil surtace. due to the weiahts placed on the hanaer at the end of the beam. The maximun vertical loud applied to the model correspunded to a stross of $100 \mathrm{KN} / \mathrm{m}^{2}$ under the footlng. This compares gavourably with actual live loads in the region of $30 \mathrm{kN} / \mathrm{m}^{2}$ as measured by Juran et. al-( 15$)$, on a brldce abutment, and tests performed by Al-bussaini and perry(a) who loaded their wall up to $90 \mathrm{KN} / \mathrm{m}^{2}$

\section{5 .1 .2 Horizontal Load}

These loads were applied in two directions:

1. Towards the wall face.

2. Away trom the wall face.

In the former case, the model was positioned so that the wall faced towards the end of the base frame to which the pulley was affixed, Fím.3.12, and in the latter, the model was simply turned around the other way, Fis.3.13. Preliminary testing indicated that the muximum rationf horizontal to vertical load was in the region of 0.42 . Above this valie local shear failure of the soil-reinforcement 
system in the inmediate vicinity of the strip load occoured rue to an excessive inclinuticn of the resultant. In order to prevent this lrow upsetting the experimental programme it$$
\text { was decided to keep the maximum value of this ratio to ap- }
$$

\subsection{TESTXNG PROGRANME}

The proigumme was formulated to investighte the erfects of vertical and horizontal loads on a reinforced earth retuining wall with direct reference to the sistem as a bridie abutment. From preliminary tests, stresses in the strips due to the weikht of the soil alone were tiound to be quité siall, so in taking the measurements, the weint of the soil as a contributing ractor to developement af the stresses in the strips was not considered, as this effect has heen studlex elsewhere, $(3),(21),(25)$. To this end, all medsuring devices were zeroed atter wall construc:tion. 
Four load locations were considered, Fij.3.15:

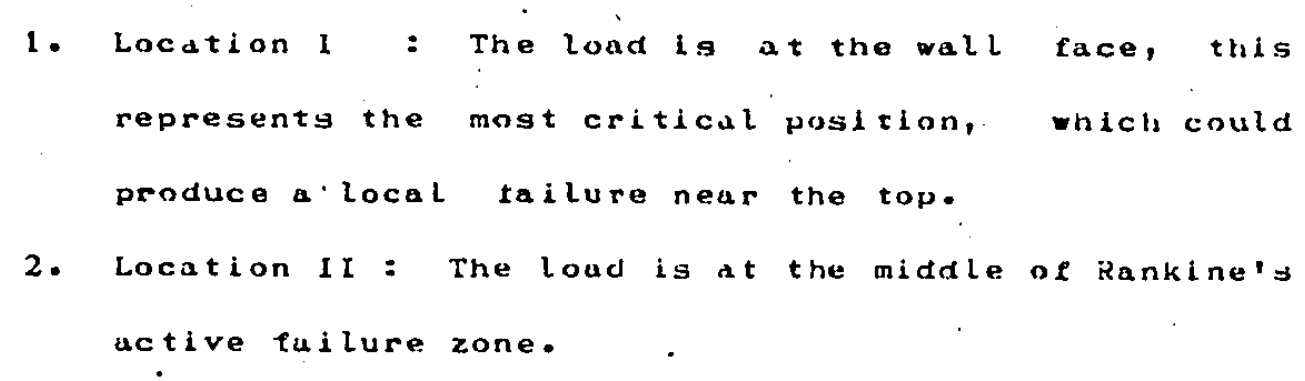

2. Location II : The load is at the middle of Rankine's active fuilure zone.

3. Location III:- The load is just inside the Runkine failure zone.

4. Location IV : The load is just outside Rankine's paiLure zone.

The Rankino wedge was chusen as an arbitrary reference polnt for the load location, and as such the $45+\phi / 2$ line is not intended to represent the boundary between the active and resistant zones.

At each location a vertical load wasflest applied, ranglng from $60 \mathrm{kN} / \mathrm{m}^{2}$ to $100 \mathrm{KN} / \mathrm{m}^{2}$. In some cases, the strain and wall deflection readings were taken at lada increments up to the fully applied vertical load.

Once the vertical load was applied and all readings taken, the horizontal load was applied. In,all cases, the norizontal load was applied in sevoral increments, and readings taken at each luad increment, in order to bive a picture of the developement of stresses in the strips dup to the application of the horizantal loud. Table 3.1 summarizes the experimental propramme. 
A preliminary test was conducted in order to determine the vertical surcharfie load at which the wall would fall, bo that thig situation would not occour during the experimentul prokramme. The load was positioned at load lucation II, and a vertical surcharte only was applied. The reinforced earth system failed at a surcharge load of $314 \mathrm{KN} / \mathrm{In}^{2}$. This ensured that the system would not fall during the subsequent testing prouramme, wherein tho maximum vertical surcharge load was $100 \mathrm{KN} / \mathrm{m}^{2}$. 


\section{Chapter IV \\ PLESENTATION AND DISCUSSION OF EXPERIMENTAL RESULTS}

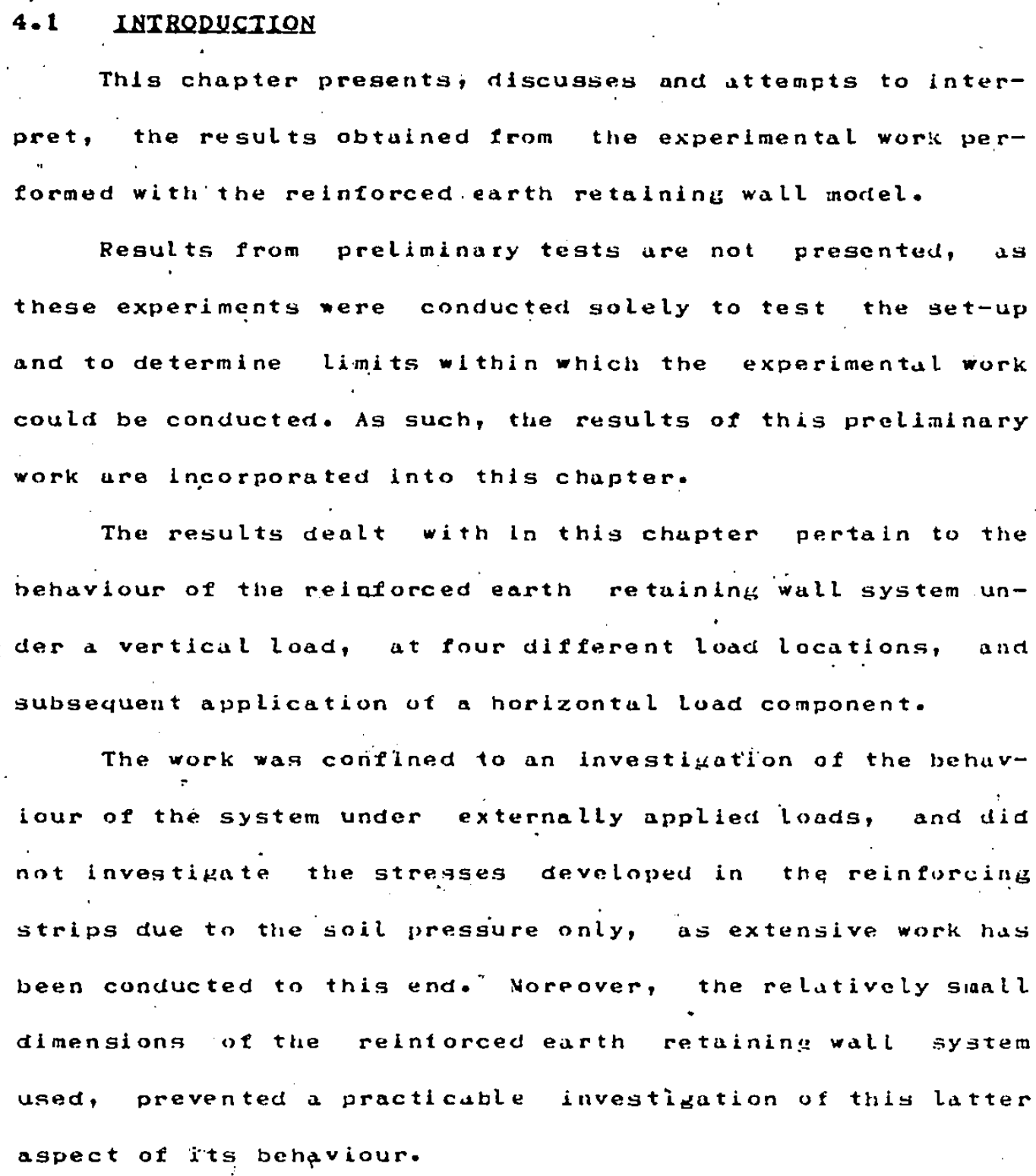




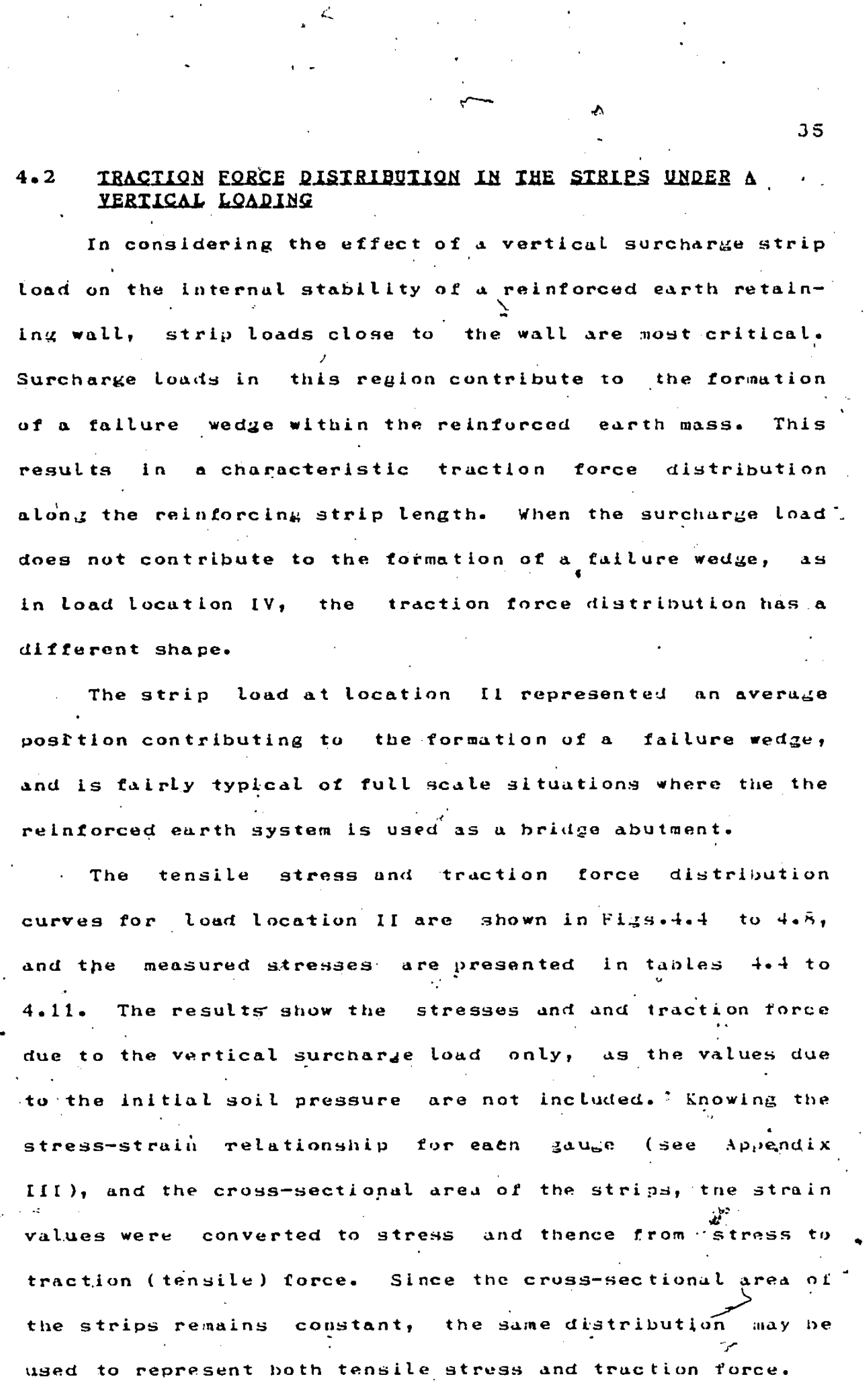

4.2 TRACTLON EOREE DISTRIRUIION IN THE STRIPS UNRER A. YERTICAL LOADING

In considering the effect of a vertical surcharge strip load on the internal stabllity of a reinporced earth retalnIn'wall, strij loads cloge to the wall are nostcritical. Surcharge lousts in this region contribute to the forination of a fallure wedze within the reinfurced earth mass. This regulta in a characterlstic traction force distribution along the reinforcing strip length. When the surcharbe load: does not contribute to the formation of a fallure wedige, as In load location IV, the traction force distribution has a diferent shape.

The strip load at location I represented an averuge position contributing to the formation of a fallure wedge, and is falily typical of full scale situations where tie the reinforcod eurth system is uspdi as u brillge abutment.

The tensile stress and traction force distribution curves for loar location I are shown in Fiss.t.t to $4 . \bar{x}$, and the measured stresses are presented in tailes 4.4 to 4.11. The results show the stresses and and traction force due to the vartical surcharde load only, as the values due to the initial soil pressure are not inclucted. "Knowing the

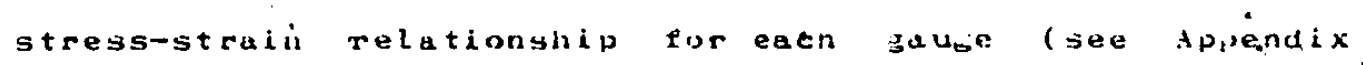
II , and the cross-sectional ares of the strija, tre strain values wert converted to stress and thence from stress tis, traction (tensile) force. Since the cruss-sectionil area ni. the strips remains constant, the sine distribution illay be wyed to represent both tensile gtress and truction force. 
Considering the fraction force distribution curves, (Fiks.4.2 to 4.12), tho ordinates, which represnt the tractlon force at any point along the strip, follow the saine putern for each strip at each level, namely: erom a non-zeró value at the wall face the traction force,increases to a maximum, at somedistance alond the gtriptrom the wall face. Tris distance, as can be sejen from the rigures, varies wlth depth. From this maximum. value the traction force the refuces along the length of the strip to zero at the free end. Upon closer inspection, this listrubltion has certain copinite characteristics which are evident in every strip. These are:

1. The traction force measured at the wall faco is noto a maximum, and is non-zero.

2. Movina away from the wall, the traction force increases to a muximum value at gome distince alont the strip from the wali lace. The location of the point of maximum traction force will vary with the denth of the sirip and the load feation."

3. Beyond the point of maximum traction force, decreases linearly (at the same rate as. It increases from the wall face) over, a certainfportion of the strip lenth, and thereater.

4. Tre rate of decreuse is reduced as the rorce decreuses to zero at the free end ni the strip. 
This type of force distribution curve has been observed in previous work (3), (21). Kennedy et. al. (16) have proposed an ldealized distribution for it.

The distribution ls jugtifled as collows: The verticul strip lood applied on the surface of the sand will result in distribution of vertical gtsesses within the mass as proposed by Boussinesq. shoussinesq's distribution can be approximated by assuming that the vertical gtress is contalned within the 2: 1 dispersion lines, wherein it varies only with tepth, and outside this reuion the vertical stress may be a considered neglieible, Fld.4.1. From a consideration óp .statlc equilibrium of the vertical gtress in tre soll, $\sigma_{v}$, and the traction force $x$, in the reinforcins girip, the followiog relationship is obtained:

$a T / d l=2 \cdot b \cdot\left\{\cdot \sigma_{r}\right.$

$\therefore 4.1$

where dr/dl is the slope of the traction force distribution alonis the strip, and b und are ds deflued in section $2.2 \cdot$, Heace the slupe of the traction force is in direct proportion to the vertical soll stress. Since the vertical soil strejs is assumed to be constant within the $2: 1$ dispersion lines, the slope of the traction, force distribution curve should have a constant value in'this renion. However, ds can be sten from all the fikures, it is the masnitude ot this, slupe which remained unchanged, as the slope changed from a positive to negative value within the region of the $2: 1$ isis- 
persion lines. The reasun for this is that upon application of. the load, a failure wedge was formed (somewhat akin to the Runkine active wedye), which tenced to move laterally; towards the wal. Consequently, witinin this wedse the frictional etresses exerted by the soil on the strips were directed towarcis the wall,. Whereas in the resistant zone they were directed away from the wall. Thus, the value of the slope changed from positive to negative across the boundary from the active to the resistant zone, whilst the magniture of the slope remained approximately the same ialue throwghout. This is particularly noticeable at level 4 in Figs.4.4 and 4.6 to 4.8. The traction force, being the summation of of the frictional stresses of the soil on the strip, incroased from its value ut the wall face to a maximum, due to the upplication of these Mrictional stresses in a direction towards the wall face, Flg.2.5. Once the frictional stresses were directed in the opposite direction the traction force reduced from its maximum value, until it became zero at the free end of the strip.

Outside the 2:1 dispersion lines the vertical stress in the soil due to the surcharge lodd was greatly reduced; thence trom. equation 4.1 , dT/al will be much smaller, ard this can be verified from tre distributions in Figs.tet to +.S. This effect was especiully noticeable in Fi..4.5 und also in the uppermost strip ln each of the tegits, but less so la the lower gtrips. This may be explained by considering 
the Houssinesq distribution of vertical stresseis in the soil, Fig.4.1. From the diagram one can see that at ghallow depths relative to the width of the loud, the vertical stress quickly reduces to zero outside the 2:1 dispersion -lines, but ät kreater depths.the reduction to zero is less pronouncer. .

The masnitude of the traction forces at all polnts along the strips, as can be seen for example by comparing Figs.4.4 and 4.7, was proportional to the magnitude of the surcharge strip load.

- For different surcharue loads, but at the sure load locution, the overall shape of the traction force distribution remained similar for each strib, whilst the mannitude of the traction force increased. It is worthwhile to note that the sreatest proportionate increase in the inauniude of the traction torces occoured within the $2: 1$ dispersion lines.

\subsubsection{Lead Apolled at Varleus Lecotions}

As previously mentioned, the position or the loud il aftect the shape of the traction force distribution curve. For the load at locations I, Il and II the distribution is essentially the same, with little overall afferences, huwever there is a departure from this type of distrinution ror : the load at location IV. 


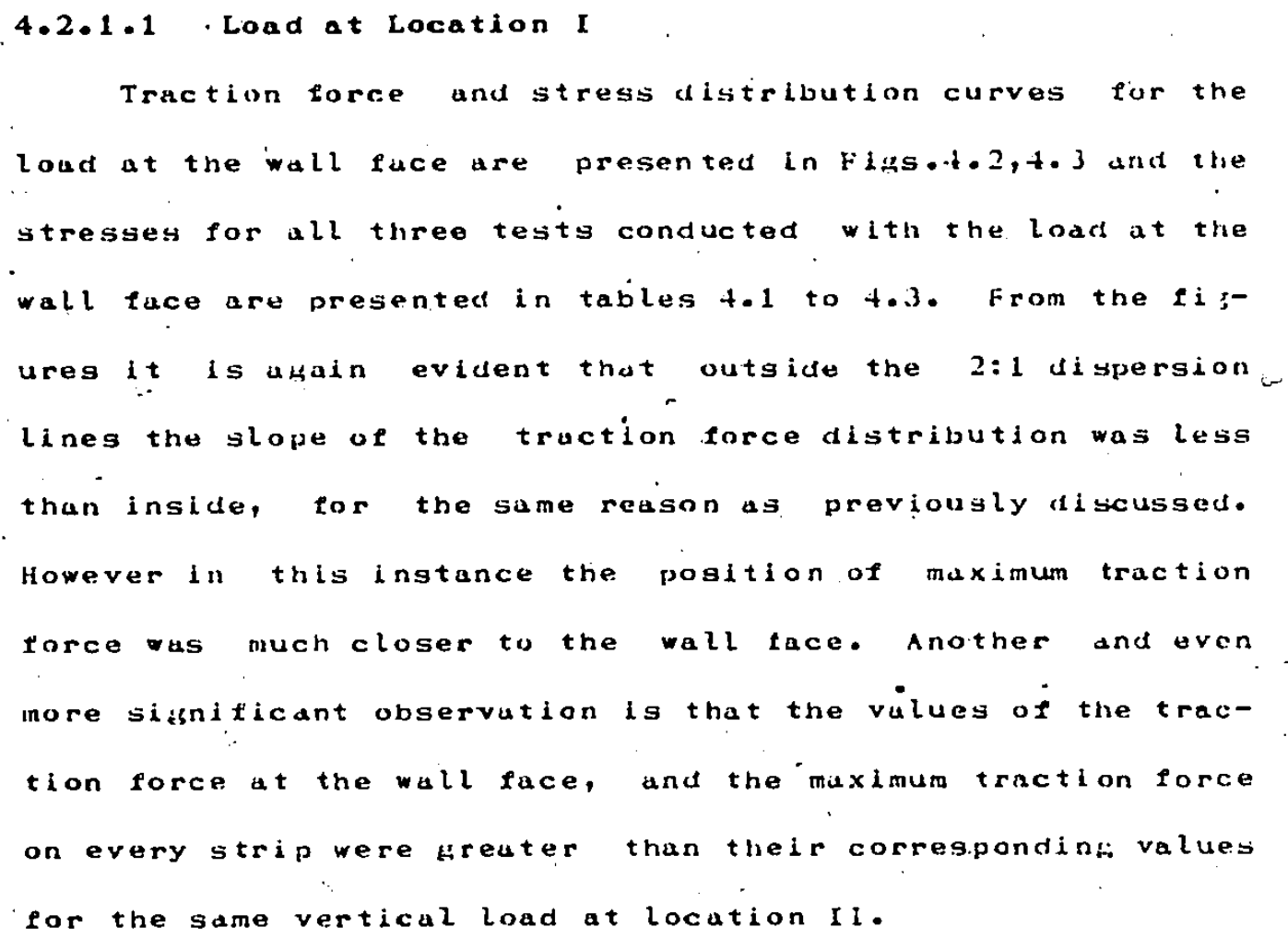




\subsubsection{Load at Location III}

Traction torce and stress distribution curves for this case are shown in Figs.4.9 and 4.10 , und the strij stresses are presented in tables 4.12 to 4.15 . Notice that here the maximum stresses in the strips were located further away from the wall than in the previous two instances where the

loads were closer to the wall. In addition, the traction forces at the wall tace and the value of the maximum traction force were less than their corresponding values for the same surcharee loads at location II, as tray be observed by comparinar Figs.4.9: to 4.4 and 4.10 to 4.7.

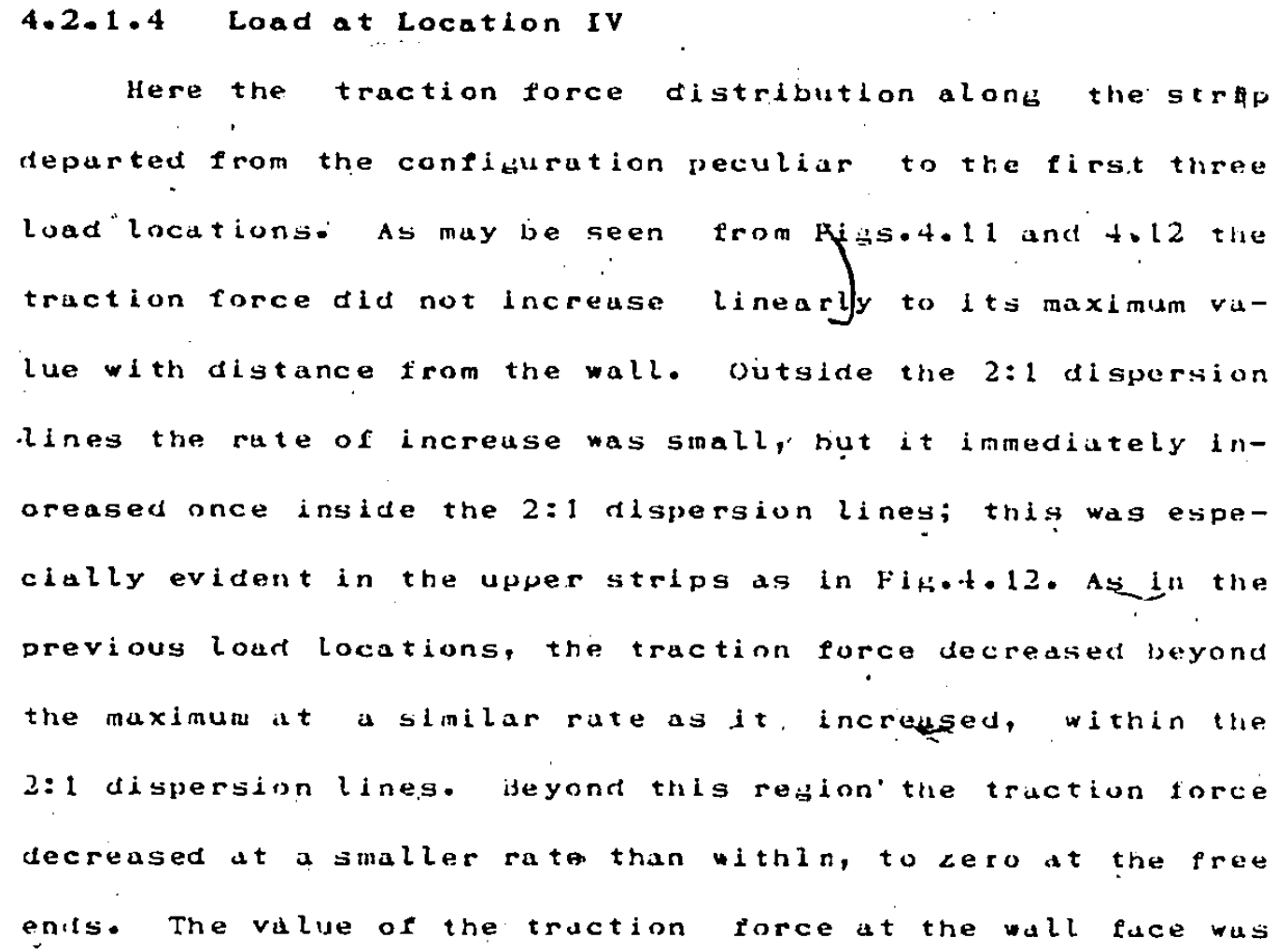


virtualiy zero for the load in this location hence the existence of the wall was of little or no consequence in influencing the traction force in the strip due to the surcharge load applied in thig position. In erfect, this situation may be considered approximate to that in which a loadis applied on a semi-infinite reinforcer soil mass. The values of maximum traction force on each strip for the load in this location were ugain lower than those for the sume vertical loud at location III, as may be observeá by comparing Fiks.4.11 to 4.9 and 4.12 to 4.10

\subsection{LQGATION OE THE EAILURE RLANE}

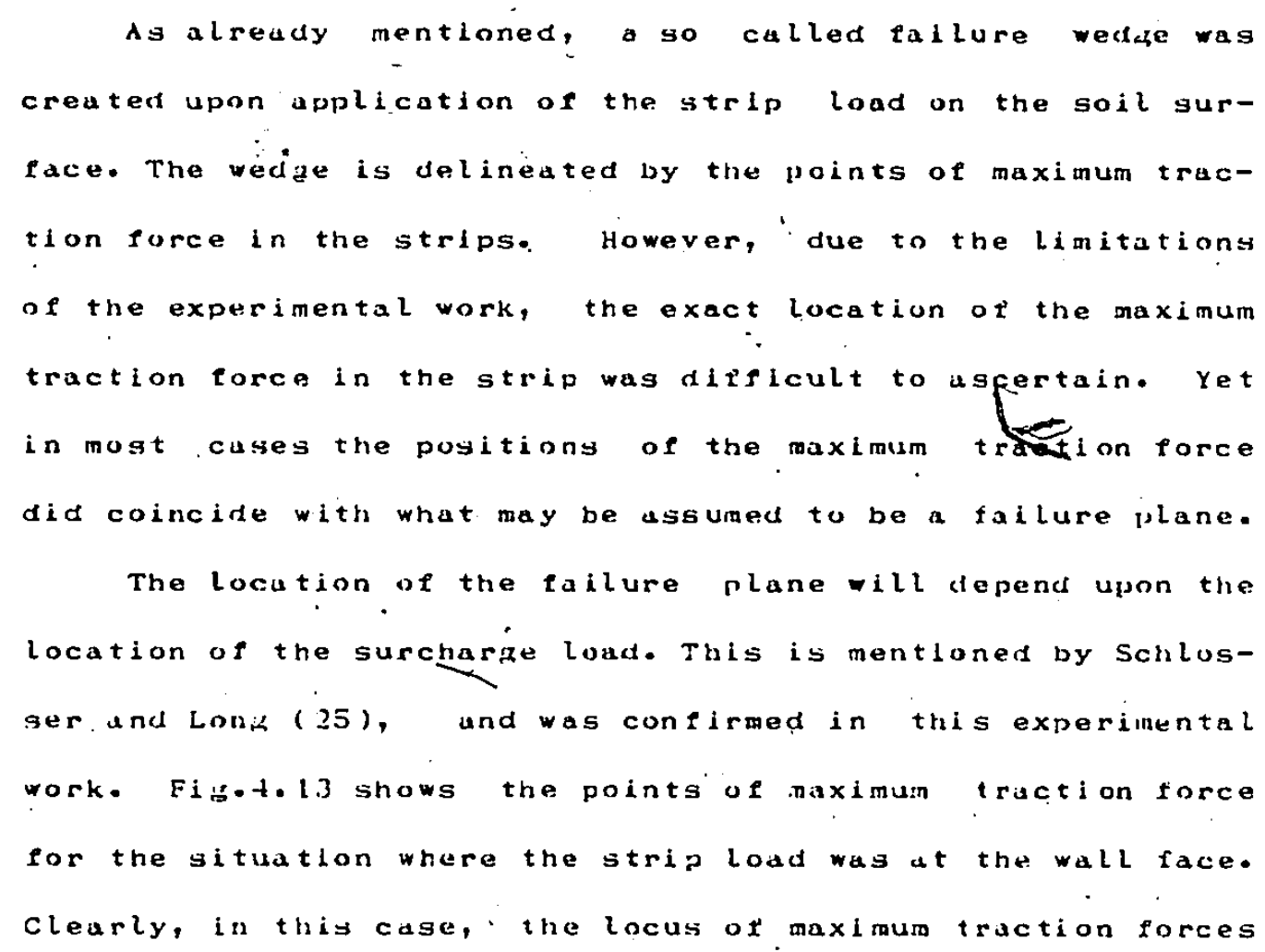


may be approximatad by a straight line jointng the base of the wall to the inside edge of the strip loid. Inis approximation may also be used to define the failure wedize formed by the strip load at location II, Flib4.14, the points of maximum traction force again being on the gtraight line Joinling the base of the wall to the inside of the strip load. In this case, the kauges lay along the assumed failure plane, which caused the maxima to coincide exactlywith the stralght line, whereas for load location I, the caures were slightly offset from this line, but it ls noted in the former case that it was the auges nearest the straight line which registerect maximum values.

For load location, held for all the ingtrumented strips, save the top and bottom strip, Fix.4.15, and for load location IV the straight Line approxination turther departed frcm the locus of maximum traction torces, Fis.4.16...

In each case the straight line approximation for the failureplane is that determined from Culmann's graphical solution for the earth pressure behind a retaining wall due to a surcharge load. For locations $I$, I and IJ it is cleur that Culmann's solution is a valid method of determinins the possible failure wedge in the case of a reinforcedearth wall subject to a strip surcharge. load.

Further awis from the wall, the locus of muxinum triction forces did not coincide with the culmann line fur the 
load at location IV. The existence ot the wall was or less significance in this case as this load location appruached that of a load on a semi-infinite reintorced earth mass. In this instance it was observed that the bauges registering maximum values were closest to a straight vertical line be-. 4.

low the central axis of the strip load, Fig.4.16. This gtralght line is the locus of maximum vertical stresses in u gemi-infinite mass due to a surcharge strip load, which would be a more realistic interpretition of the locus of maxlmum truction forces observed for load location IV.

\subsection{YAXINUM IRAGIIQN EORCE $\triangle S$ A EUNGTION OE DERTH}

In considering the falure or a reinforcied earth retaining wall syster by breakage ot the atrips, the effect of the load, itg magnitude and location, on the value of the maximum truction force in the strips at different depths must be known. Thls experlmental work has facilitated in describing the variation of maximum traction force with depth. The beneral shape of this curve was consigtent for all load locutions, the tendency boing as follows: the maximum traction force Increased to a maximum value at-- some depth below the surface, and thereafter decreased, fown to level, .10

\footnotetext{
Resists for the distribution of maximuin truction force *ith depth for load location I are presented in Fin.t.17. The maximum value in this case occoured at level 3 . If these
} 
firures ure compured to those for load location II,

Fiz.t.18, two points are quite clear:

1. At all levels the maximum traction forces for load location I were sreater than those ior loud location II, for the sume surcharge lodds.

2. The level at which the maximum stress occoured had moved down to level 4 for load localon II, for all three surcharke load magnitudeg. Distribution tor load location II aro given, in Fik.4.19. It ls observed atain that the values ot maximum. truction force for thls load location, at all levels, were less than those for load location 1 l, for the same surcharige louds.

Distributions for load location. IV are, given in Fir.4.20. Aguin the values of maximum traction force wera: less than those at corresponding levels for the same vertical surcharge load at location III.

From the dhove results it is clearly evident that the proximity of the strip load to the wall face plays a larje role ln determining the magnitude of the traction force in the strips. The closer the load is to the well face, the ureater the value of maximum traction force in the strilis, tor a given masnitude of surcharge load. Thus with rospect to tensile fillure of trie reinforcement due to a strip load scting on the surtace or the reinforced parth muss, load location I is the most critical fas evidenced by the nifhest 
truction force recorded, sec level 3, Fig.t.17). As the Burcharge load muves away from the wall, the effect of the wall upon the traction force in the strip is reduced, until a point is reached beyond whlch. no further reduction in the traction force ig posstble. This point is the same roint at which the. load may be considered to act upon a semi-intinite relnforced carth rass.

\subsection{BEHAYIOQY OF THE YALK EACE}

The movement of the wall was monitered in all tests as it.was felt that its derlection ought to reflect measurements of the traction force, and would shed lizht upon the deformation mechanism of the reinforced earth retaining wall under a strip loadina. Regults of the wall deturmation are. pregenter in Figs.4.21 to 4.28. Wall deplection readinis are presented in tables 4.20 to 4.37 . The deflected shape of the wall did inceed reflect the shape of the distrinution of the maxinum strip traction force with depth in the fol. lowints 'ways:

1. It increased to a maximum at some depth below the sand surface lexcept for load location I where the outward deflection is a maximiam in the uppermost channel), and thereafter rerluced to a lower value at the bottom.

2. The outward deformation of the wall reduced at all levels is the surcharye strip load moved further away., from the wall. 


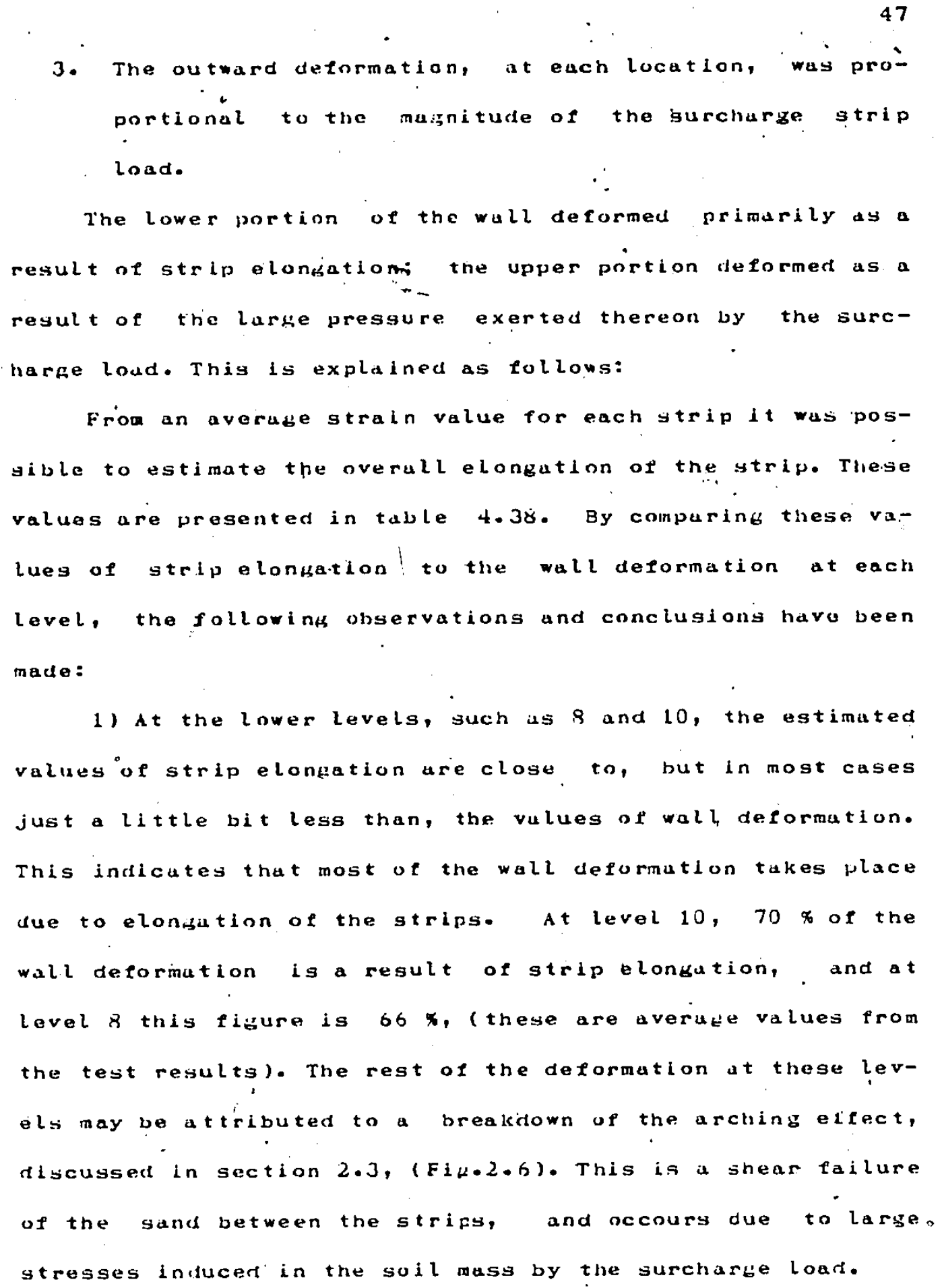

3. The outward determation, at each location, was pró portional to the mainitude of the surcharge strip . load.

The lower portion of the wall deformed primarily as a result of strip elongatiomi the upper prition deformed as a result of the large pressure exerted thereon by the surcharge loud. This is explained as follows:

Frion an averuge strain value for each strip it was posgible to estimato the overull elongation of the strip. Tliese values are presented in table 4.38̈. By conparing these values of strip elongation to the wall deformation at each level, the followins observations and conclusions havo been macle:

1) At the lower levels, such is 8 and 10 , the estimated values of strip elongation are close, to, but in most cases just a little bit less than, the vulues of wall, deformation. This indicates that most of the wall deformution takes place wue to elonistion of the strips. At level $10,70 \%$ of the wall deformation is a result of strip elongution, and at level 8 this figure is 66 \%, (these are averuge values from the test results). The rest of the deformation at these levels may be attributed to a breakiown of the arching effect, discussed In section $2.3,(E i k \cdot 2.6)$. This is a shear failure of the sand between the strifs, and occours due to larye. stresses inducer in the soil wass by the surcharge loar. 
2) At tho upper levels, strip elongation is'a much smaller contributing factor to the wall ceformation, as may be seen frow the large difference between the values in tuwle 4.38, and those presented In Figs.4.21 to 4.28 . For instance, at level 4, on averaye, only 42 , of the wall deformation is due to the strip elongation, and at level 3 this figure is $36 x$, (asain these are average values rrom the l test results). The rest of the movement in the upper portion of the wall is due to the breakdown of the arching effect. Thls effect is much ureater in the upper portion of the wall, as in this rebion the stresses, induced in the soil by the surcharge load are much higher, resulting in a more extensive breakdown. In addition, further confirmation of the dominant effect on the wall deflection played by the lareer soil stresses in the upper levels, is that tne deplection in this region for a given maknitude of the surcharge strip load ls greatest when the surchurue load is it" the wál face; and diminishes as the load inoves further awuy from the wull.

\subsection{EEFECT OF HOBIZONTAL CCNPONENT ON TRACTION EORCE DISTRIBUIION}

The horizontal loud was applied in two directions, to- . wards and away from the wall. These two cases yieldod significantly different results and will be treated seperately. 


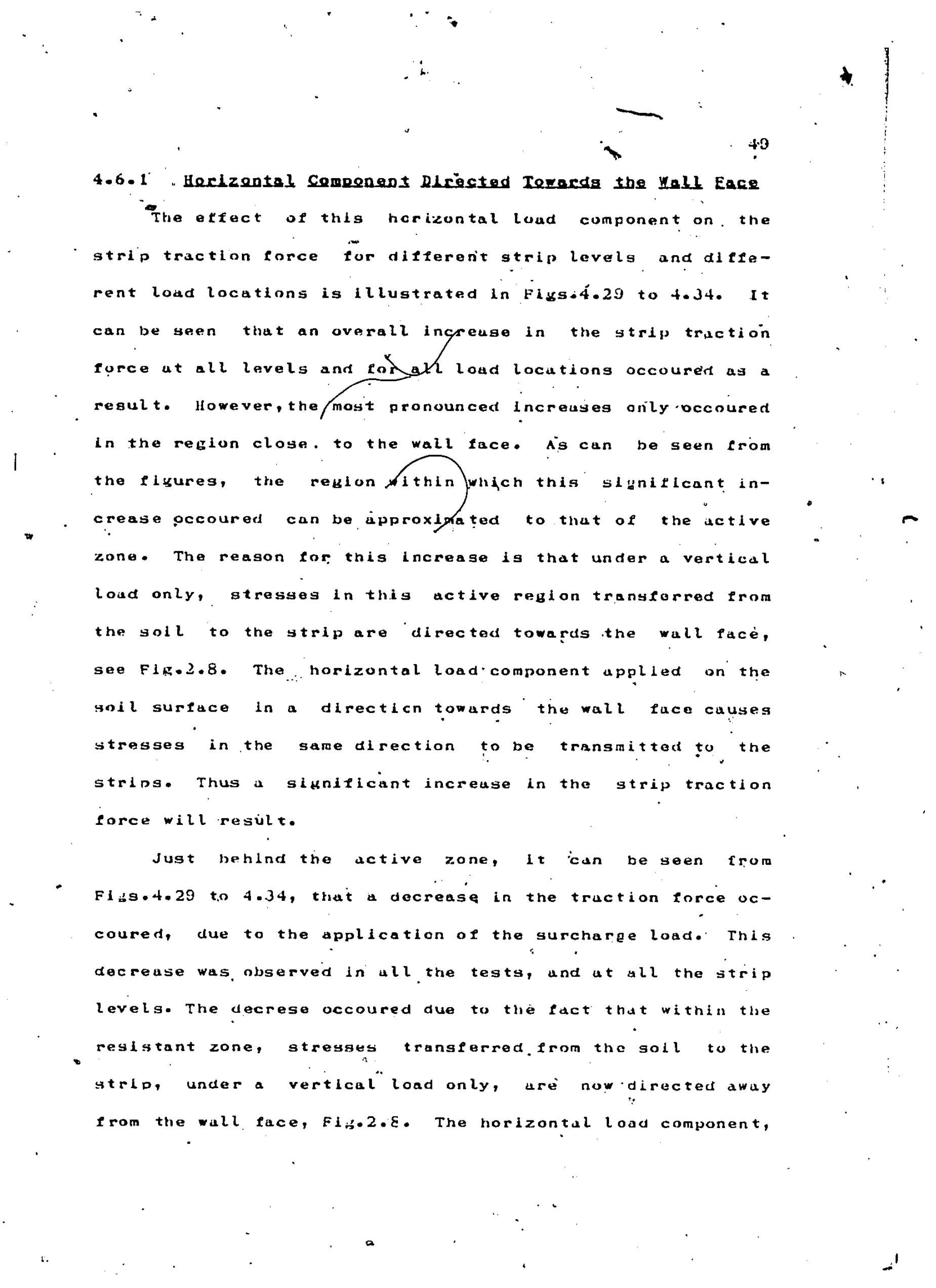




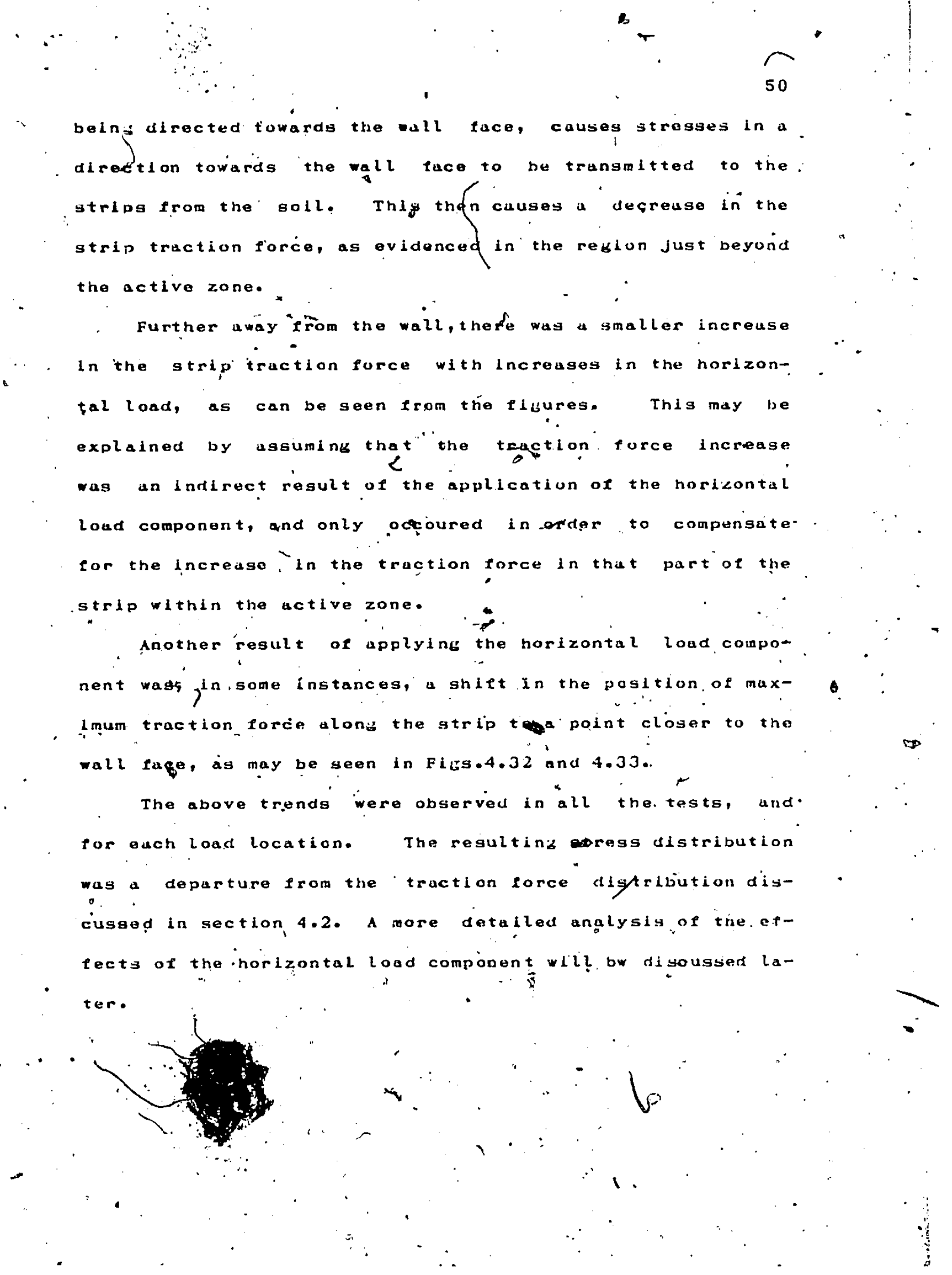




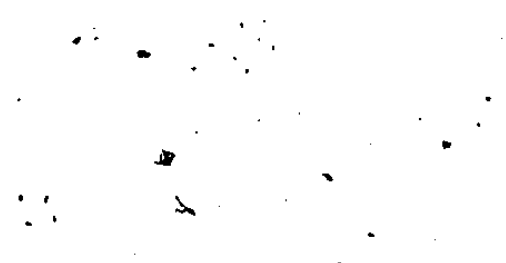

4.6.2 Hecizental cempenent Rirected Amay Erem the Wall Encas

Directinu the horizontul load component uway from the

wall faceprasultg in changeg in the gtriptraction force as shown in 1 igs.4.35 to 4.40. It can be seen that withln the active wedge the traction force reduces in all cases upon application of the horizontal load. In order to explain this, one must refer back to Fig.2.8, which shows the stresses transferred to the gtrips from the soll, under a vertical surcharge load, to be directed towards the wall Sace within the active zone. The application of the horizontal load component away from the wall tace causes stresses in a like alrection to be transaitted to the stripswithin the active wedge. This then cuuses a reduction in the ytrip traction force in this reglon.

It is clear from Figs.4.35 to 4.40, und was apparent in varying degrees for each strip in all the tests with tro loud directed away from the wall fuce, that it is the maximum traction furce value which decreases leust of all with the application of the horizoritul load increments. Inis can be explained ay follows: Upon application of the vertical surchargo louk a potentlal failure plane was formed within the reinforcer ourth wass. The failure plane is defined by. the locus of maximus traction forces in the strips. Once the fuilure olane has been tormed and stresses have been mobio lized along it, (and these stresses result, in the maximum - traction forces in the strips), apulication of the horizon- 
tal loud component away from the wall was unable to nave a restorative effect, on the failure plane, and was therefore ineftective in reducing the stresses.which result in the maximum traction rorces. inls effect was further confirmution of the formation of a potential tailure plane. It may be observed from the above figures, that within the resistunt zone, beyond the potential fuilure plaue, there is a reciuction in-the strip traction force, upon application of the horizontal load componént. This may be explained by considering that within this region, under a vertical loak only, the stresses mobilized on the strip surtace are directed away from the wall tace, fif.2.8. The etfect of applying a horizontul loud component to the sand surface, directed away from the wall face, was to introduce " Lateral compressive stress to the reinforced earth system in the resistant zone. rhis compressive stress hus the effect of reducing the required soil-gtrip struss trinsfer whid this zone, hence the redution in traction force. In all tests it was observed that this effect became less noticeable with depth, and below level 5 a small increase in the traction force was observed in the strips in the resultunt zone. 
4.7 EEEECT OF HOBIZONTAL SOMPONENT ON LOCATLON OE THE EAILURE RLANE

Figs. 4.41 to 4.46 pregent a plature of the shift in the point of maximum traction force in the strips, from the situation under a vertical load only, to that with the full. horizontal loud comfonent applted. As can be seen from the firures, the application of the horizontal loud component resulted in a smallshift or the point of waximum traction force at some levels; in each case the shift was in the same direction as the horizontal load component. Hence a small shlet in the point of maximun traction force is. likely to occour in the direction of, and proportional to the horizontal load component. However, the shift in the maximism was not always possible to pinpoint, especially for gmaller values of the horizontal load component, as only a limited number of strain gauges were placed on each strip, for reasons mentioned in section $2.3 \cdot 1$.

4.8 EFEECT OF HQRIZONTAL SOMPONEENT ON MAXIMUM SIRLP TRACILON EQREES

The effect of the horizontal load comporient varies areatly between that directed towards, and that directed away from the wall face, and hence the two cáses will be treated sepurately. 


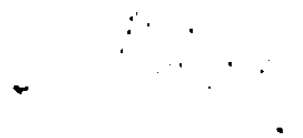

4.8.1 Hecizontal Component Dleacted Torords tbe Hall Eace Figs. +.47 to 4.49 shọ the effect of this load cumponent on the maximum traction torce values. I $t$ may be seen from the Pligres that an increase in the maximum traction force in every strip was noted with, each increase in the norizontal load component. The rate of incrouse, as is evident from the figures, diminished as the load moved further away from the wall.

\subsubsection{Herizentel compenent Dicected Aray Erov the Wall Eace}

As mentioned and explained in section 4.6 .2 , it was the values of the maximum traction force which decreasd least of all upon application of the horlzontal component away from the wall face. The reason being that these maxima lie upon the potential fallure plane. As a result, verylittledecrease was noted in the values. of the maxima at all loveli, as may bo seen in Figs.4.50 an'd 4.51.

Hence the values of maxiaum traction force may be cunsidered not to be influenced at all by the application of a horizontal load component directed away frou the wall. This is in marked contrast to tre sensitivity of the maxima to a horizontal load component directed towards the wall face. 
4.9 OYEBALL CHANGE IN STRIP IBACTION EORCE RUE TO HORLZONIAL CEMPONENT

As has been made clear from the preceeding sections, the eftect of the horizontal load component on the gtrip traction. forces was greatly different for the two opposing directions in wich it was applied. Of turtier signlficance was the fact that although the horizontal loar components were applied In opposite directions, the effect they.had on the traction forces were not, in any way, the inverse of euch other.

However it was noted, (see Figs.4.52 and 4.53 ), that for both load directions, the relationship between the change in the strip traction force and the horizontal load component was virtually linear in most instances. Hased on this observation, this relation ship was asgumed to be linear for simplicity of further analysis of the behaviour of the reinforced earth retaining wall system under a horizontally applied load component.

It wa also noted, and is shown in Figs.4.54 to 4.57 , that this relationship between the change in strip traction force and the applied horizontal load component was independent of the masnitude of the vertical component of the load. That is to say, for both, a vertical load of $60 \mathrm{kN} / \mathrm{u}^{2}$ and $100 \mathrm{KN} / \mathrm{m}^{2}$, approximately the same change was brought abuut in the strip truction force hy the same horizontal load component, for elach value of the verticul loud. 
Hence the change in tre strip traction forcerwas interpreted la terms of the horizontal load componient only, and not in terms of a resultunt force vector.

Based upon the ubove reasoning and assumption, it is now posslole to present a practicable analysis on the effect of the horizontal load component on the stress in the reinforcing stripy. In the following aiscussion, strip traction torce will bo replaced by gtrip stress, in order to maintain consistency of the units, and so that the slope of the horizontal stress-strip stress relationshij be non-nimensional. The experimental data fór this section is presented in terms of contours. The contours are of equal values of the the slope of the horizontal stress-strip stress relationship and are thus dimensionless. The contours are plotted on a side view of the reinforced eurth model, and were determined from the slopes of the horizontul stress-strip stress relationshlps for euch strain pauge. The contours were plotted by computer, utilizing a plotter subroutine.

The contour alagams tive a very clear indication of the rexions within the reinforced parth retaining wall system whlch aremost sensitive töchunges in the horizontil load component. Furthermore they also record the masnitude of tire response of the strip gtress to changesin the horizontal loud component. 
4.9.1 Korlzontal Gemponent Dicected Touards the Yall Eace

Fixs. 4.58 to 4.63 present the contours for eacn toad location wherein the horizontal component is directed towards the wall tace.

The flrst point evident from looking ut these contour diagrams is the fact that the value of the dimensionless contours is positive throukhout the reinforced earth system, Indicating a corresponding increase in the strip stress in any point of any strip), with an increase in tre horizontal load component at all of the load locations.

The region within which the most significant increase in the strip stress occoured may be closely approximater by the active zone; as defined in section 4.3. This uppruximation holds tor load locations I, 'II, and III, and is lllustrated by the dushed lines in Fiss.4.59 to 4.62.

As may be seer by comparing the raximum values of the oontours for each loud location, the greatest increase in the strip stress is broubht about in the situation where the loud is at the wall face, and then decreases as the load is pusitioned further away from the wall face. For the load at location I, Fin.4.58, the largest values of the contours is 9,000, and this then decreases to a value of 2,000 , for the loud at location IV, Fig.4.6.3. This trend was consistent throughout plil the tests.

Hence the proximity of the load to the wall fuce has a direct effect on the sensitivity of the change in the existIng ytrip stress to the apflied horizontal load coiponent. 


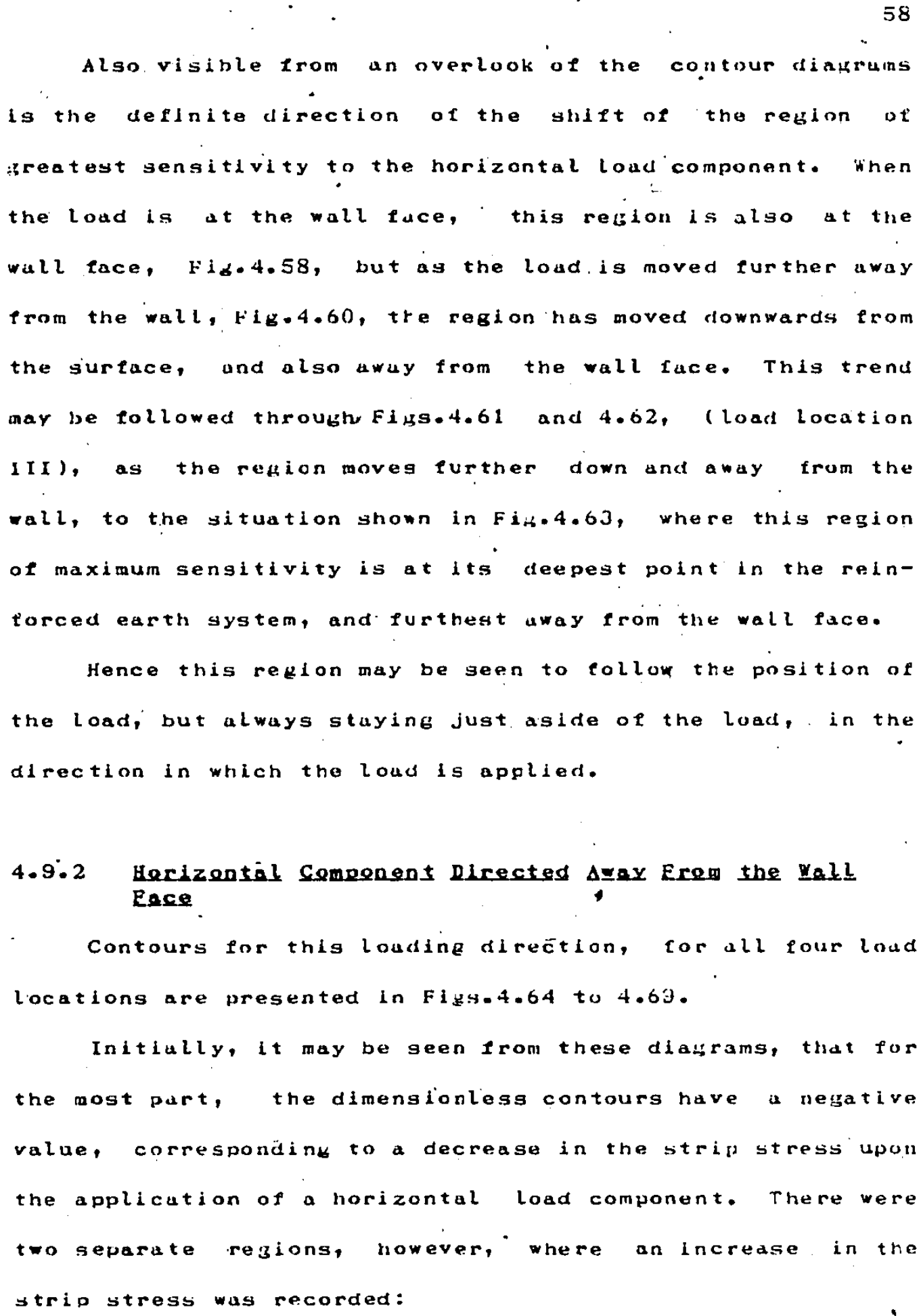

Also visible trom an overlook of the contour diarrus is the definite direction of the shift of the region of Greatest sensitdvity to the horizontal load component. inen the load is at the wall fuce, this region is also at the wall cace, Fił. 4.58 , but as the load.is moved further uway from the wall, fig.4.60, tre region has moved downwards from the surtace, and also away from the wall face. This trend mar be tollowed through Figs.4.61 and 4.62, (load location III), as the region moveg further down and away from the -all, to the situation shown in Fig.4.63, where this region of maximum sengitivity is at lts deepest point in the reinforced earth system, and furthest away from the wall face. Hence this region may be seen to collow the position of the load; but always staying just aside of the load, in the direction in which the loud ls applied.

4.9.2 Herizental comeonent Dlrected Away Ero⿴囗十 the Dall Ences

Contours for this louding direction, for all four loud locations are presented in Figs.4.64 to 4.63.

Initiully, it may be geen from these diagrams, that for the most part, the dimengionless contours have a negative value, corresponaint to a decrease in the strif stress upon the application of a horizontal load component. There were two separate regions, however, where an increase in the strip stress was recorded: 
1. In the rejion immediately under the loud, a moderate increase in the strip stress was recorderl in most tests, corresponding, to an increase in the norizontal load component. othervise a much smalier negative value of the contours was. recorded, as in Figs.4.65 and 4.66. This eftect was probably due to the loacalized efect of the load component.

2. In all tests, for all loud locations, It was observed that in the lower right hand portion of the model there uccoured an increase in the strip stress us a result of the fiorizontally applied load dompgnent. The rate of change of this increase in the strip stress is relatively small, being in the region from 0 to 1,000

The larger changes in the strip stress with, the loud. directed away,froin the wall face! were brought about when . the load was closer to the wall face, and decreased as the load was positioned further away from the wull face.

As may be seen from all the flures, there are two seperate areas within the reinforced earth medium wherein the rate of change, in this case, decrease) of the strip stress with the applied horizontal load component has is local maxi-. mum.

The flest is located in the active zoned it can be seon that for the load at the wall cace, Fiks.4.64 and 4.65 , this rekion is also at the wall fuce. As the load moves further 
away crom the wall face, this reuion of maximum sansitivity tends to move with it, as, may be seen in Figs.4.66 throush +.68 to Fic.4.69. Parallel to the inward movini trend of this refion is the increase in maknitude of its maximum contour value, from $-4,000$ where, the load is at the wall face, to a value of $-2,000$ when the load is at location $I V$. The second region is located in the resistant zone. As the load is positioned further.away from the wall faco this region moves with it, alwayg staying aside of the loud, in the direction fin which the horizontal component 19 applied. Alont with the lateral shitt of this region 1 s an increase in its value, from a value of $-4,000$ for the load at the wall face, Fis-4.64, through $-3,000$ for load location II, Flas.4.66, to a, value of $-2,000$ for the load at location IV, Fis. $4 \cdot 69$.

It is of relevance to note that thebe two regions may be roughly divided by the potentiul tailure flane, (see dashed line in Fiss.4.64 to 4.68). This is the line alons whlgh, as discussed in section 4.6 .2 , the smallest decrease occours under a horizontàl load component beingi directed away from the wall face, and ls due to the formation of a potential failure plane.

.

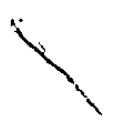




\subsection{EREECT OE HOBVZONTAL SONPONENT ON BEHAYIQUYK OE YALL} EACE

Firs. 4.70 to 4.77 present the wall deformation under

the vertical loud and un an increaging horizontul load, for the horizontel load component directed both towards und away from the wall, tor all four load locations.

The case with the horlzontal load component directed. towards the wal face is fregented in the first four figures. The breatest increase in the wall detlection occours when the load is at the wall face, Fig.4.70, as can bo seen from the larye deflections, especially in the upper hulf of the wall, for a horizontal loud component of $10 \mathrm{KN} / \mathrm{m}^{2}$ For the load at location II, Fla.4.71, the deflection at all levels has reduced, despite the larger horizontal load components up to $26 \mathrm{KN} / \mathrm{m}^{2}$. The amount of deflection further reduces for the load at location III, Fig.4.72, to those for load location IV, Fig.4.20. It should also be noted, as is evident from the diagrams, that although the horizontal load component increases in constant intervals, the wall doflection increases in ever-increasling intervals. So, any further deflection of:the wall due to the horizontal load component directed towards the wall face is dependent on two parameters:

1. The manntude of the horizontal load component, and 2. The proximity of the loud to the wall face. .......... This latter parameter, and the. mugnitude of: any existing horizontal component determine the sensitivity of the wall deflection to ine horizontal had component. 


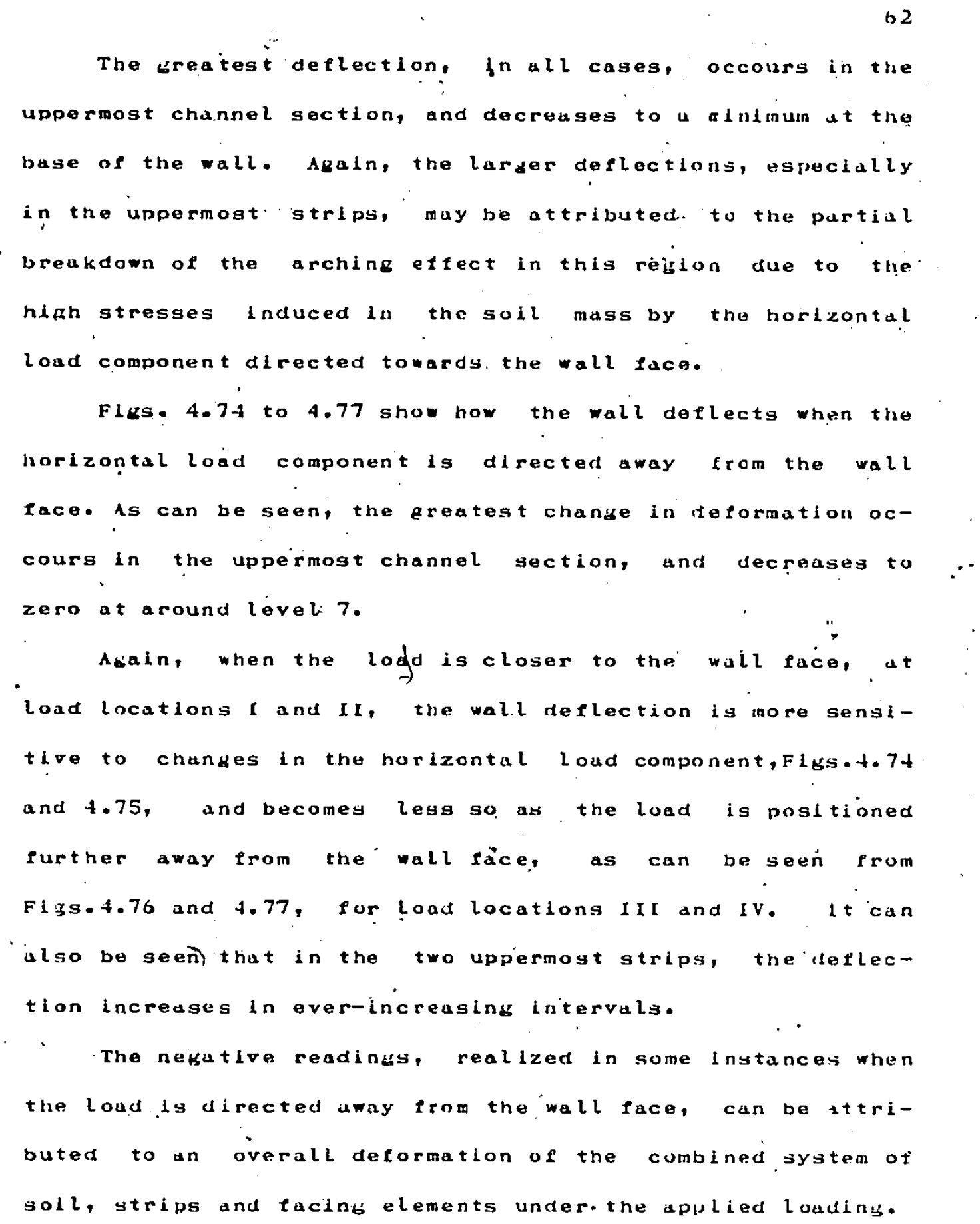




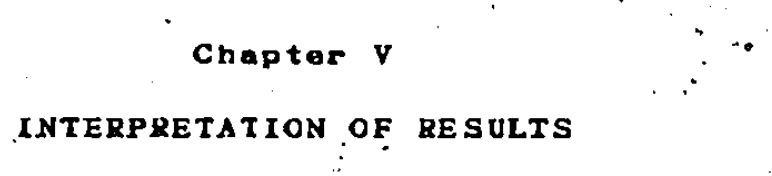

\subsection{YOBLLIZED SQIL-SIRIP ERICTION}

In order to rake un estimate of the degree of soligtrip friction moblizized at each reinforcement level, certain assumptions. must be made as, to the state of stress within the reinforced earth system. Thesb asgumptions are llustrated in Fis.5. $\dot{1}$, and are:

1. The vertical stress wihln the reinforced earth mass due to the surcharge load ls distributed according to the 2:1 dispersion lines convention. Within this reglon the vertical stress varies only with depth. outside it the vertical stress is zero.

2. There is a lineár boundary between the active und re- slstant cones. Ihis boundary is the straight line joinind the base of the wall. to the inside edye of the strip. toad.

- If the portion of the reinforcing strip which lies buth in the resistant zone and. Within the $2: 1$ dispersion lines is considered as a free-body. Fif-5.2, from a consicleration os sfatic equilibrium, the shear stresses, $\tau$, "acting along it in the direction away from the wall must ërual the maximum. traction force, $T_{\max }$, which acts at the boundary between the $-631$ 


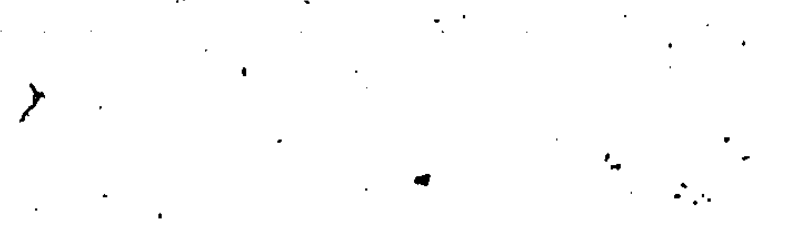

activie and passive zones. The,force equilibriun equa'tion. for this pree-body is:

$$
T_{\max }=\sigma_{y} \cdot 2 b \cdot \Delta l \cdot 1
$$$$
\text { -..5. } 1
$$

where i is thé actual coefficient of friction dobilized between the foil and the strip. This coefficient of friction inut always be less than or equal to a maximim value of $\tan 40^{\circ}=0.84$, (this maximum value is the internal eriction angle of the sand used in the experimental work), us sand - had been glued to the strips. If the coefficient of friction is preater, slippage of the strips witnle the sand would have occioured.

$\therefore$ Every termin the above equation, except 1. may be determined at each level: $\sigma_{y}$ and $\Delta l$ fromithe ibove twó assumptions, and $T_{\max }$ frop the experimental results. This onablos a value or $F$ to be determined a't every. level.. Figs.5.3 toj 5.6, plot. the values of $t$, calculated from the above equation, as, a function of depth, for the load at locations $x$ to IV respectively. The values of the eriction coetfocient are presented in Table 5.1 .

As mentioned, the maxlmum value of $f$ is 0.34 . Inis value is exceeded at levels 2 ind $3^{\prime}$ when the load is at location. I. This indicates that slippage has occoured between - the joil and the strip at these levetgo from level t dawn, the triction between the scli and the istrips decreases conti:nuous ly. 
For the load at location 11 , the valise of friction nobilized increases to a maximum, value of 0.76 at level 3 , Fil.5.4, and decreases thereafter with depth.

Fopr load locations III and IV, Fits.5.5 and 5.6, the values of determined at each gtrip level are less for luad location IV than those determined for load location III..

The values of $t$ determined in the above munner are proportlonal to the measured"values of $T_{\max }$. If the density of relntorcint strips were dreater, the meusurad values of $T_{\text {max }}$ would be smallyr, and accordingly, the values ot $f$. However the results shown in the figures also indicate the trend of the mobilized soil-gtrip triction, which will be the same lrrespective of strip dengity.

It is evident from a consideration of the above infiormation that under a surcharge strip load, the region close to the surface of the reinforced earth, medium is the region whpein fallure of the gystem by lack. of adberence between. the soil and the reinforcing strips is most likely. to ocicour.

However, when the hoad is at the wall face it is the very uppormost gatripg which are likelty teglip; due to concentration of stresses in this region.

Further down from the surface, the friction molsililed $\therefore$ reduces, and this aspect of the desian becomes less critical; now the seli weluht of the suil becones the governiny design factor. 
1

66:

\subsection{YAXIYUX IBACTICN EQRCE AS A EUNCIIQN QE REPTU}

. An estimation of the maximuin traction force in a reinforcing strip is given by kenneay et al.,(10). Inis is a motification of Terzaghi's formula for the computation of the latoral pressure against a conventional risid retaining wall:

$$
T_{\max }=(2-k) \cdot \dot{q} \cdot(\beta-\sin [\beta] \cdot \cos [2 \alpha]) / \pi \quad \ldots .5 .2
$$

where q is the strib loda, $\alpha$, wnd $\beta$, ws detined in $F i j .2 .1 i j$, and? is reduction factor based upon the stitfness characteristics of the backfill material and the strias:

$$
R=\frac{A \cdot E_{t_{\text {backfill }}}}{A \cdot E_{t_{\text {beckefil }}}+A \cdot E_{t_{\text {strips }}}}
$$

$\because$

Where Et dackill is the tankent modulus of the backitil. Duncan and Chans( 3 ), jive arr expression fur this turioent lassulup:
$\quad E_{t}=\left[1-\frac{R_{f} \cdot(1-\sin \phi) \cdot\left(\sigma_{1}-\sigma_{3}\right)}{2 \cdot c \cdot \cos \phi+2 \cdot \sigma_{3} \cdot \sin \phi}\right]^{2} \cdot k_{0}^{\prime} \cdot p_{a}\left[\frac{\sigma_{3}}{p_{a}}\right]^{n}$

where. $\sigma_{3}$ und $\sigma_{3}$ are the major and minor arincisle stresises -respectively; $K$ is the fallure ratio:

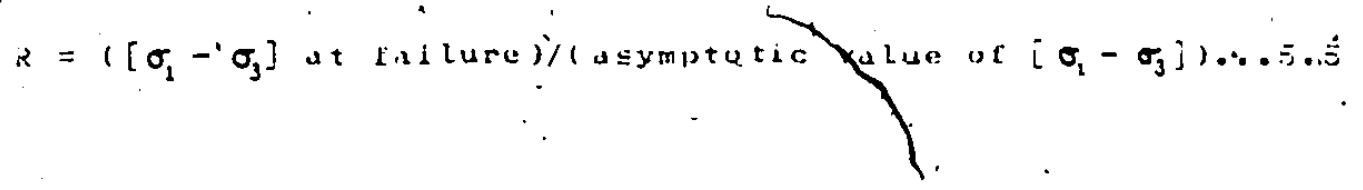

1. 
$k^{i}$. Is modulus number; $n$ is an exponent cetermining the rate of varation of the initial tunjent molulus witn $\sigma_{3} ;$. Fa. is atinospherite pressure; $\phi$ is internal soil friction, und $c$ is. soil cohesion.

Kennedy et al. rejlaced $\sigma_{2}$ and $\sigma_{3}$ with $\sigma_{v}$ and $\sigma_{N}$, the vertical and horizontal stresses due to the surchirge strip load and weinht of the suil soil backfill:

$$
E_{t}=\left[1-\frac{R_{f} \cdot(1-\sin \phi) \cdot\left(\sigma_{v}-\sigma_{k}\right)}{2 \cdot c \cdot \cos \phi+2 \cdot \sigma_{n} \cdot \sin \phi}\right]_{, \sim}^{2} \cdot K^{\prime} \cdot P_{a}\left[\frac{\sigma_{k}}{P_{a}}\right]^{n}
$$

and use this expression to calculate a value tor the tungent nodulus of the suil backfill. However in doing so the dilthars use vilues of $\sigma_{V}$ and $\sigma_{H}$ which correspond to ilven. Lodding conditions on the reinforced earth medium (i.e. the soil backfill with the reinforcint strips). The value obtained for i $E_{t}$ consequently is not the tankent modulus of tre - soil backfill ulone as stated in equation 5.3, rather it is representative of the combined media, and as such is incorrectly used in equation 5.3 , which is based upon the different stiffness characteristics of the copbined redia. Furthermure, by using these values of $\sigma_{V}$ and $\sigma_{H}$ in , eruation 5.5 , the term

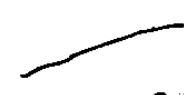

$$
\therefore\left(R_{F} \cdot\left(\beta_{j} \sin \phi\right) \cdot\left(\sigma_{v}-\sigma_{n}\right)\right) /\left(2 \cdot c \cdot \cos \phi+2 \cdot \sigma_{k} \cdot \sin \phi\right) \text {. }
$$

can offen be preater than unity. However, the maximum iossiblo value ot this term is unity, as it is the ratio bi ins? 
existlnk value of $\left(\sigma_{n}-\sigma_{n}\right)$ in the soll to the asymptotic value of $\left(\sigma_{y}-\sigma_{k}\right)$, and failure will have taken place if it is $\geq 1$. The uuthors state that il this term $\geq 1$, then $E_{t}$ is to be tuken as zero.

Following the above premise, $K$ will be equal to zero under certain loading conditions, and this will cause discontinuities in the distribution of maximum traction, forces with depth. These discontinuities can be seen in Figs.5.7 to 5.10, whlch present values of $I_{\max }$ calculated from equation 5.2, for the different loads and different load locations. values of $k, K^{\prime}, n, c$ and $\phi$ for a cohesionless backell are taken from Al-hussaint and Jahnson( 2 ), and are: $k_{f}=0.85$; $\mathrm{K}^{\prime}=580 ; \mathrm{n}=0.5 ;$ for $\mathrm{c}^{-}=0$, and $\phi=30^{\circ}$.

Furthermure, a compartson may be mace between these uraphs and the actual measured values of the auximum tractiun force as a function of repth.

Fig. 5.11 shows experimentally measured values of $T_{\max }$

on a Hraph of the values of $I_{\max }$, calculated from equation 5.2 , for load location I. Figs.5.12 to 5.14 present measured and calculated values for the'load at locations II, III and IV respectively.

It can clearly be seen from these comparisons, that the closest correspondence between the experimental and theoretical results occours for the load at location IV. As the Loud is positioned cluser to the wall face tre difference. between the theuretical and experimental resiuls vecomes nuch lariger.

$$
\text { . }
$$



5.3 STRESS DISTRIBUTION DUE TO BORLZONTAL LOAD CONPONENT

The stress distribution occouring ln the ${ }^{2}$ soll backill due to the horizontal load component ady be deduced from the horiziontal load component-gtrip stress contours. This is uchleved hy considerinu a unlt element of the reinforced earth medium, Fis.s.15, under an adilitional lataral stress $\Delta \sigma_{N}$, actine on the plane $A B C D$; assuming that this extra lateral stress is taken up by the reinforcing strip, then tre tollowing equation of equilibriur may be written:

$$
\Delta \sigma_{H} \cdot d s . d h=\Delta \sigma_{2} \cdot A
$$

where $\Delta \sigma_{g}$ is the, additional strip stress, and $A$, is the cross-sectianal area of the reinforcinis strip. bividing both sides of the above equation by 11 , the lncrement of the horizontal load component, ibives:

$$
\frac{\Delta \sigma_{m}}{\Delta \mathrm{H}} \cdot \mathrm{ds} \cdot \mathrm{dh}=\frac{{\dot{\Delta \sigma_{f}^{\prime}}}_{\Delta \mathrm{d}} \cdot \mathrm{A}}{\cdots .5 .7}
$$

which can be witten as:

$$
\frac{\Delta \sigma_{n}}{\Delta \mathbf{H}}-\frac{A}{\mathrm{ds}, \mathrm{dh}}: \frac{\Delta \sigma_{\mathbf{g}}}{\Delta H}
$$$$
\cdot \ldots \cdot 5 \cdot 8
$$

where $\left(\Delta \sigma_{3} / \Delta H\right)$ is the ratio of change in jerip stress to chanse in the horizontal load component, presonted in Fins.4.54 to 4.65. $\left(\Delta \sigma_{H} / \Delta H\right)$ is.the ratio of the cuange in the soil soil stress to tre change in the horlzontal load component. Contours of these values are presented in Flis.5.16 to 5.18, for the load component directed towards the wall race. i: 
The type of stress distribution proposed by the french Ministry of Transport(20), which is used for destan purpouses, 13 shown in Fig.2.11. Thelr approach proposes an additional horizontul. stress component acting it riaht angles on a vertical plane through tre centre of the loaded area. The maxiaun additional stress occoursat the surface, and decreases linearly to zero at a depth $h$, which is given only as a function of $\phi$, the ungle of internal soil friction. This stress distribution is assumed to occour only along the vertical plane through the centre ut the loaded area.

Figs.5:19 to 5.21 show the stress distribution slonis this plane, as taken from the contours of Fiss.j.10 to $5.13 .-$ As can be seen this distribution has its maximur value beiow the surface, the depth of which is proportional to the distance of the load from the wall face. It may also be seen from fiag-5.16 to 5.18 that the region of iseatest sensitivity to the horizontal load component lies somewhat to the side of the centreline of the loaded region, in the direction In which the horizontal component is directed. Thus the French finistry of Iransport err in assuming that the muximum addltional stress due to the horizorial load component occours immediately under the centre of the loaded area. Poulos and Davis(22), Hive the following expression for the horizuntal otress induced in a semi-infinite elastic medium under an infinite horizontal strip load, Fi:-5.24:

$$
\sigma_{N}=(H / \pi) \cdot\left(\ln \frac{R_{1}^{2}}{R_{2}^{2}}-\sin \alpha \cdot \sin (\alpha+28)^{-}\right)
$$<smiles>[CH]S[SiH3]</smiles> 
The solution for this equation is presented in dimensionless form in,Fig.5.25. It can be seen thut the maximum stress occourg imediately under the edge of the loaded areu. This distribution is in closer agreement to the observed results than the French epproach. However 1 it gill assumes that the maximum stress occours at the surface. The resion for the maxinum not occouring close to or at the surfacelin the"experimental work may be jugtiflud by the fact that the load acts very close to a boundary, the wall face, (not accounted for in equation 5.9 above). The relatively larie derlectiong in the upper part of the wall, (see Figs.4.66 to 4.68), have the eftect of relaxing the large gtresses induced by the horizontal load component in this region, hence the maximum value occours not at the surtace, hut at a certain depth beLow the surface.

Furthermore, the French approich does not consider the case where the horizontal load component is directed away erom the wall face. Contours for this situation are presented in Fig3.5.22 and 5.23. In this case there ure two separate rekions within the reinforced earth ins su which are songitive to the horizontal load component, one at a certaln depth below the load itself, and another to the side of athe $\because *$ loud, in the direction. in which the load is directed. Of. The above contour diagrames may thus be used in calcus liting the additional stresses induced in the reinforcing. strins due to a horlzontal lcad component on any reinforced 
$n$

earth retaining wall gyster, as they are independent of the crosi-gectlonal area uf tho gtrips, and the dengity of the strips within the aranular backill.

6.

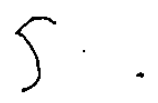

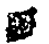

$m$

$\because \therefore$
$\therefore$
$\therefore$

1 


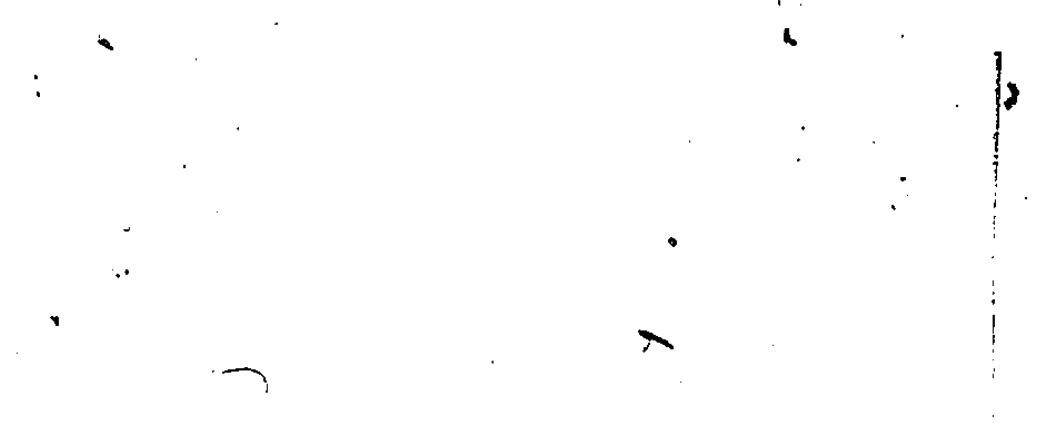

Chapter VI

CONCLUSIONS AND RECCMMENDATIONS

\section{1 concrusIONS}

based on the experimental and analytical work presented in this thesis, the following. conclusions may be made:

1) Under vertical loading conditions bionly, and fine any. given magnitude of vertical laad, the most critical loud/position observed was that at the wall face, i.a. at this position, the.largest stressey in the strips and the lirsest cetormation of the wall werelgbtained.

2) Culmann's araphical method for deterinining the position of the fallure plane hag cloge aureellent with the experimentully observed plane, tor loads within the $+\bar{p}^{\bullet}+\phi / 2$ Kankine active wedye. Outside this rejion, Culmann's solution is not reprgsentative of the observed results. 3) Leagurements of the wall daformation allowed as sint. ple determination. of the desree to which the breakdown in the archinz effect occoured under the strip loading surcharye. The extent of this effect was in direct propurtion to the stress induced in the reinforced earth mass by the surcharae load.

4) The change in the strip stress due to the horizontal, Load component may be assumed to be independent of trae was- 


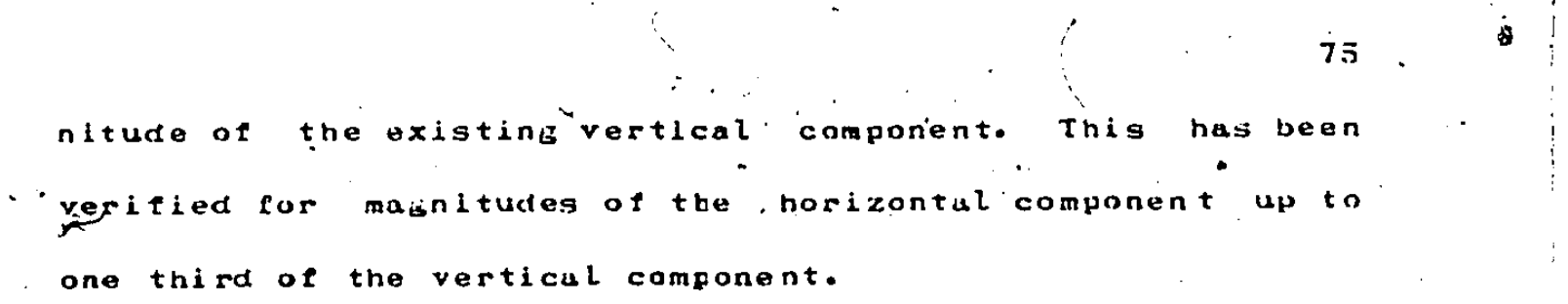

5) A horizontal load component directed irowaros the wall face has the effect of decreasing the factor of sofety. with respect to tensilo tailure of the relnforcement.

6) A horlzontal loud. component directed away. from, the Wal face bas an overall effect of decreasing the strip traction, force; except the values of maximum traction force, which are not signlficantly affected by the apjication óf the horliontal load component away prom the wall face.

7) The upper region of the reintorced eurth retaining wall most fully mobilizes the coefficient of soil-strip friction. Hence it is the most critical region with respect to failure due to soil-strip slippase under the effect of a surcharge strip load. At preatar lepths the sele welight or the backfill soil mags takes over as being the the more important lactor in design considerations.

8) Tfí method proposed by kennedy et al. (10) for the distribution of raximum traction forces. under a vertical load only, has gond agreement with the experimental results... only when the load is located outside the region defined by the $+\vec{J}^{\circ}+\phi / 2$ kankine active medise. At distances ciuser to the wall face, the proposed distribution of maximum traction $\therefore$. . . . forcog with depth leparts increasingly from the observed vaLues,. being derestimating the upserved values in the lower rejion. 


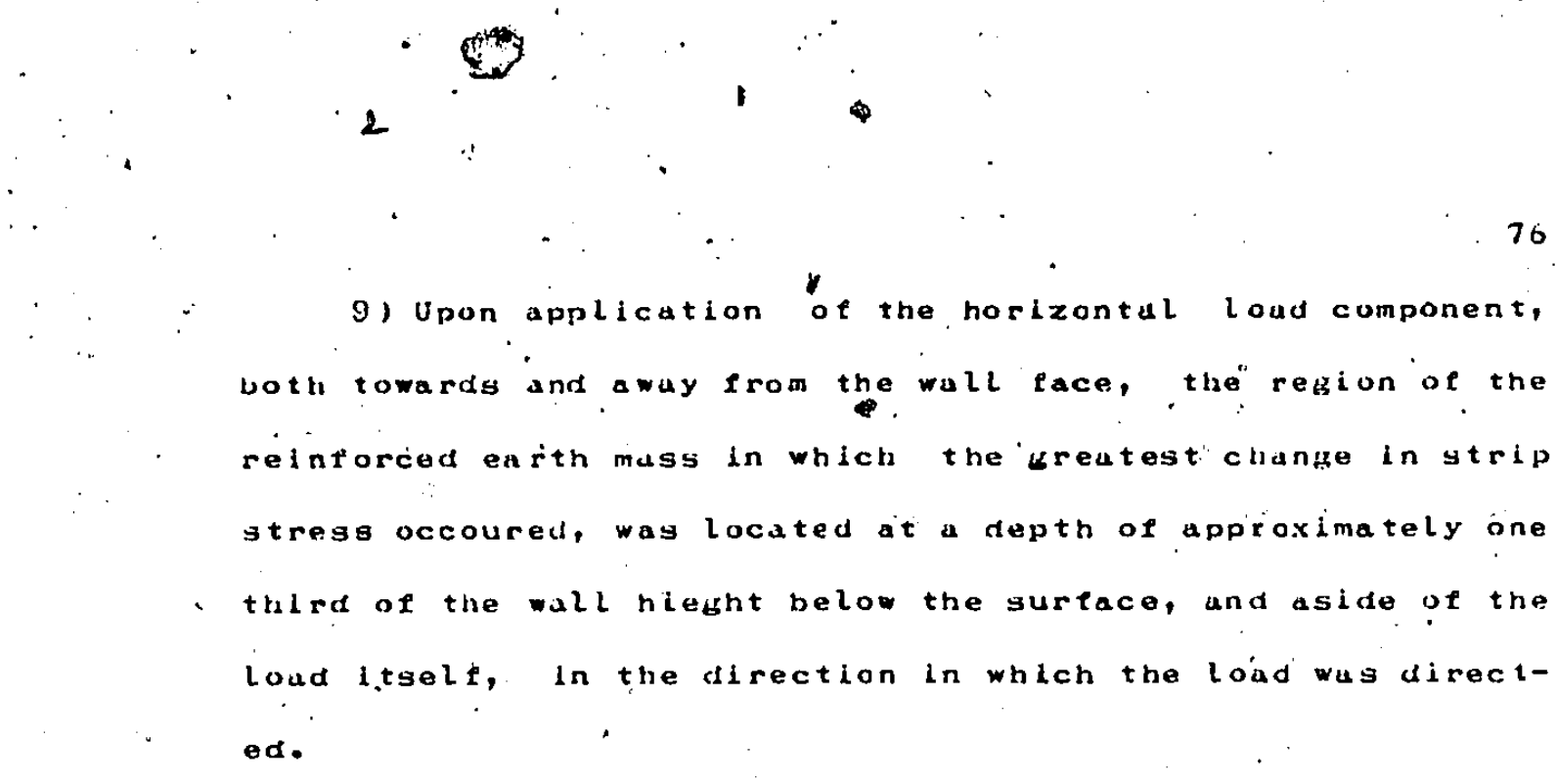

\subsection{RECOKMENRATICNS EOR EORTHER 'RESEARCH}

1) Pressure cells could te placed withln the reintarced'. enrth mass to determine the horizontal and vertical goll stresses. This would shed light upon the assumption used to determine the solil stress distribution from the strip truction force.

2) It would be helpful to determine the the traction torcendstribution due to. a vertical surcharpe loud on a semi-inflitite reinforced earth mass - ith the same properties and strig density as used in the model. This data could then be comparod to the distributions obtainedin the retaining wall model to determine more speciflcally the effect of the proximity of the load to the wall face on the mobilized strip traction force.

3) Photoelastic studies of a lod positioned near tre edpe of a finite elustic theniun (reprosenting; a loul near the edge of a reinforced earth retaining wall), wuild shed light upon the stress digtribution clueito a verticul and a norizontal load.

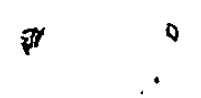


77

4). It would be worthwhile to perform similar load, tests on a model wall, but with varying strip footing widths, in order to establish the effect on the strip traction force, especially. with respect to a horizontal load component: - 5) The effect of a repetitive or alternating horizontal load component is moth investigating, as this type of loading is - Likely to occur one the reinforced earth retaining wall is used as a bridge abutment: 


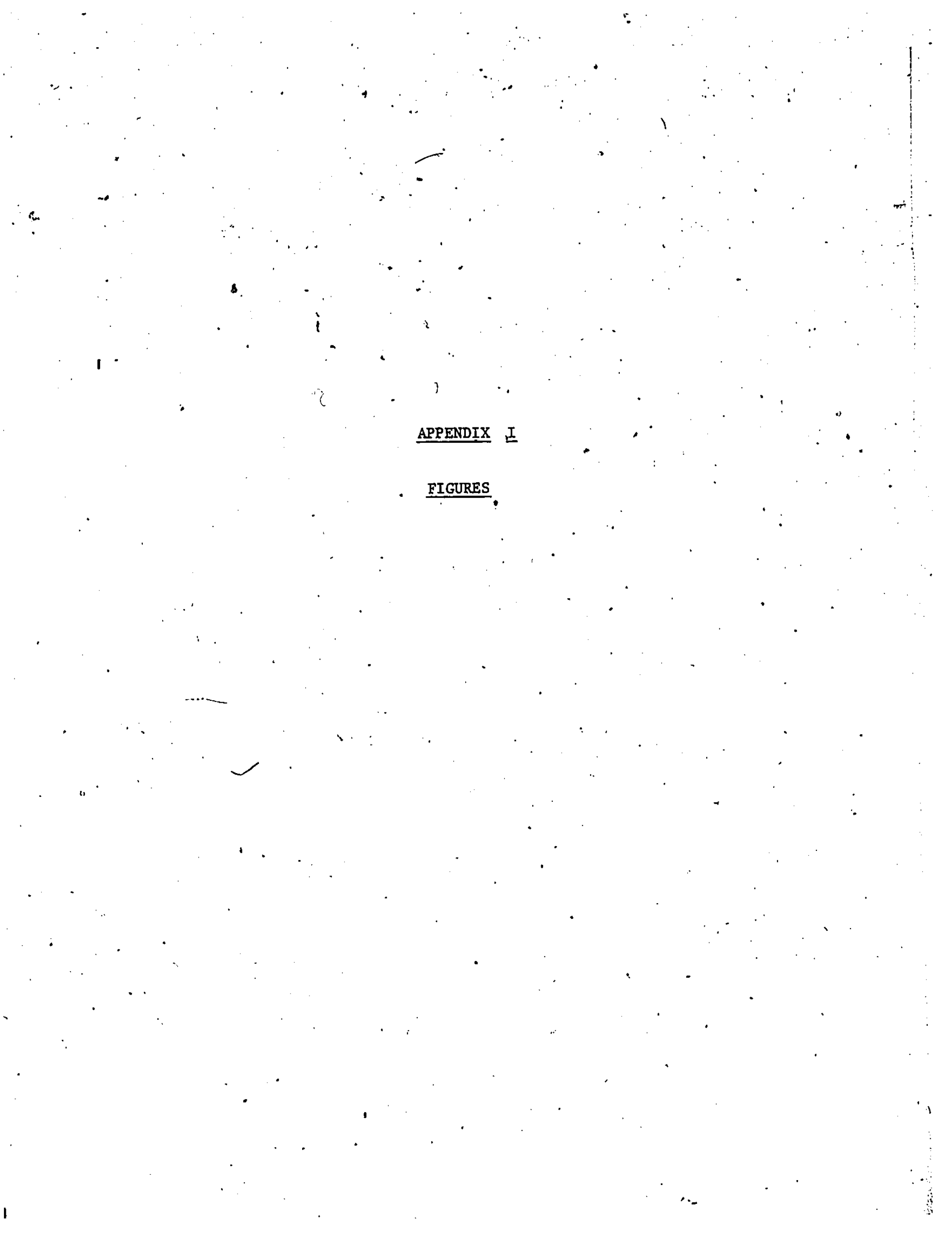




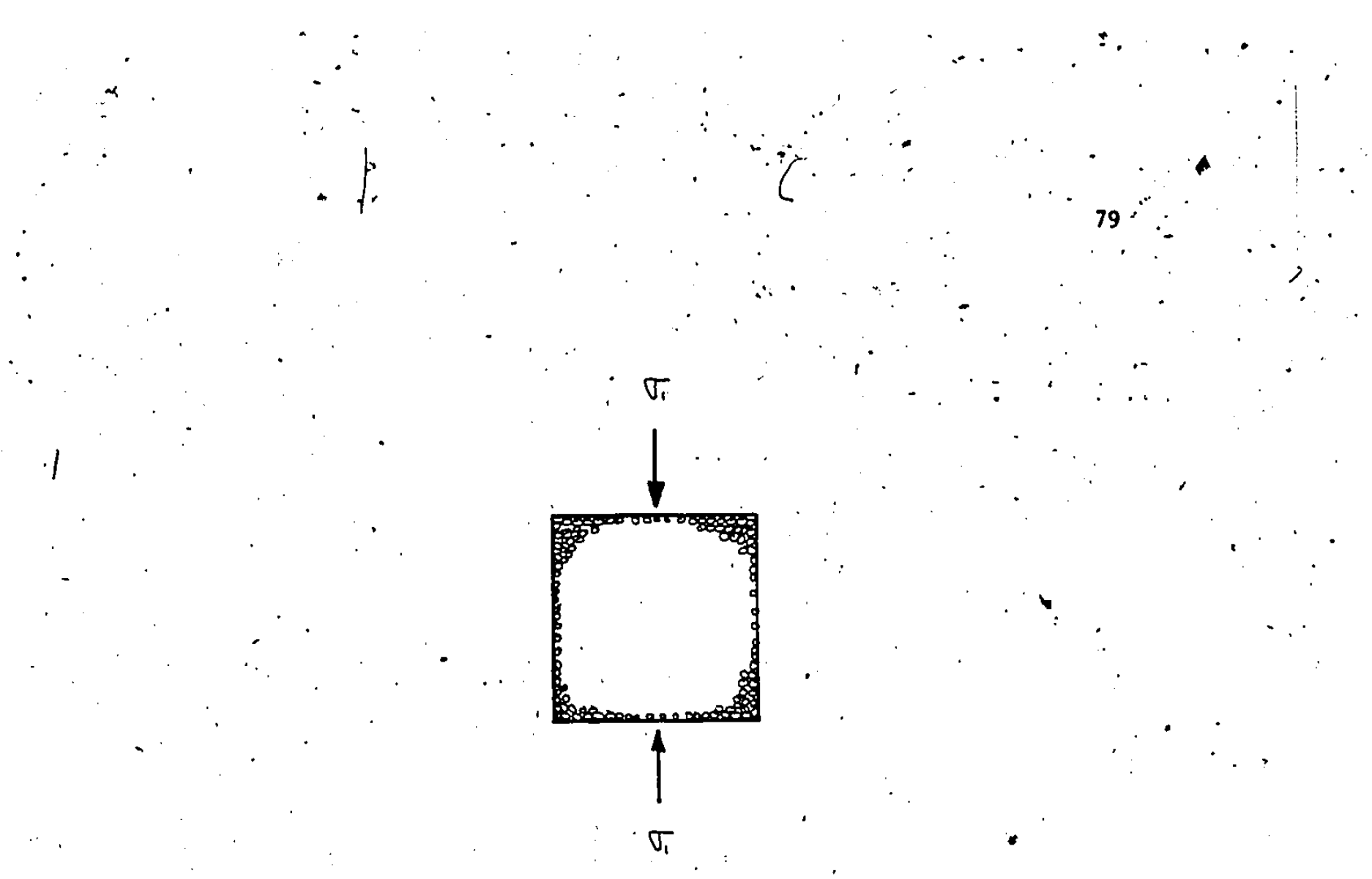

F1g. 2.1 Elementary Cube of Unreinforced Earth.

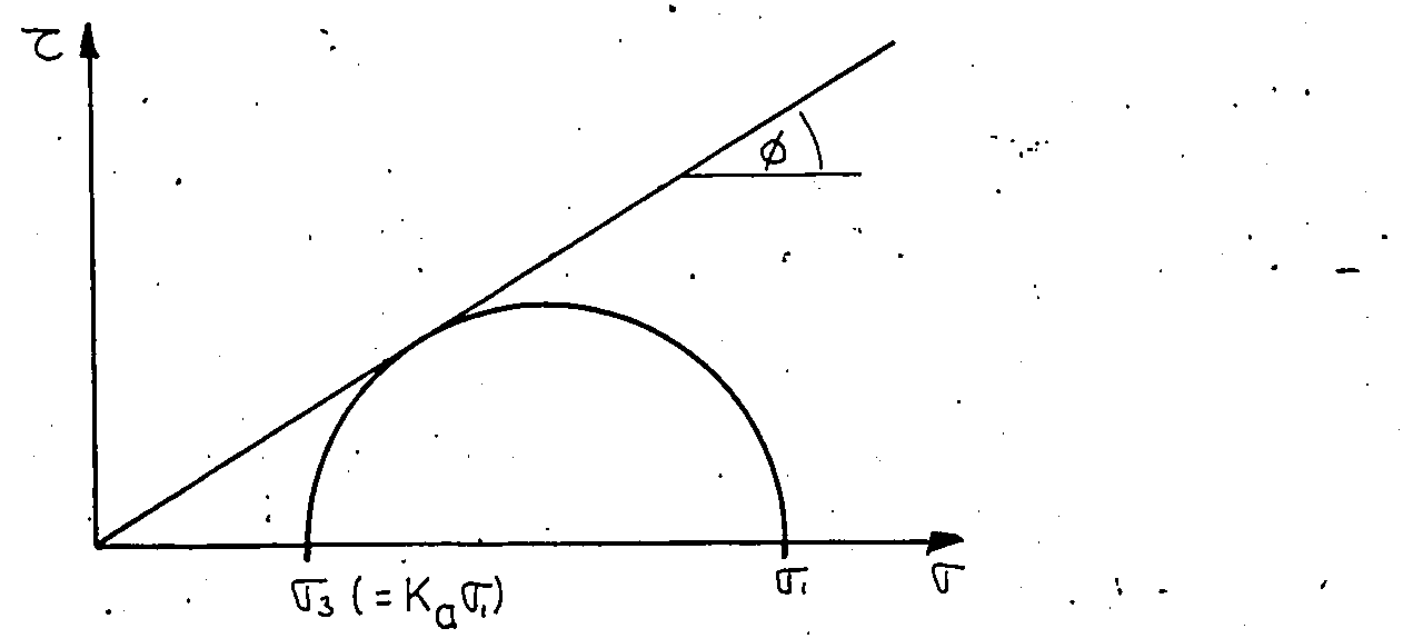

Fig. 2.2 Mohr's Circle of Stress, and Fallure Envelope' for the Soil.

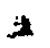

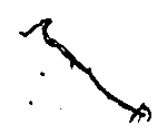




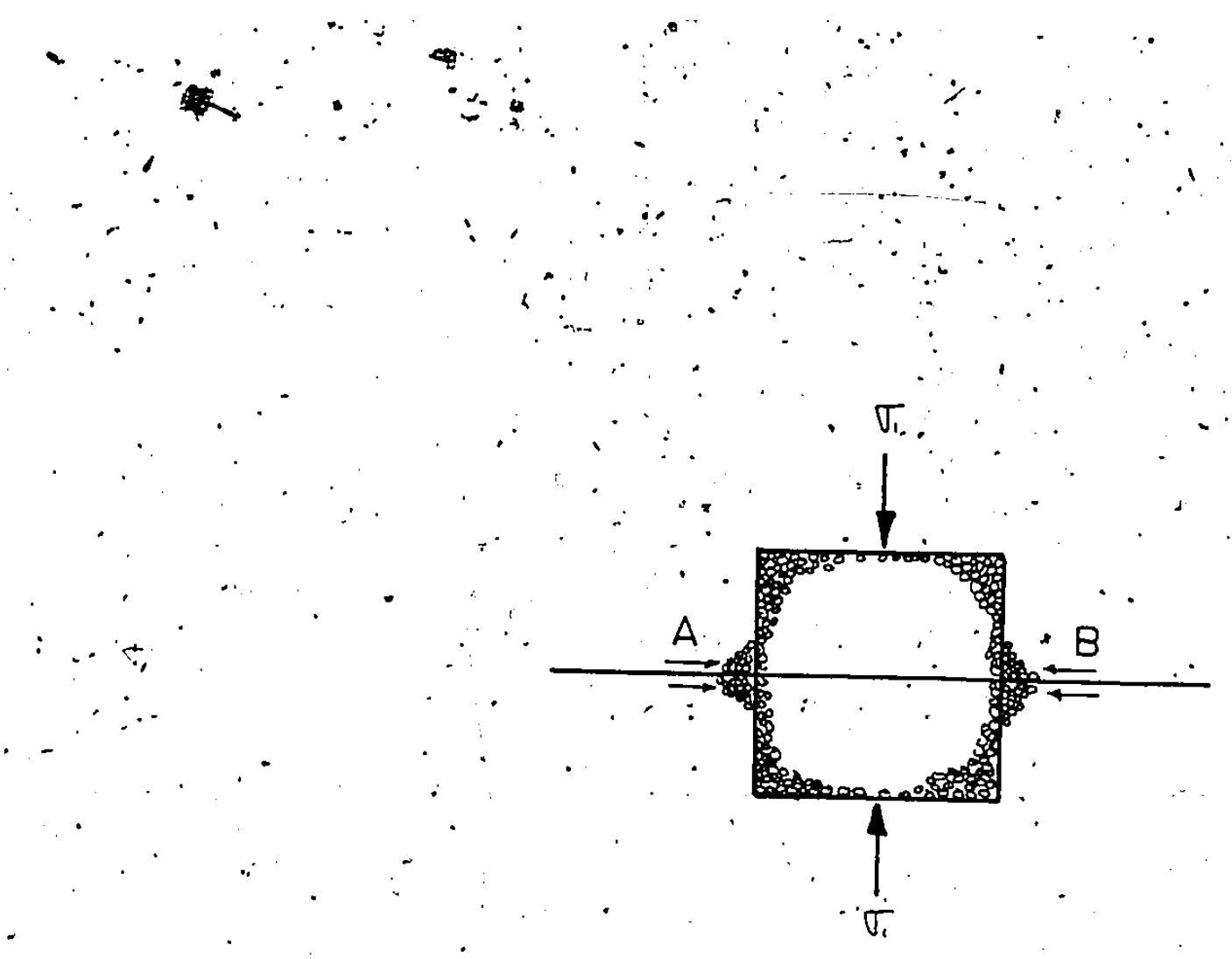

F1g. 2.3 Elementary Cube with Reinforcement.

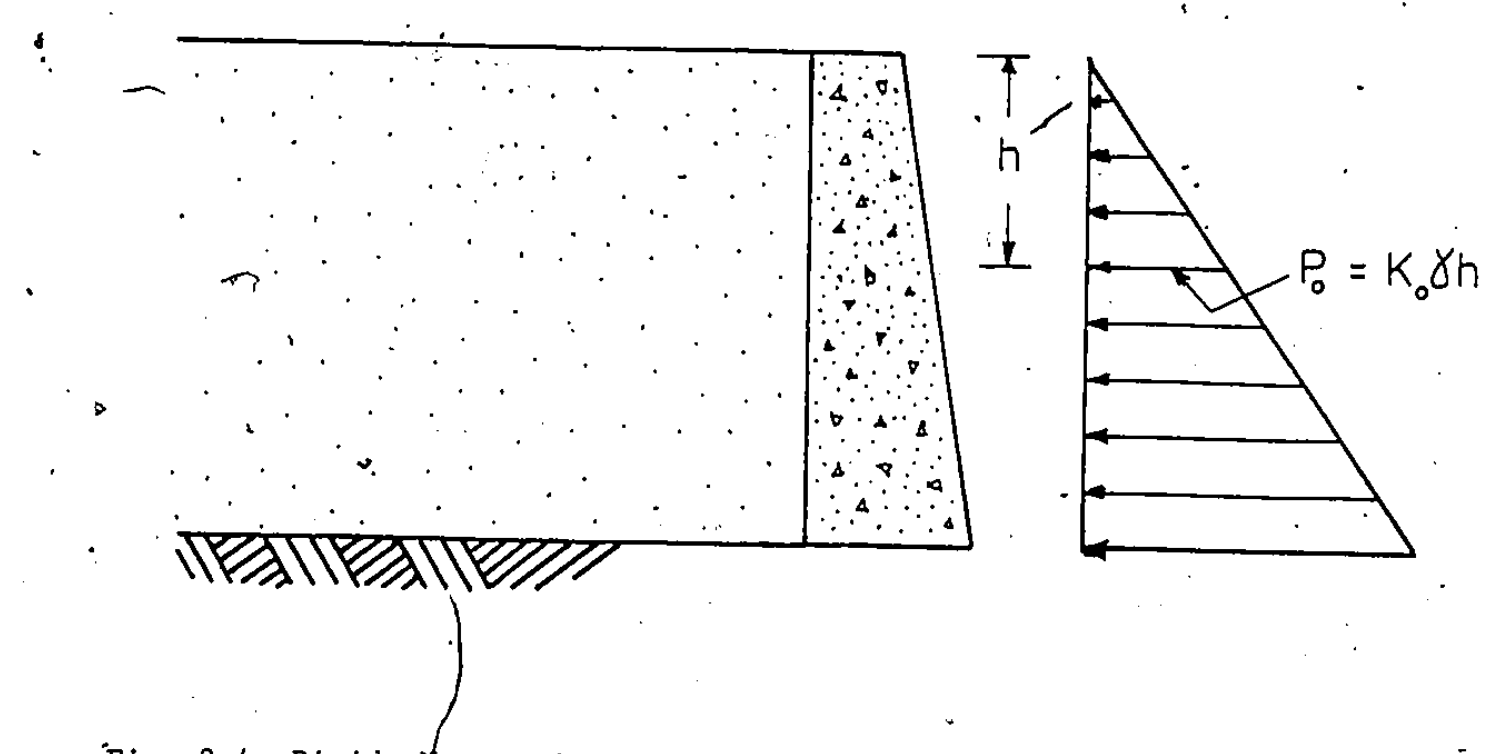

Fig. 2.4 Rigid, Non-moving, Retaining Wall, Suppourting Granular Backfili in the At-rest condition. 


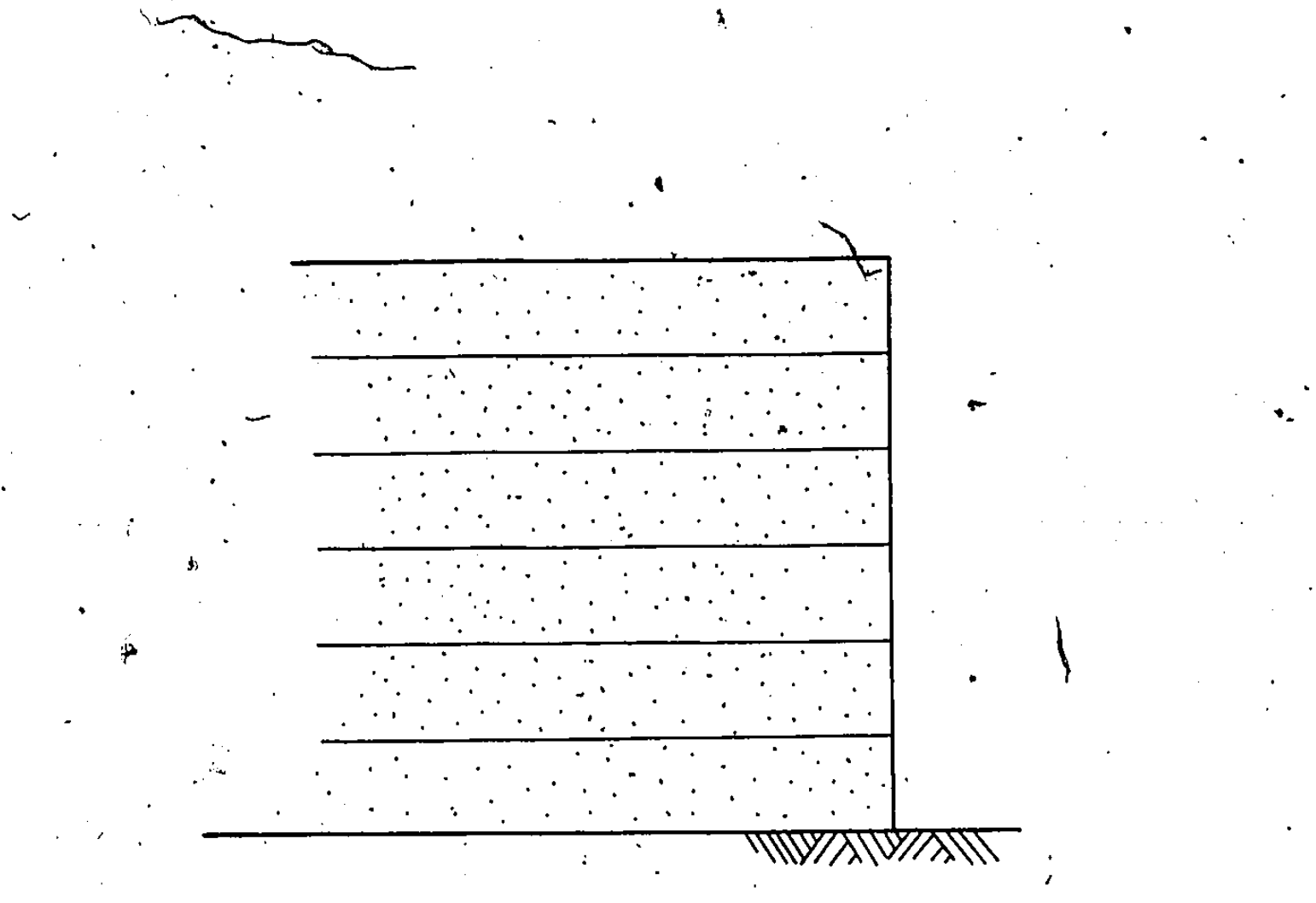

.

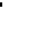

Fig. 2.5 Sol1 Mass Reinforced with Reinforcing Strips.

$+$

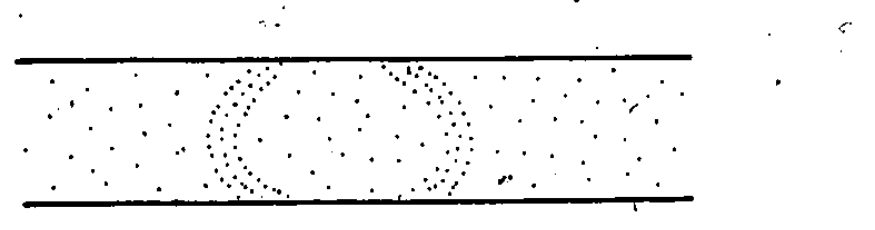

F1g. 2.6 Schematic View of. the Arching Effect, Between the Strips. 


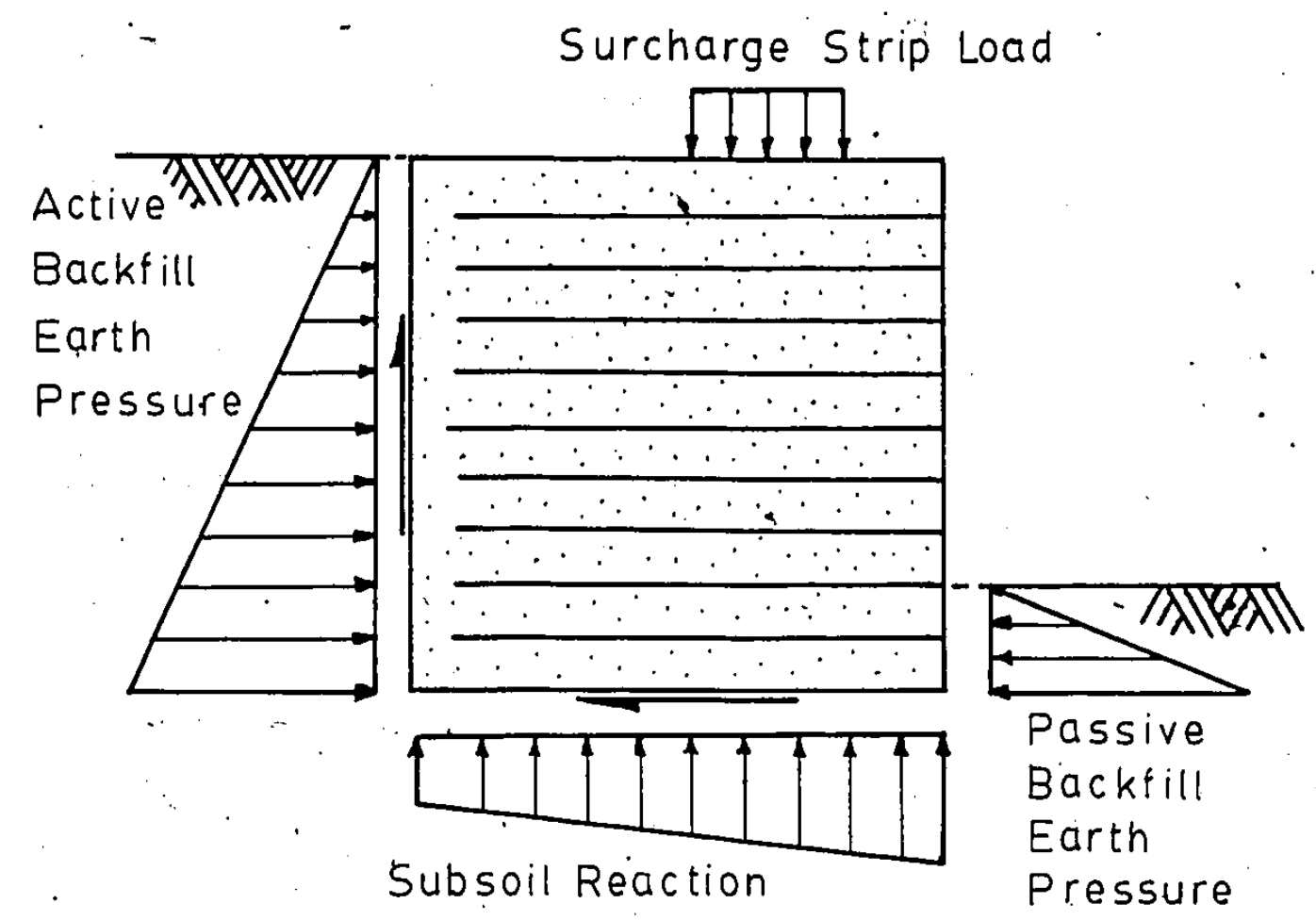

Fig. 2.7 External Loads on the Reinforced Earth Retaining Wall:

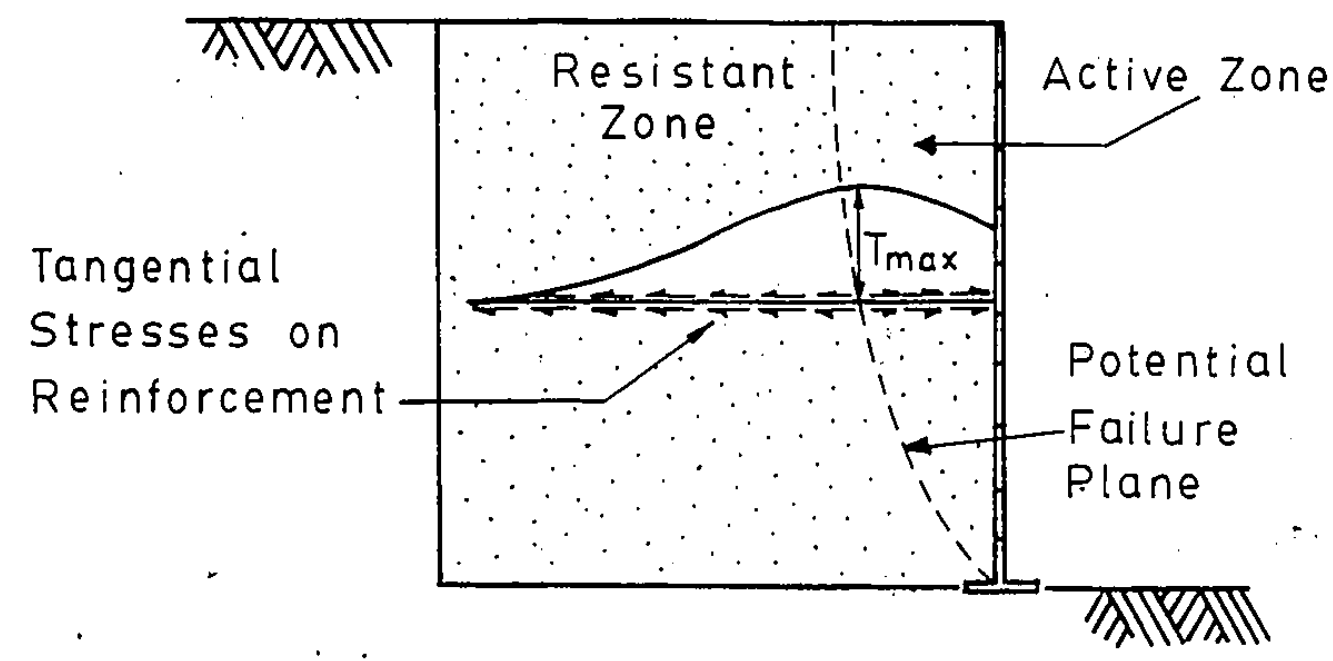

- FIg... 2.8 Stresses Exerted on the-Retnfotcement by the Sol1. 


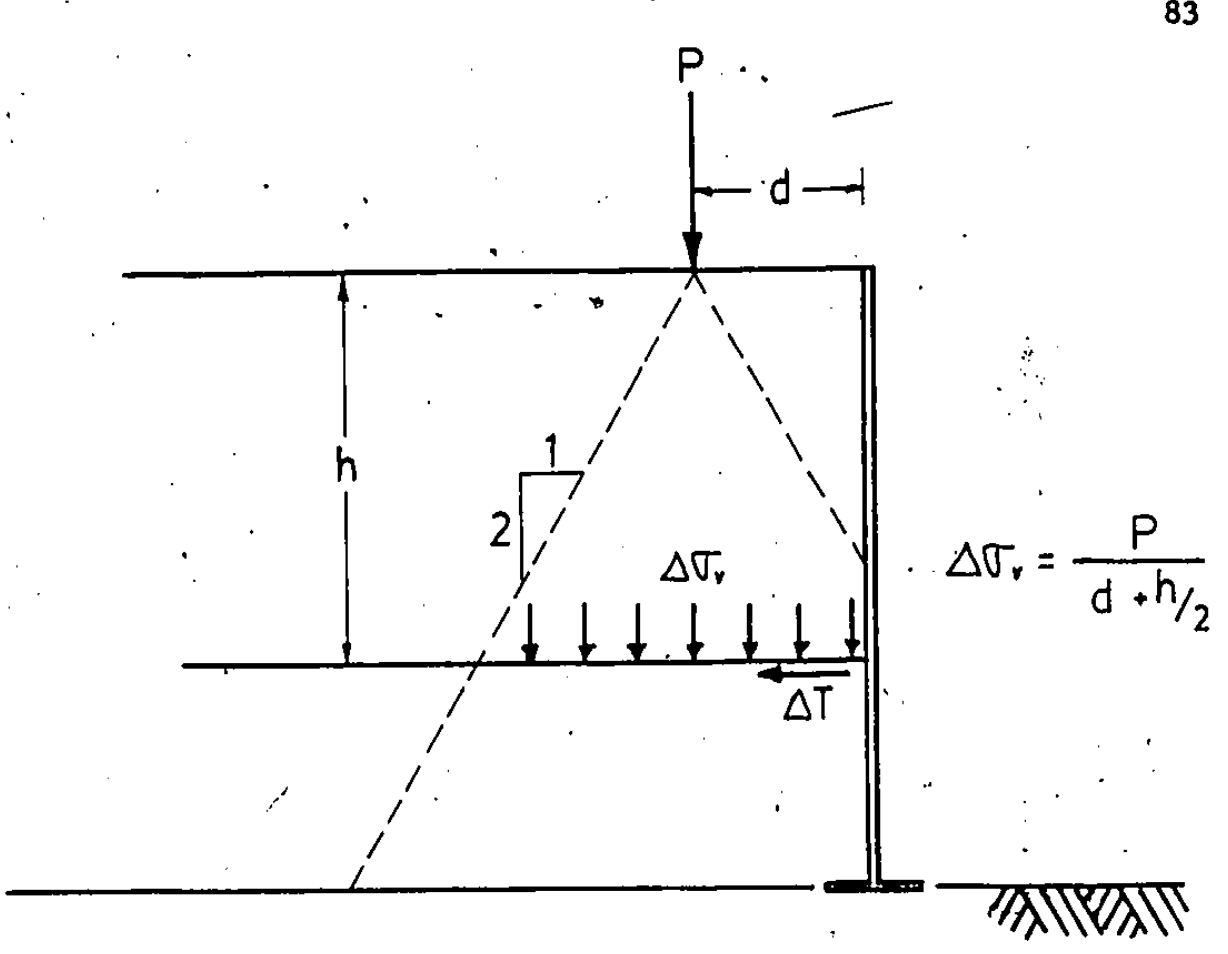

Fig. 2.9 Distribution of Vertical Stress due to Surcharge Load.

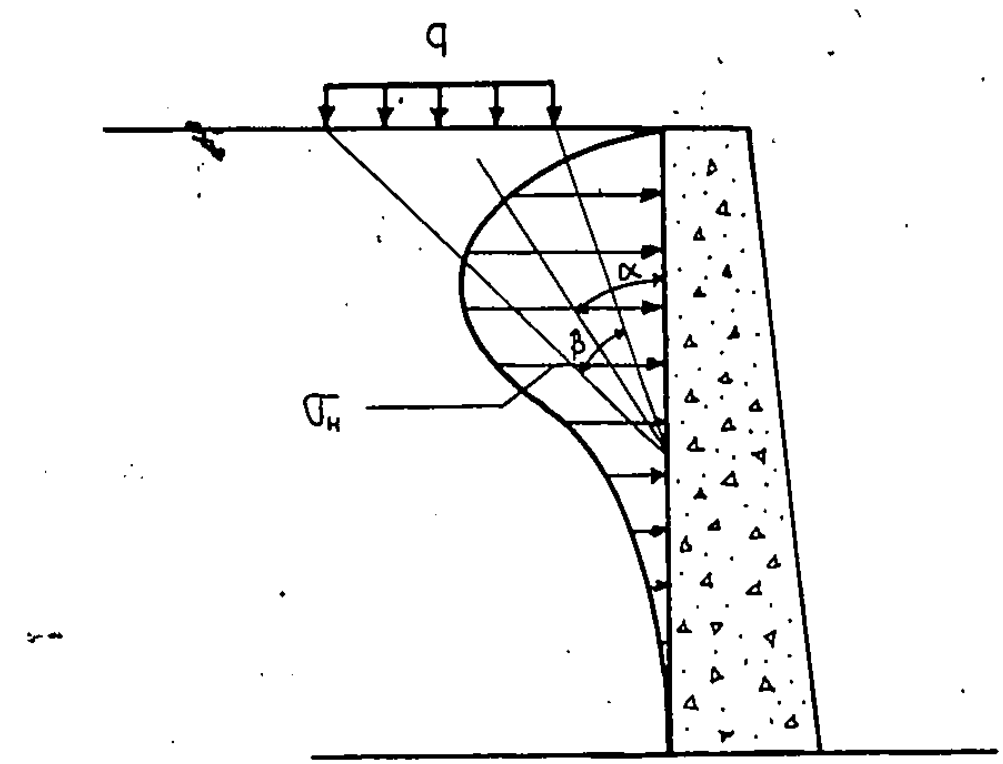

Fig. 2.10 Distribution of Horizontal Stresses Against a Rigid, Vertical Retalning Wall due to a Surcharge Load. 


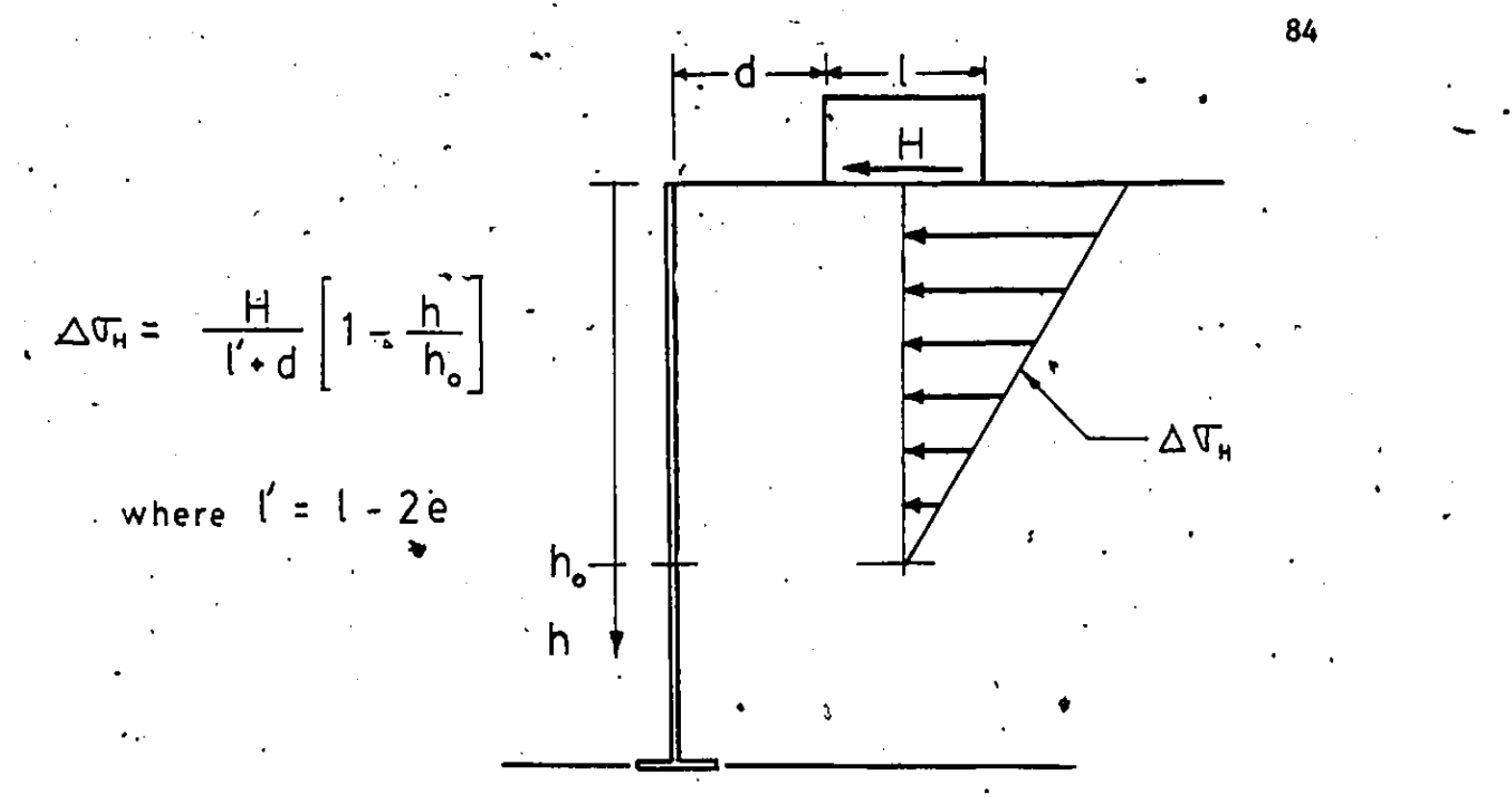

F1g. 2.11 French Proposal for Distribution of Horizontal Stresses within Soll Mass due to a Horizontal Surcharge Load.

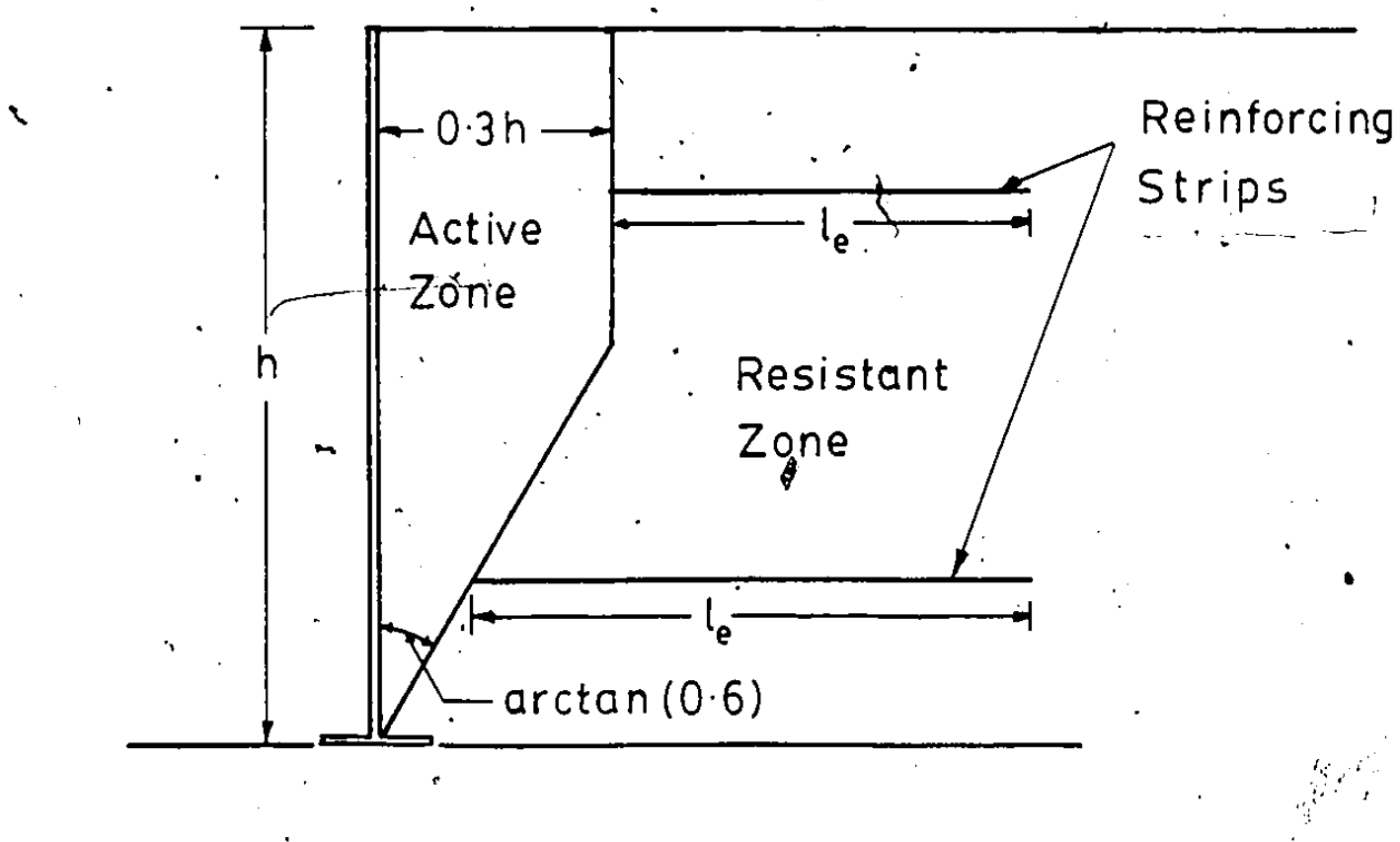

F1g. 2.12 Effective Length of the Reinforcement. 

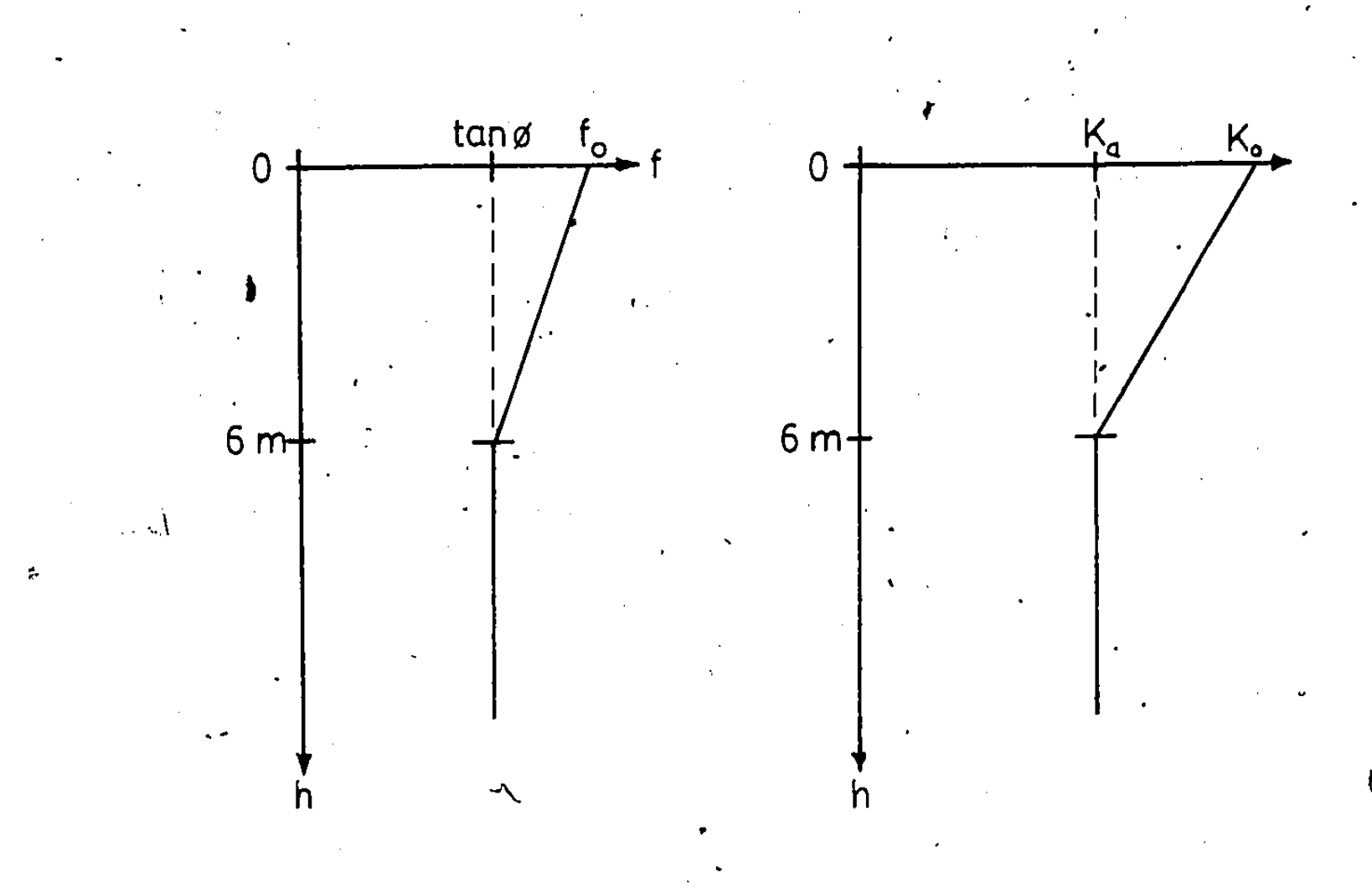

Flgs. 2.13 and 2.14 Design Values of Friction and Coeffictent of Lateral Earth Pressure as a Function of Depth.

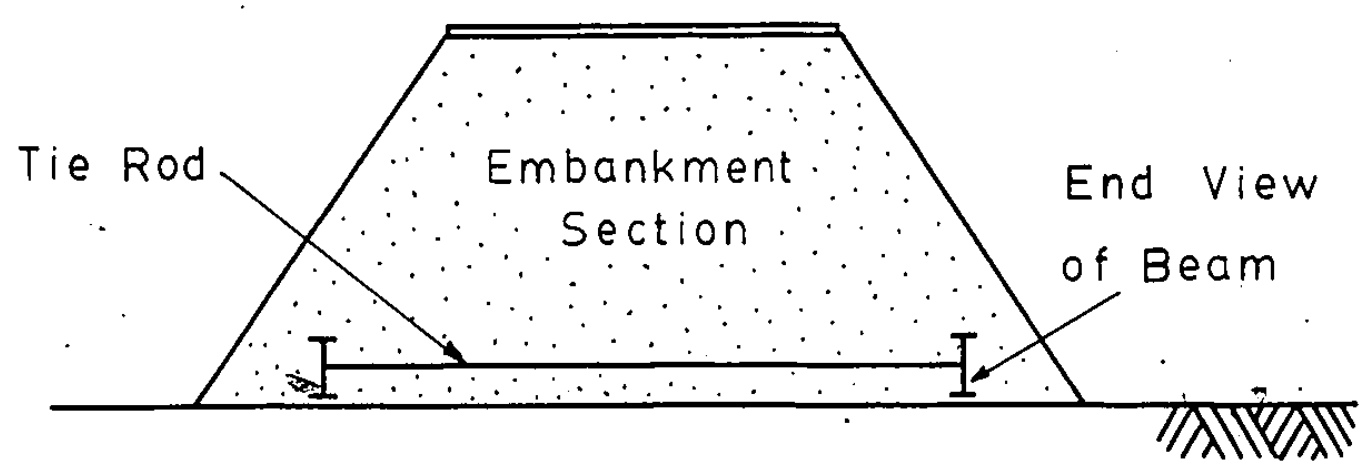

I

F1g. 2.15 The Use of Beams in Containing Excessive Lateral Stresses Developed at the Base of Embankments. 


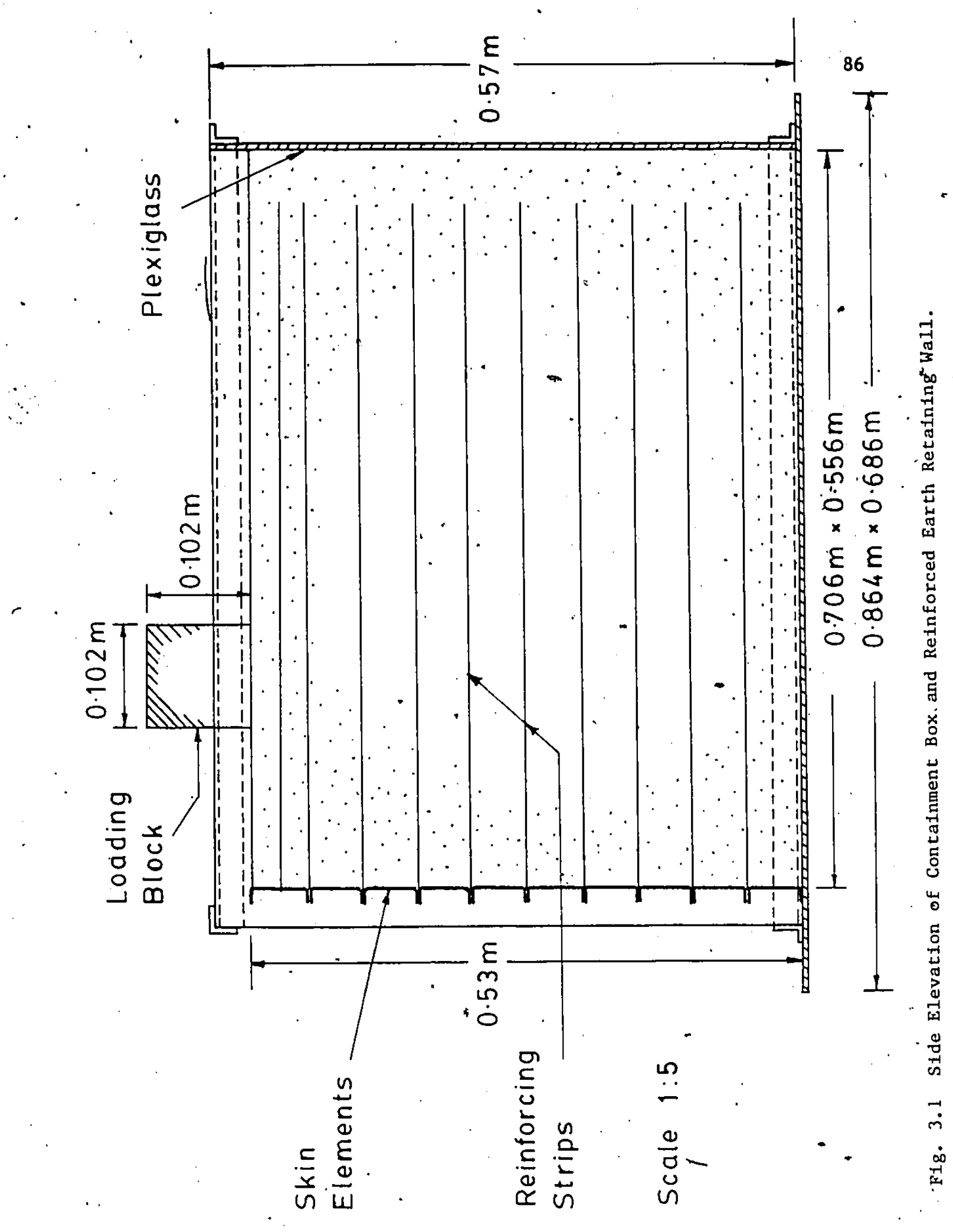




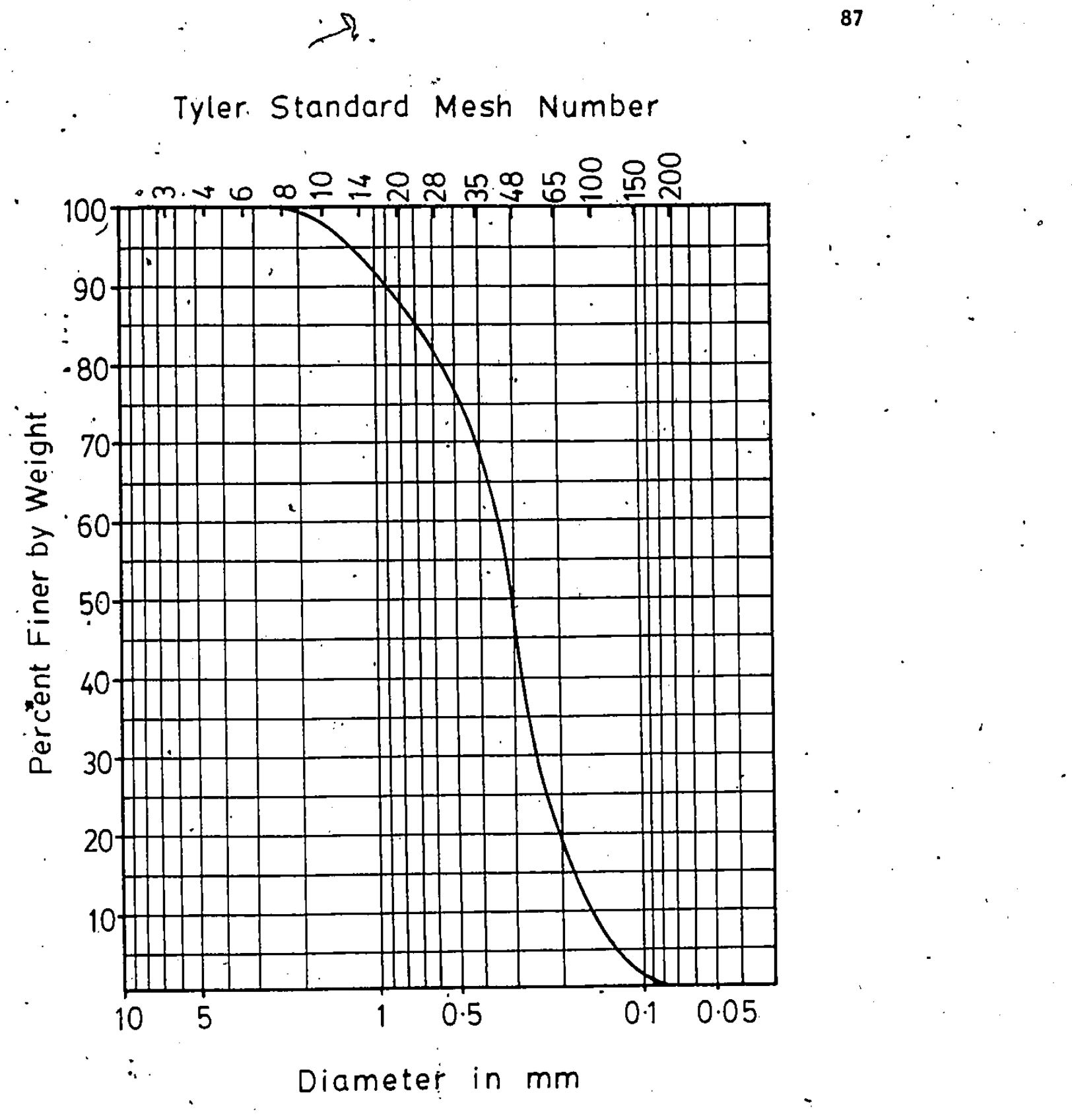

Fig. 3.2 Grain Size Distribution Curve for the Sand Backfill. 


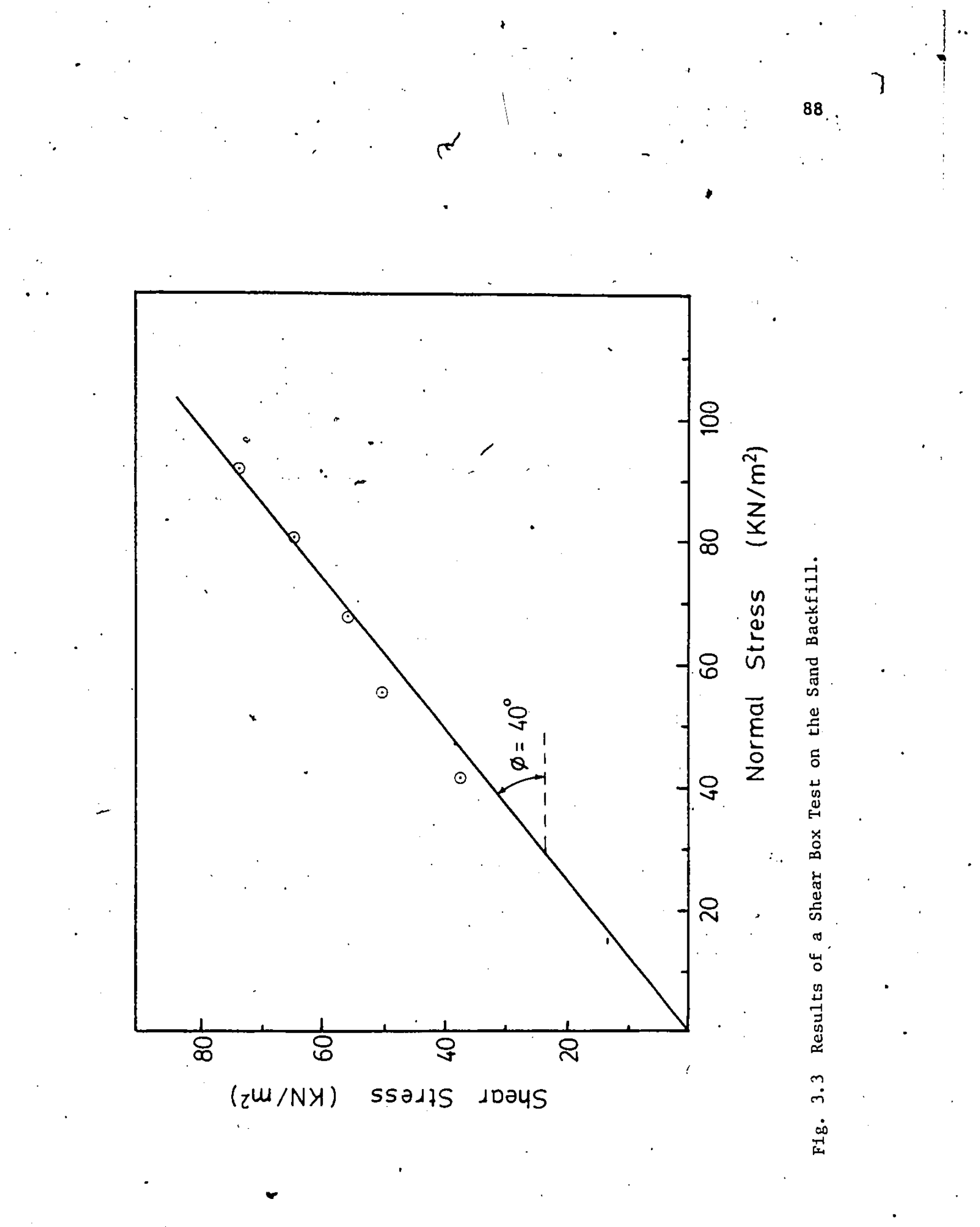




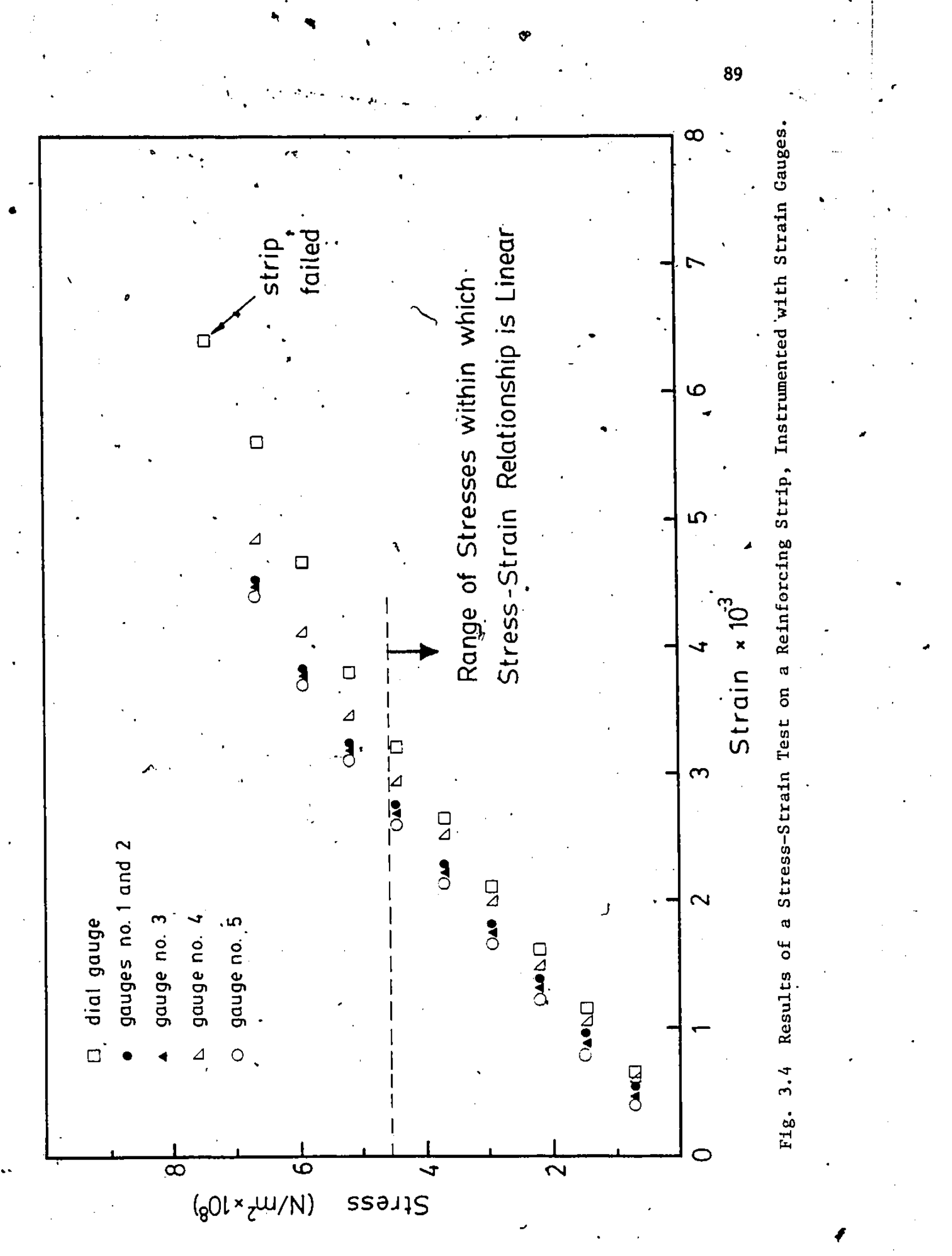




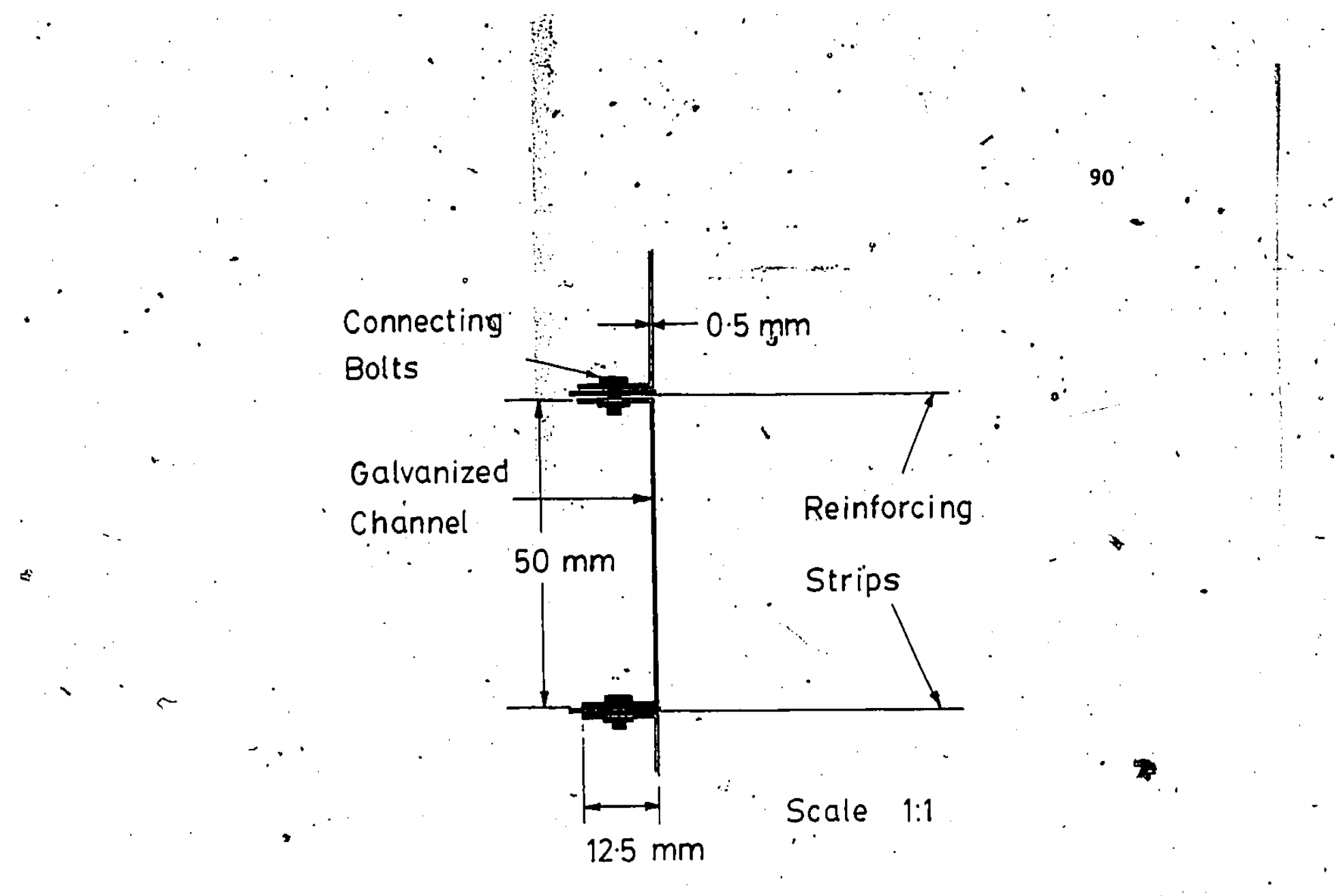

Fig. 3.5 Vertical Section Through the Skin Elements and Reinforcing Strips.

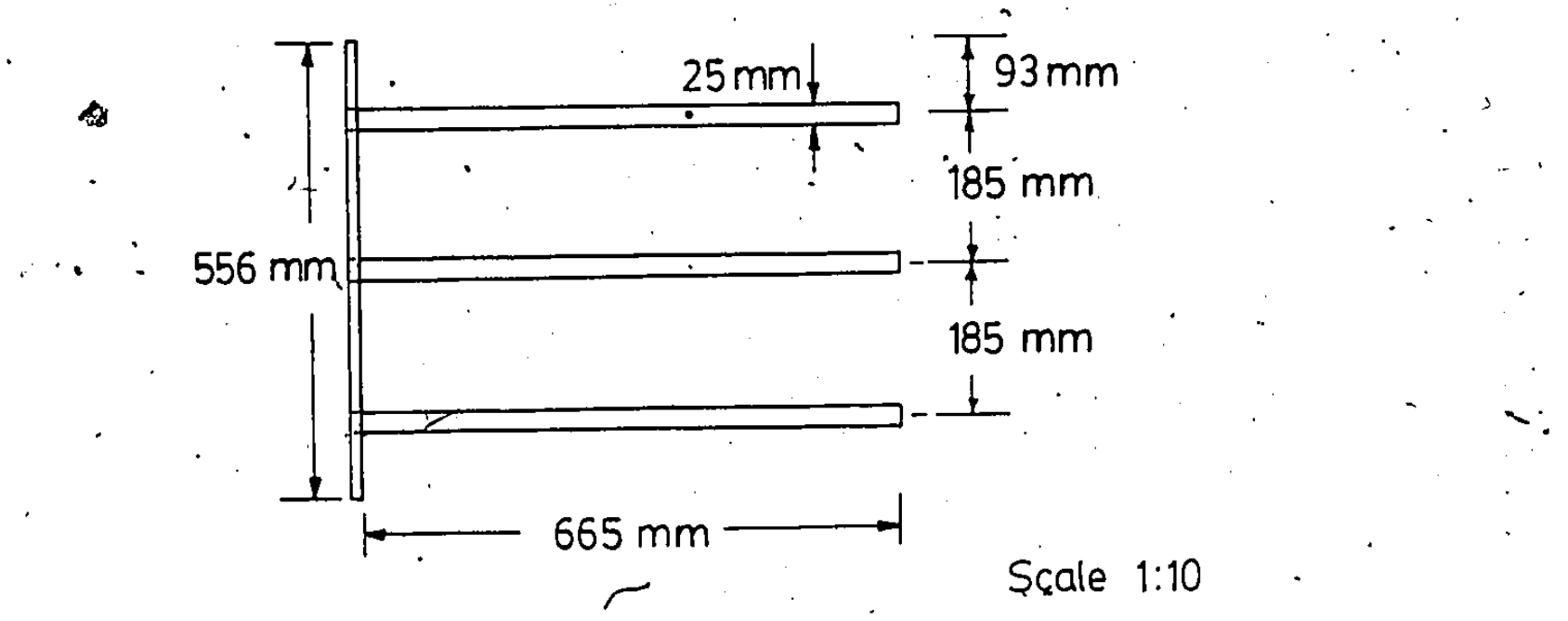

F1g. 3.6 View in Plan of the .S'cin Elements and Reinforcing Strips. 

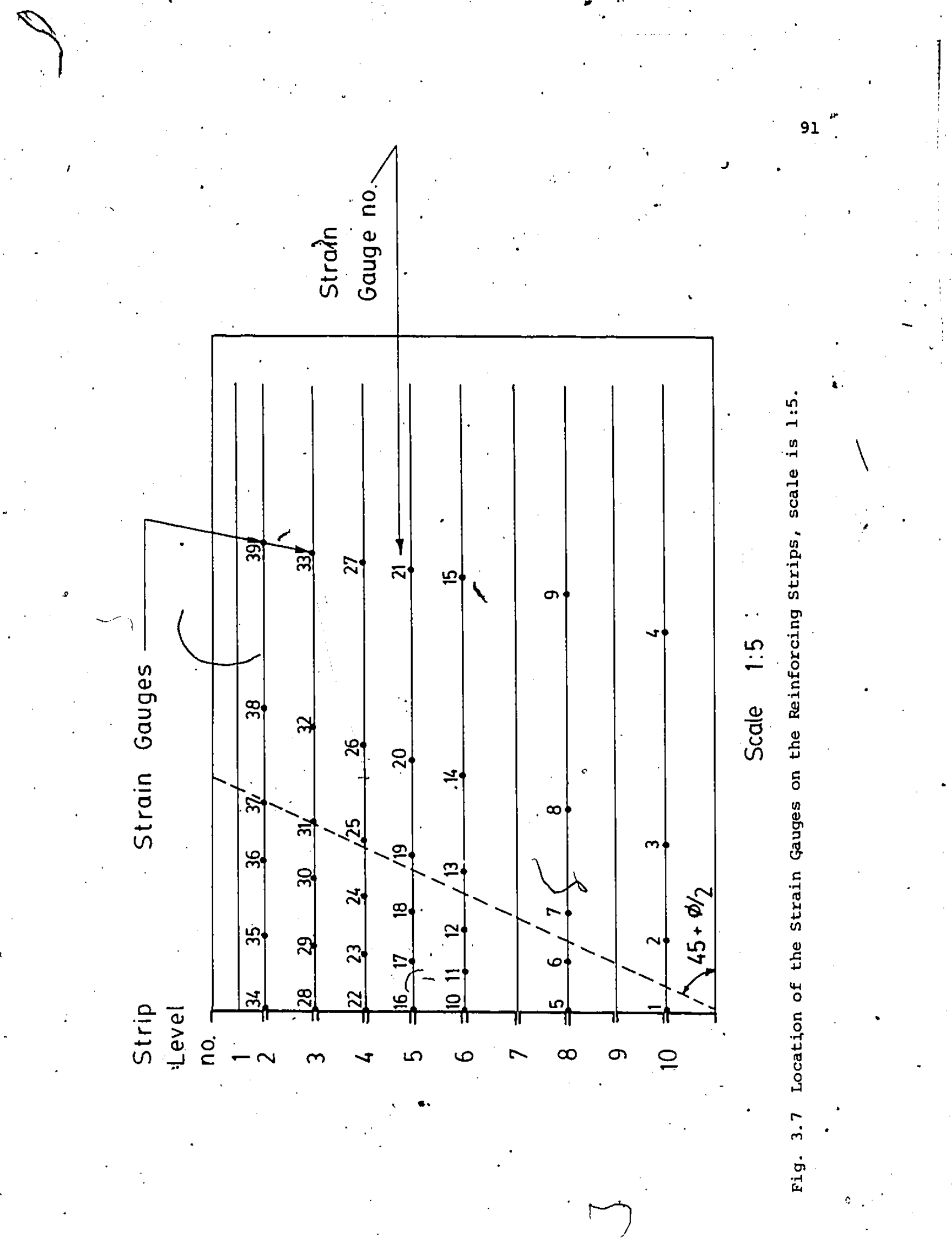



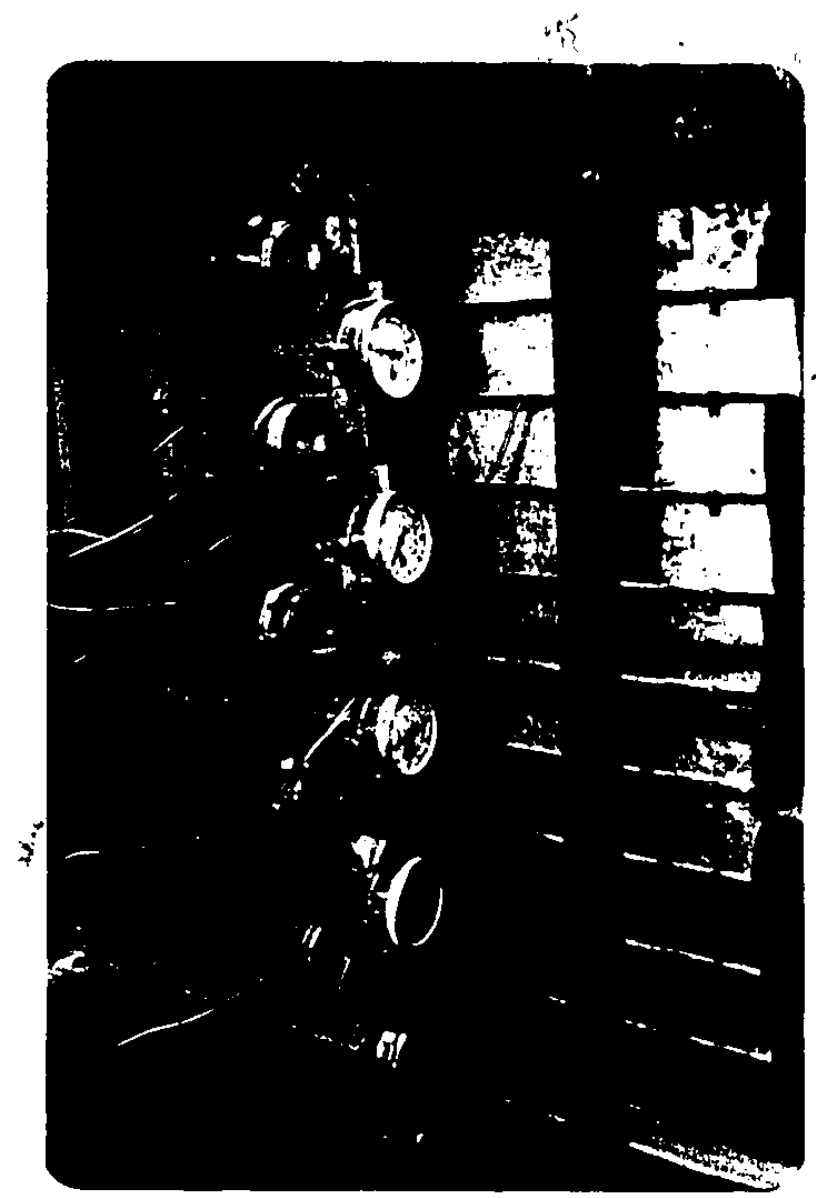

F1g. 3.9 Dial Gauges Used to Read Wall Deflection.

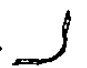




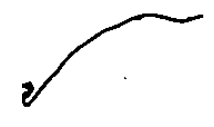

$$
\therefore
$$

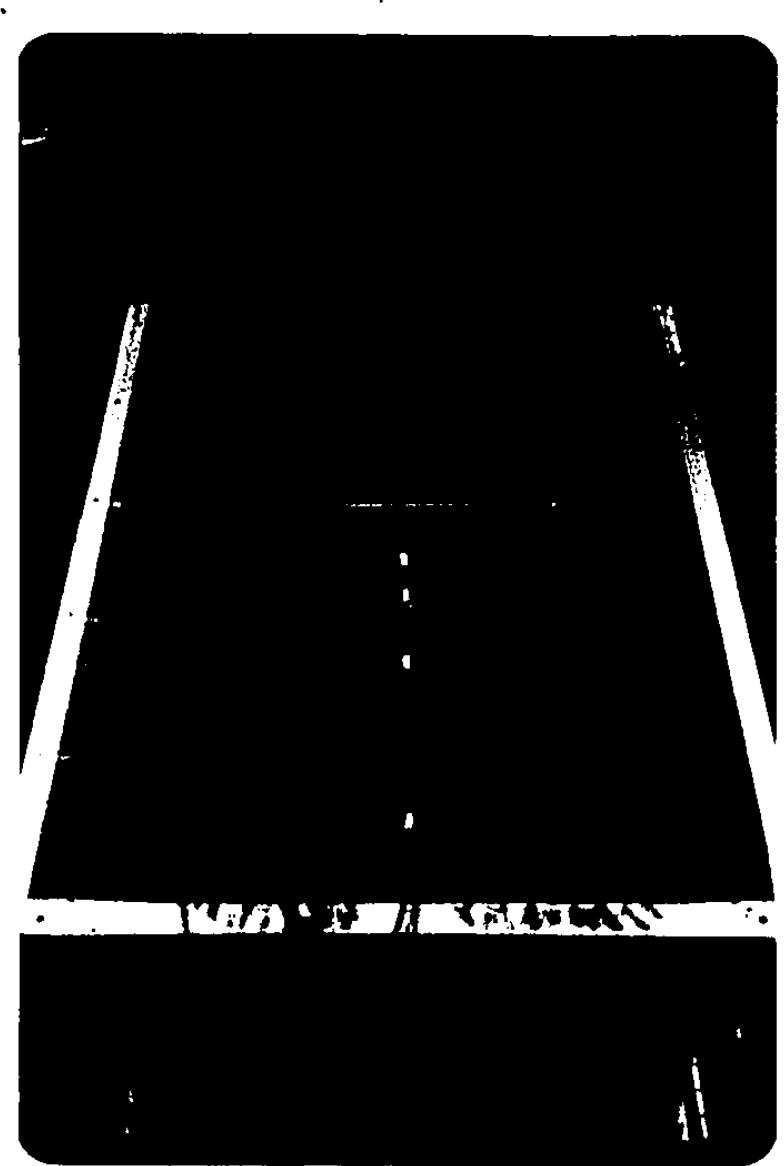

Fig. 3,10 Buflding up the Relnforced Earth System. 


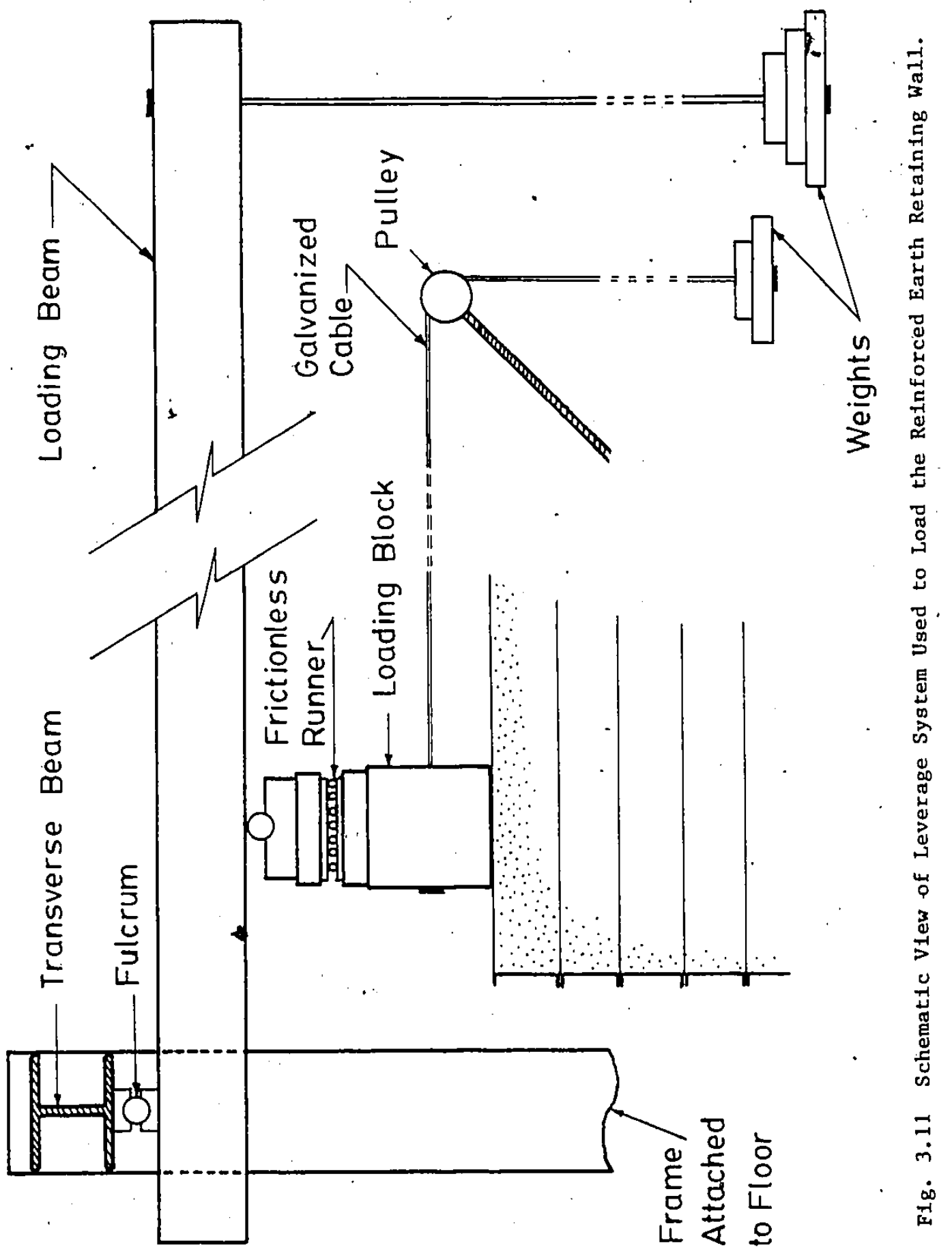




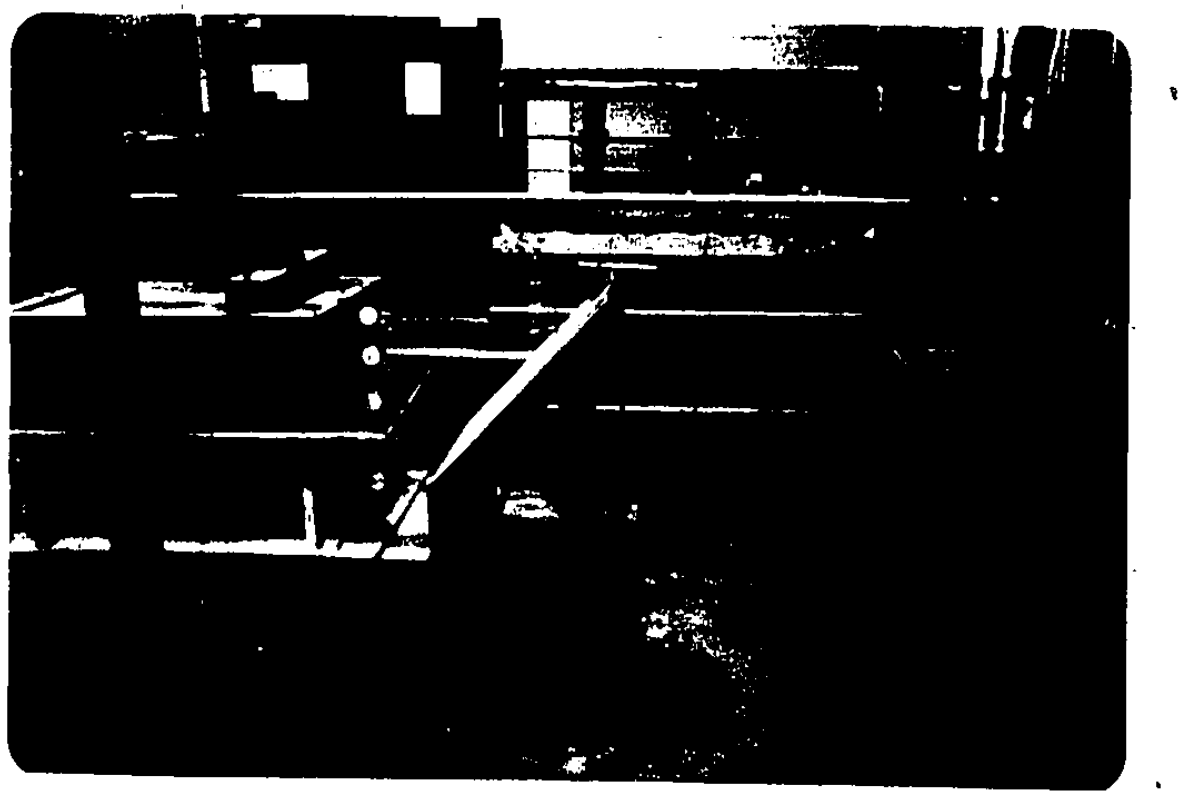

F1g. 3.12 Loading System : Horlzontal Component Directed Towards the Wall Face.

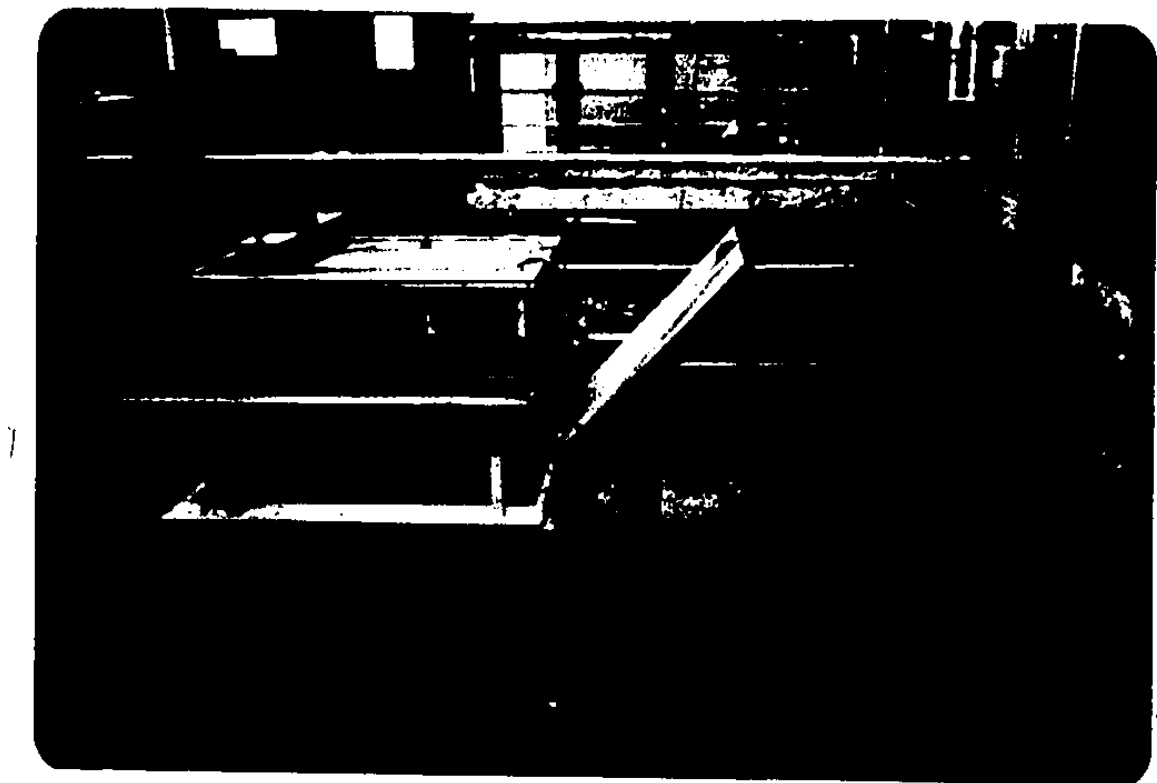

Fig. 3.13 Loading System : Horizontal Component Directed Away From the Wall Face. 


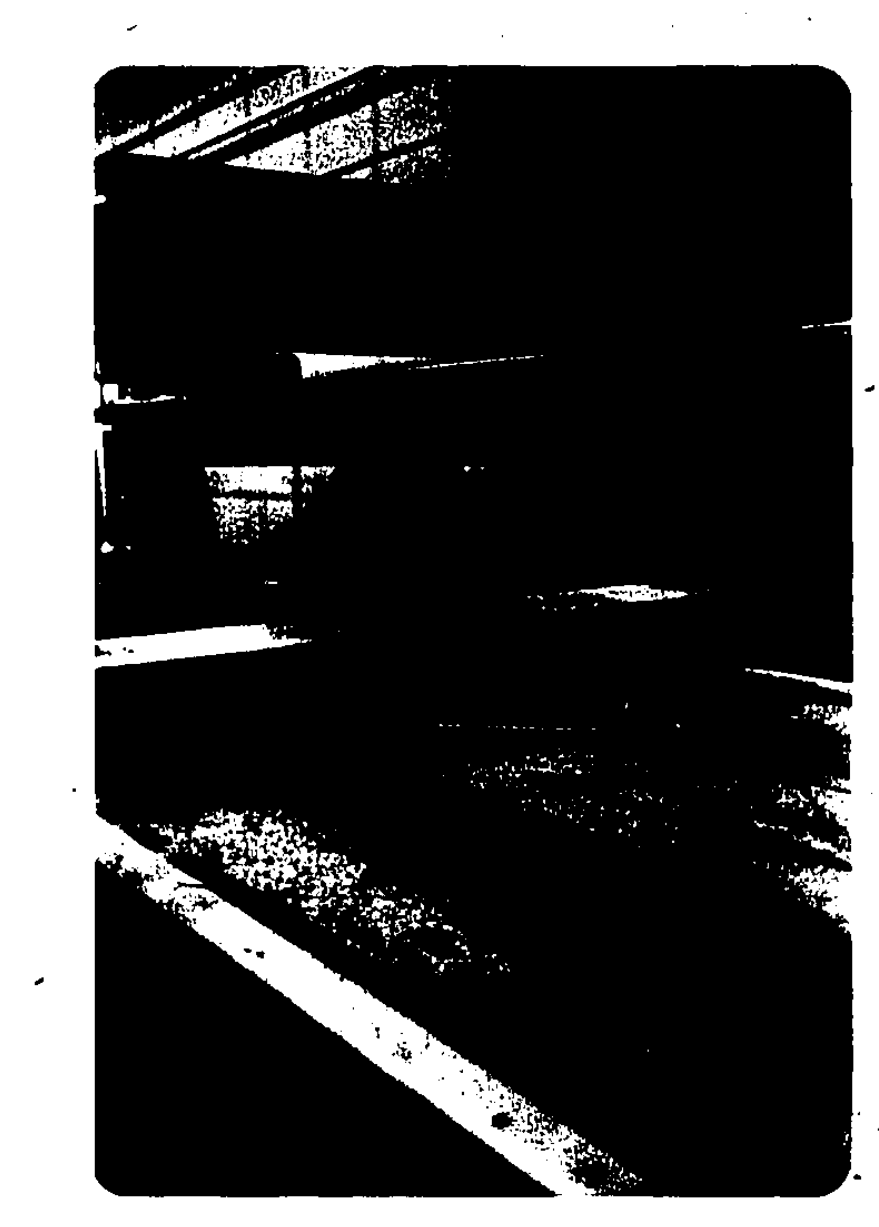

F1g. 3.14 Loading Block and Beam.

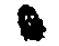




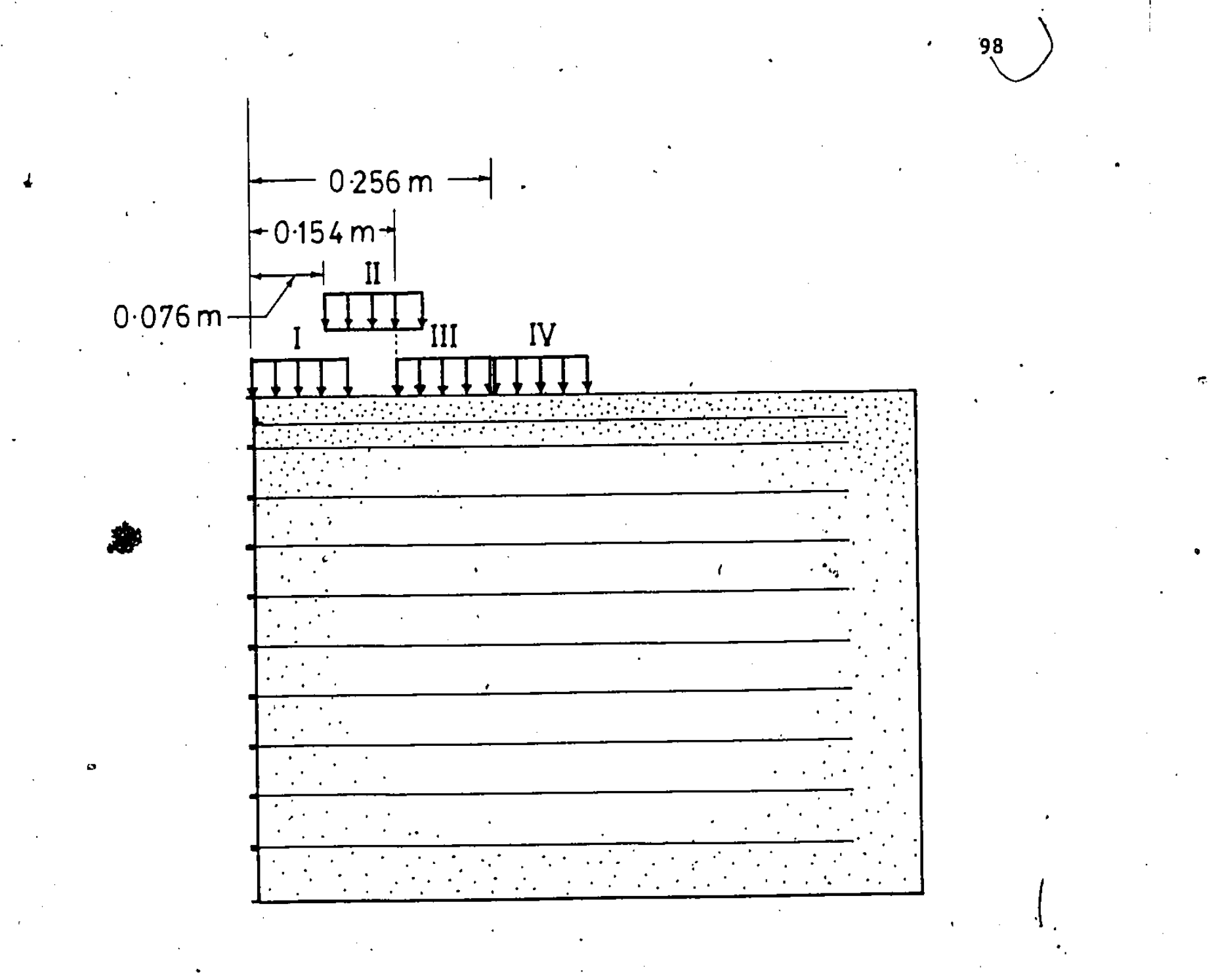

F1g. 3.15 Locations of the Surcharge Load. 


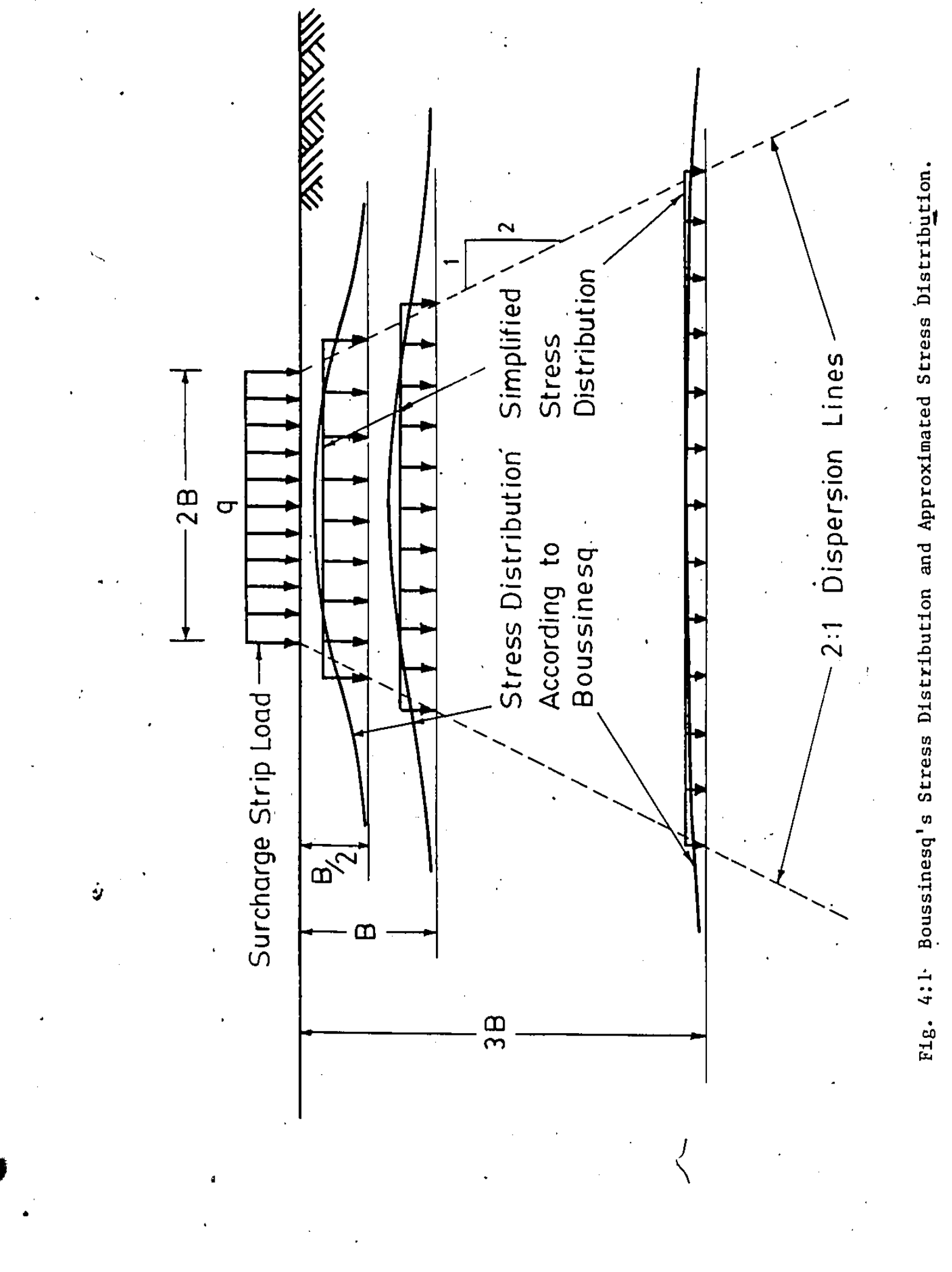

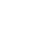




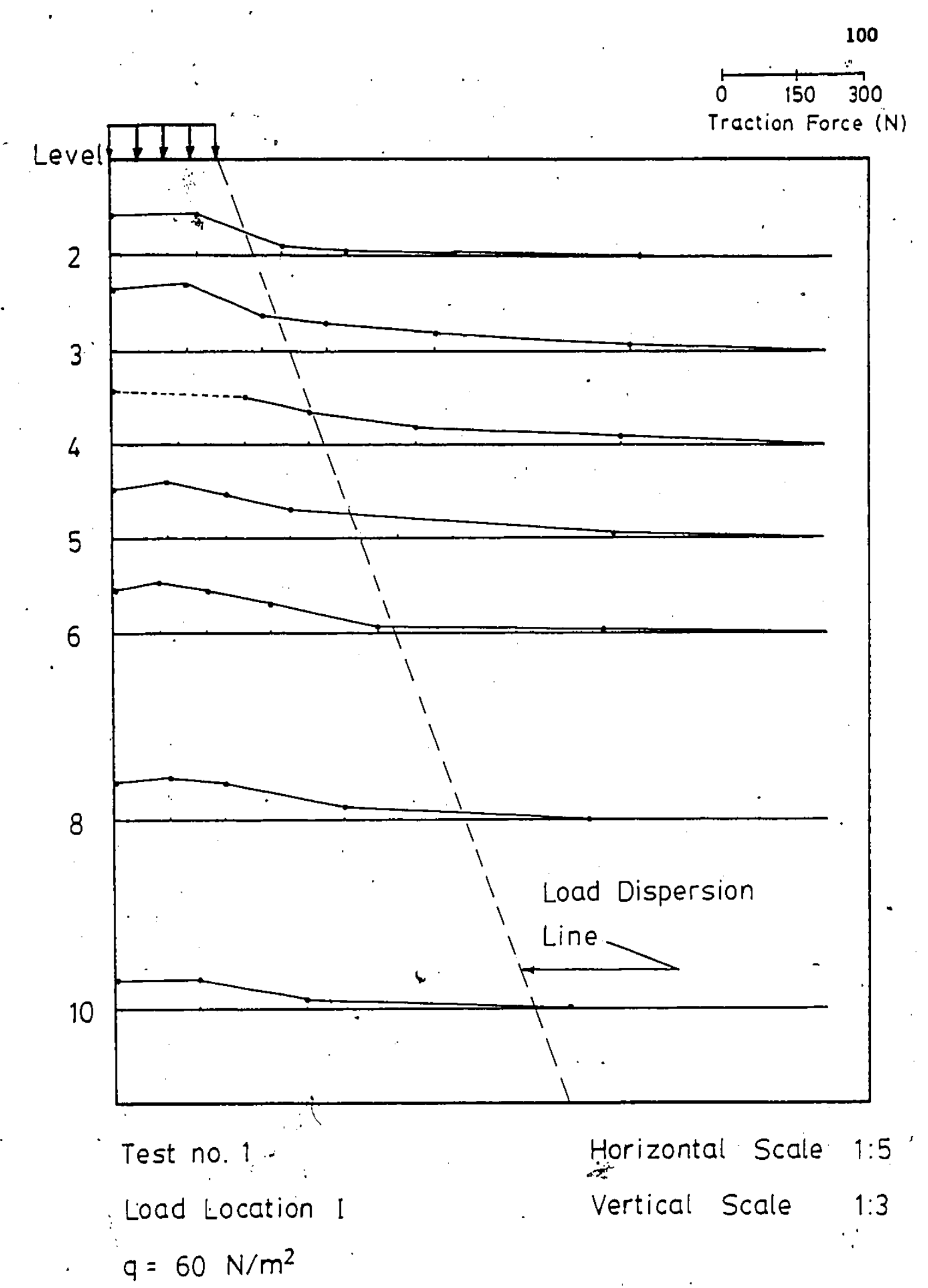

F1g. 4.2 Traction Force Distribution Along Strips, Under Vertical Load. 

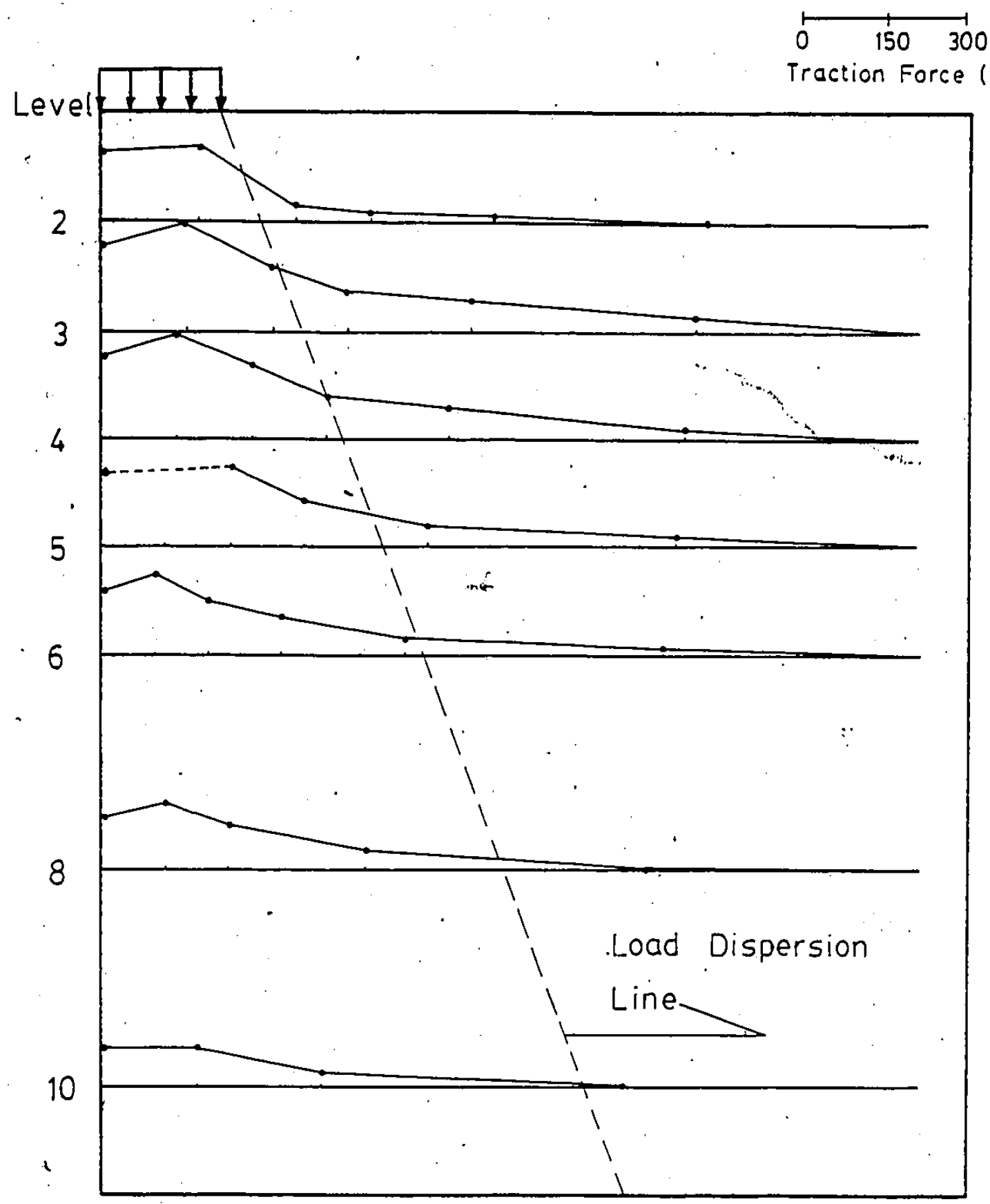

3

Test no. 3

Load Location I

$q=80 \mathrm{~N} / \mathrm{m}^{2}$
Horizontal Scale 1:5

Vertical Scale 1:3

F1g. 4.3. Traction Force Distribution Along Strips, Under Vertical Load. 


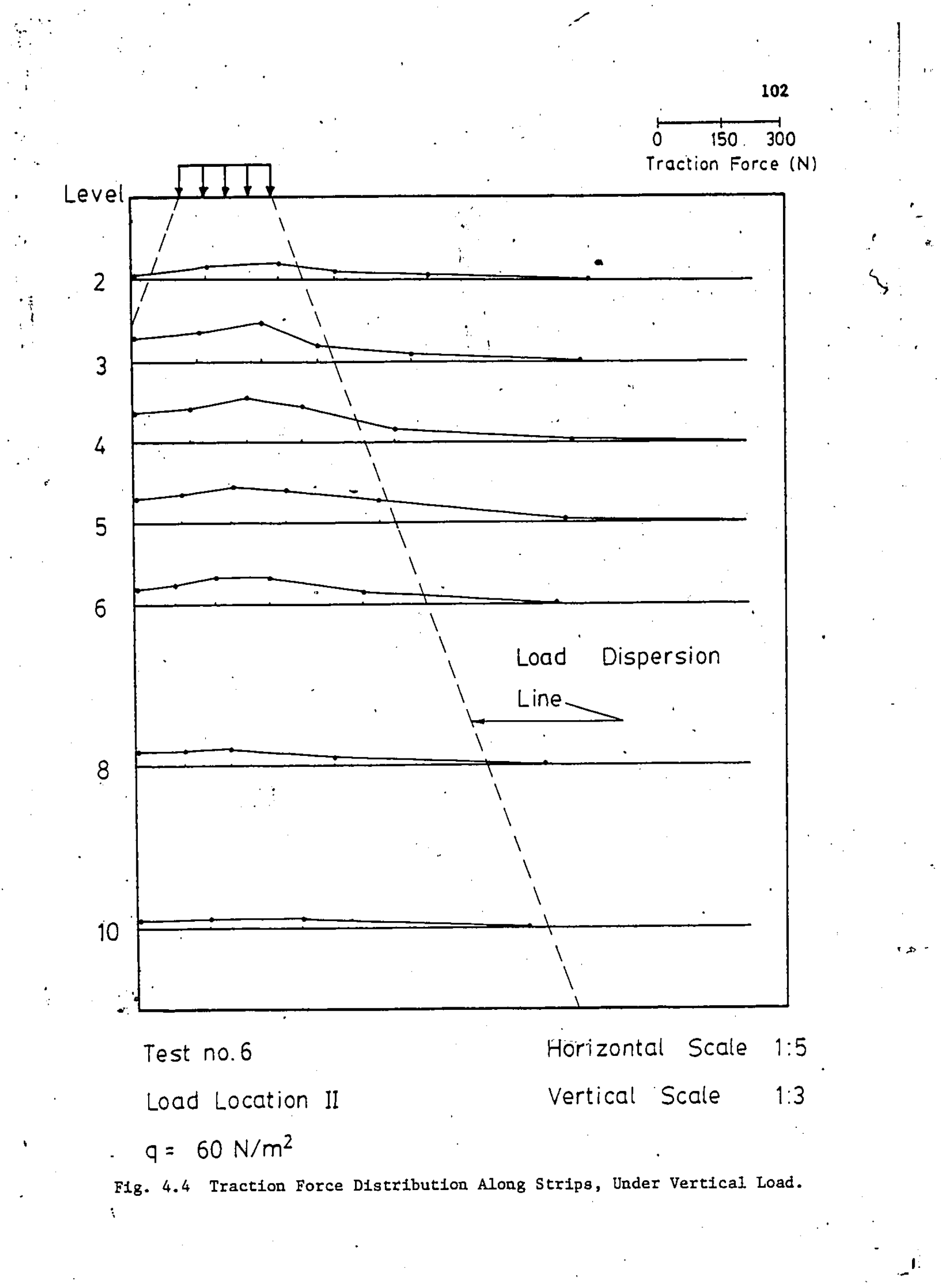




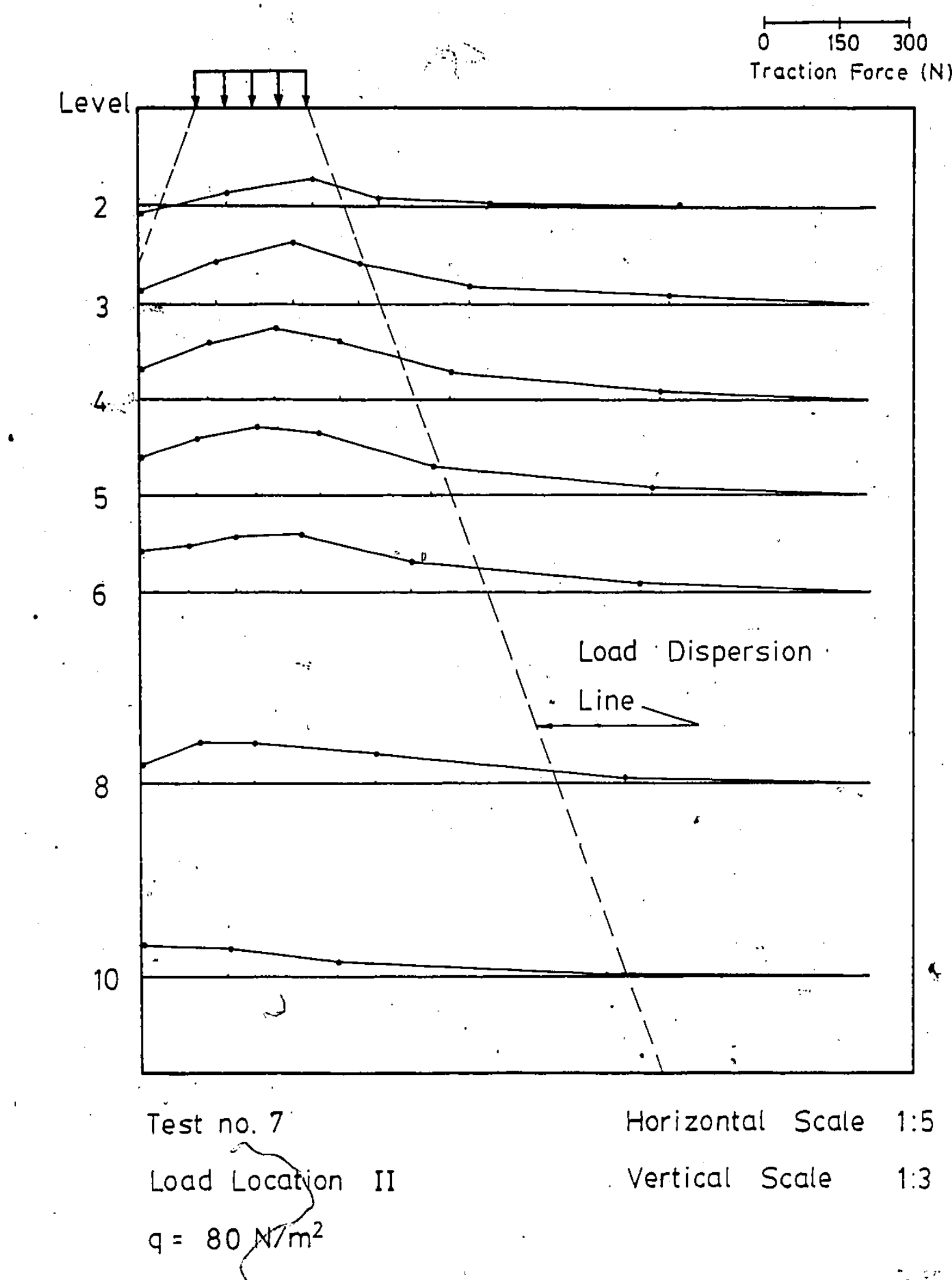

Fig. 4.5 Trdętion Force Distribution Along Strips, Under Vertical Load." 


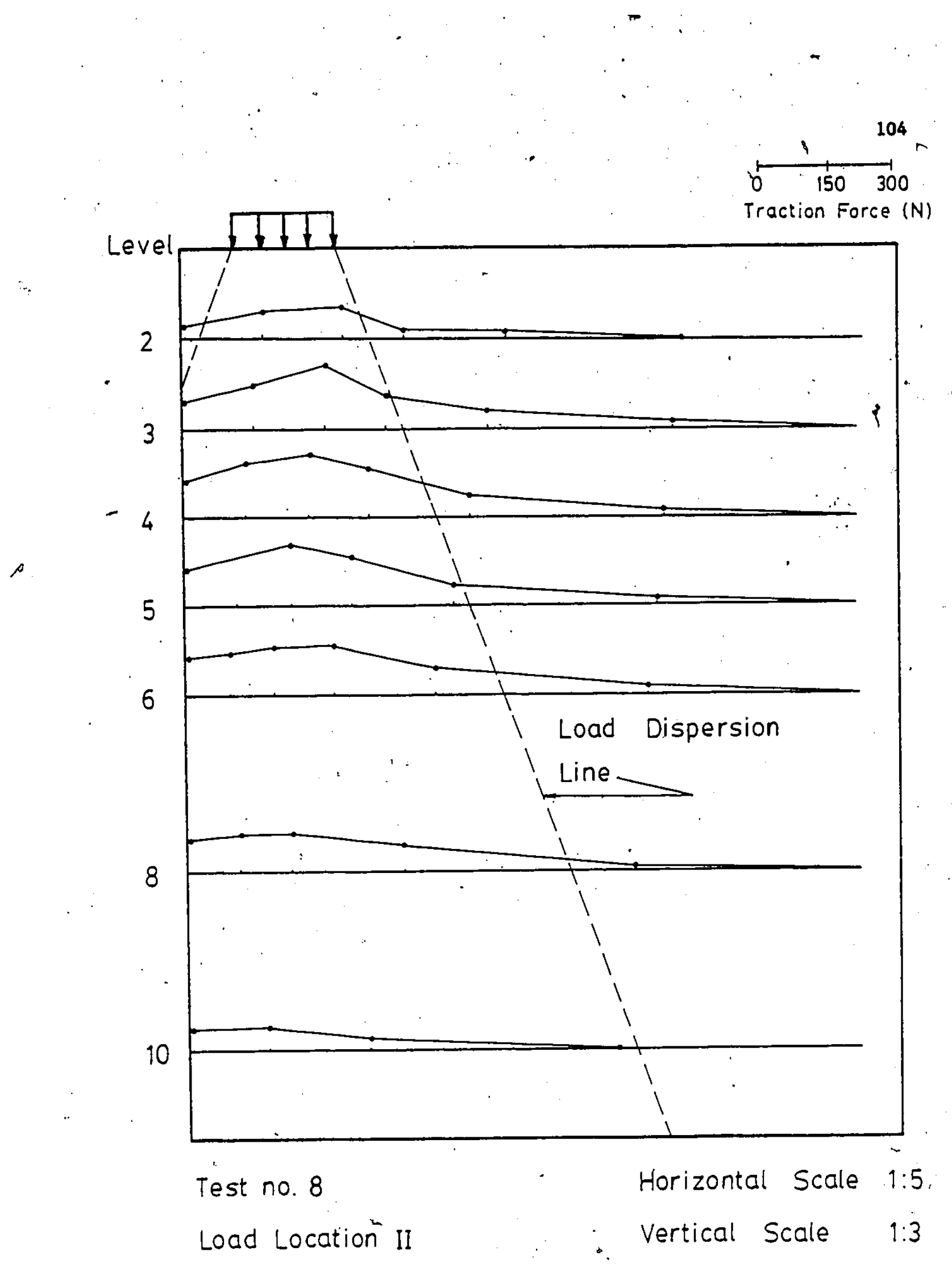

, $q=80 \mathrm{~N} / \mathrm{m}^{2}$

F1g. 4.6 Traction Force Distribution Along Strips, Under Vertical Load. 

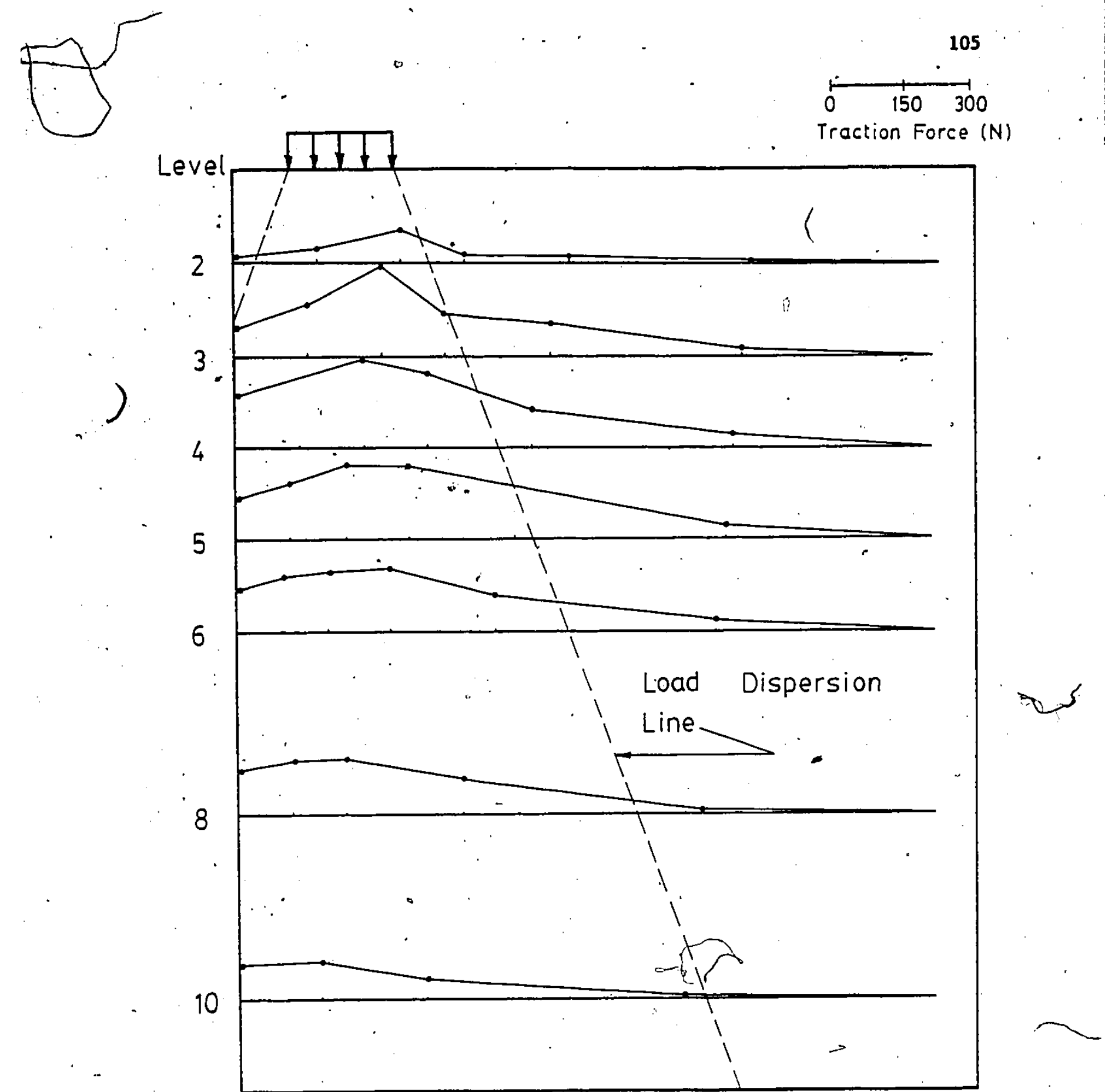

. Test no. 9

Horizontal Scale 1:5

Load Location II Vertical Scale $1: 3$

$q=100 \mathrm{~N} / \mathrm{m}^{2}$

F1g. 4.7 Traction Force Distribution Along Strips, Under Vertical Load. 


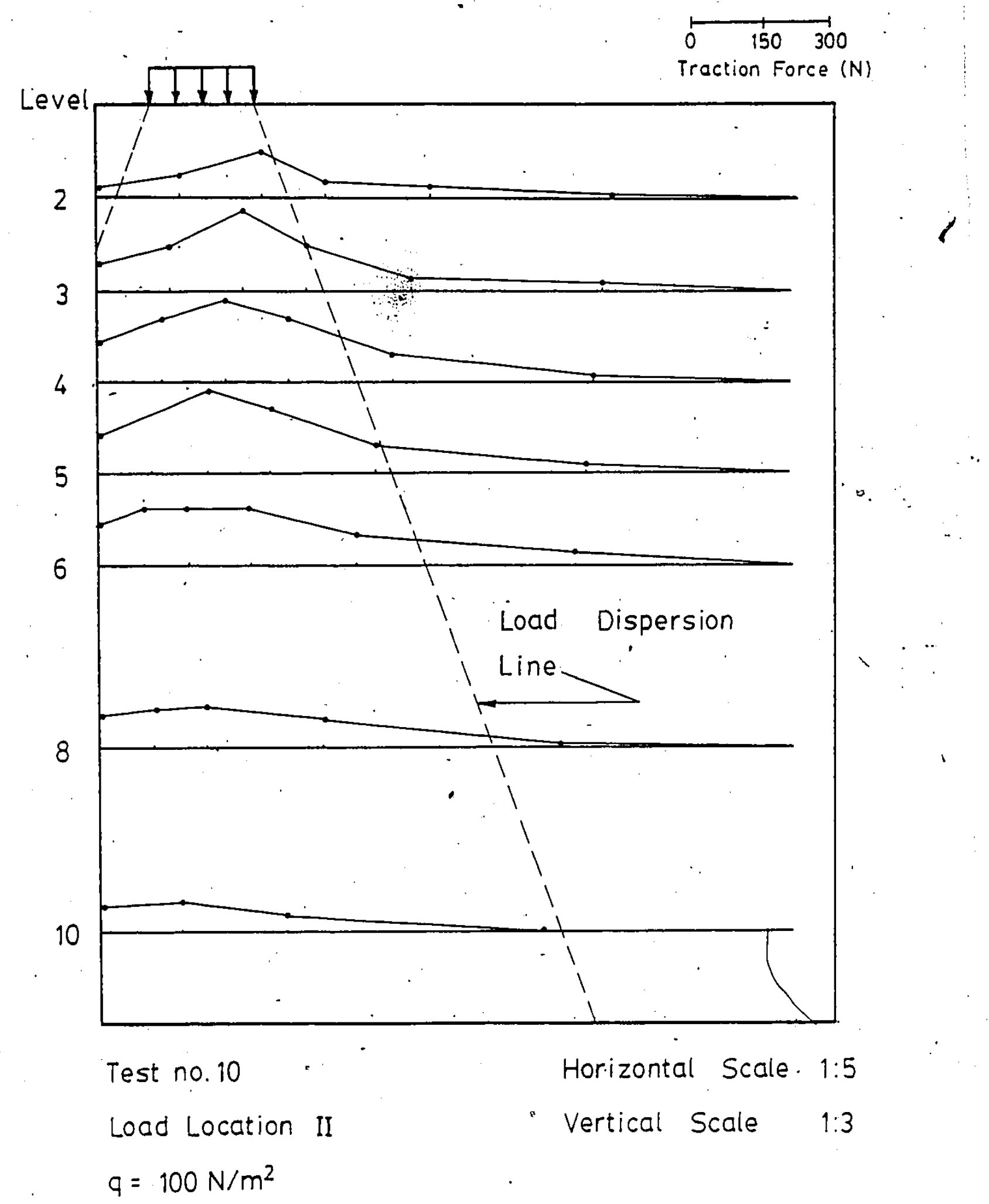

Fig. 4.8 Traction Force Distribution Along Strips, Under Vertical load. 


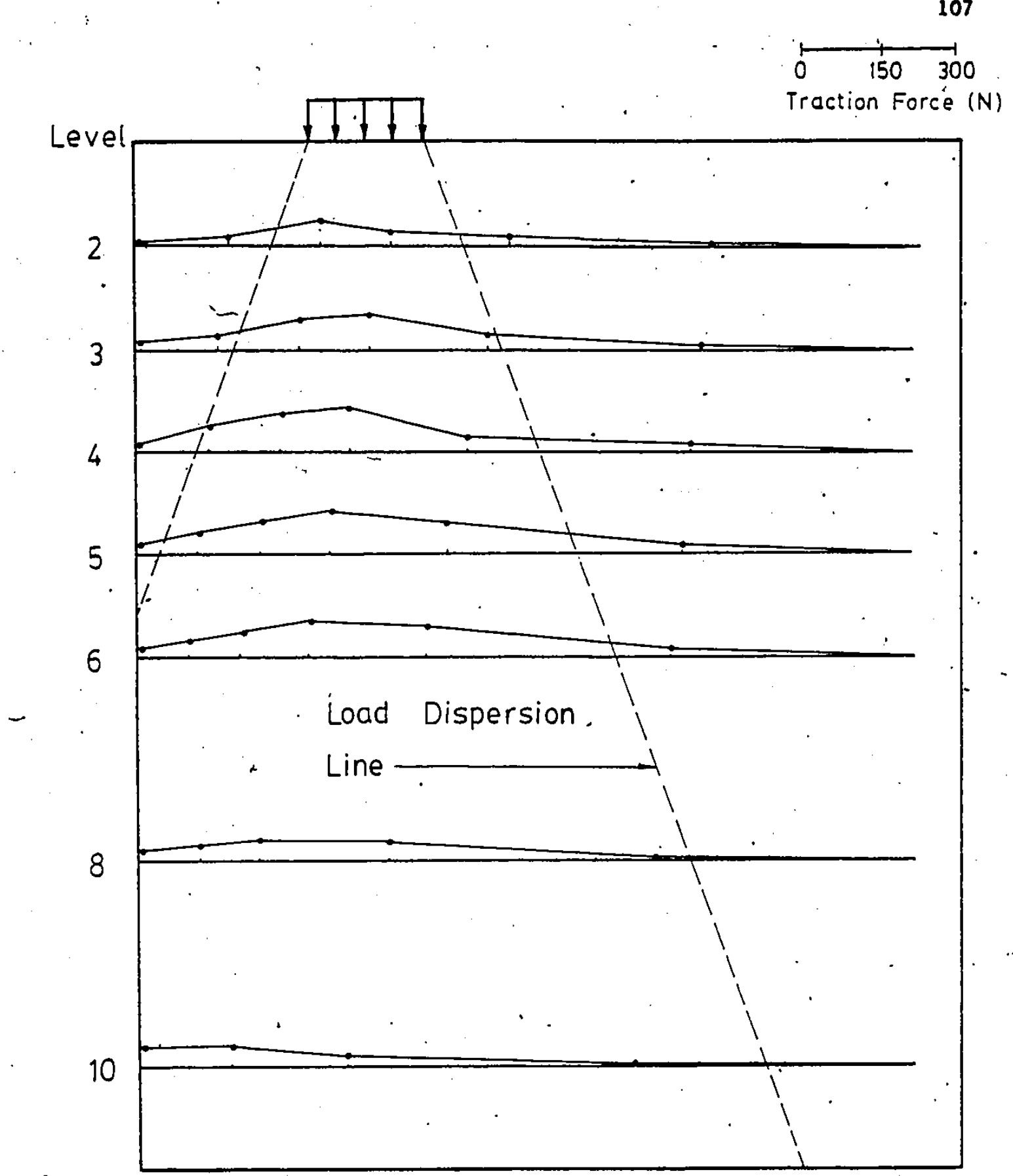

Test no. 12

Horizontal Scale 1:5

Load Location III

Vertical Scale $\quad 1: 3$

$q=60 \mathrm{~N} / \mathrm{m}^{2}$

Fig. 4.9 Traction Force Distribution Along Strips, Under Vertical Load. 


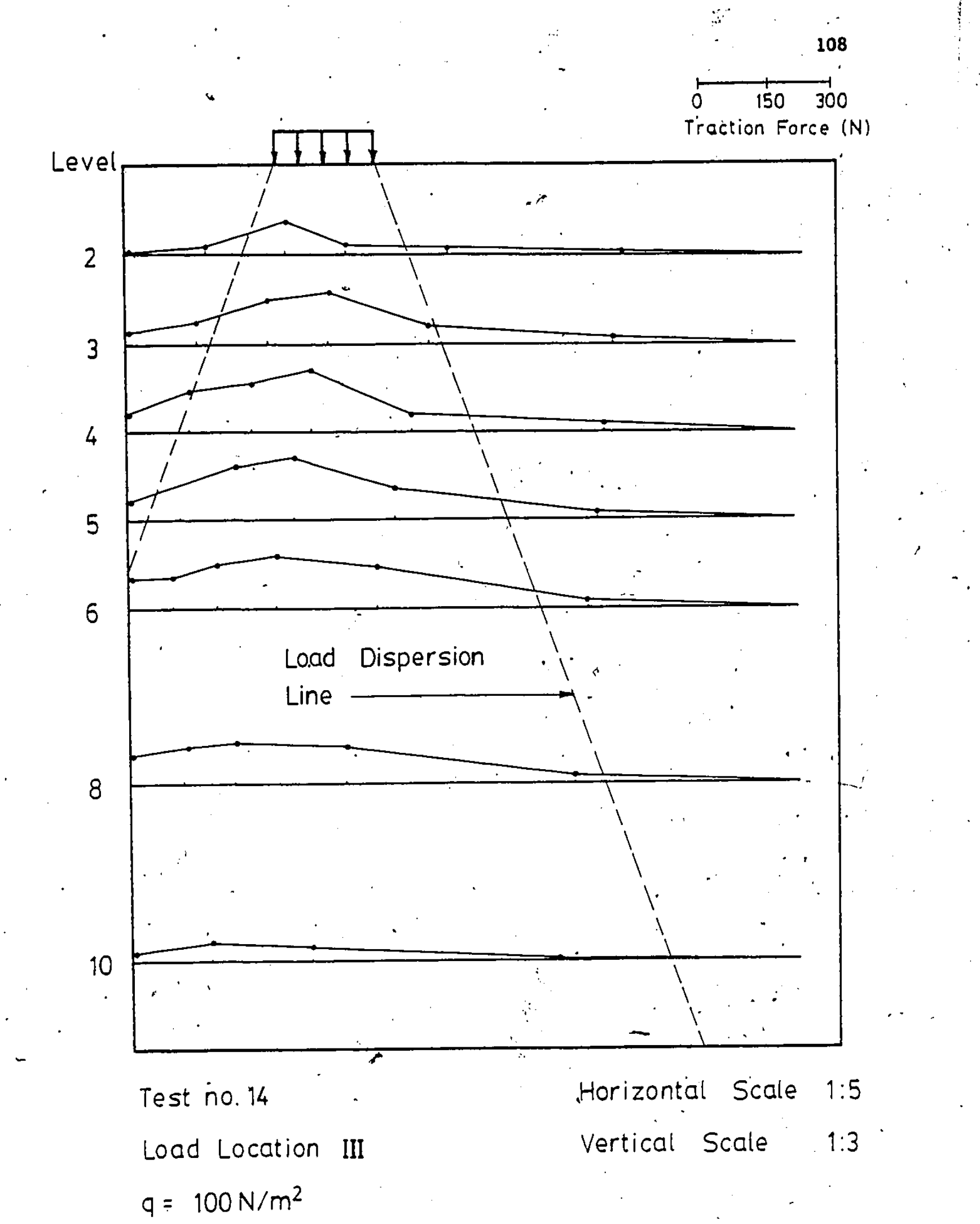

F18. 4.10 Traction Force Distribution Along Strips, Under Verticalload. 


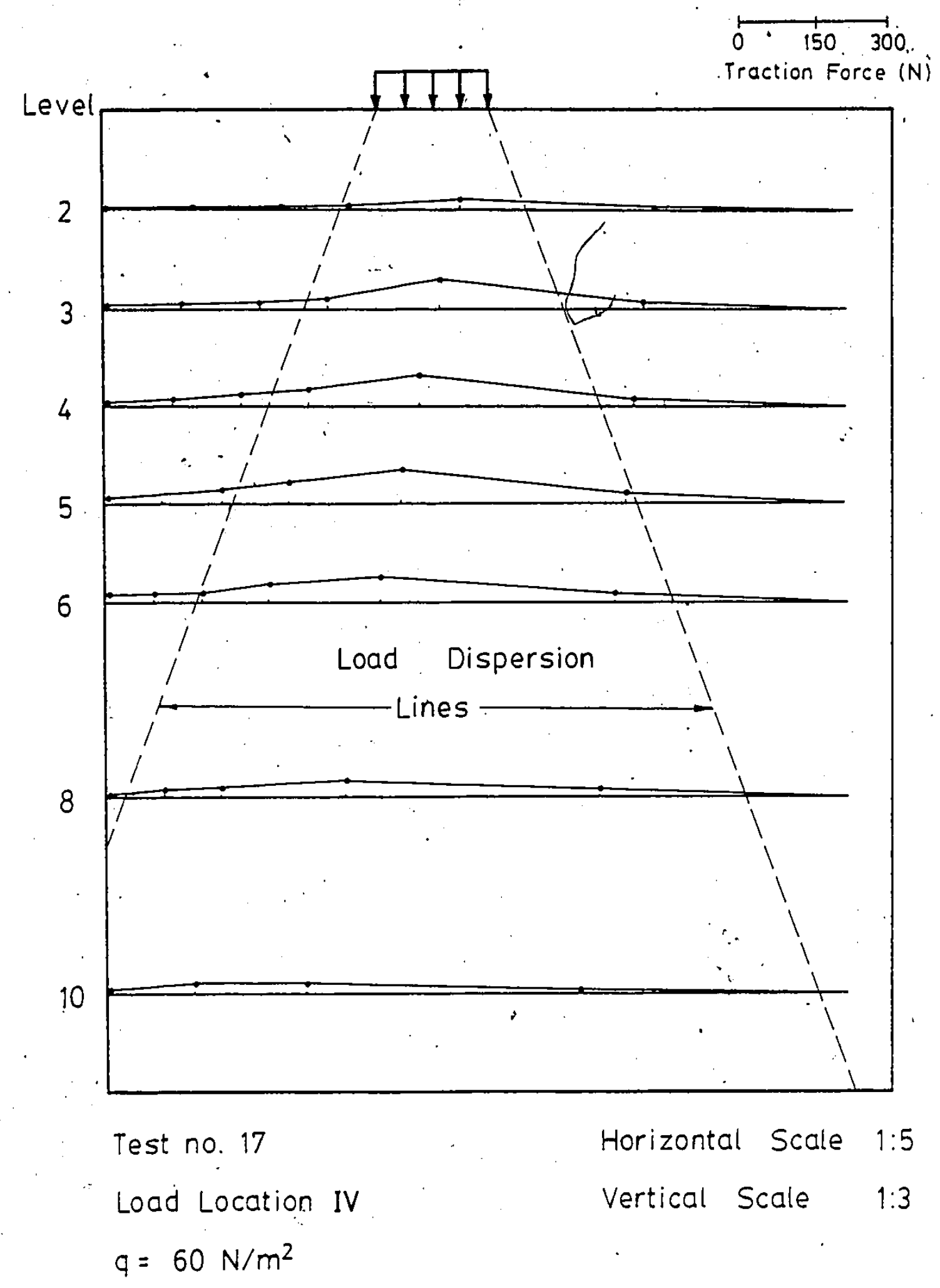

, Fig. 4.11 Traction Force Distrtbution Along Strips, Under Vertical Load. . 


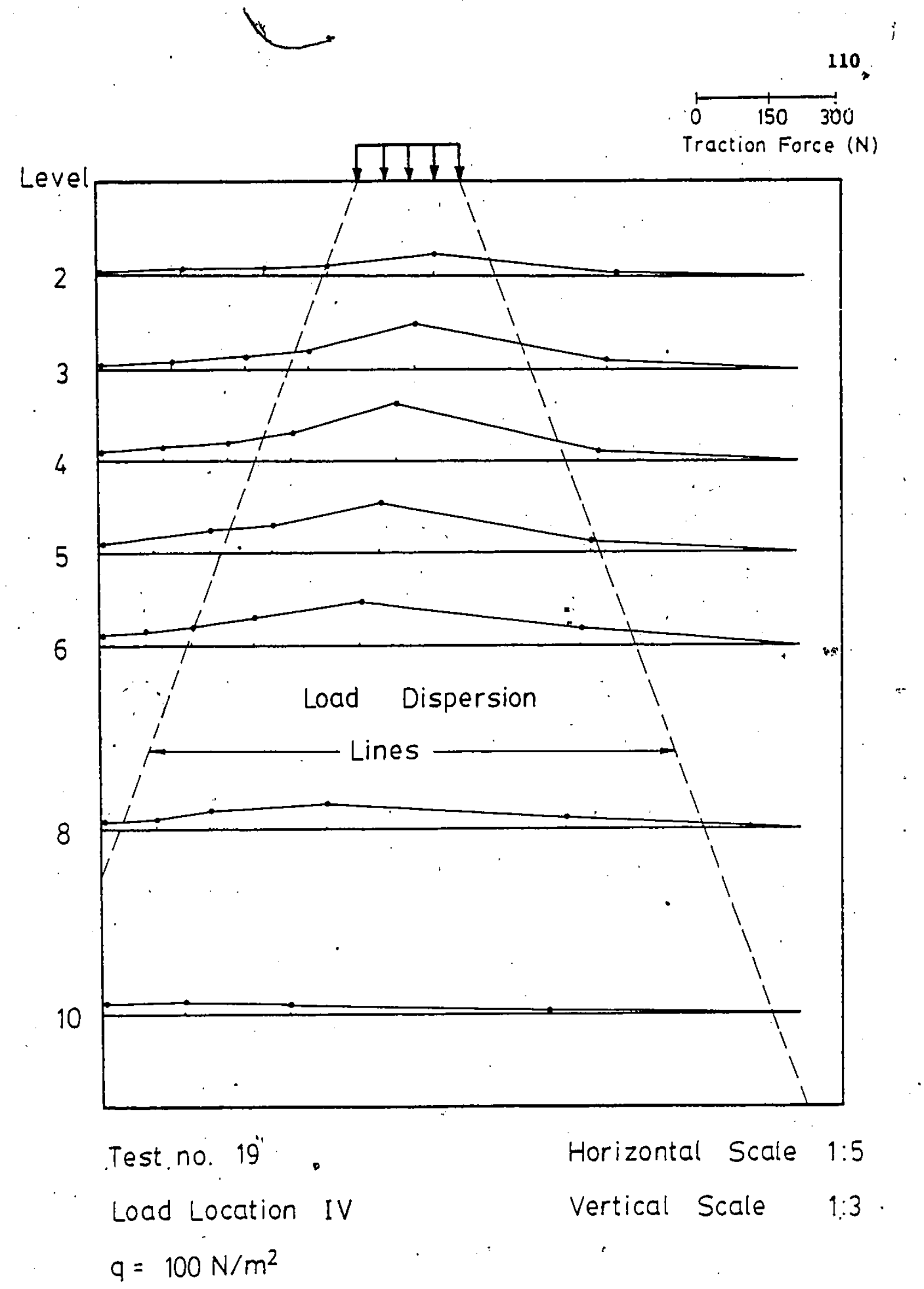

F1g." 4.12 Traction Force Distribution Along Strips, "Under Verticai Load. 


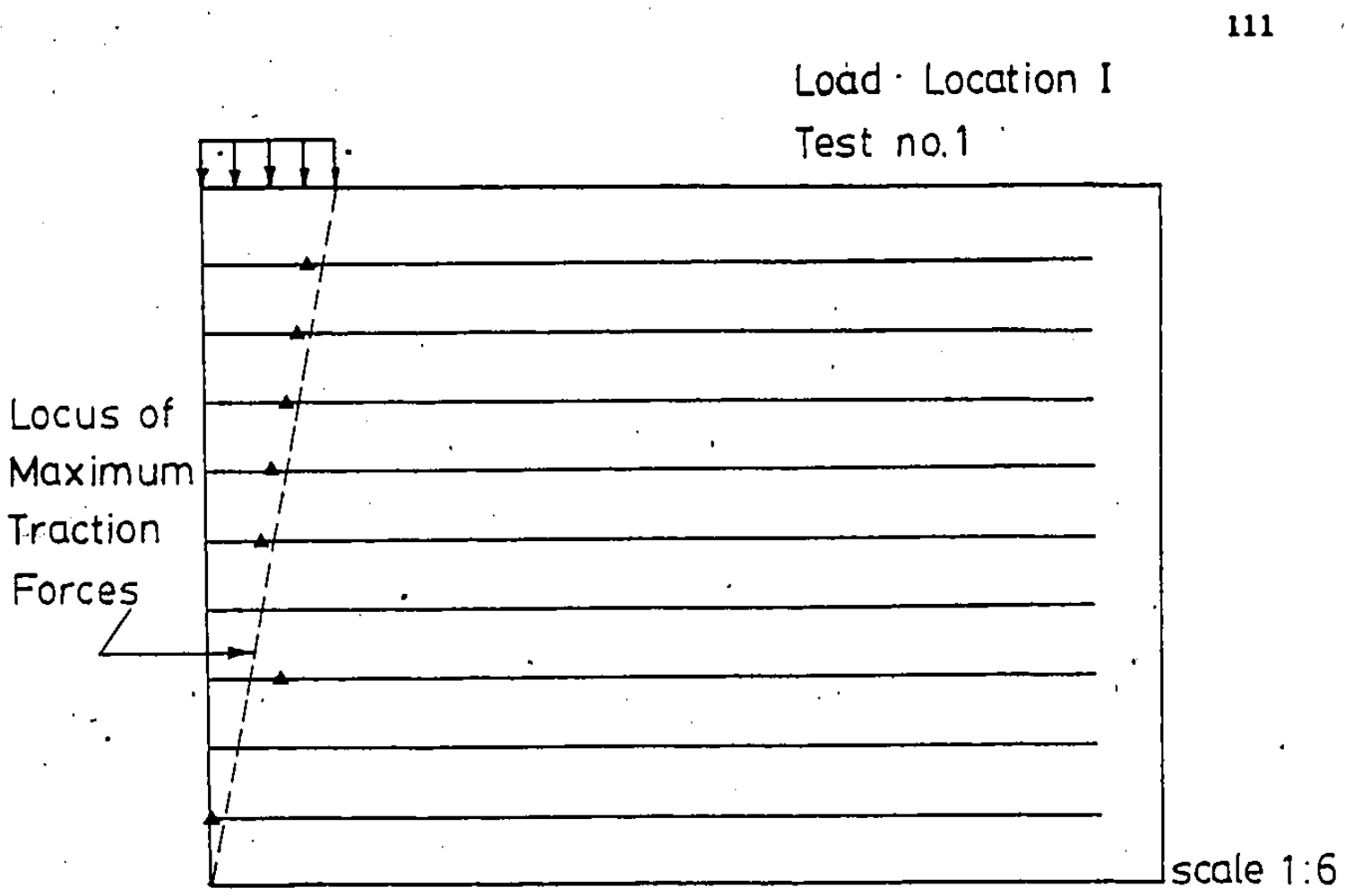

E1g. 4.13 Location of Potent1al Fallure Plane.

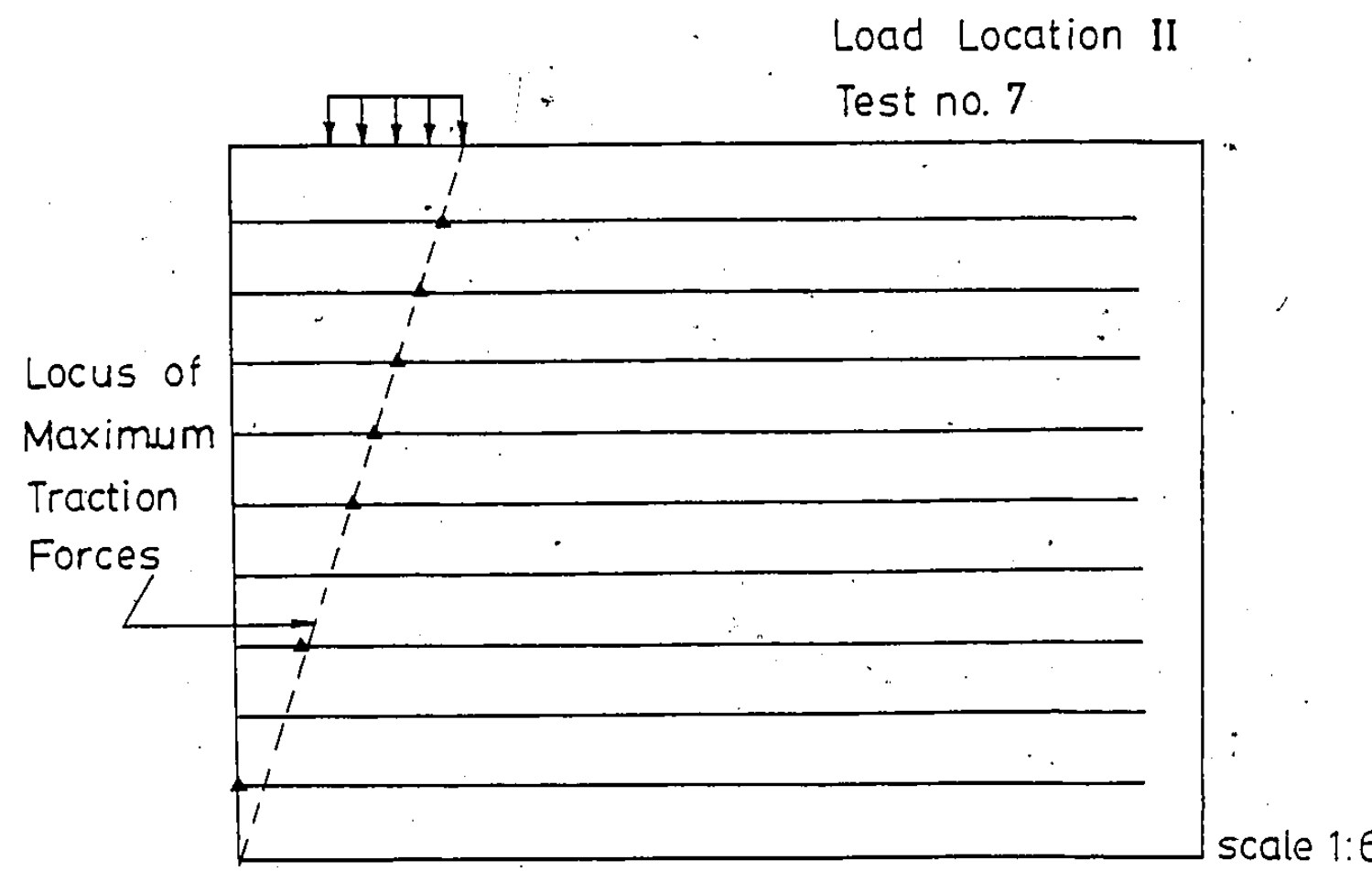

F1g. 4.14 Location of Potential Failure Plane. 


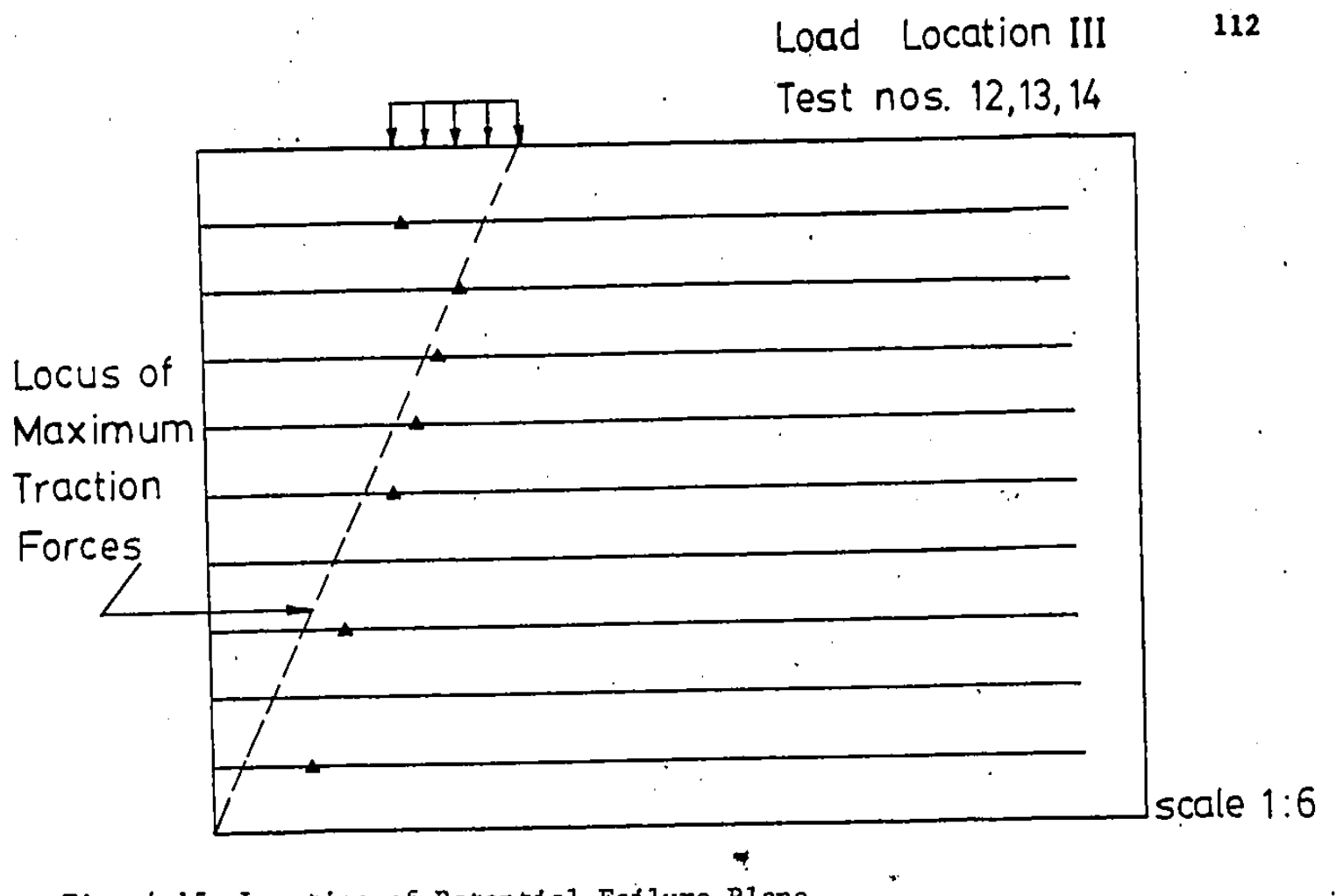

Fig. 4.15 Location of Potential Failure Plane.

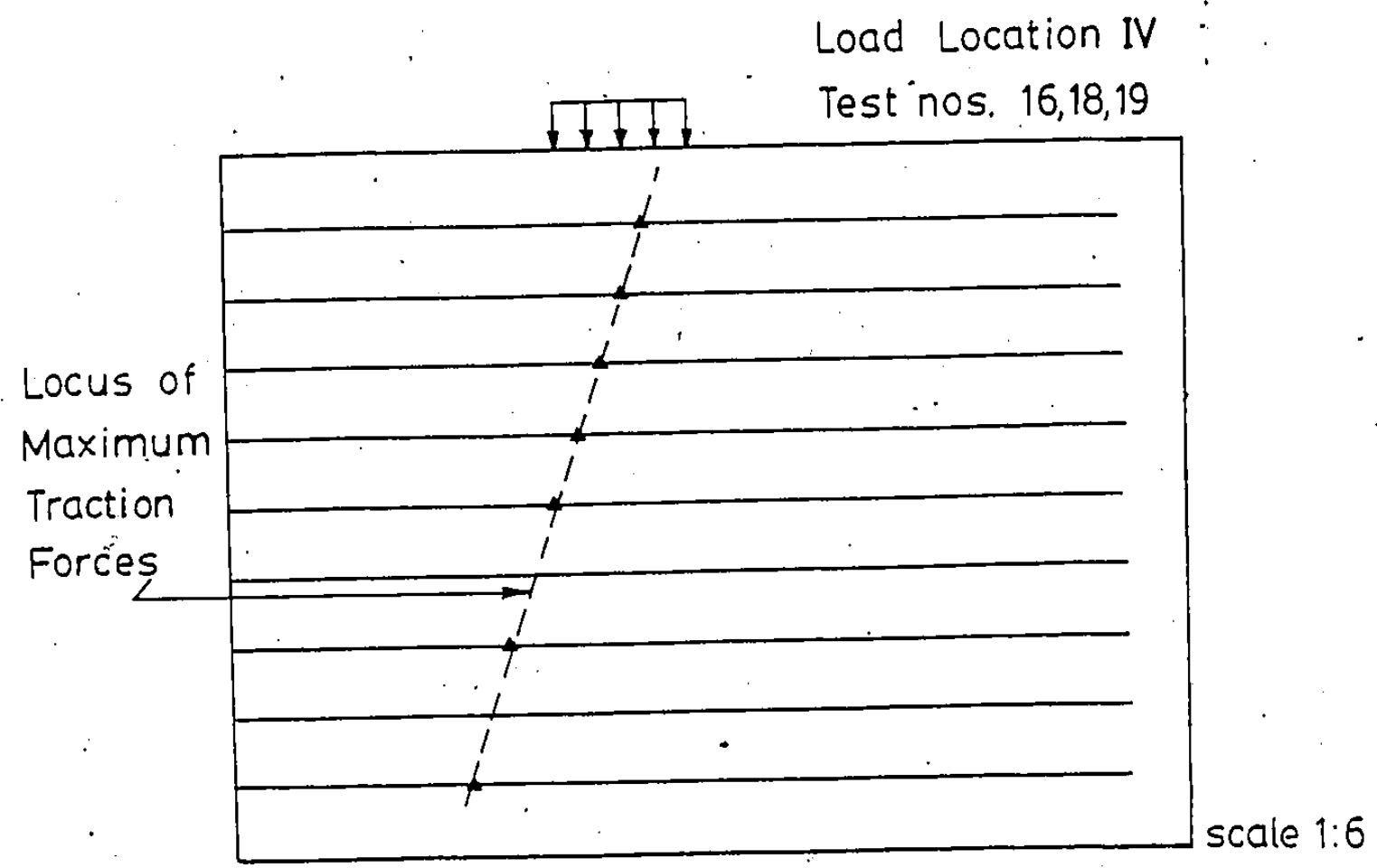

F1g. 4.16 Location of Maximum Traction Forces. 


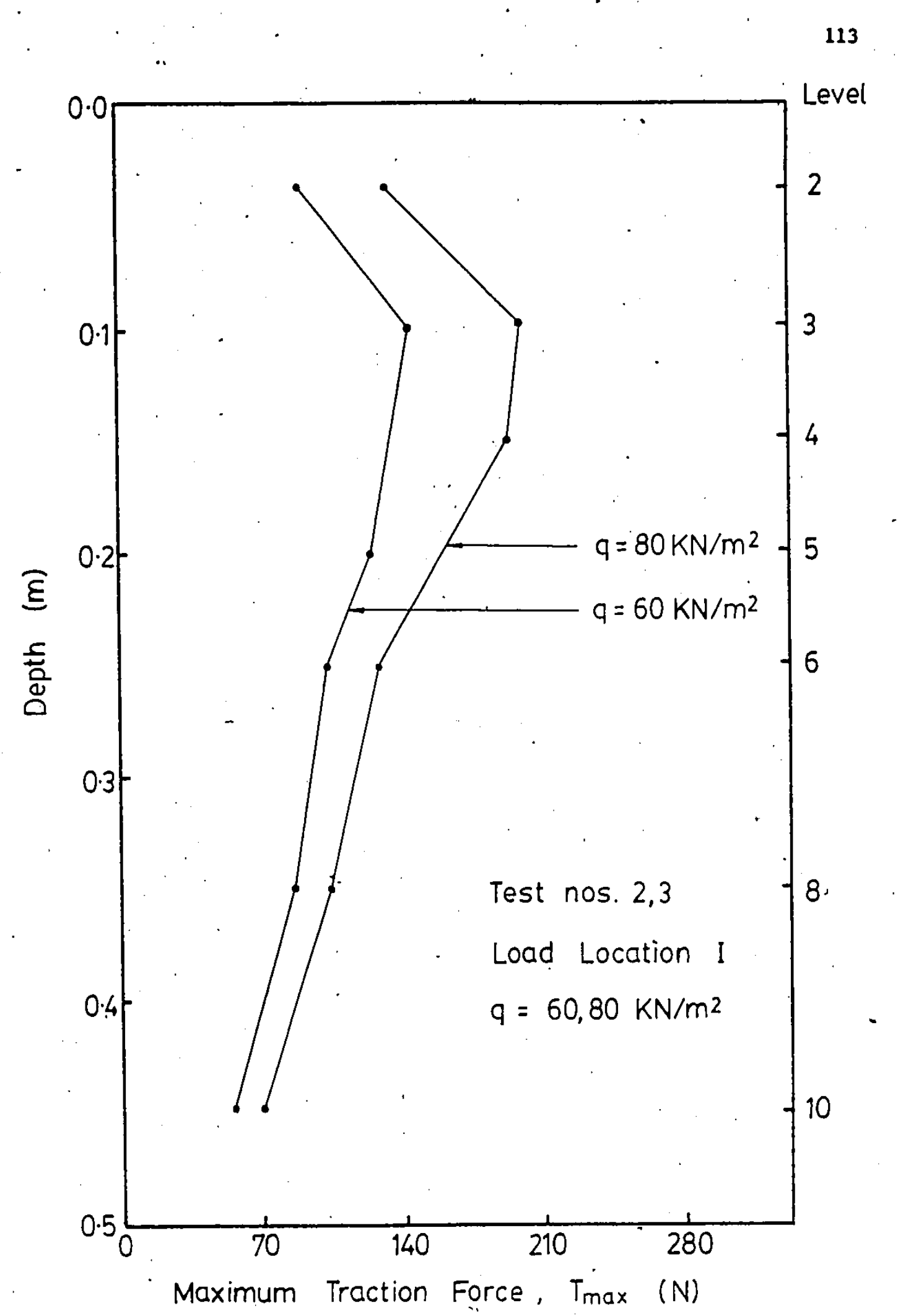

F18. 4.17 Distribution of. Maximum Strip Traction Force with Depth. 


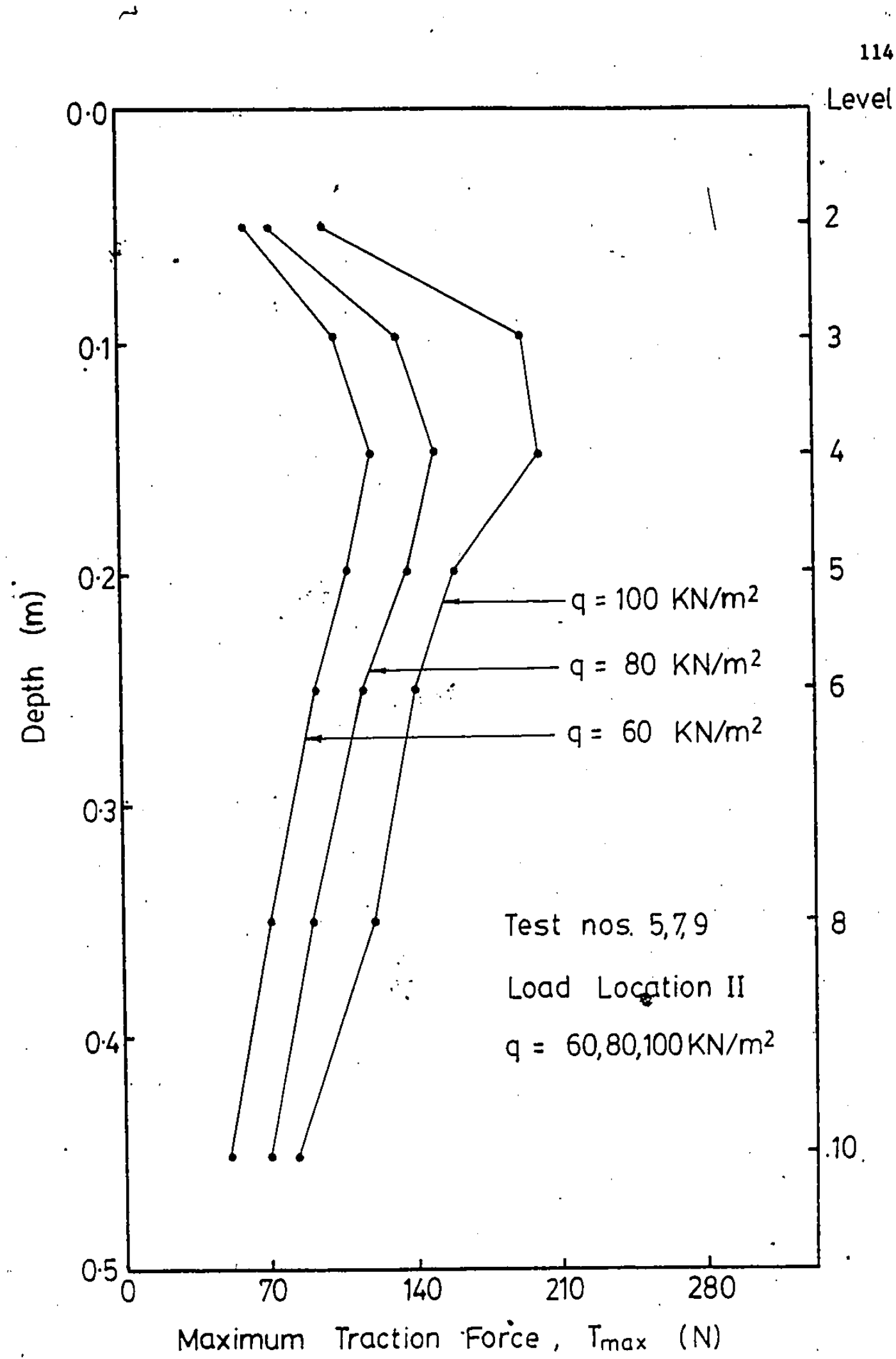

F1g. 4.18 Distribution of Maximum Strip Traction Force with Depth. 
115

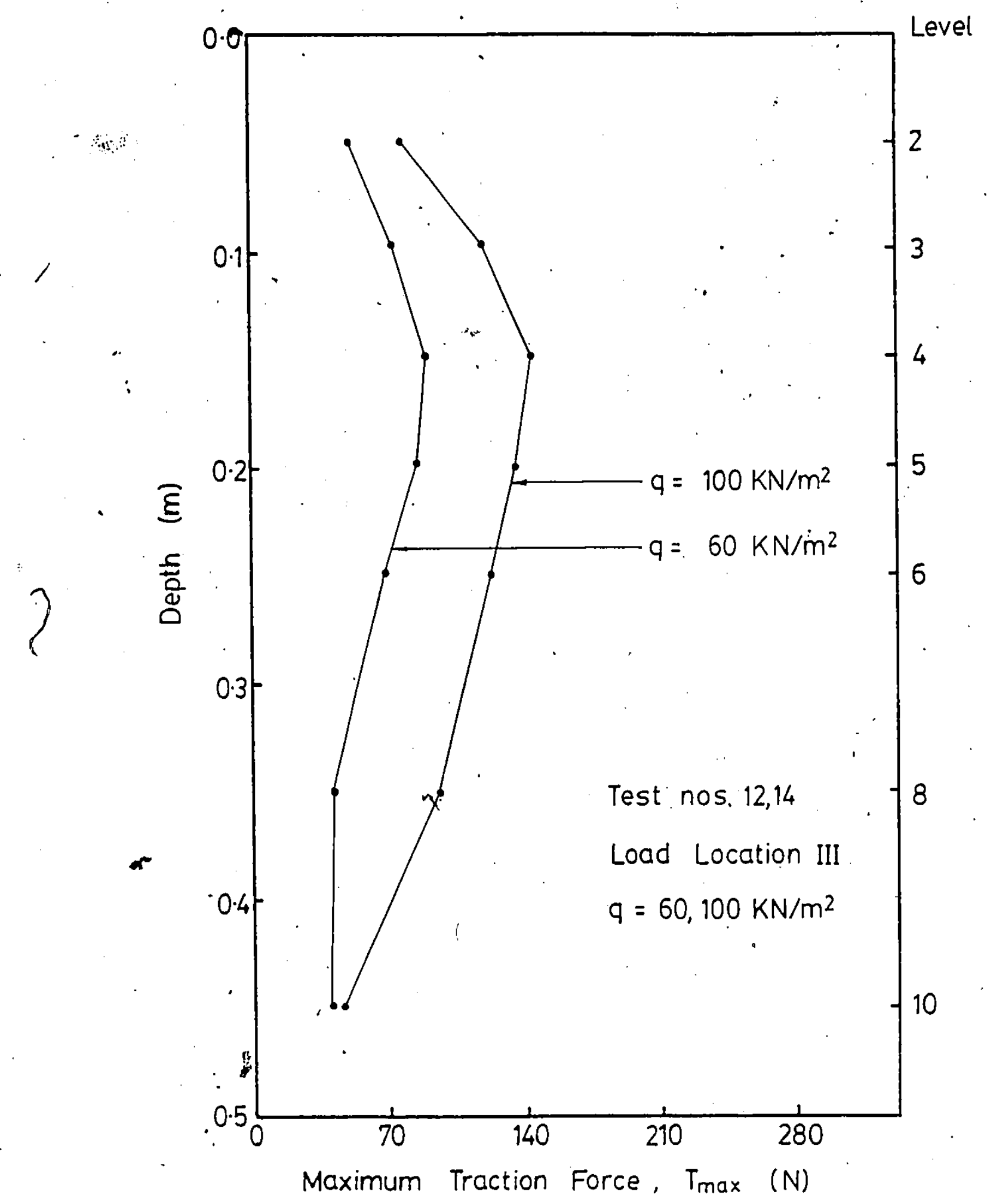

Fig. 4.19 Distribution of Maximum Strip Traction Force with Depth. 


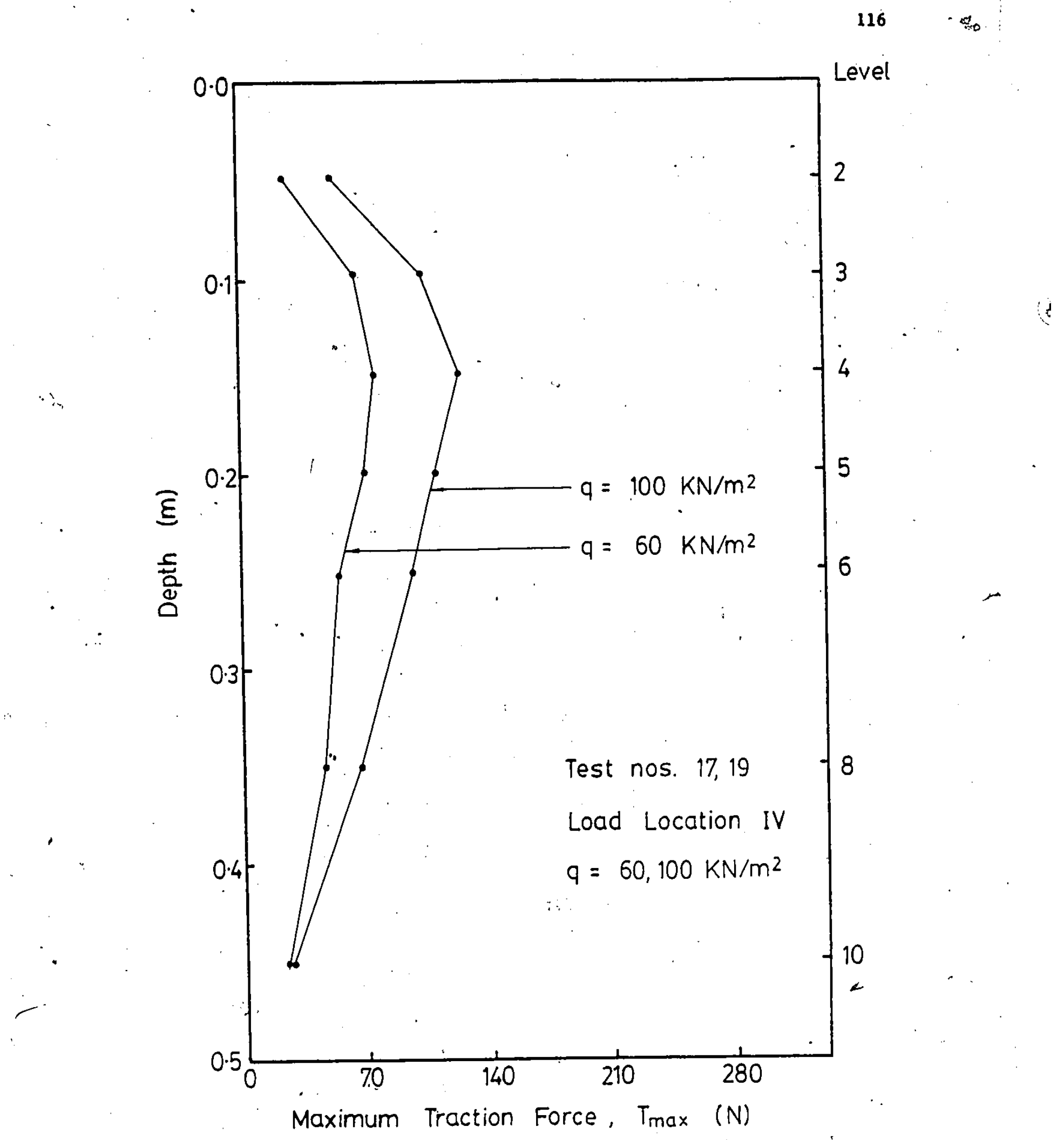

F1g. 4.20 Distribution of Maximum Strip Traction Force with Depth. 


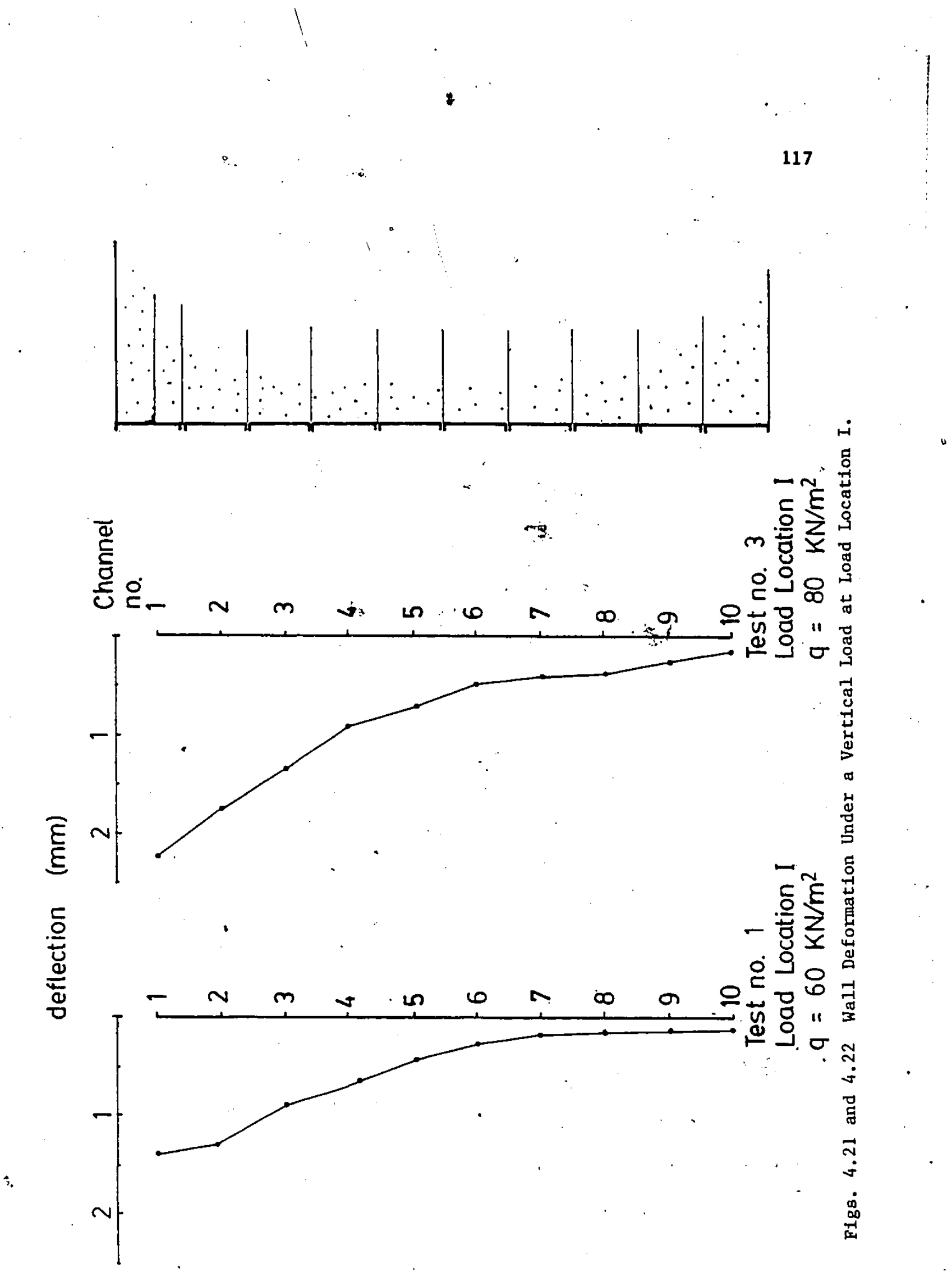




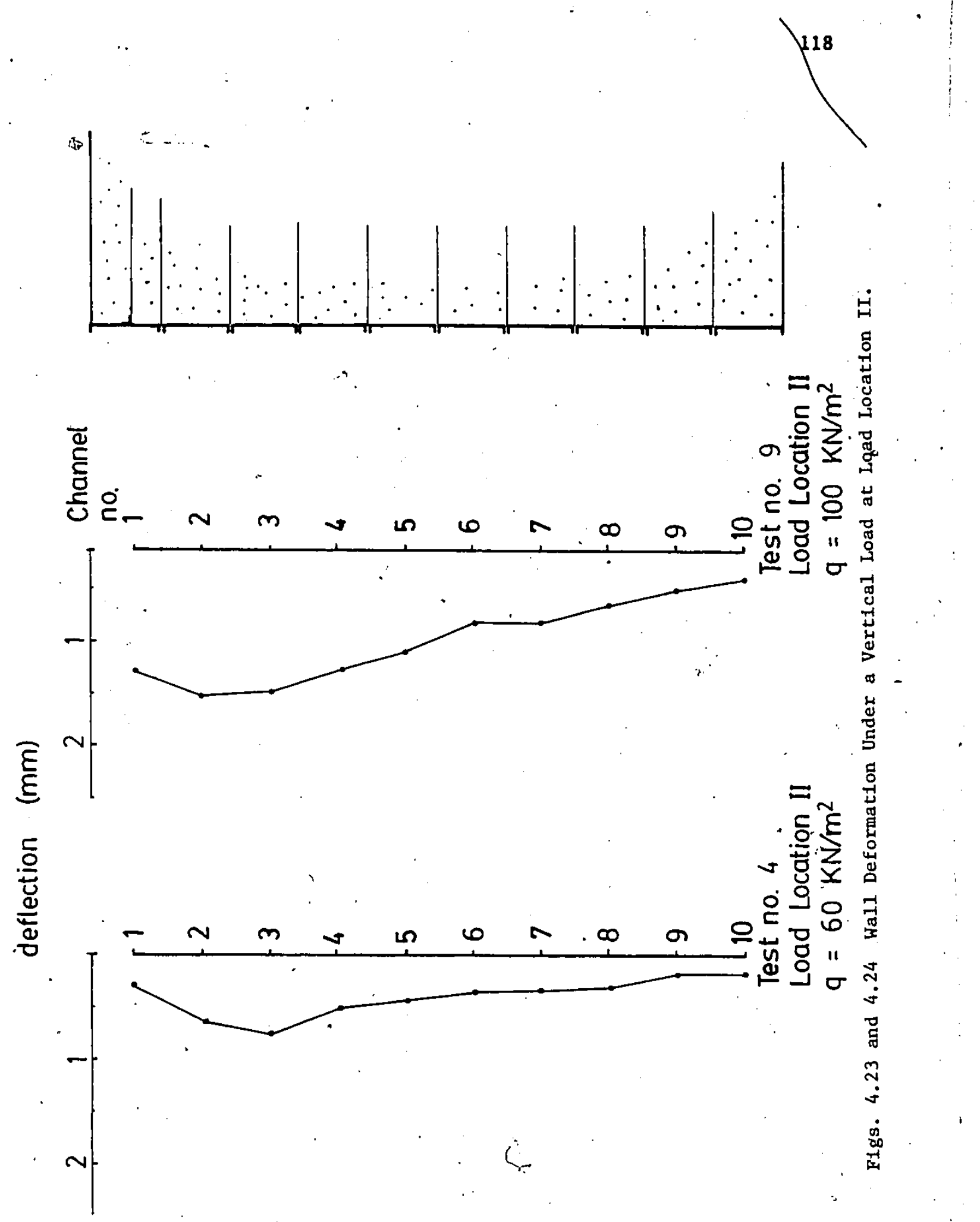


3
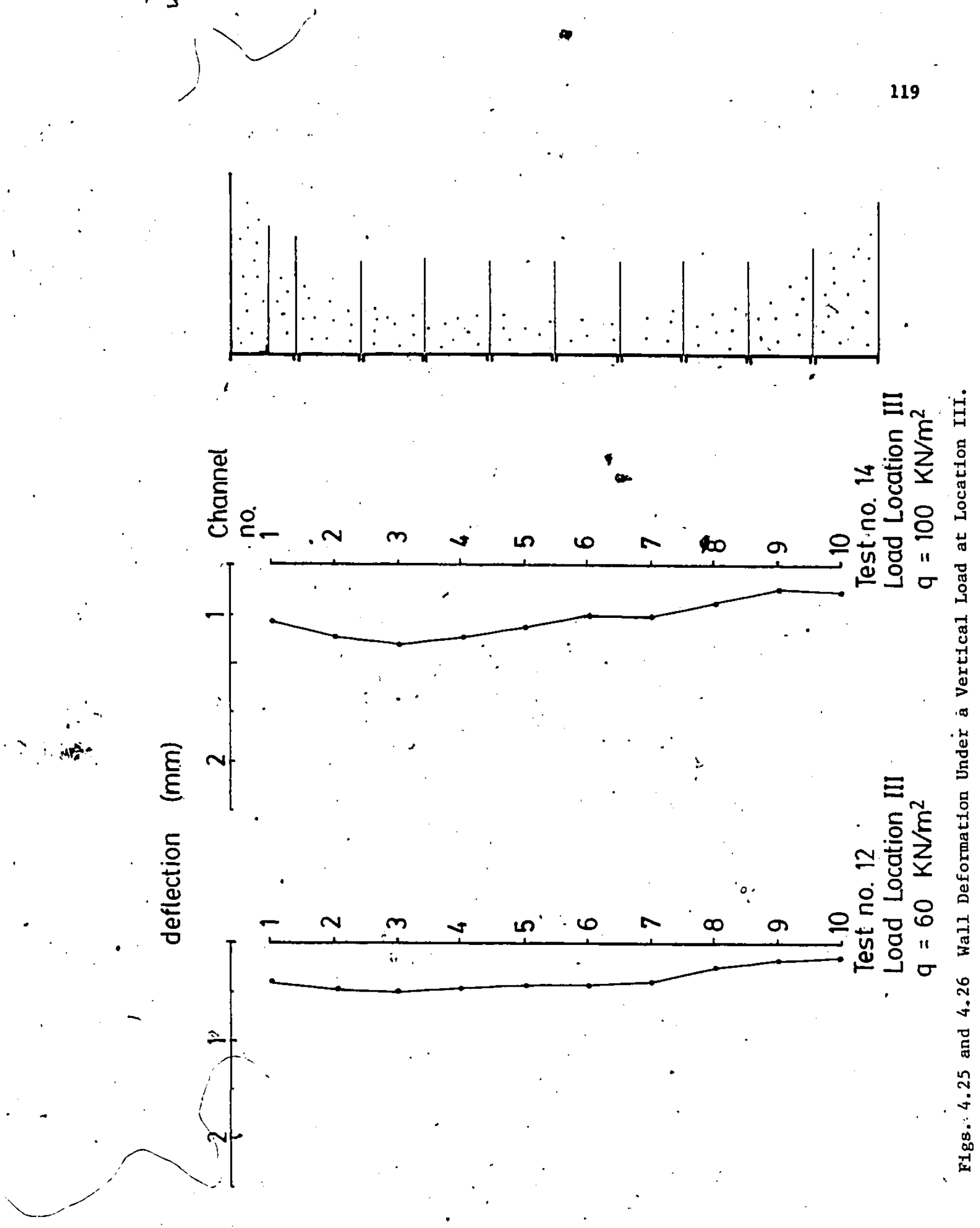


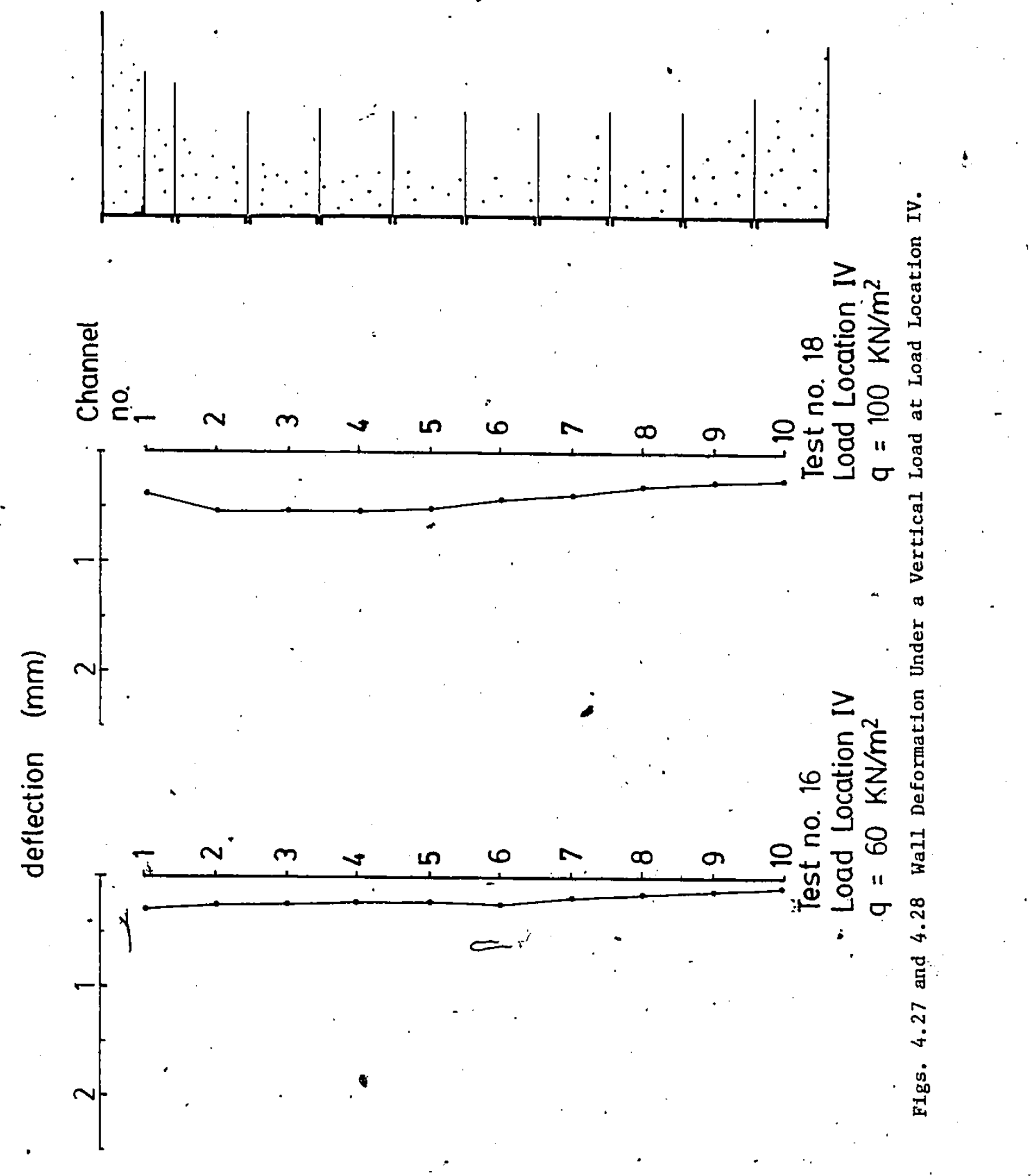




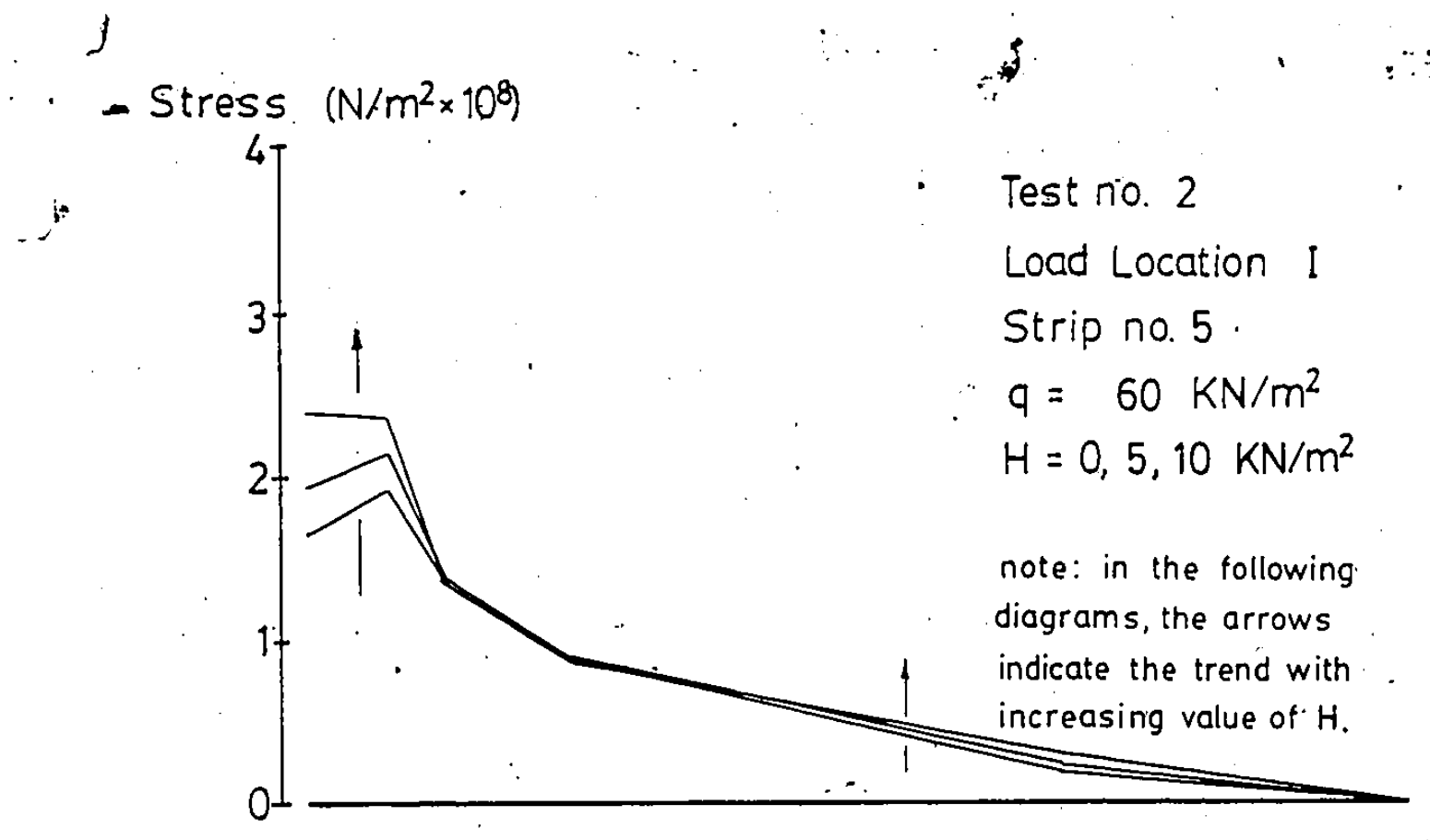

F1g. 4.29 Change in Strip Traction Force due to Horizontal Load Component.

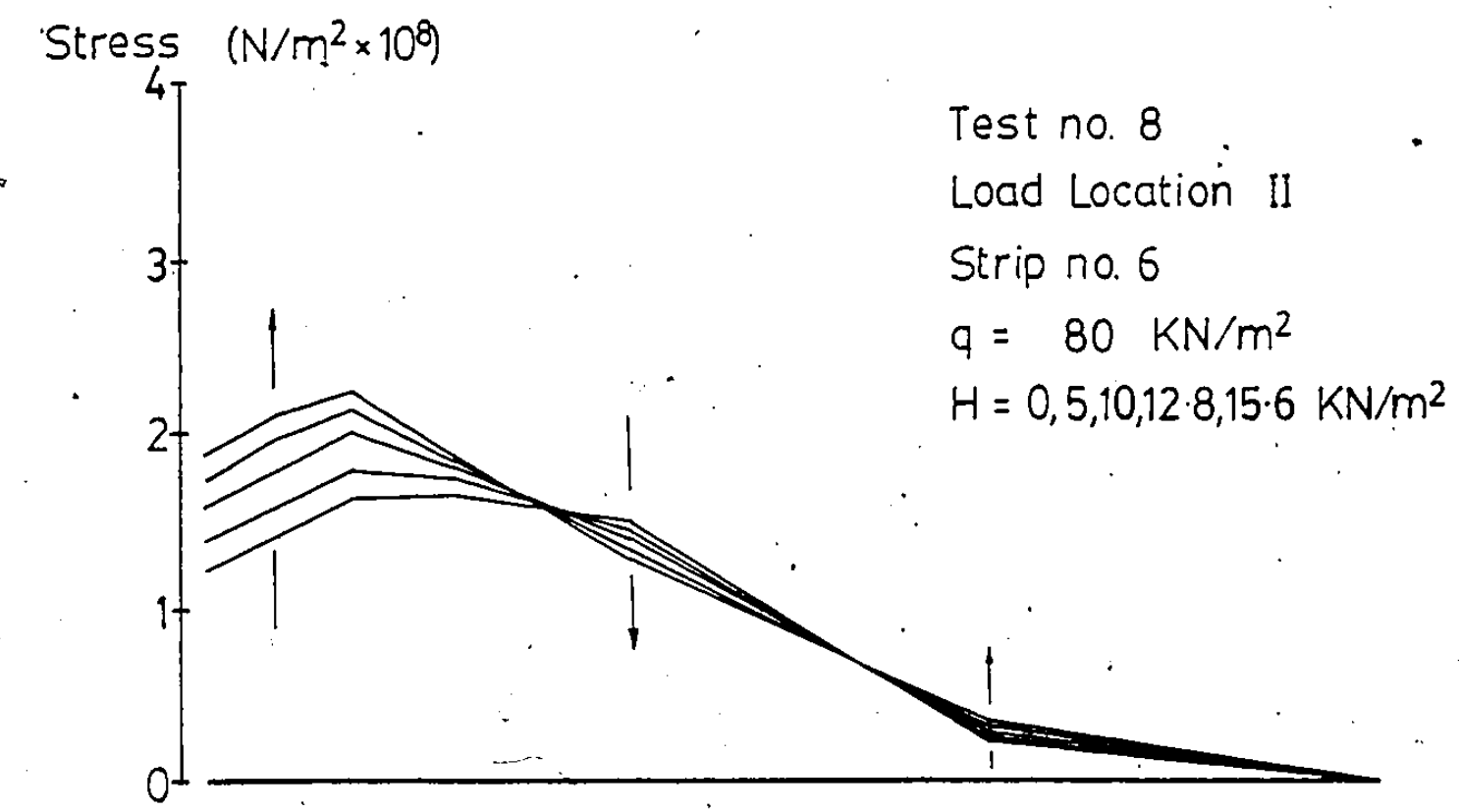

F1g. 4.30 Change in Strip Traction Force due to Horizontal Load Component. 
Stress $\left(\mathrm{N} / \mathrm{m}^{2} \times 10^{8}\right)$

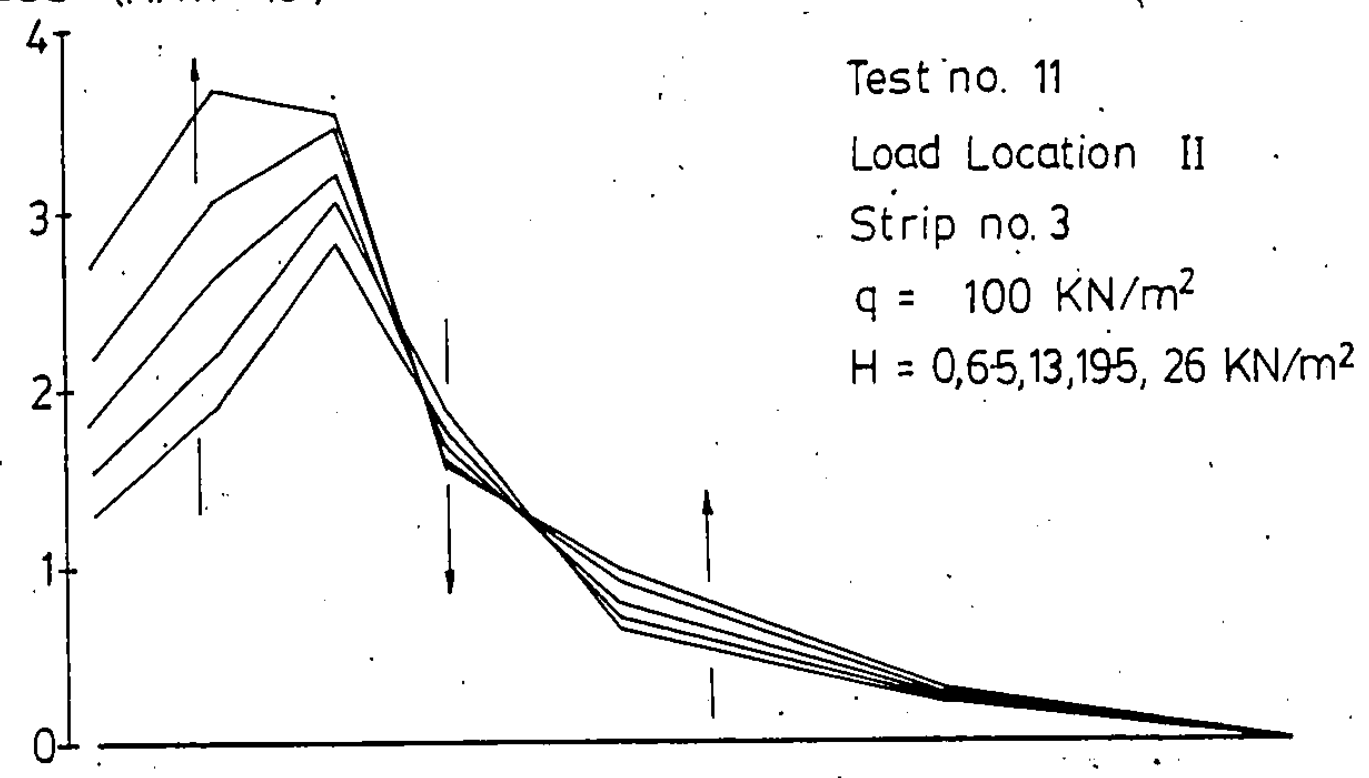

F1g. 4.31 Change in Strip Traction Force due to Horizontal Load Component.

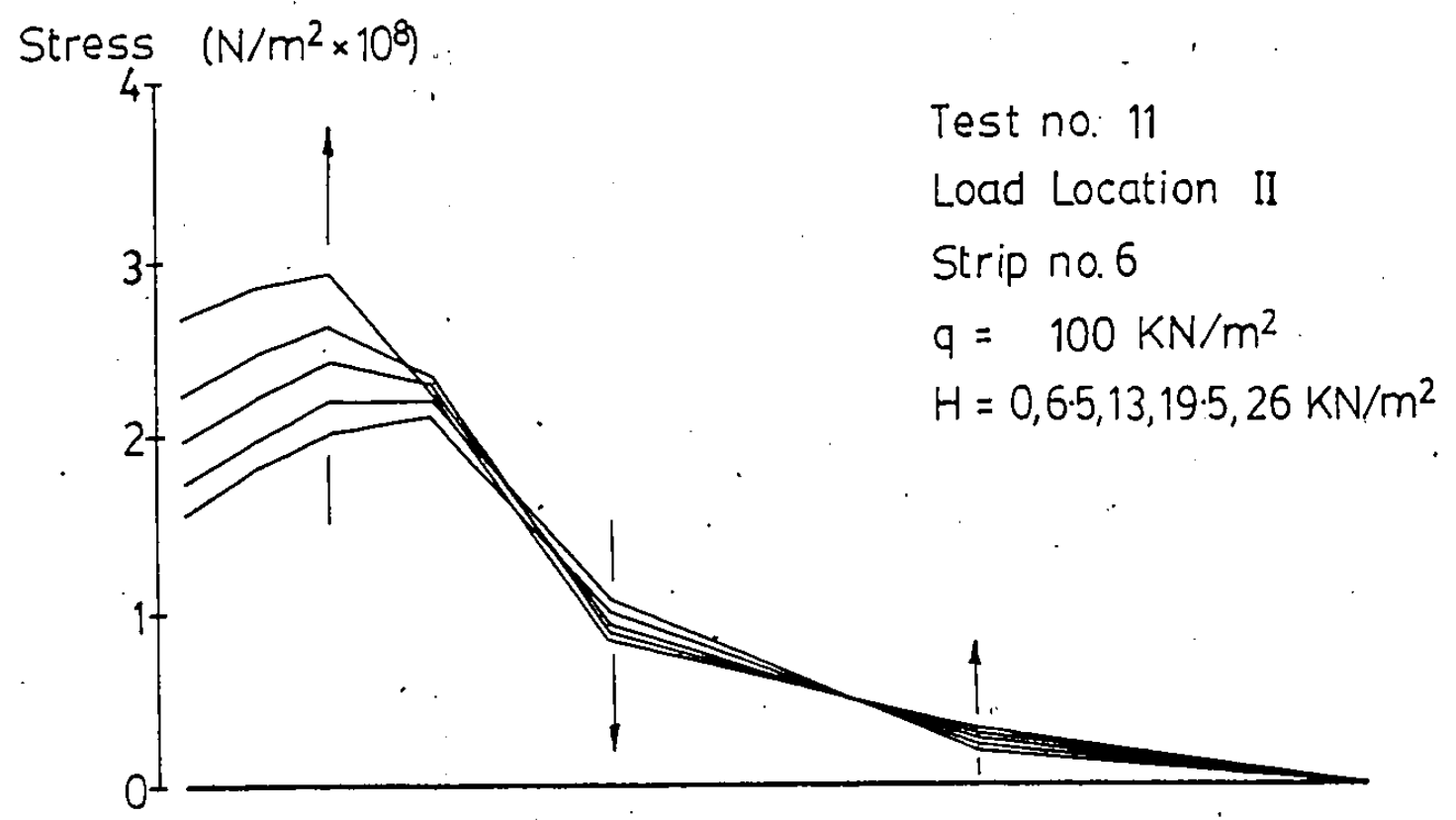

F1g. 4.32 Change in Strip Traction Force due to Horizontal Load Component. 
Stress $\left(\mathrm{N} / \mathrm{m}^{2} \times 10^{8}\right)$

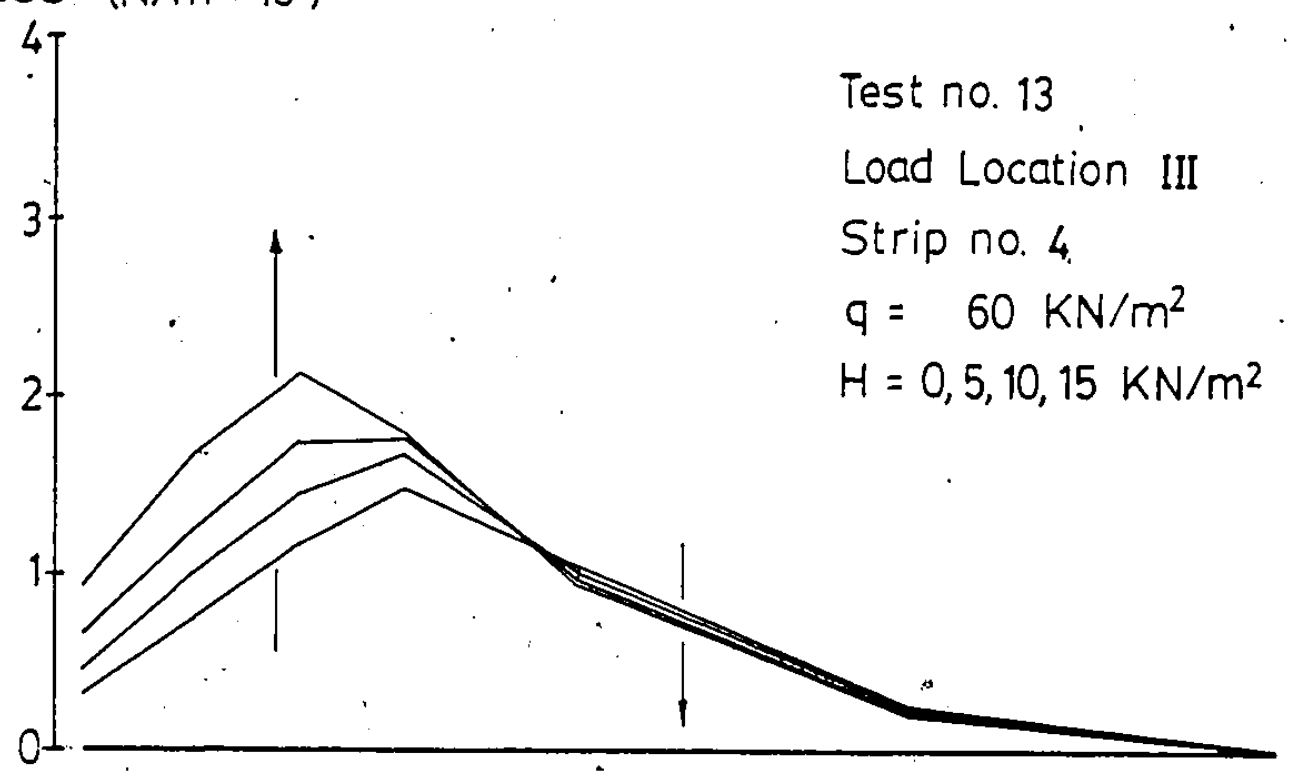

F1g. 4.33 Change in Strip Traction Force due to Horizontal Load Component.

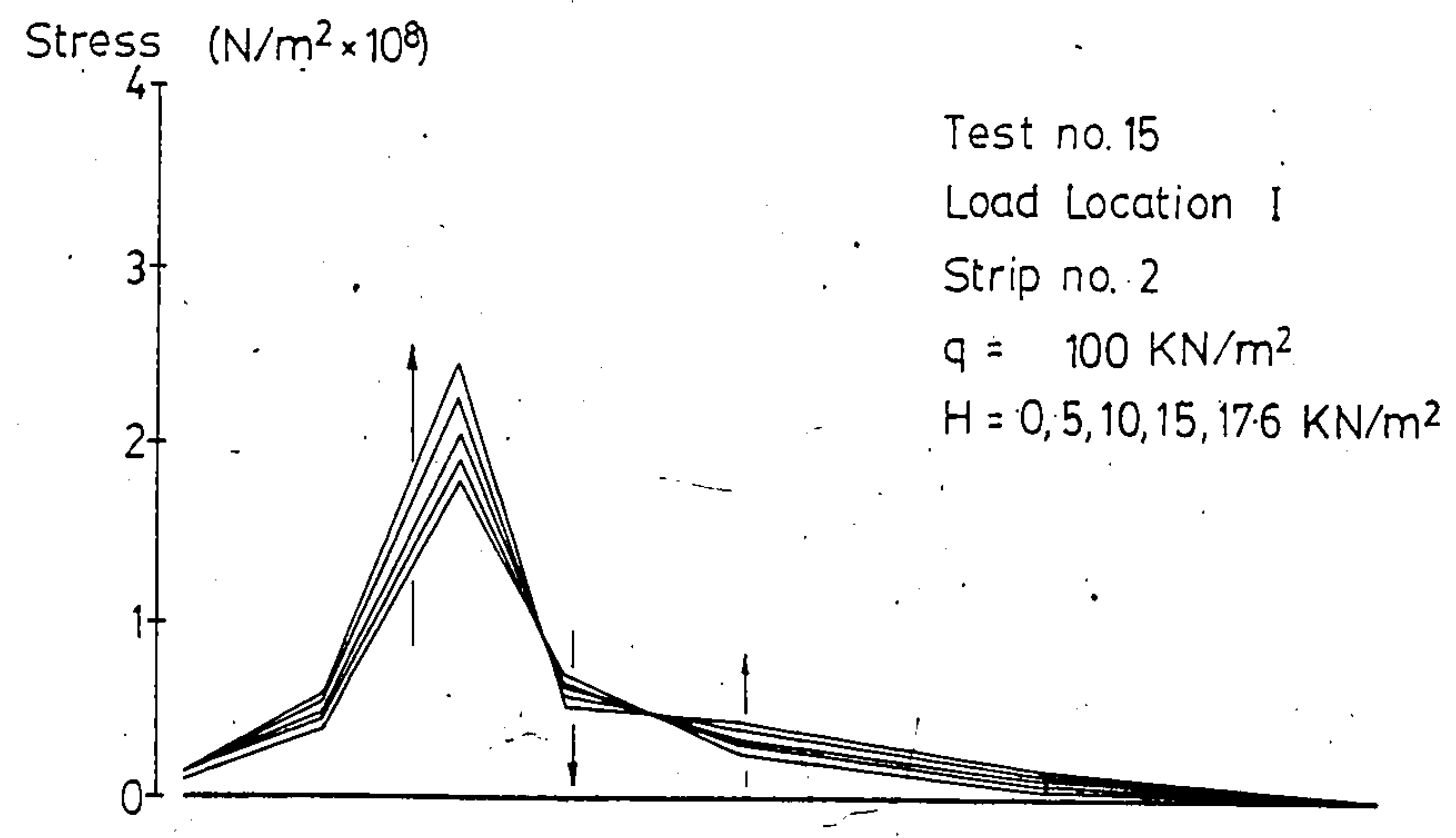

F1g. 4.34 Change in Strip Traction Force due to Horizontal Load Component. 
Stress $\left(\mathrm{N} / \mathrm{m}^{2} \times 10^{8}\right)$

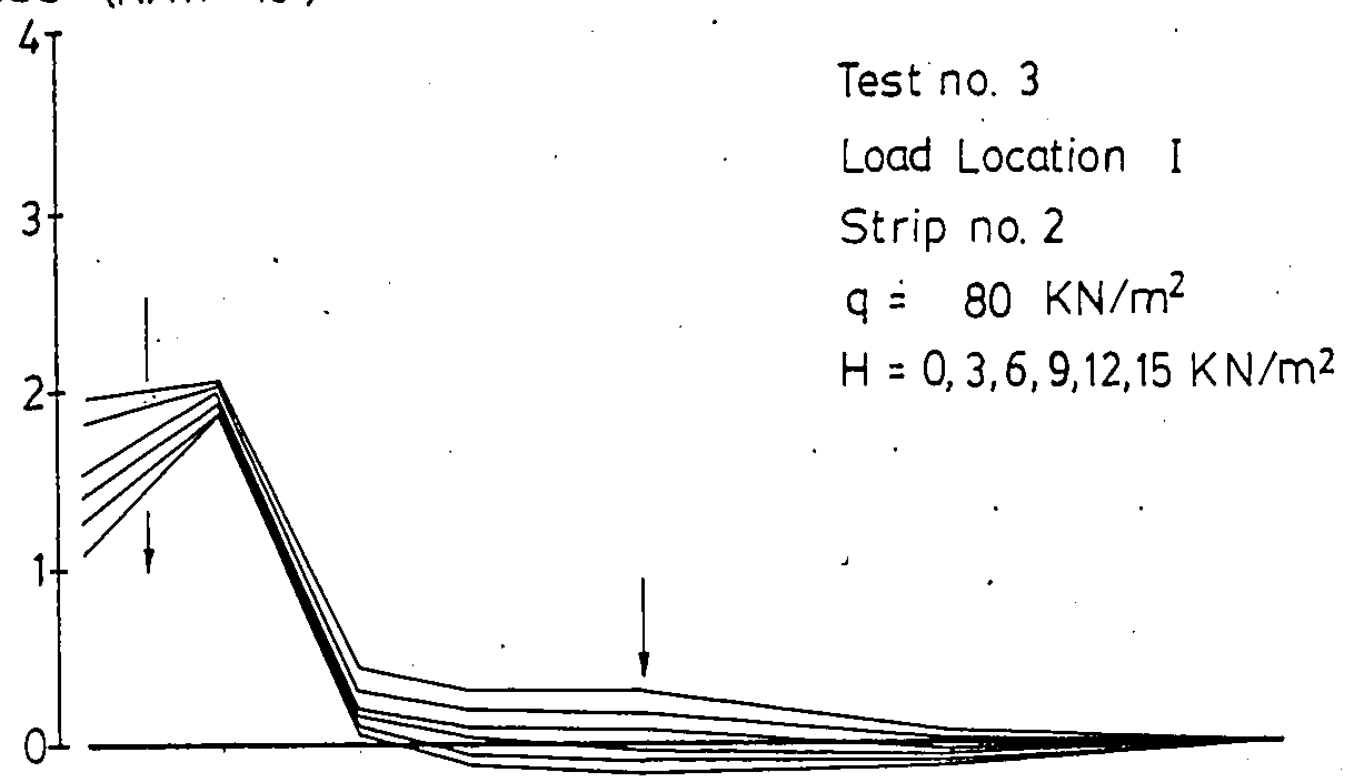

F18. 4.35 Change in Strip Traction Force due to Horlzontal Load Component.

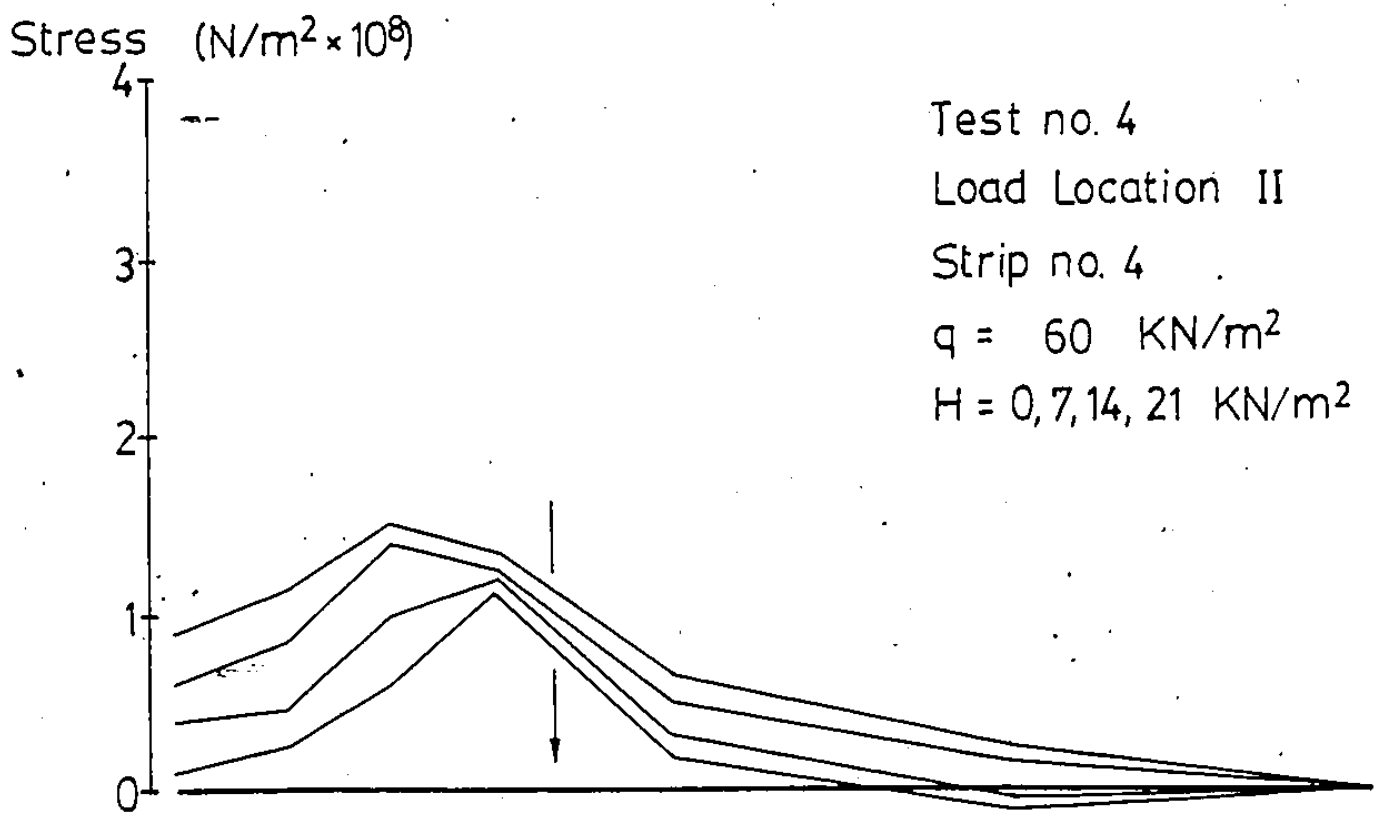

Fig. 4.36 Change in Strip Traction. Force due to Horizontal Load Component. 


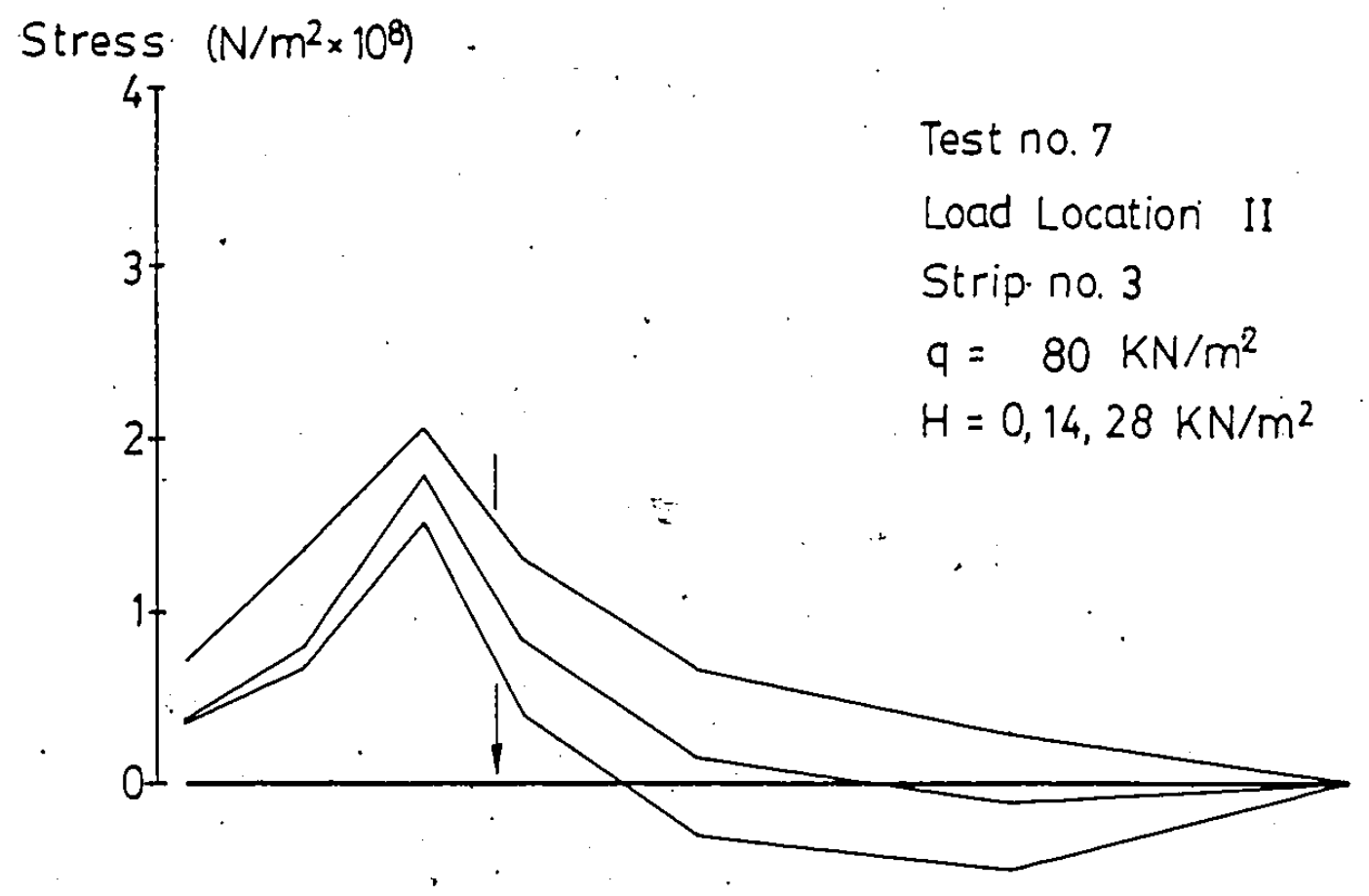

Fig. 4.37 Change In Strip Traction Force due to Horizontal Load Component.

Stress $\left(N / m^{2} \times 10^{8}\right)$

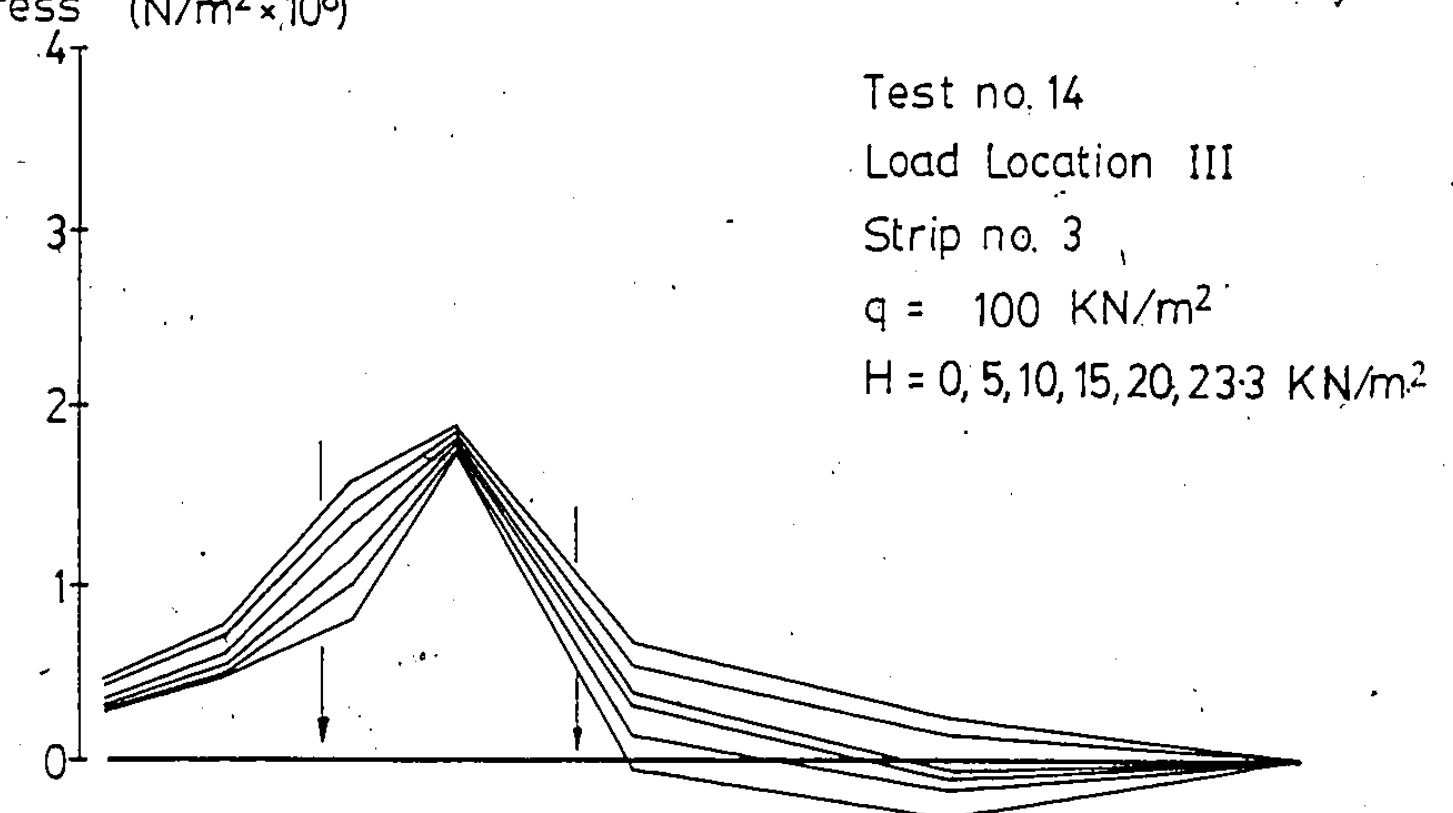

Fig. 4.38 Change in Strip Traction Force due to Horizontal Load Component. 


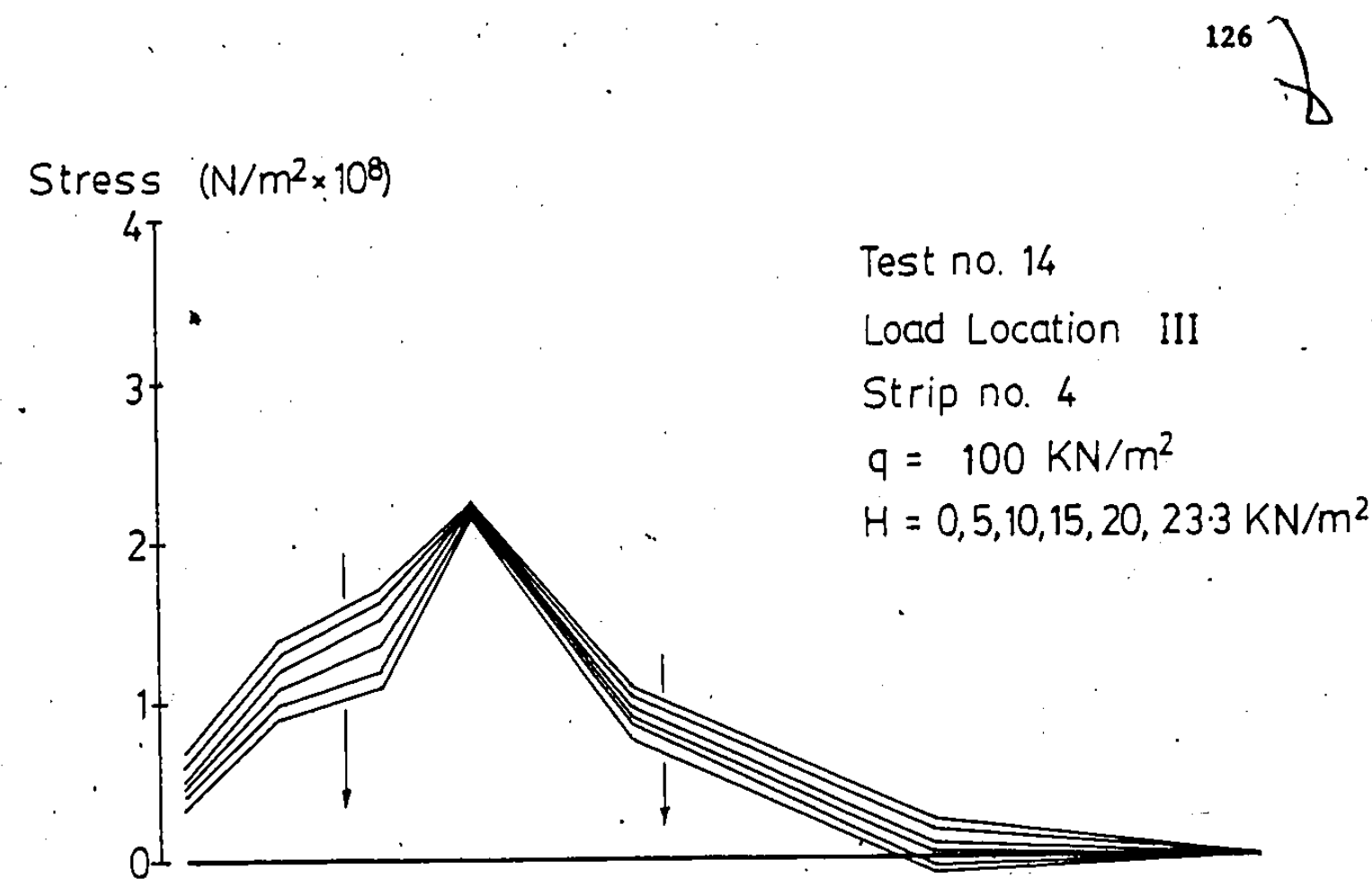

Fig., 4.39 Change in Strip Traction Force due to Horizontal Load Component.

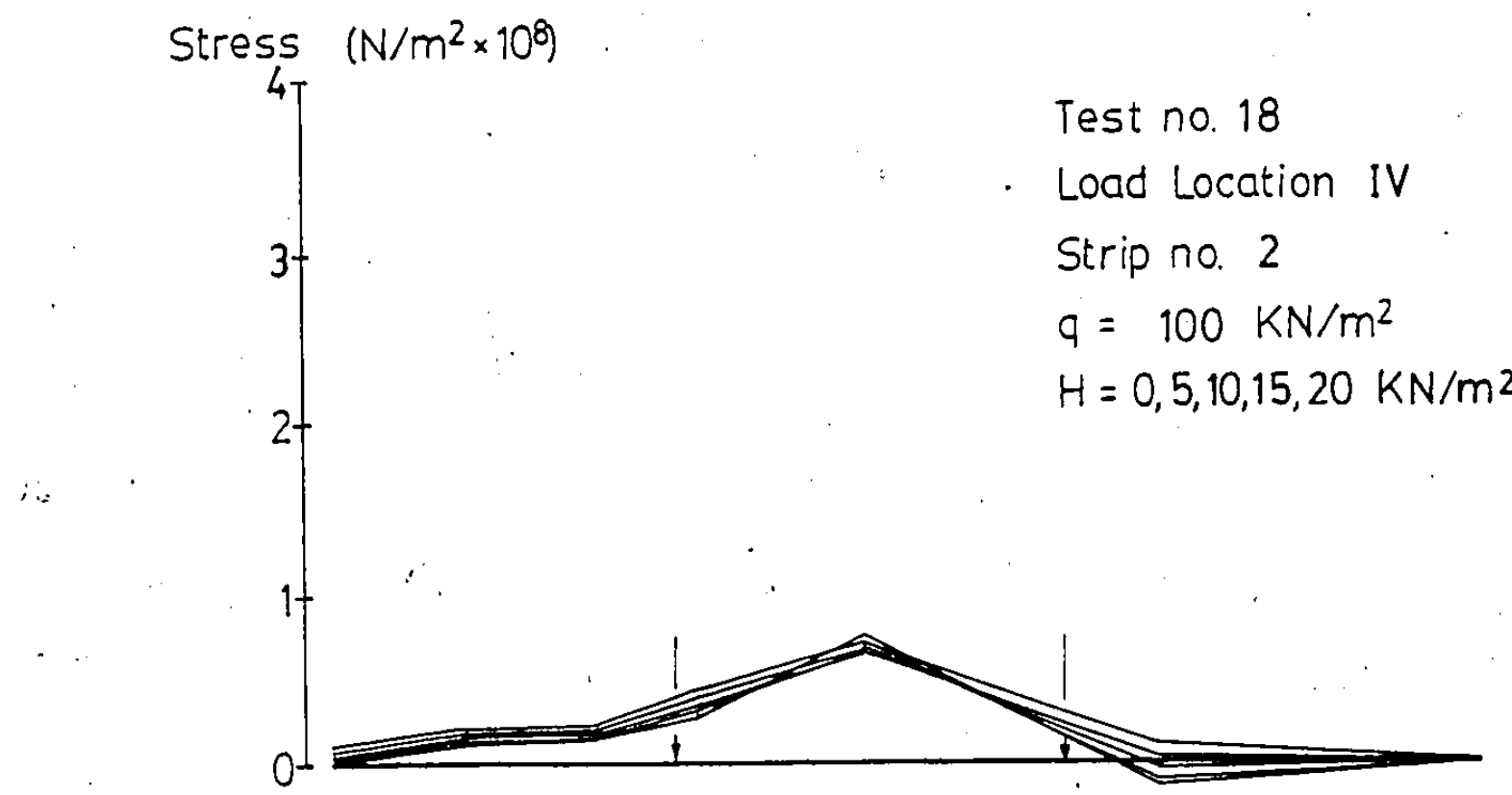

Fig. 4.40 Change in Strip Traction Force due to Horizontal Load Componenit. $\because$ 


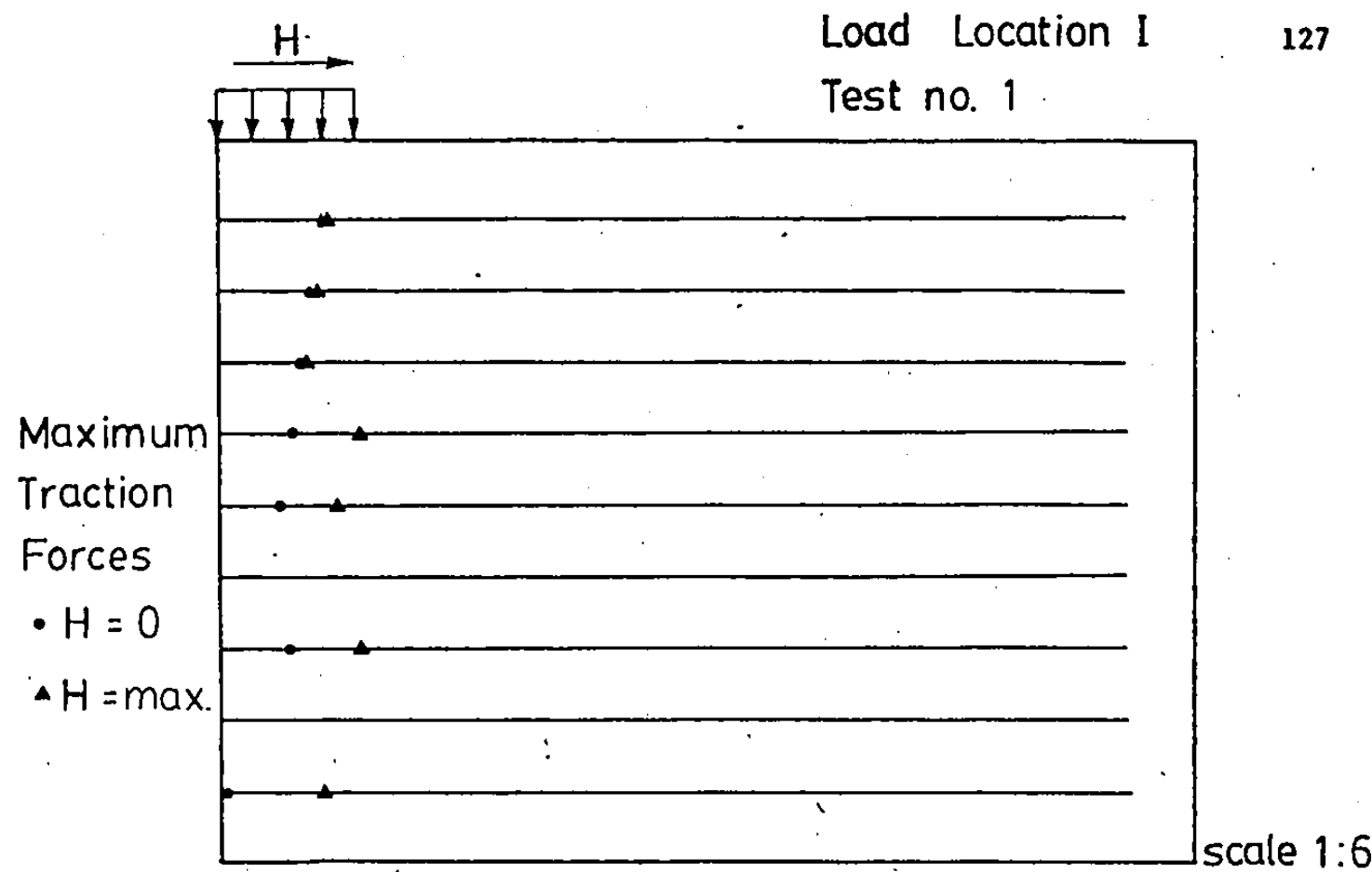

Fig. 4.41 Shift in Position of Maximum Traction Forces.

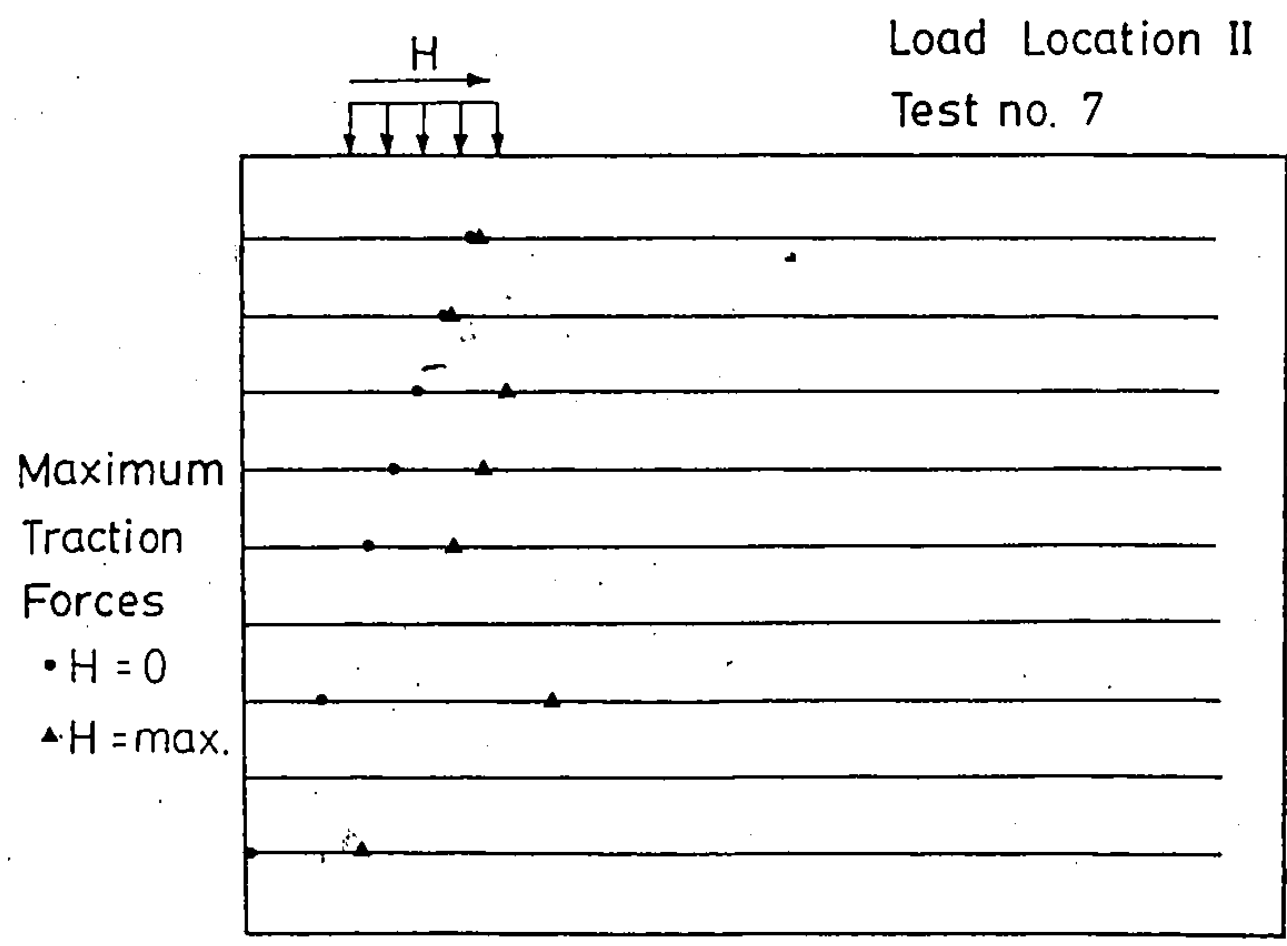

Fig. 442 Shift in Posttion of Maximum Traction Forces. 


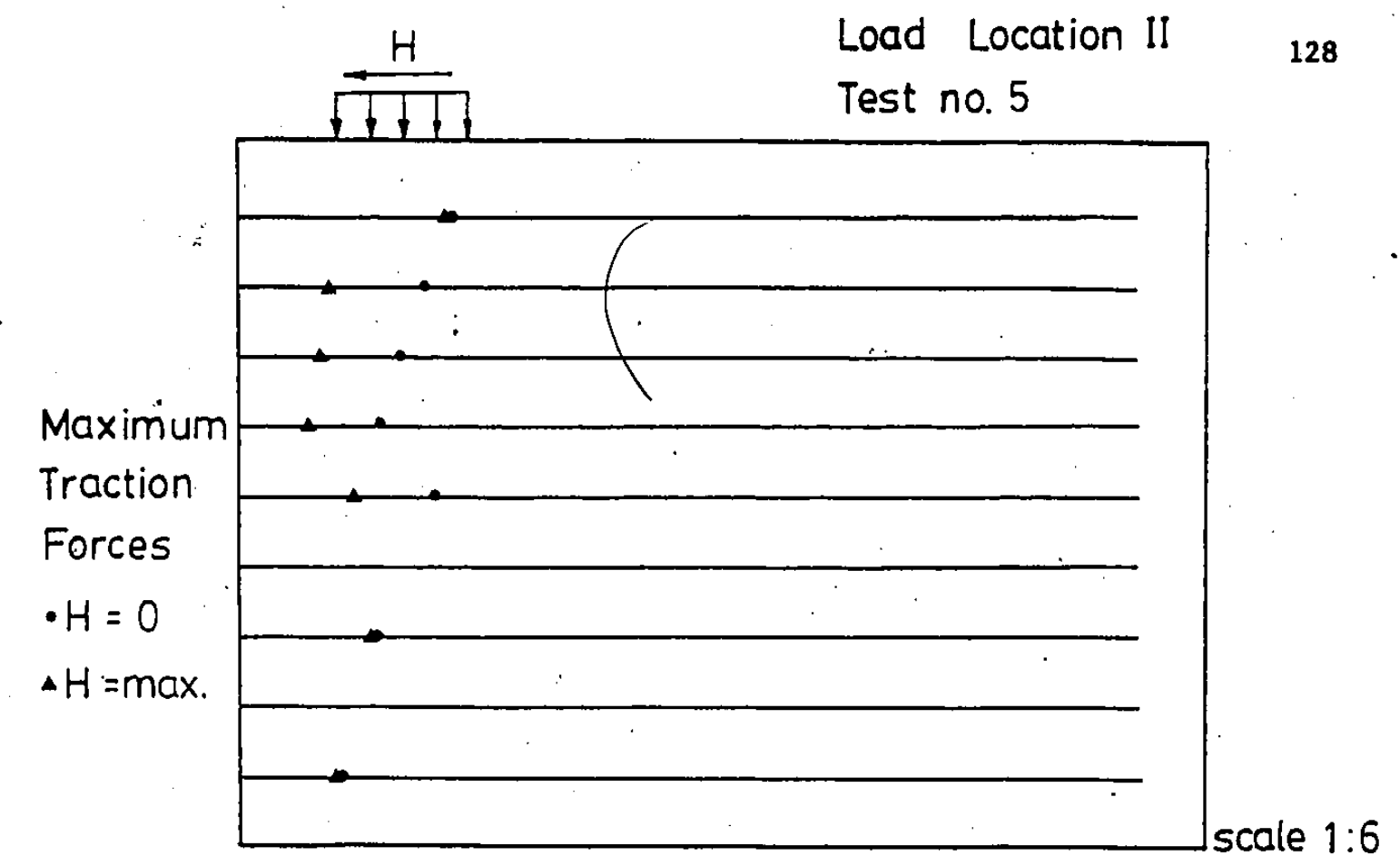

Fig. 4.43 Sh1ft in Position of Maximum Traction Force.

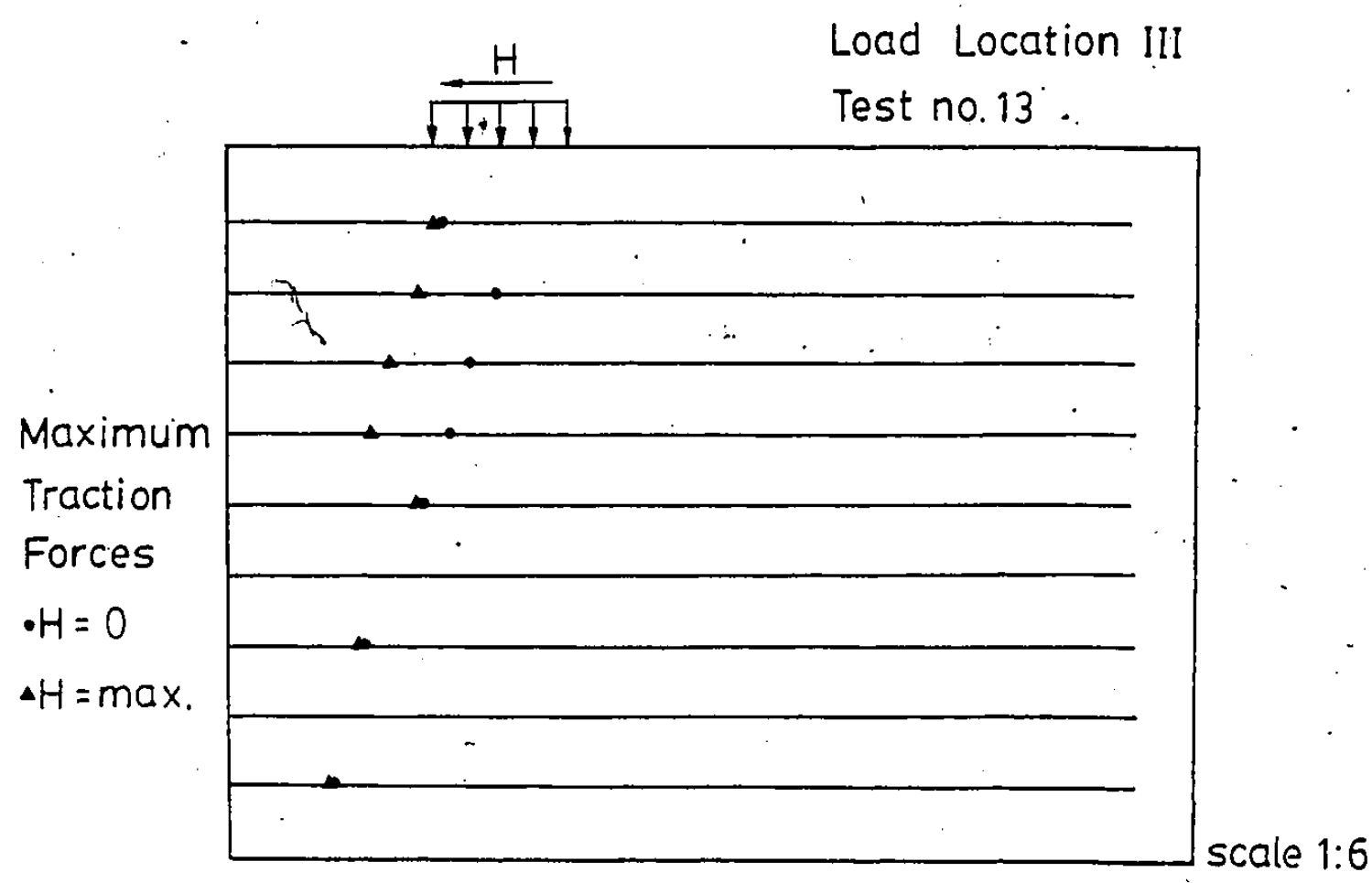

F1g. 4.44 Shift in Position of Maximum Traction Force. 


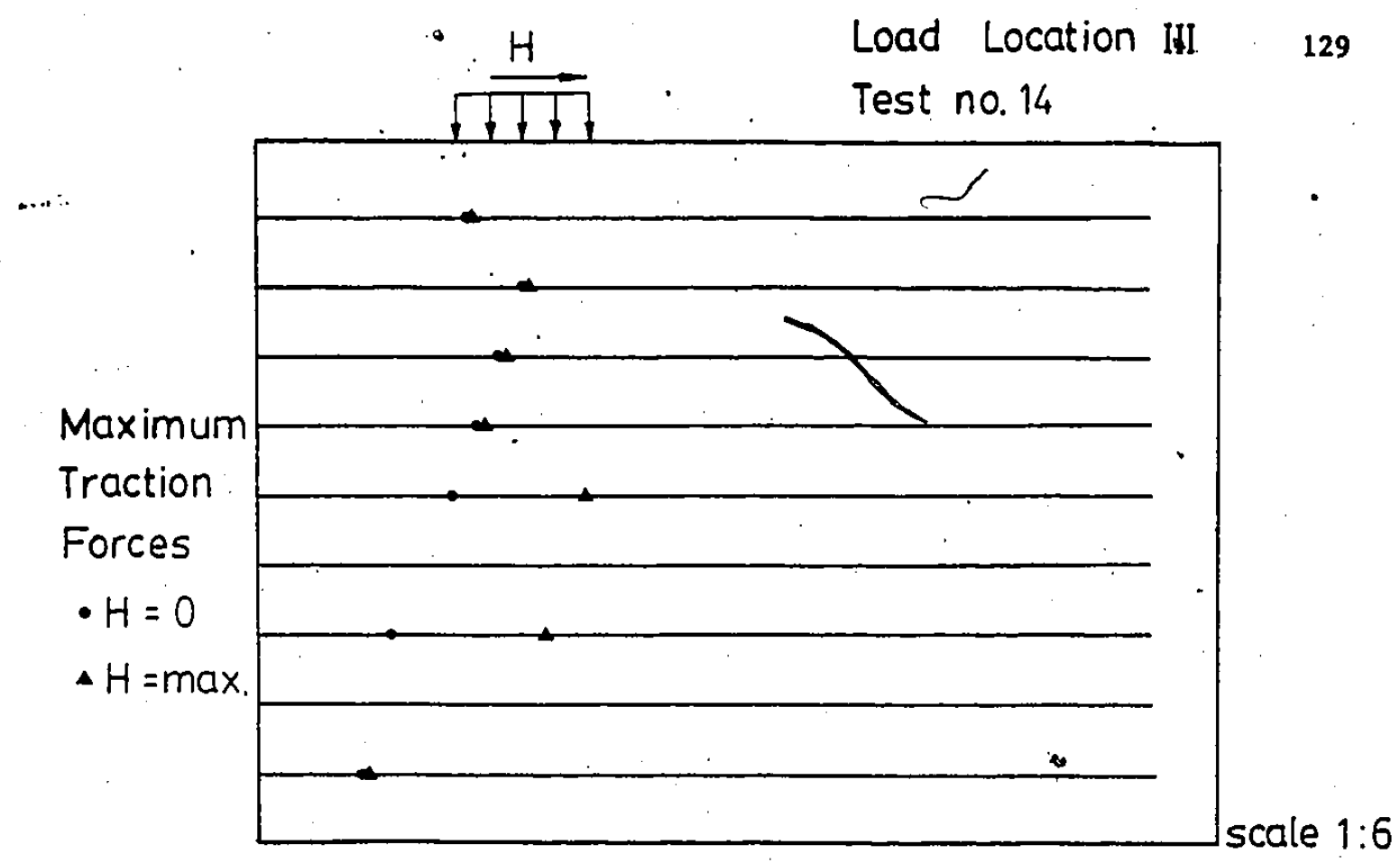

F18. $4.45^{\circ}$ Shift in Position of Maximum Traction Force.

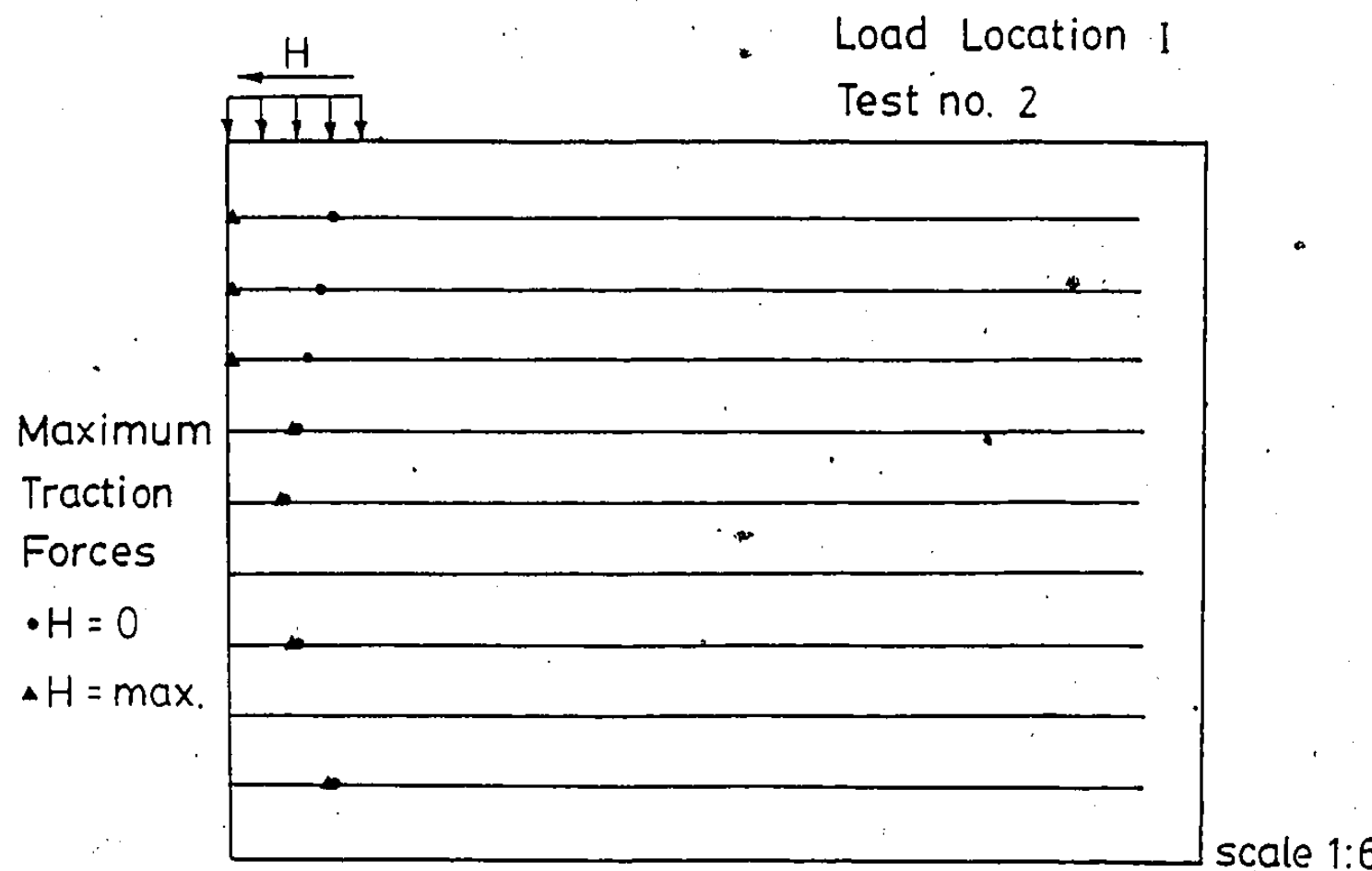

$\therefore$ FIg. 4.46 Shift in Position of Maximum Traction Force. 


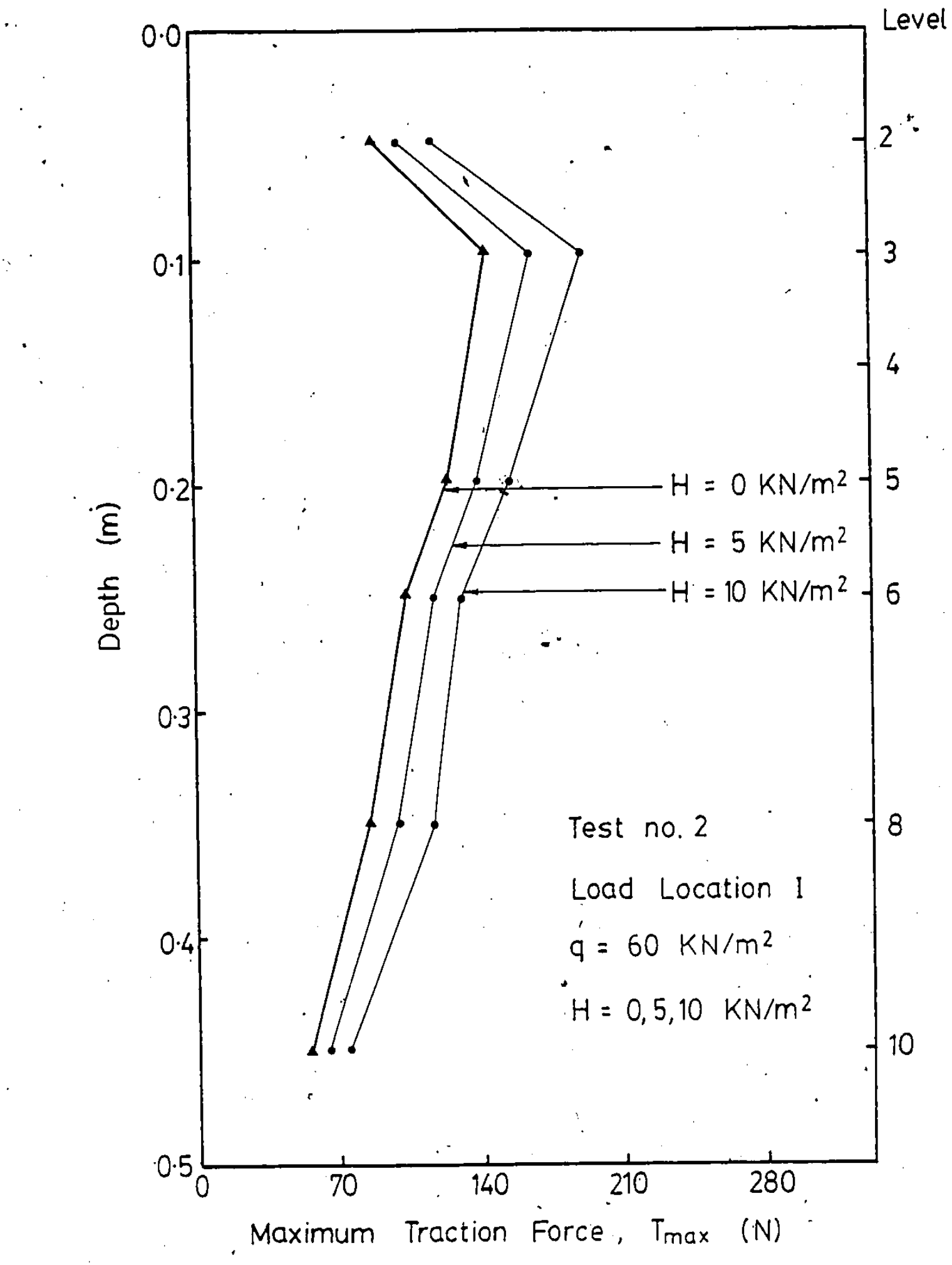

Fig. 4.47 Effect of Horizontal Component on Distributicn of Maximum Strip Traction Force with Depth. 


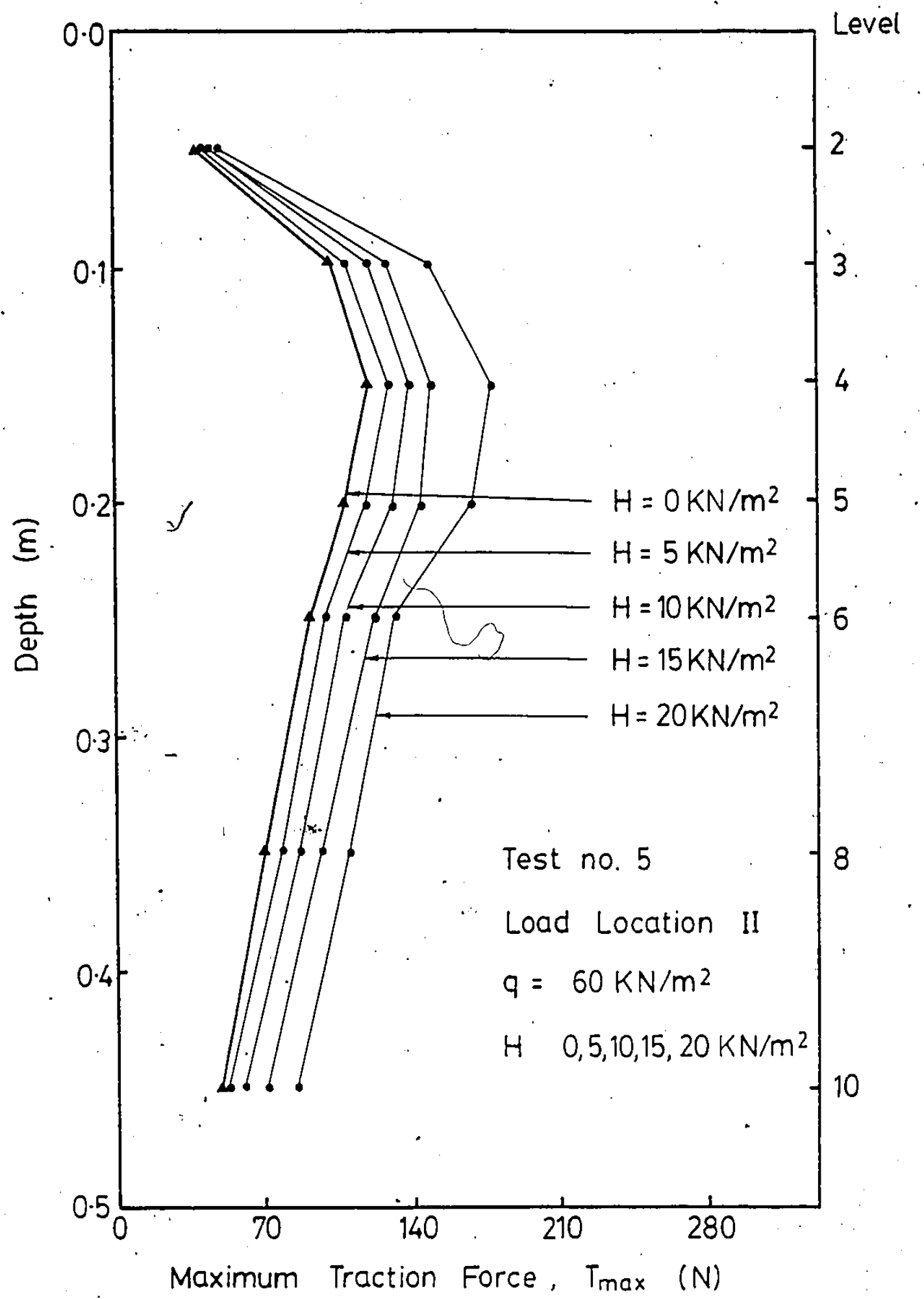

Fig. 4.48 Effect of Horizontal Component on Distribution of Maximum Strip Traction Force with Depth. 


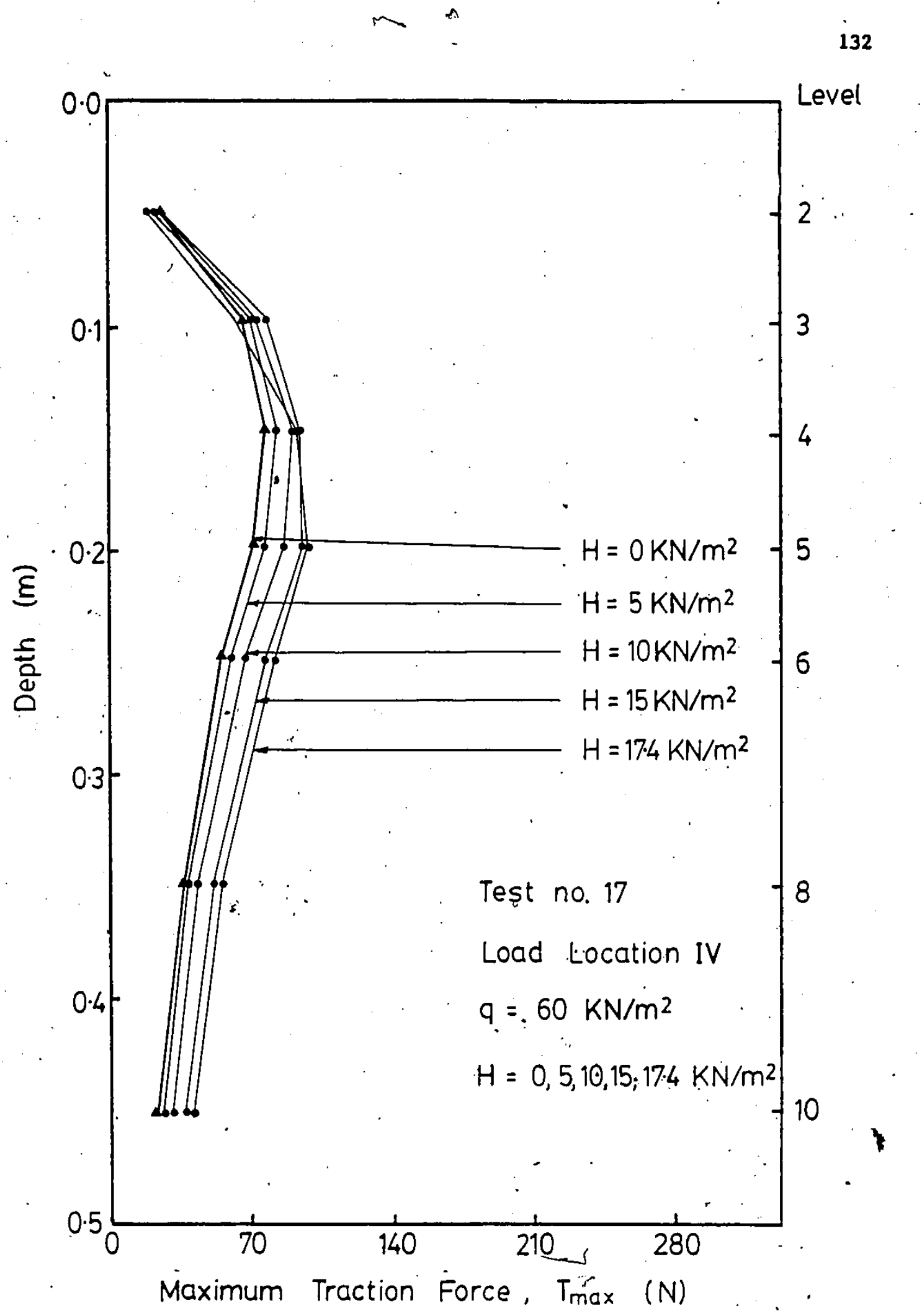

Fig. 4. 49 Effect of Horizontal Component on Distribution of Maximum Strip Traction Force with Depth. 


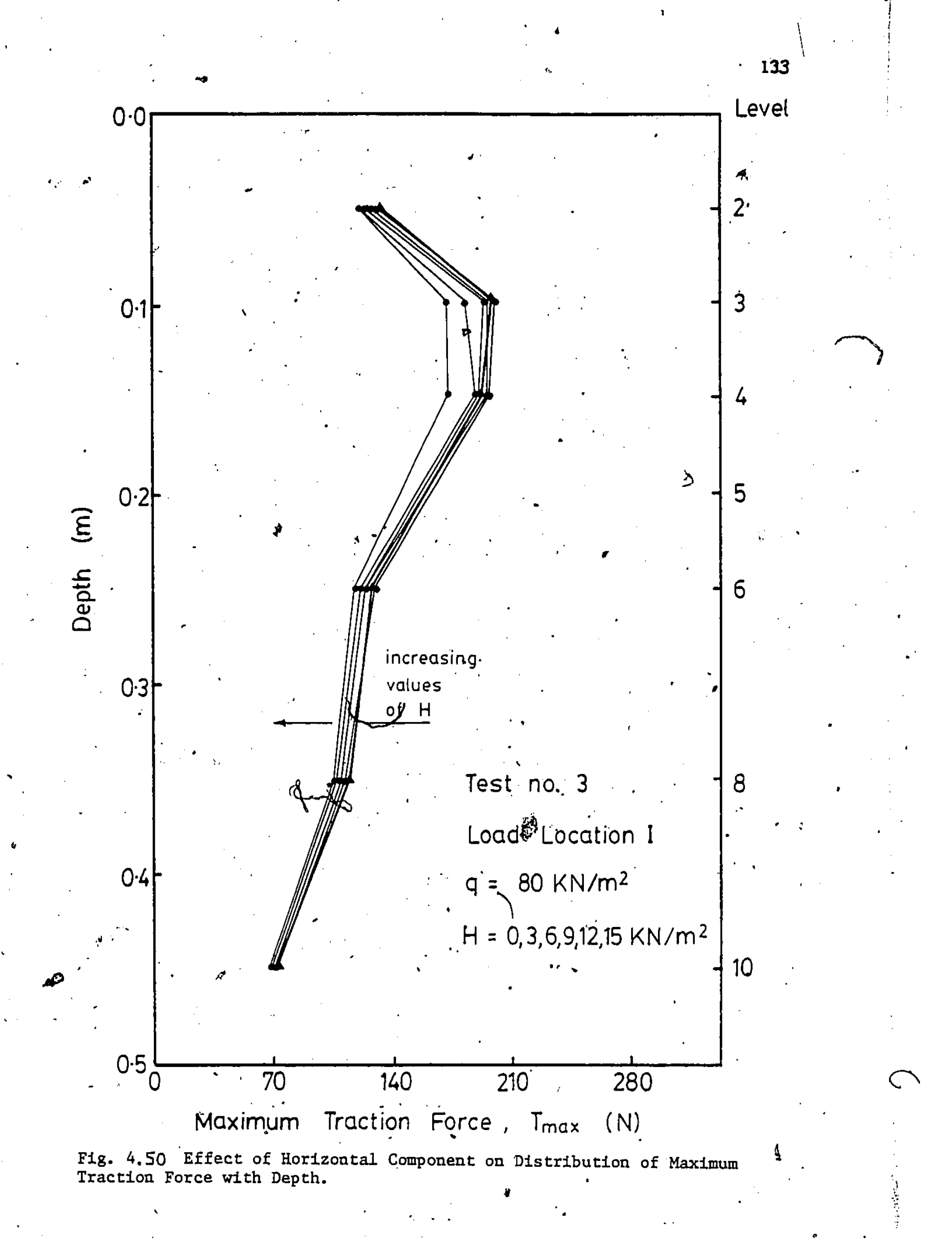




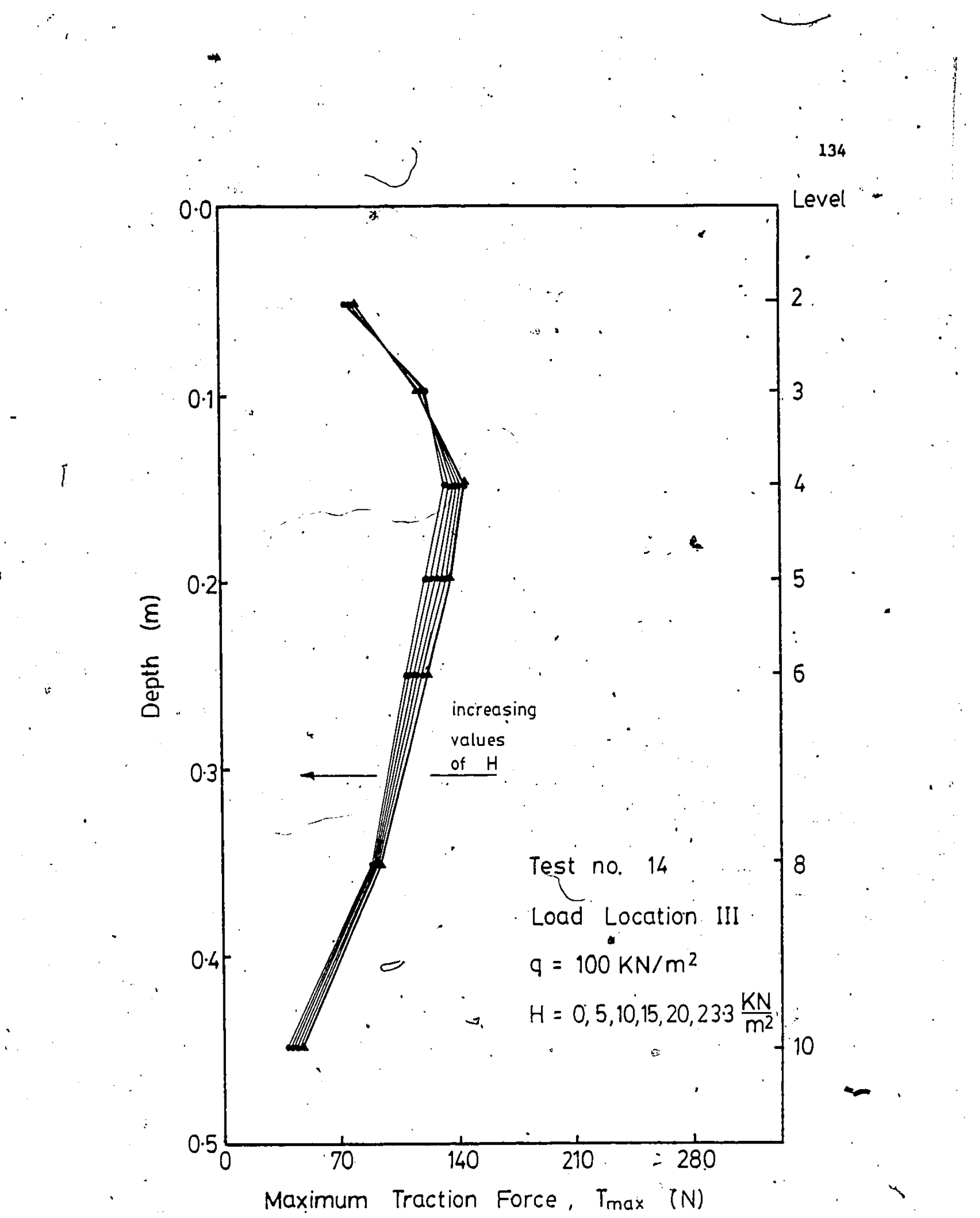

F1g. 4.51 Effect of Horizontal Component ondstribution of Maximum Traction Force with Depth. 


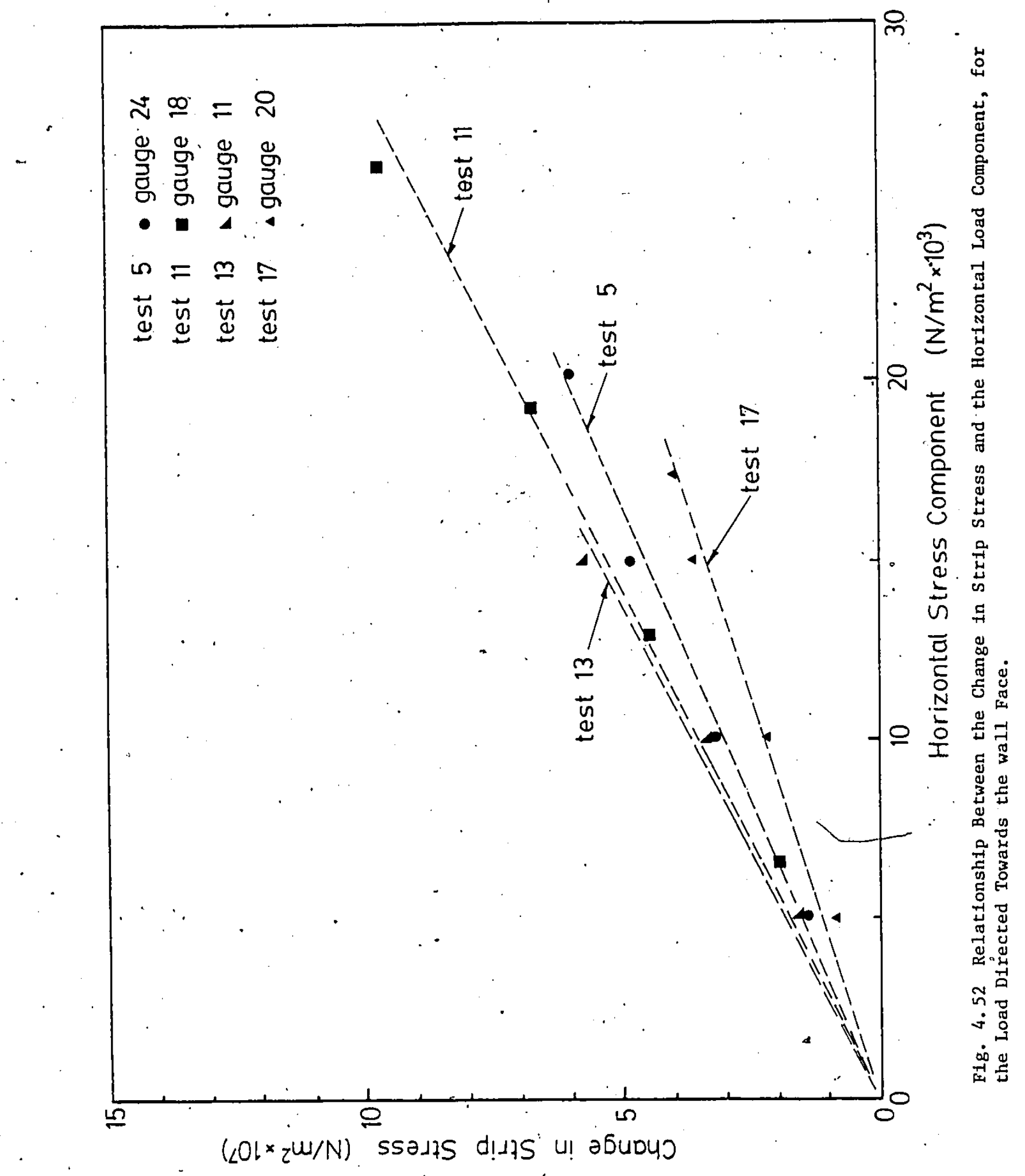




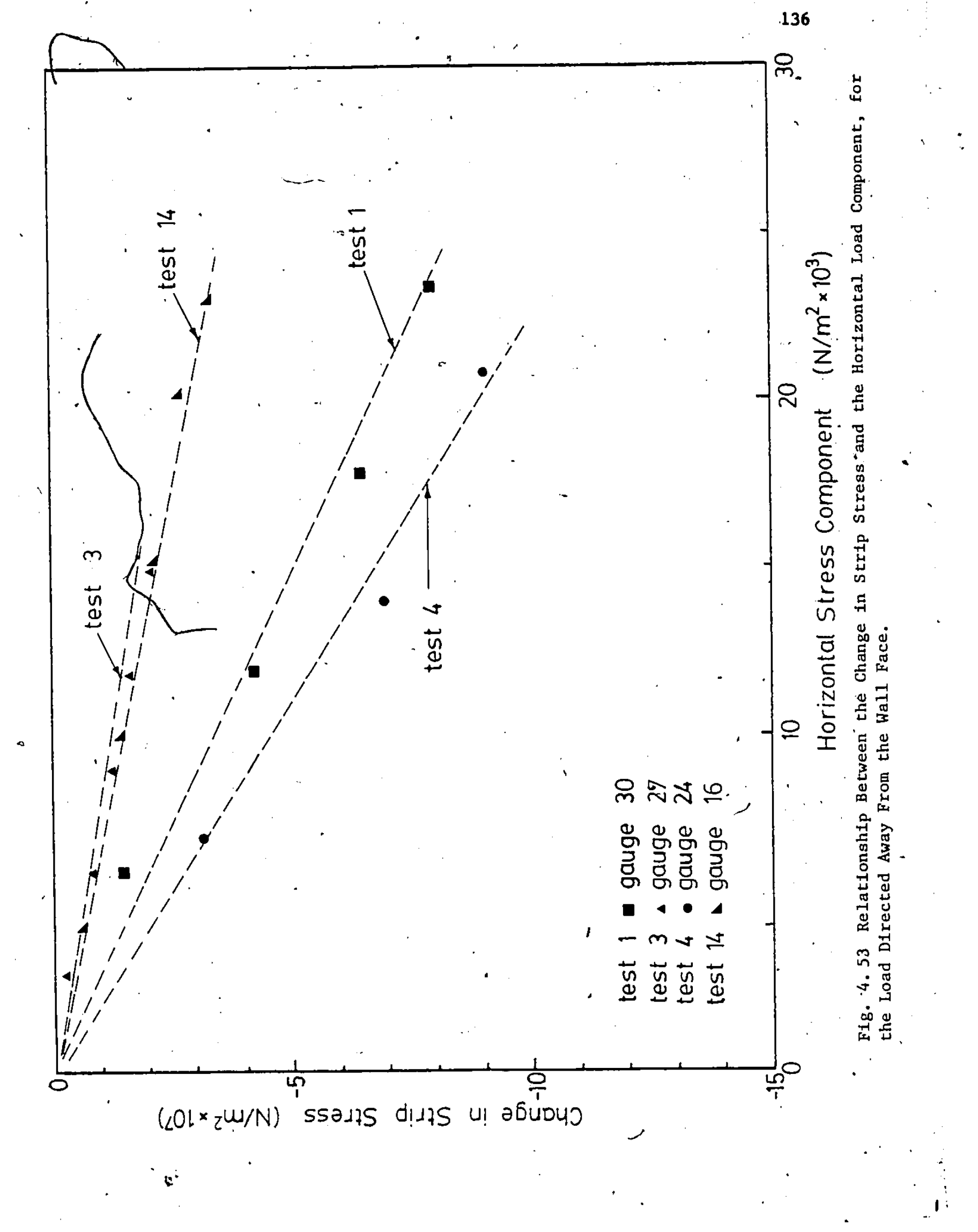




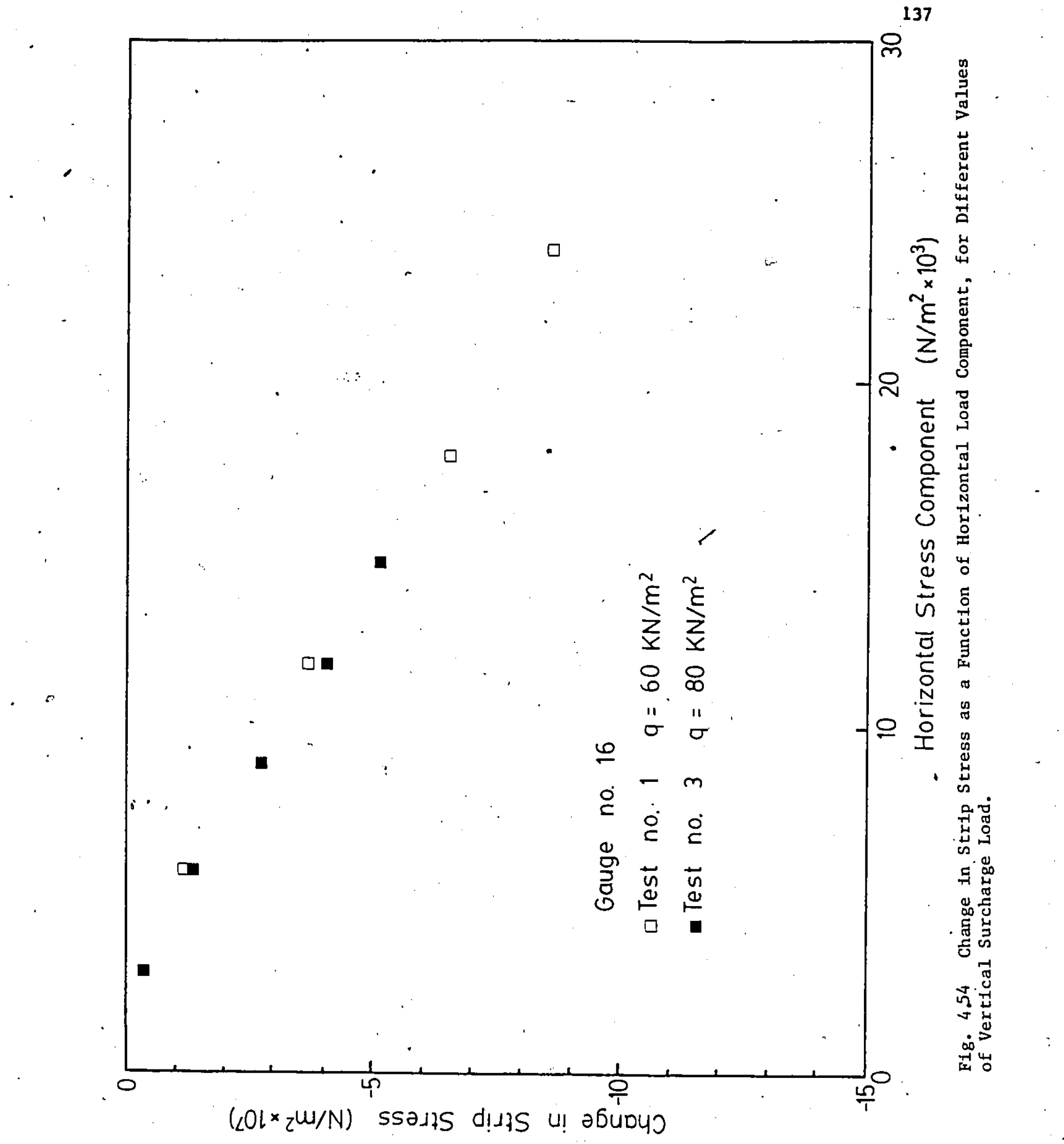




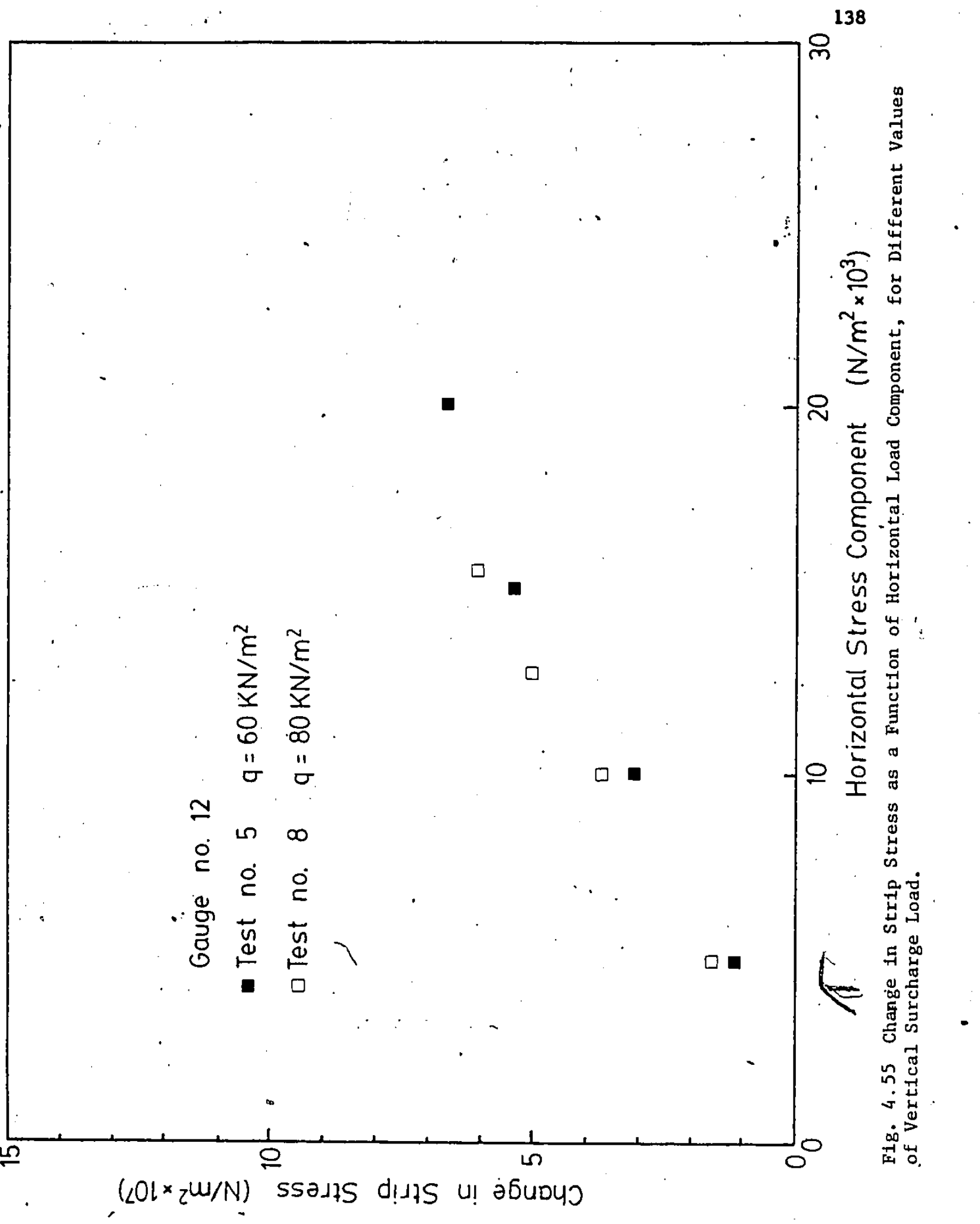




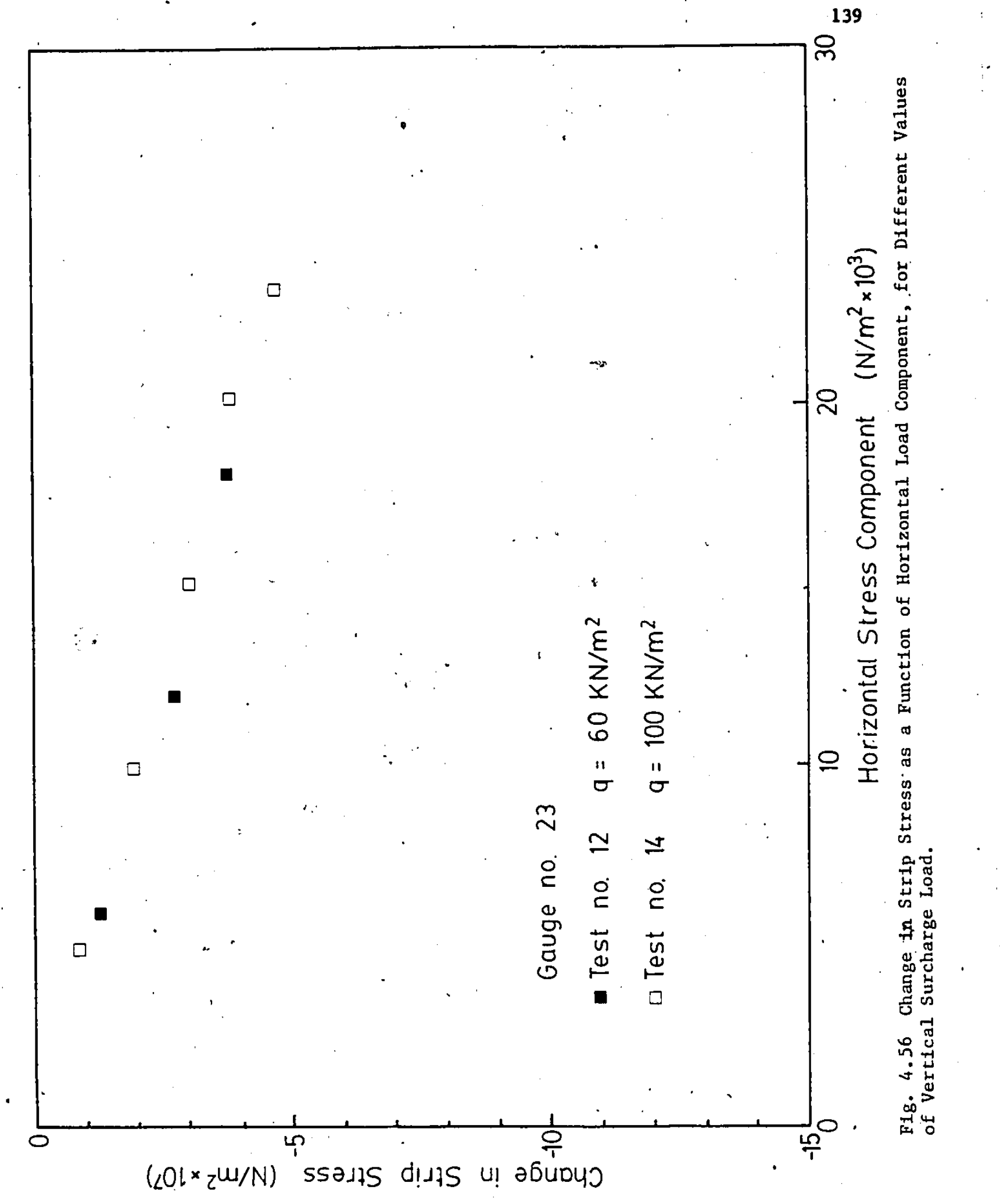




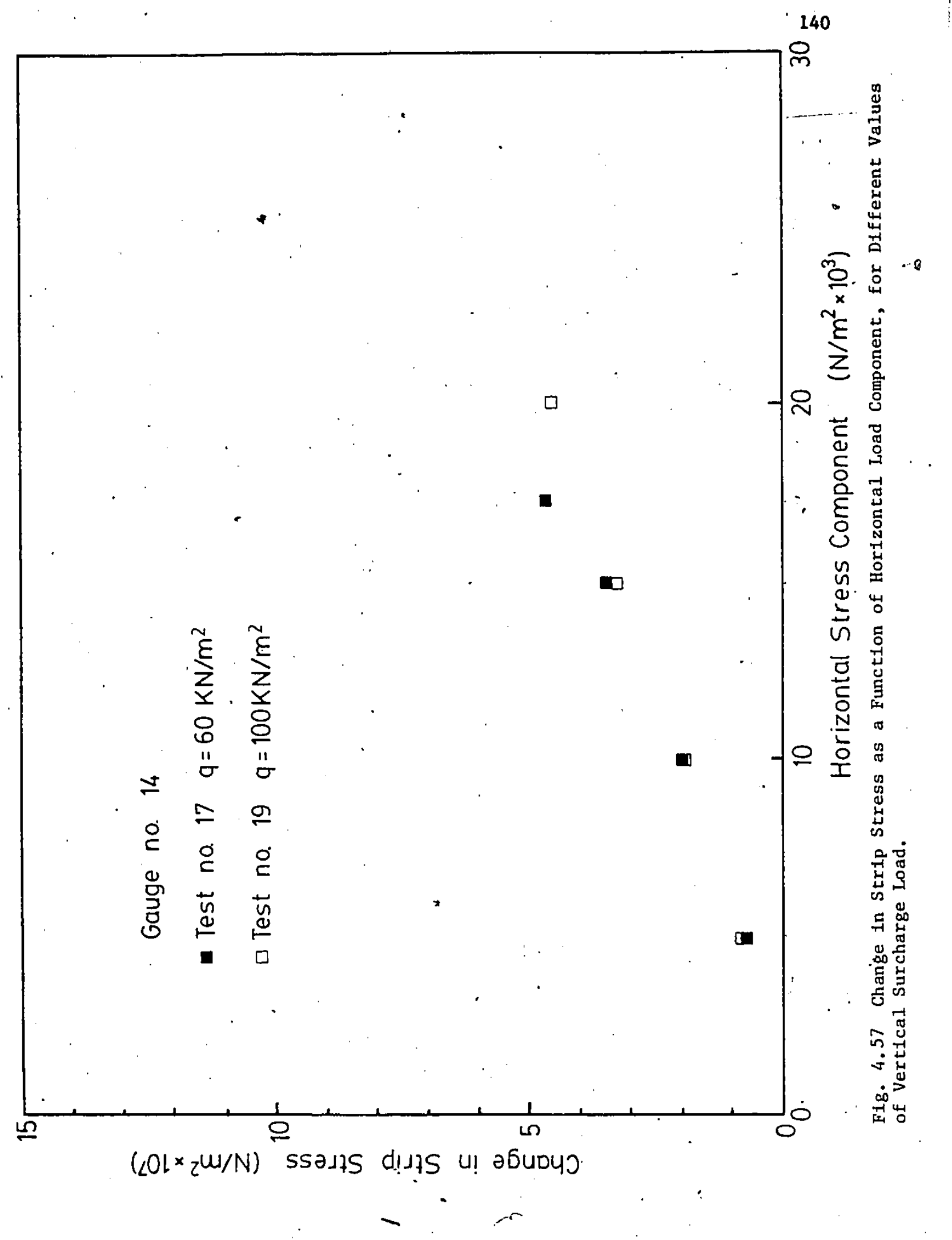




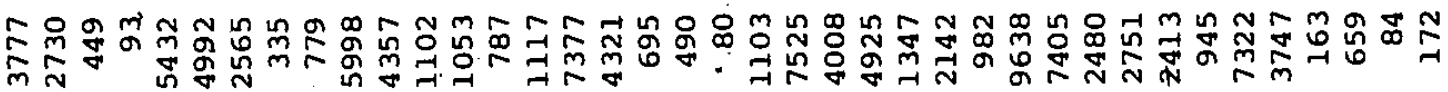

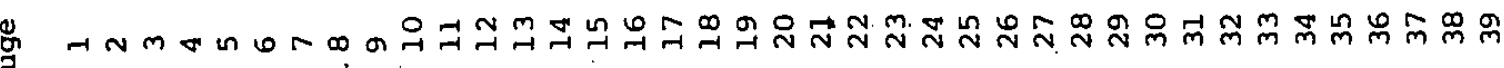

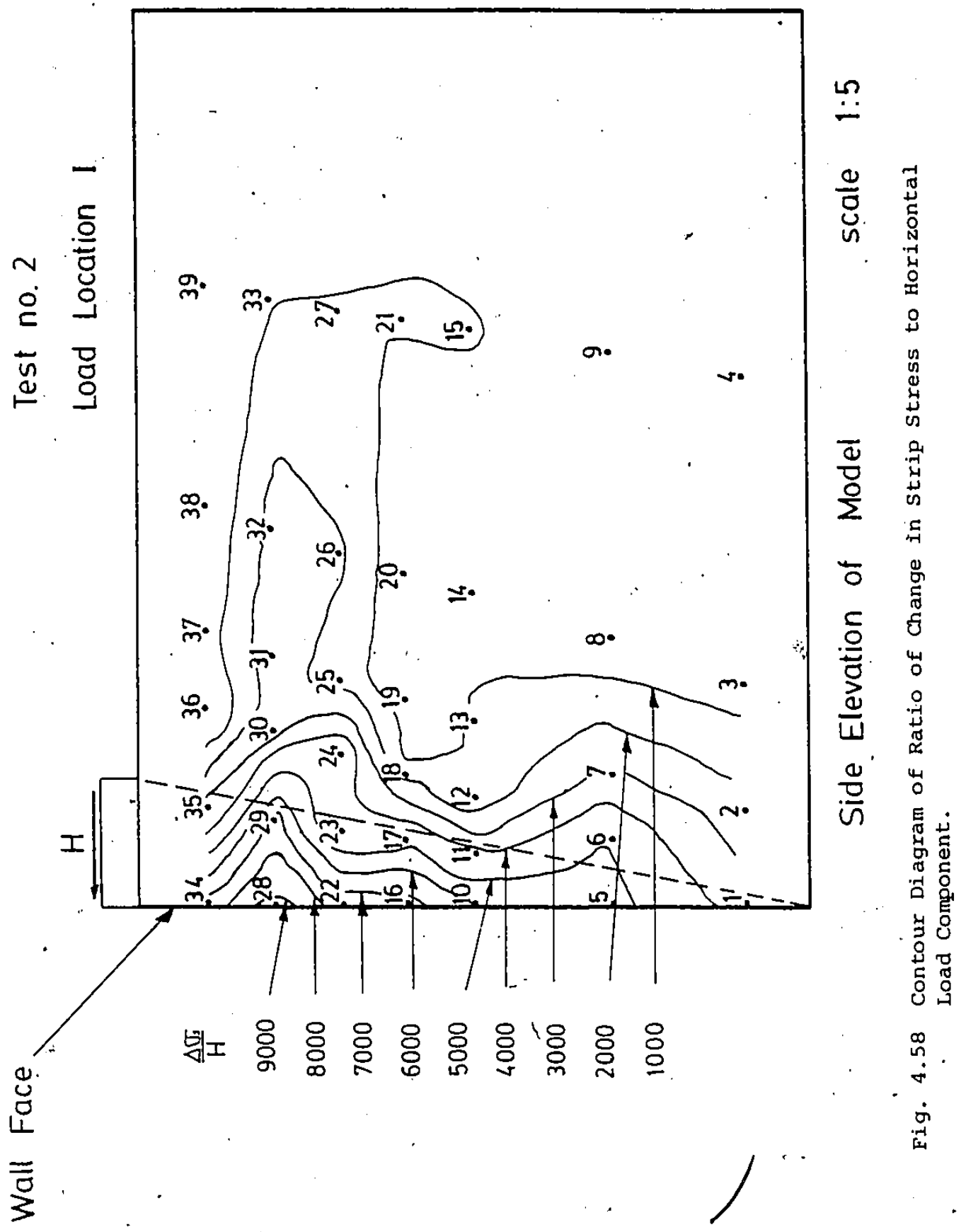




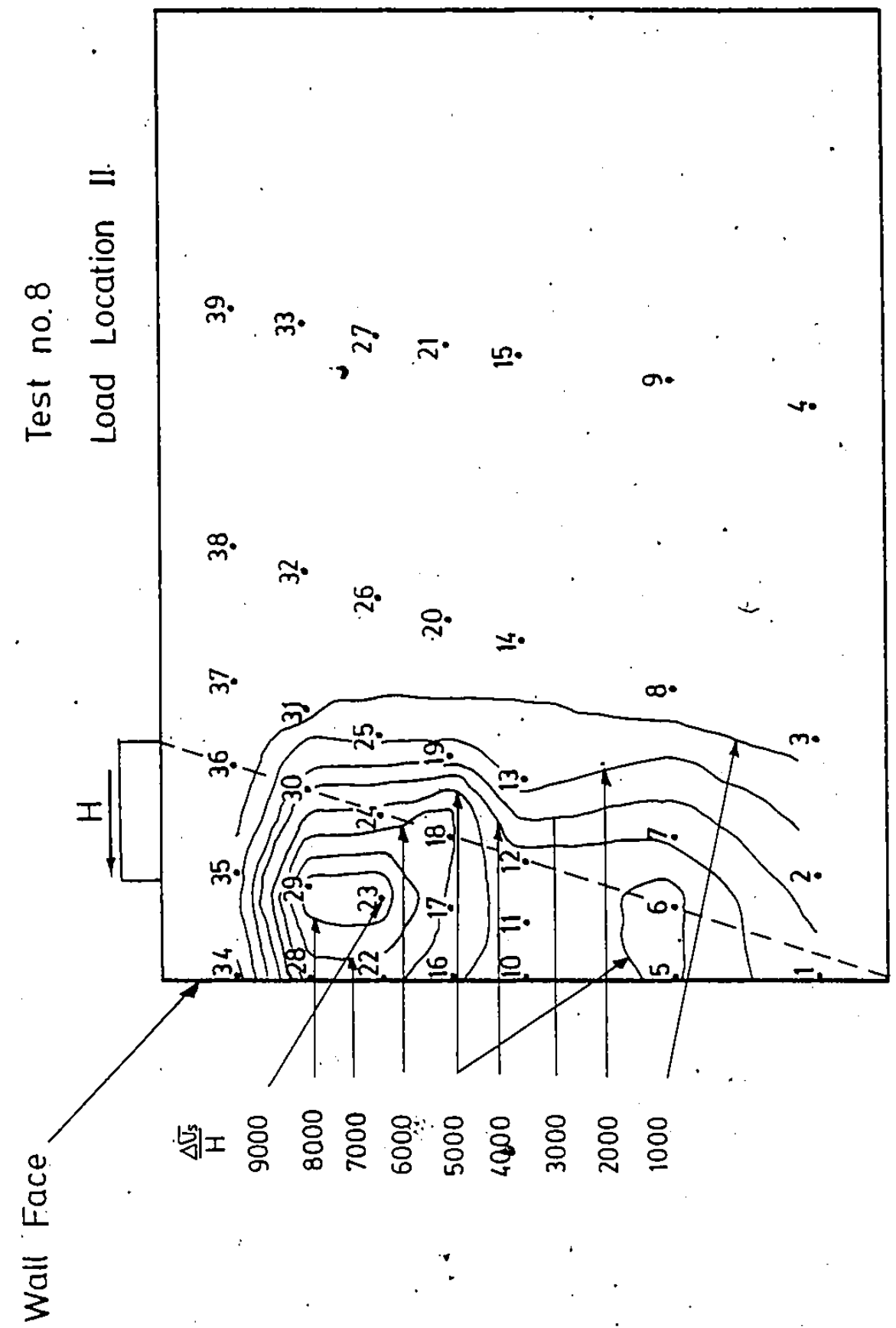

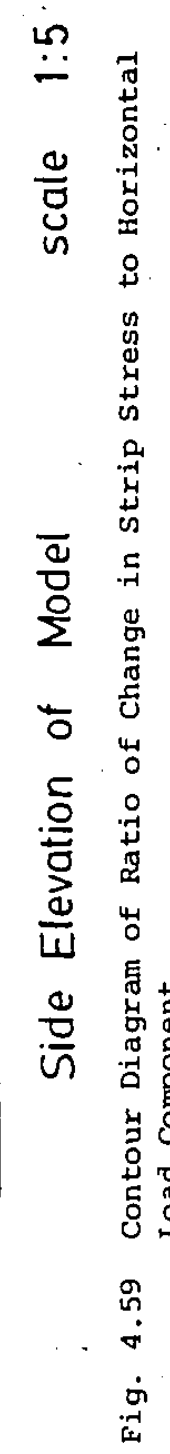




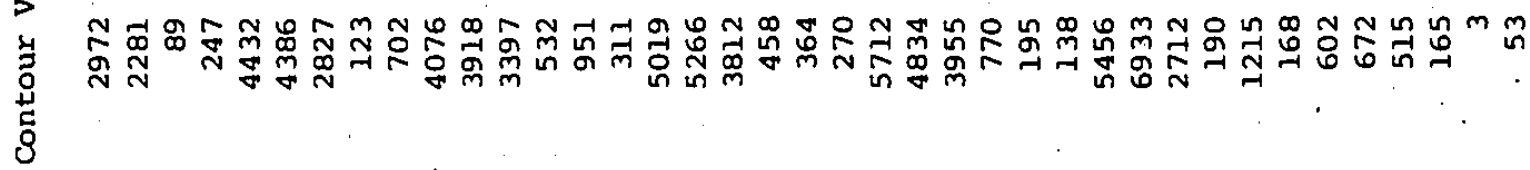

$\dot{q}$.

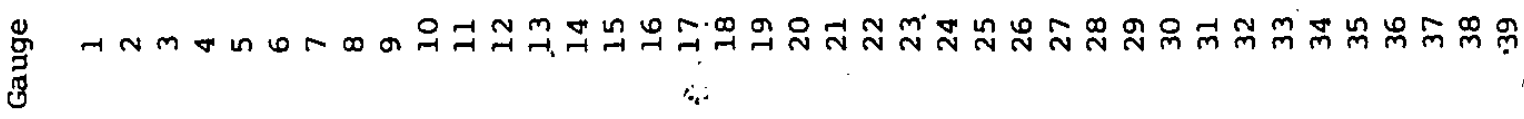

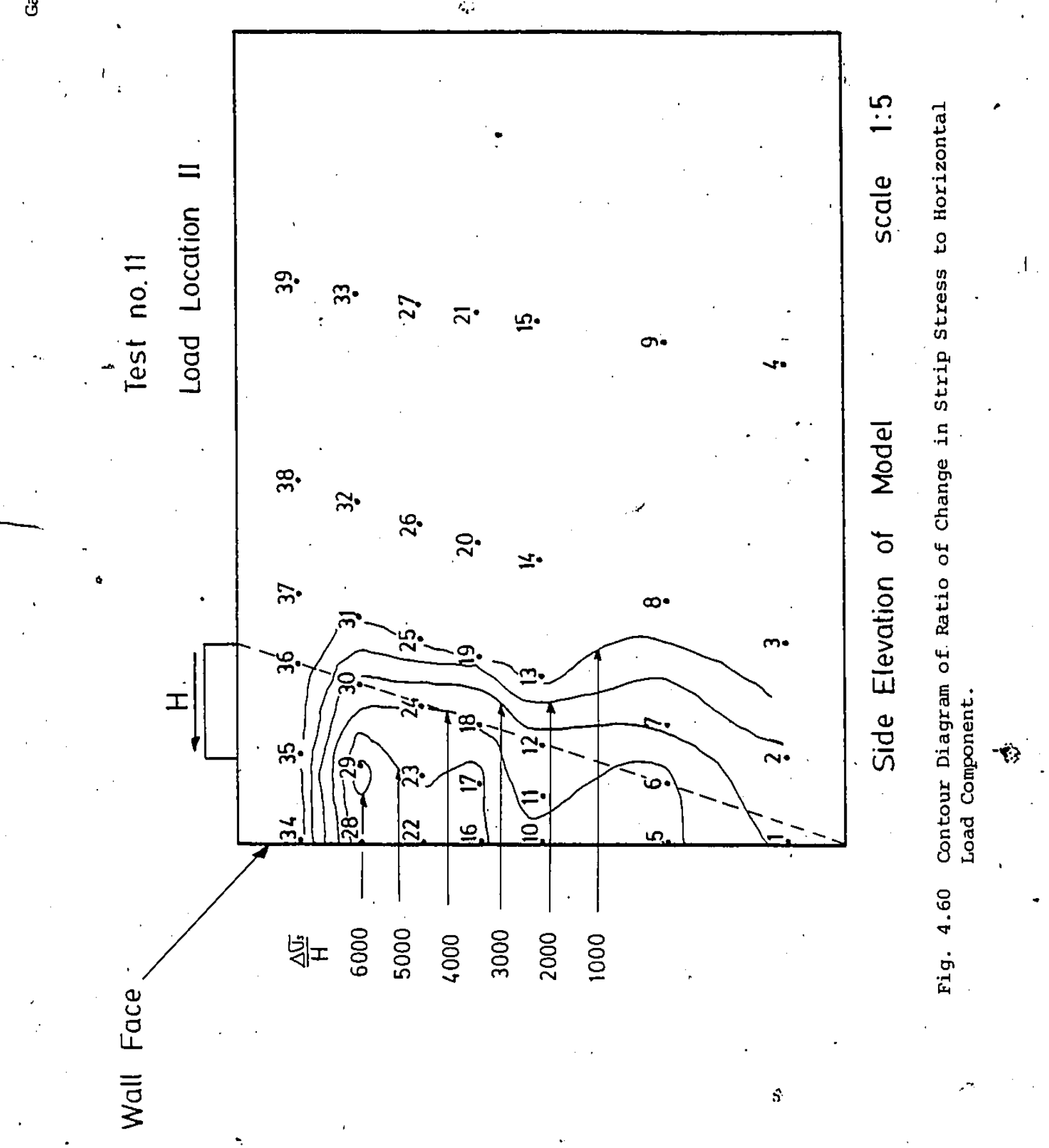




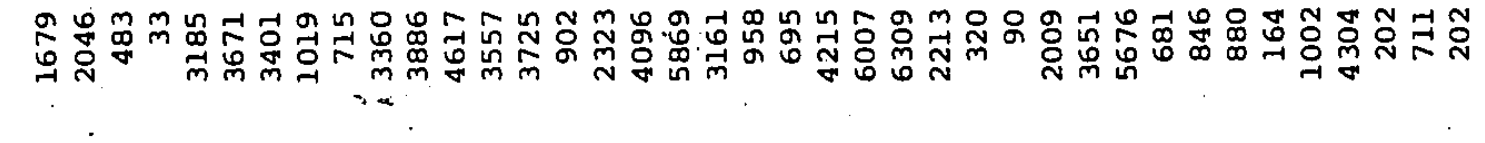

$\dot{0}$

兽 † N

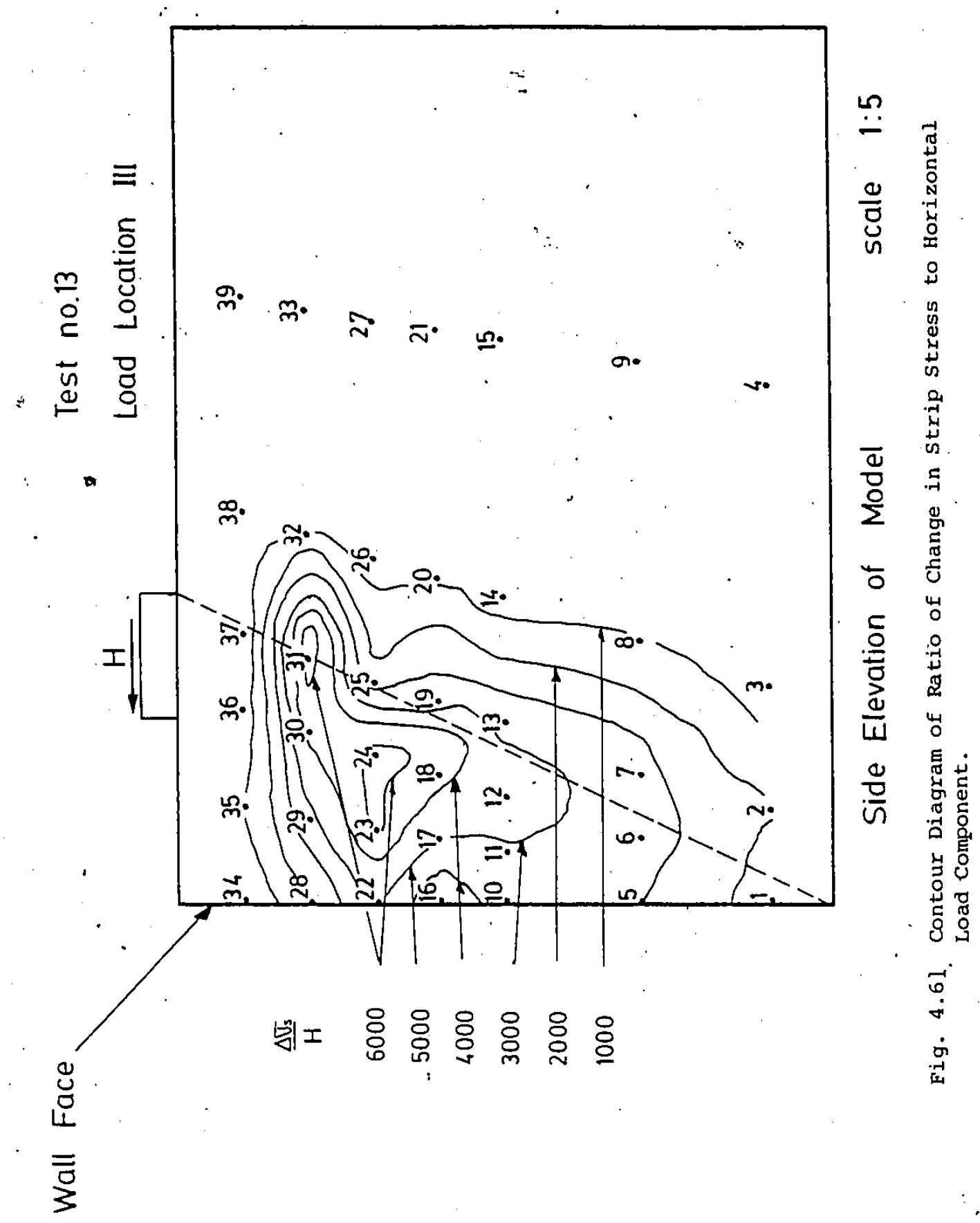




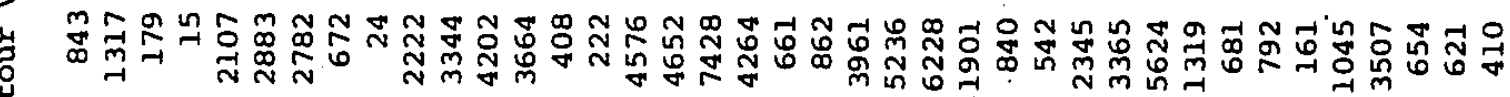

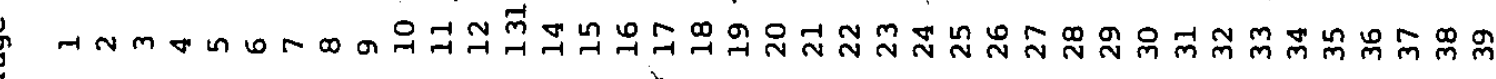
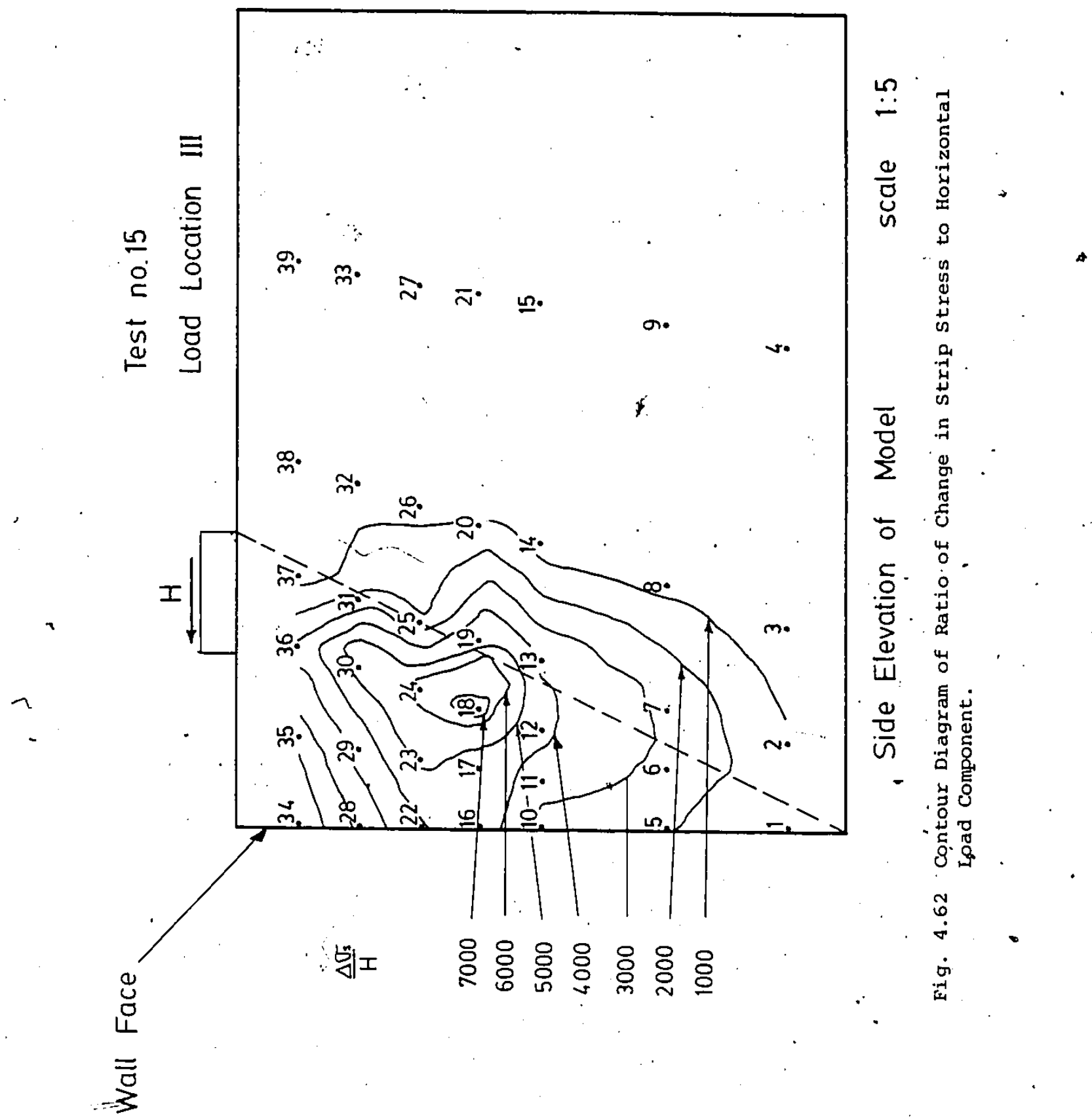

듬

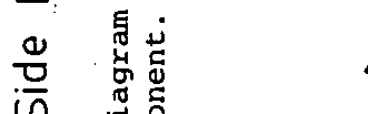




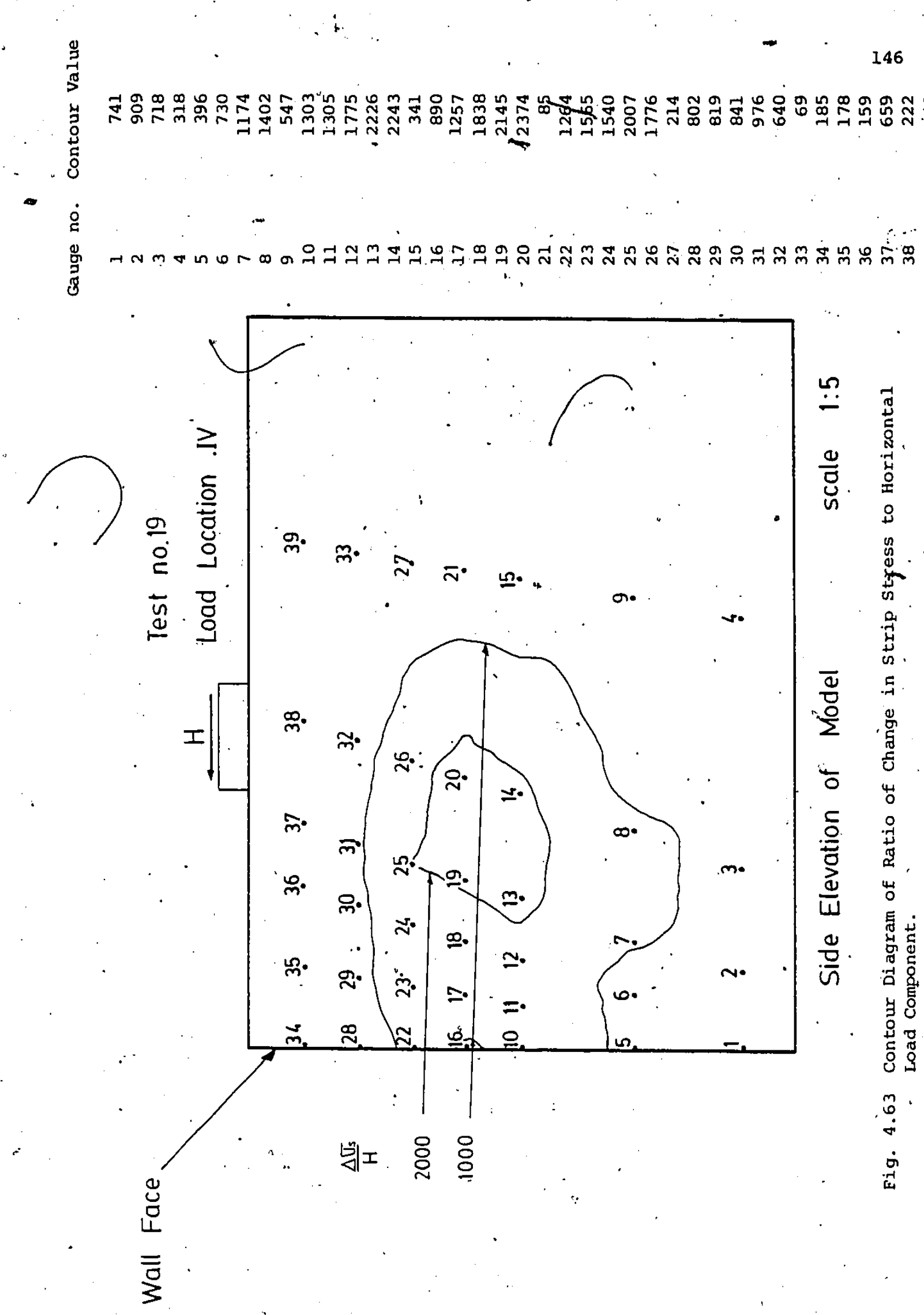




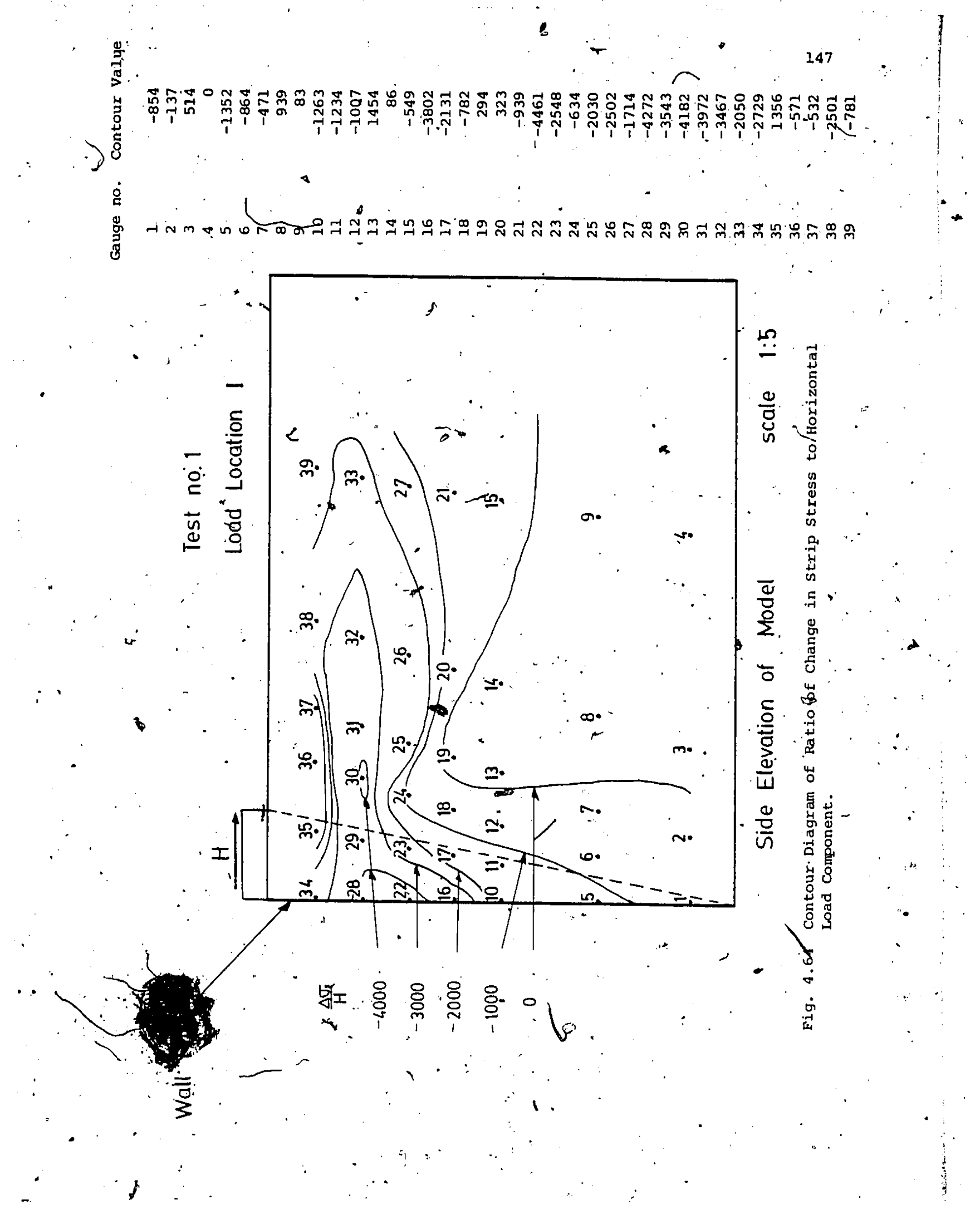




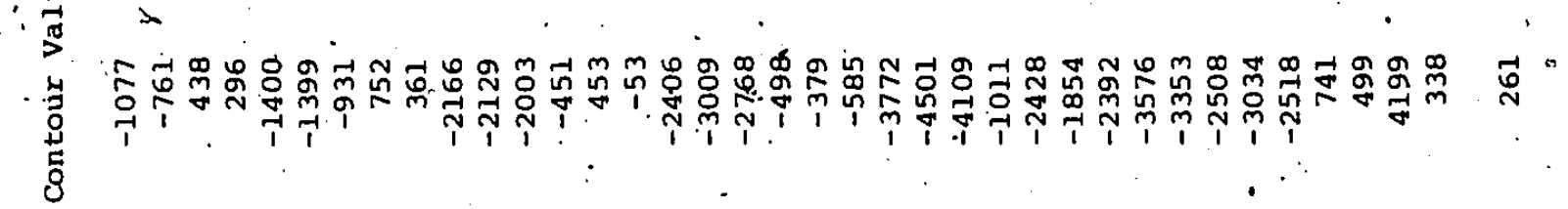

$\dot{8}$

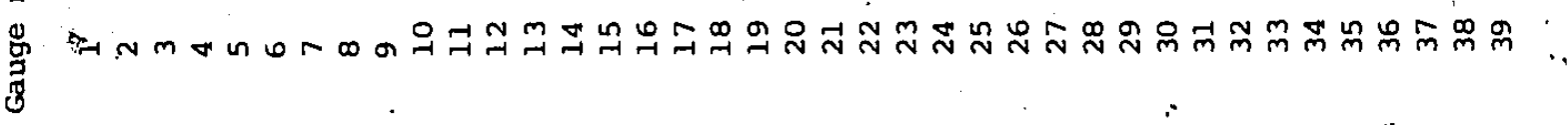

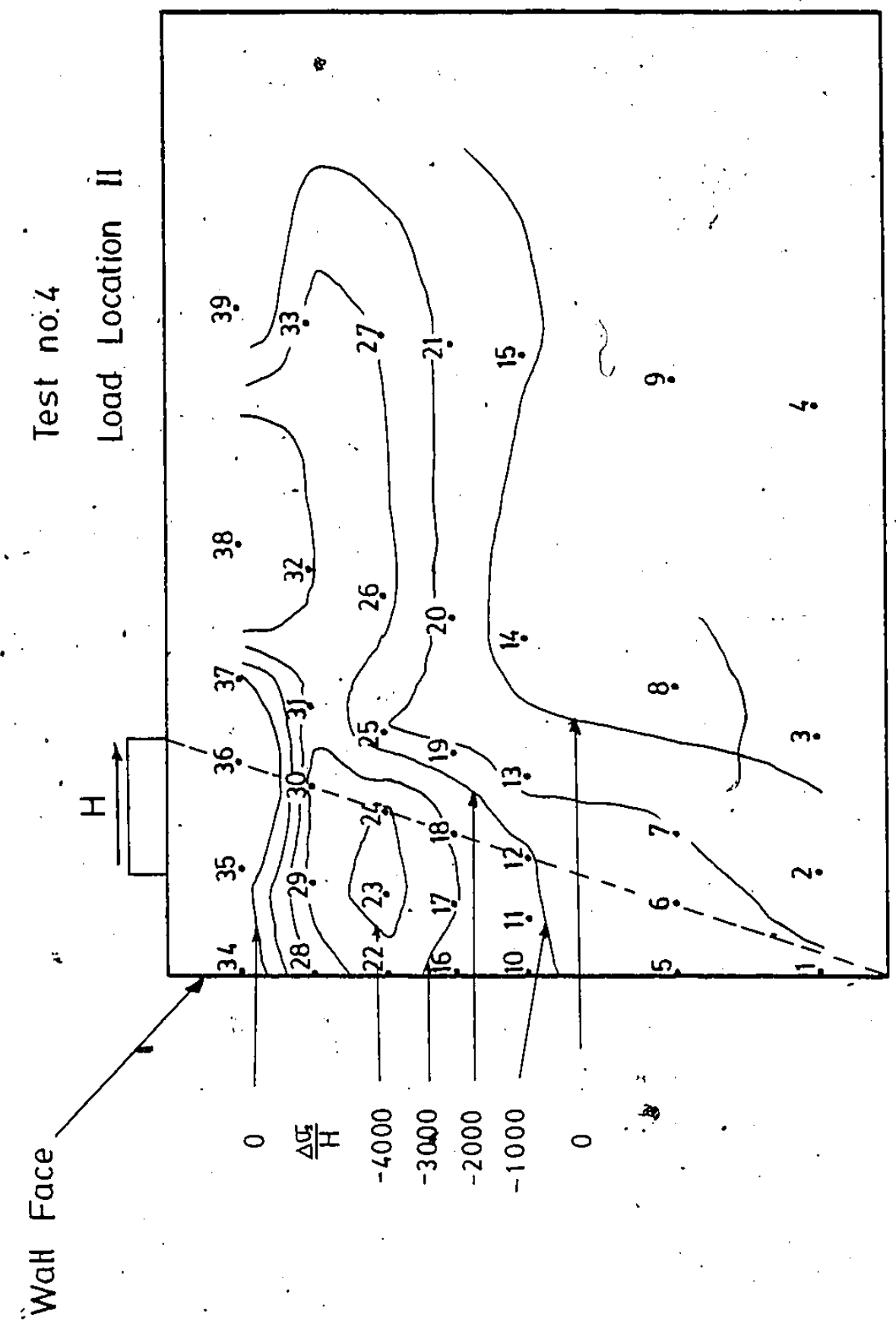

$\stackrel{5}{\square}$

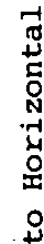

号.

.

-

$\therefore$

.

-

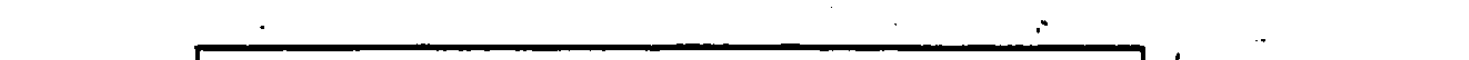



ఫ

急 - $\sim m$ m

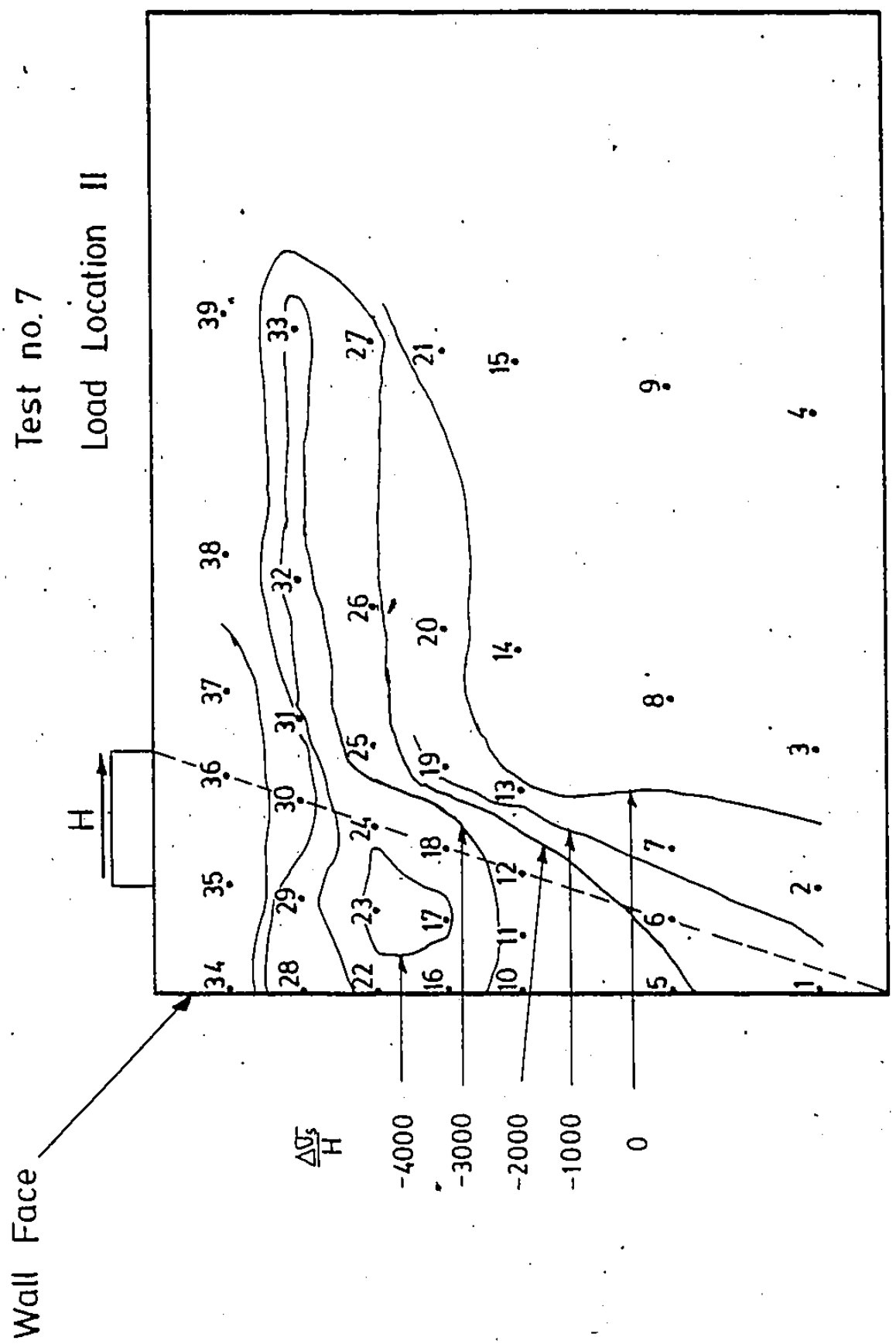

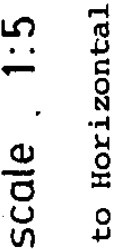

in

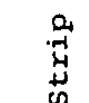

๘..

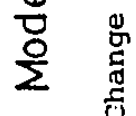

항

응 공 $\sum_{0}$

Ш山

记 离

in

马

80

ஜํ.

它 


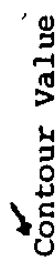

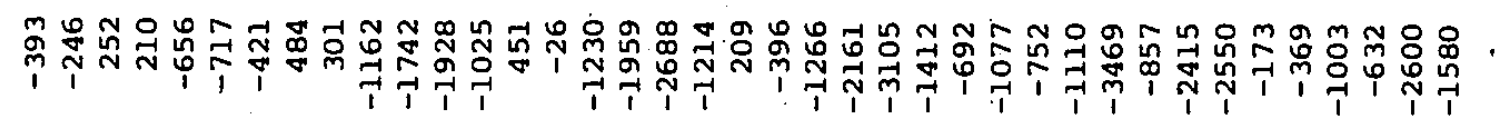

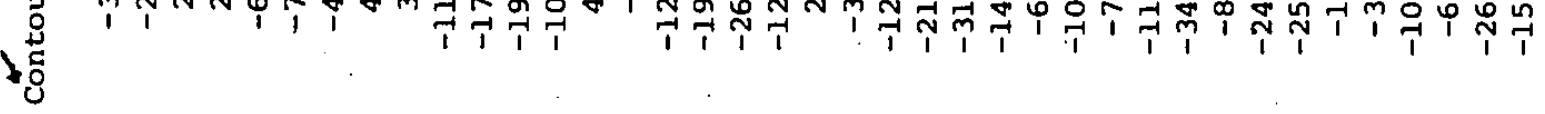

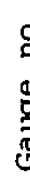

-Nm

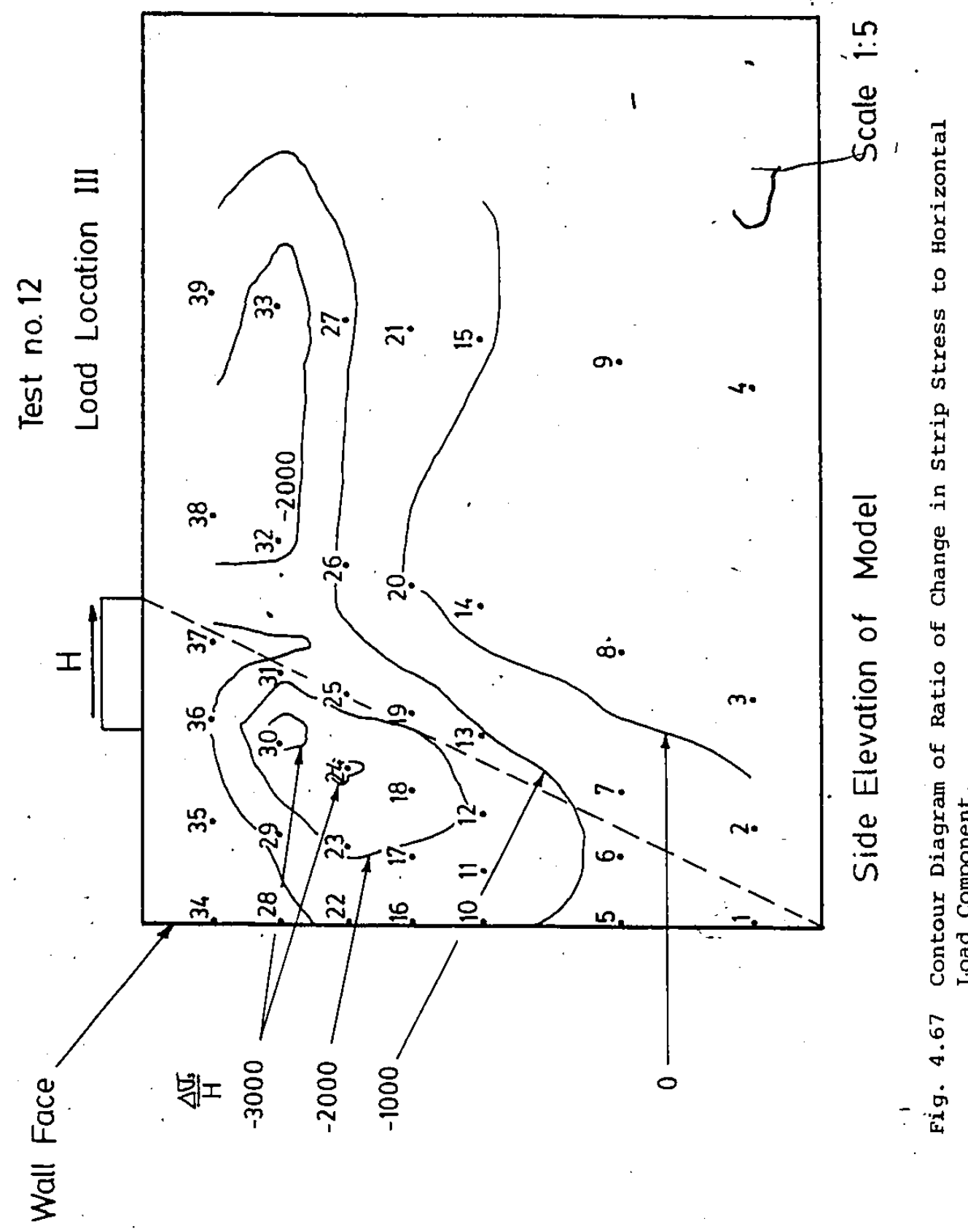




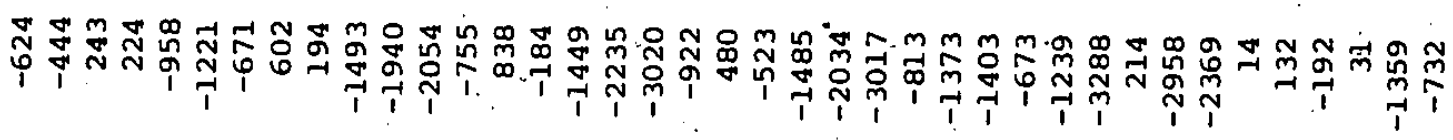

$\dot{8}$

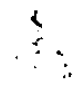

灵

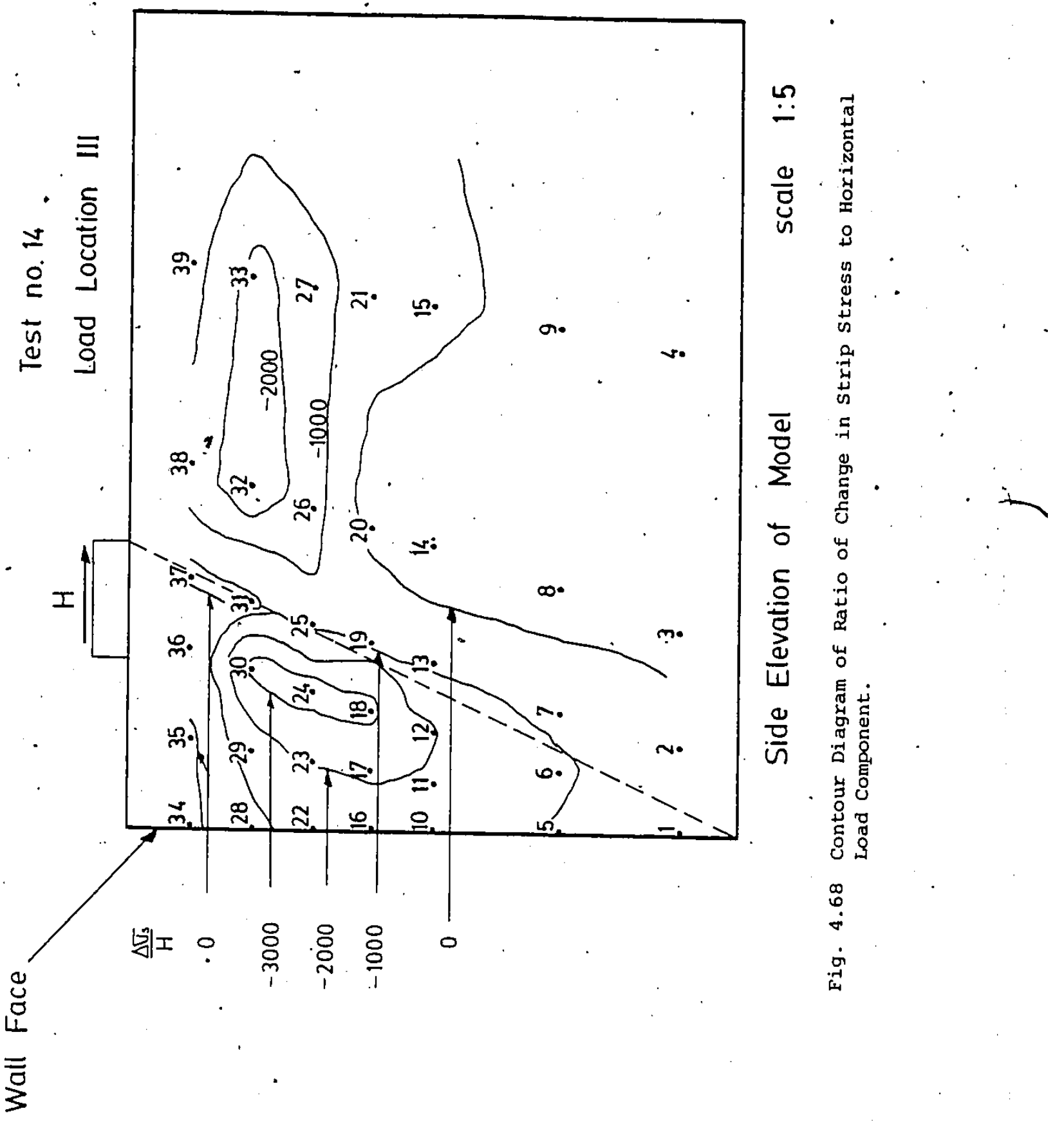




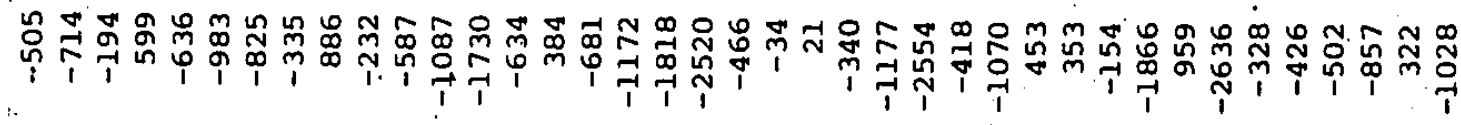

용

若
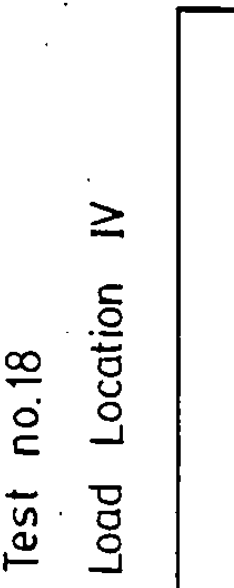

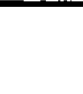

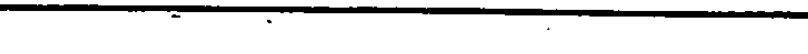

$$
I
$$
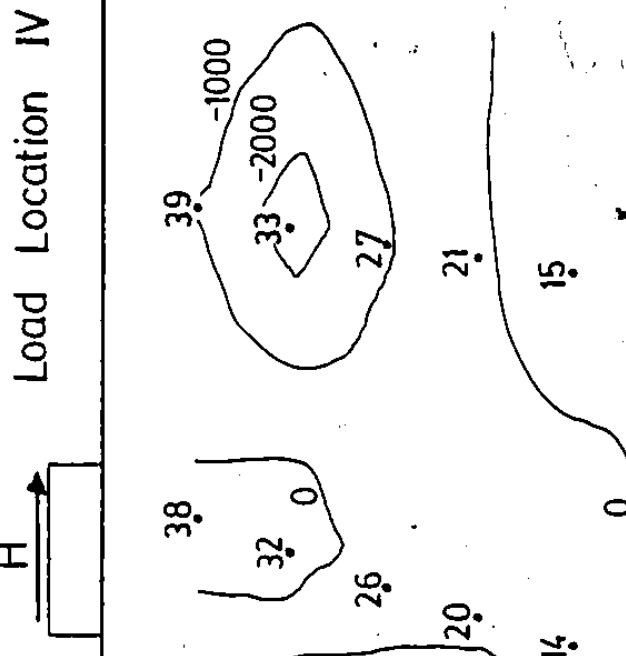


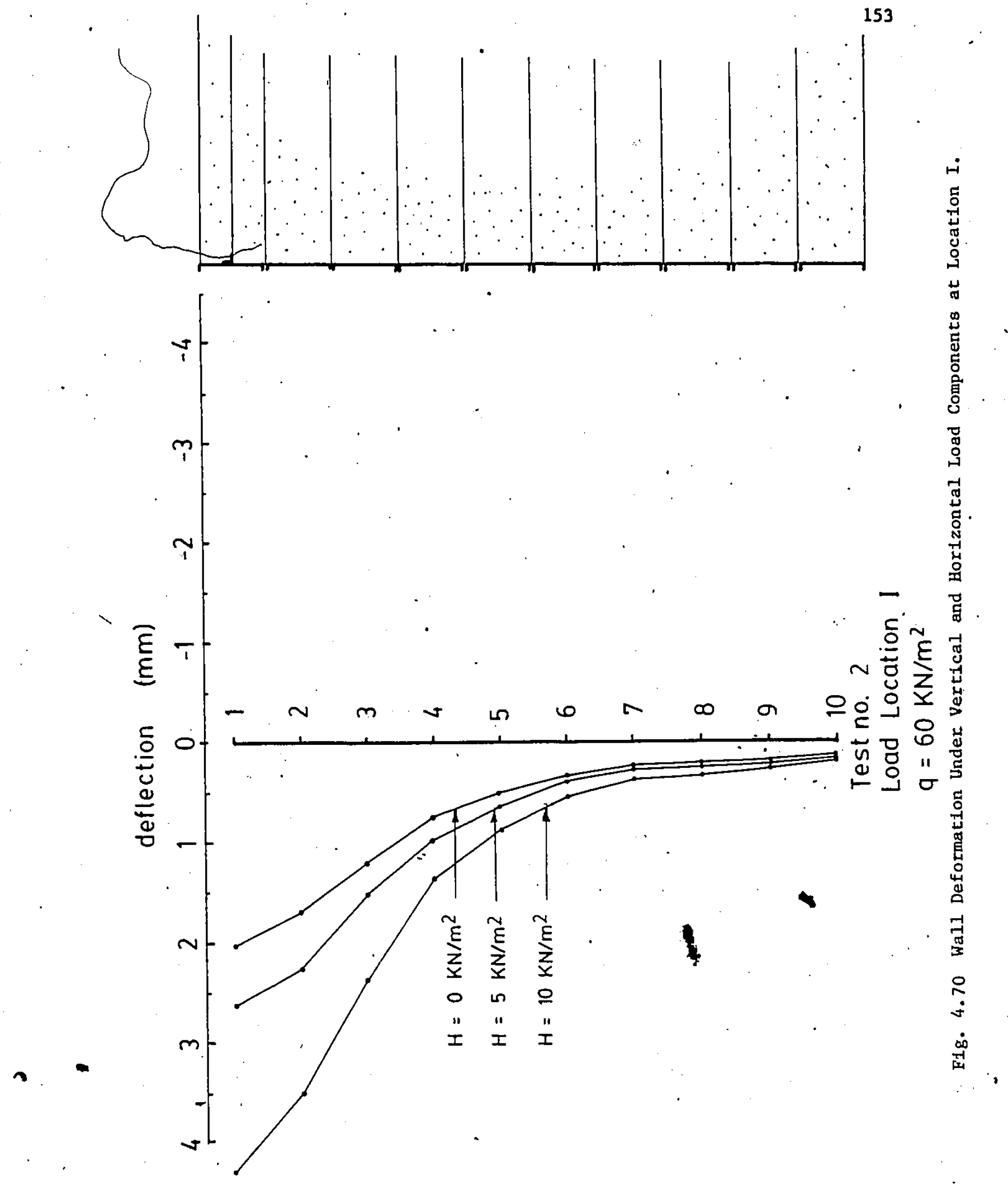




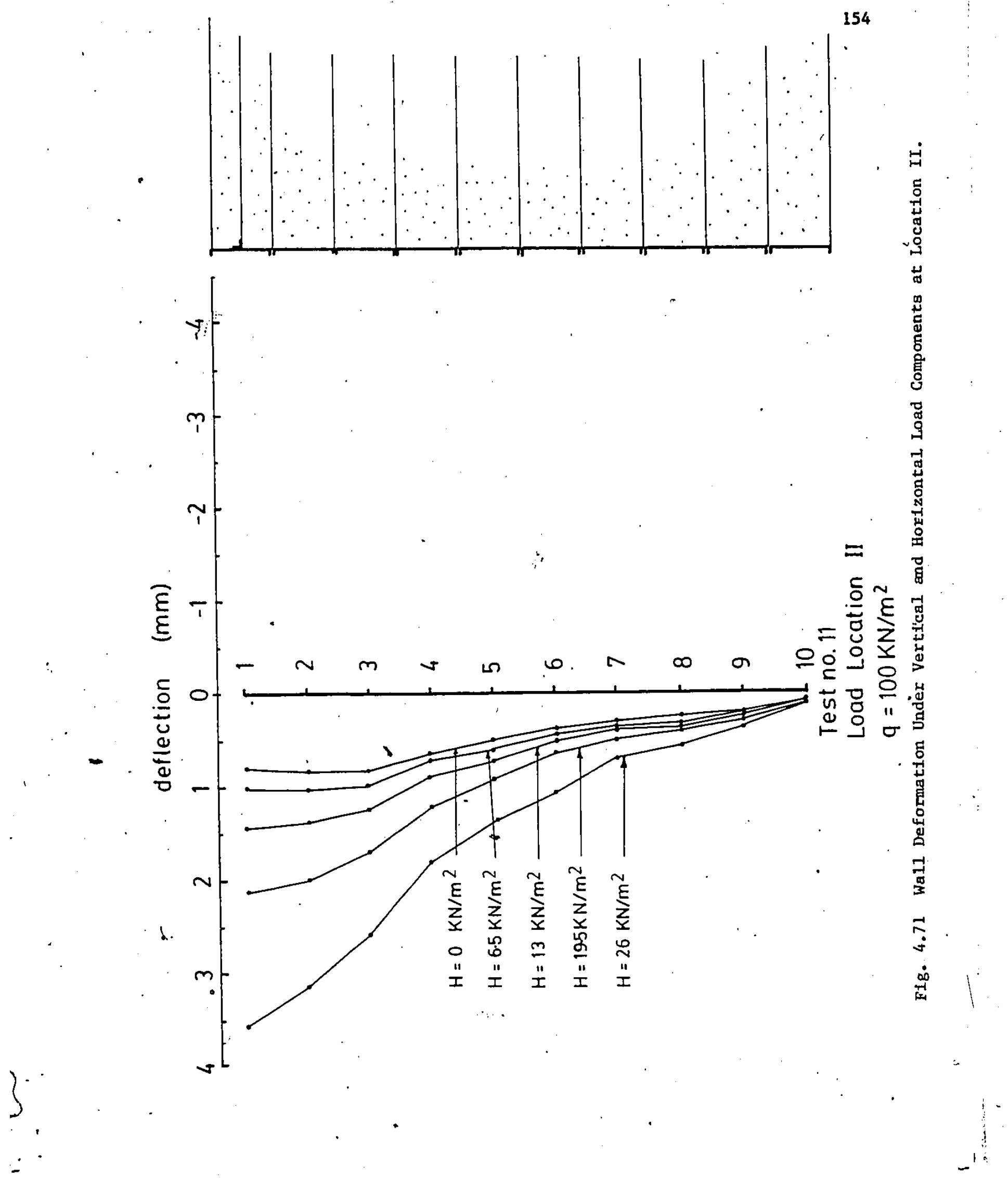




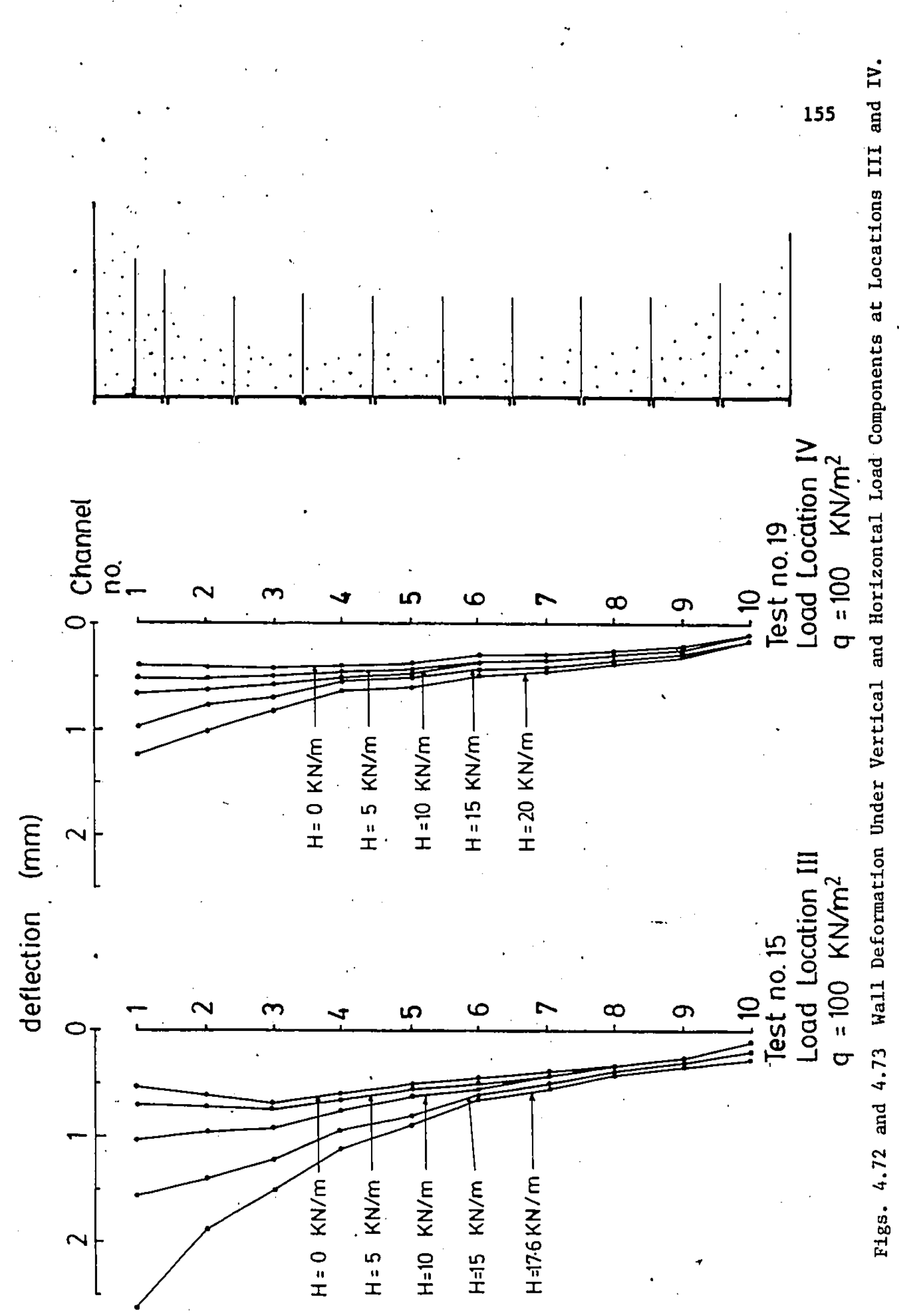




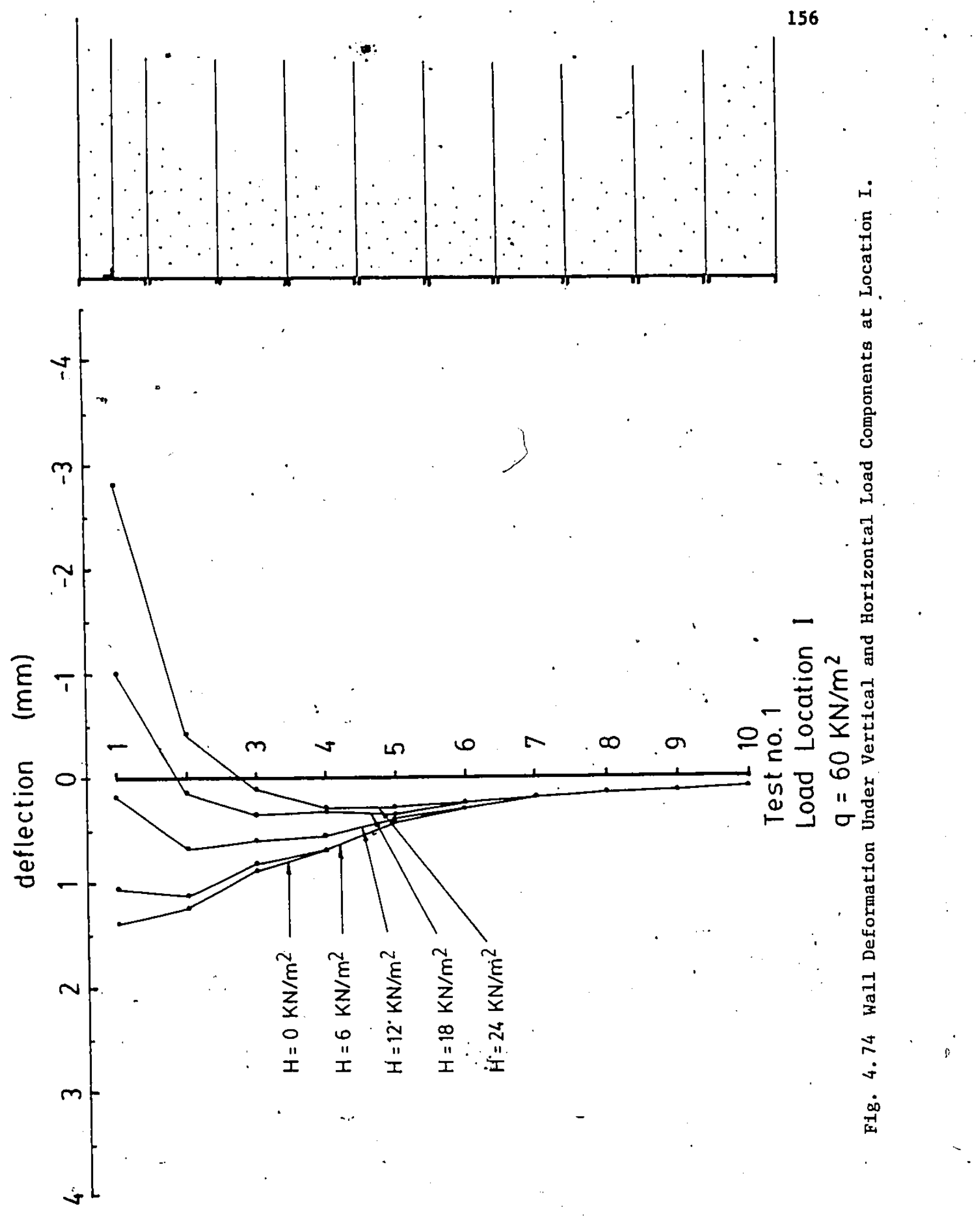




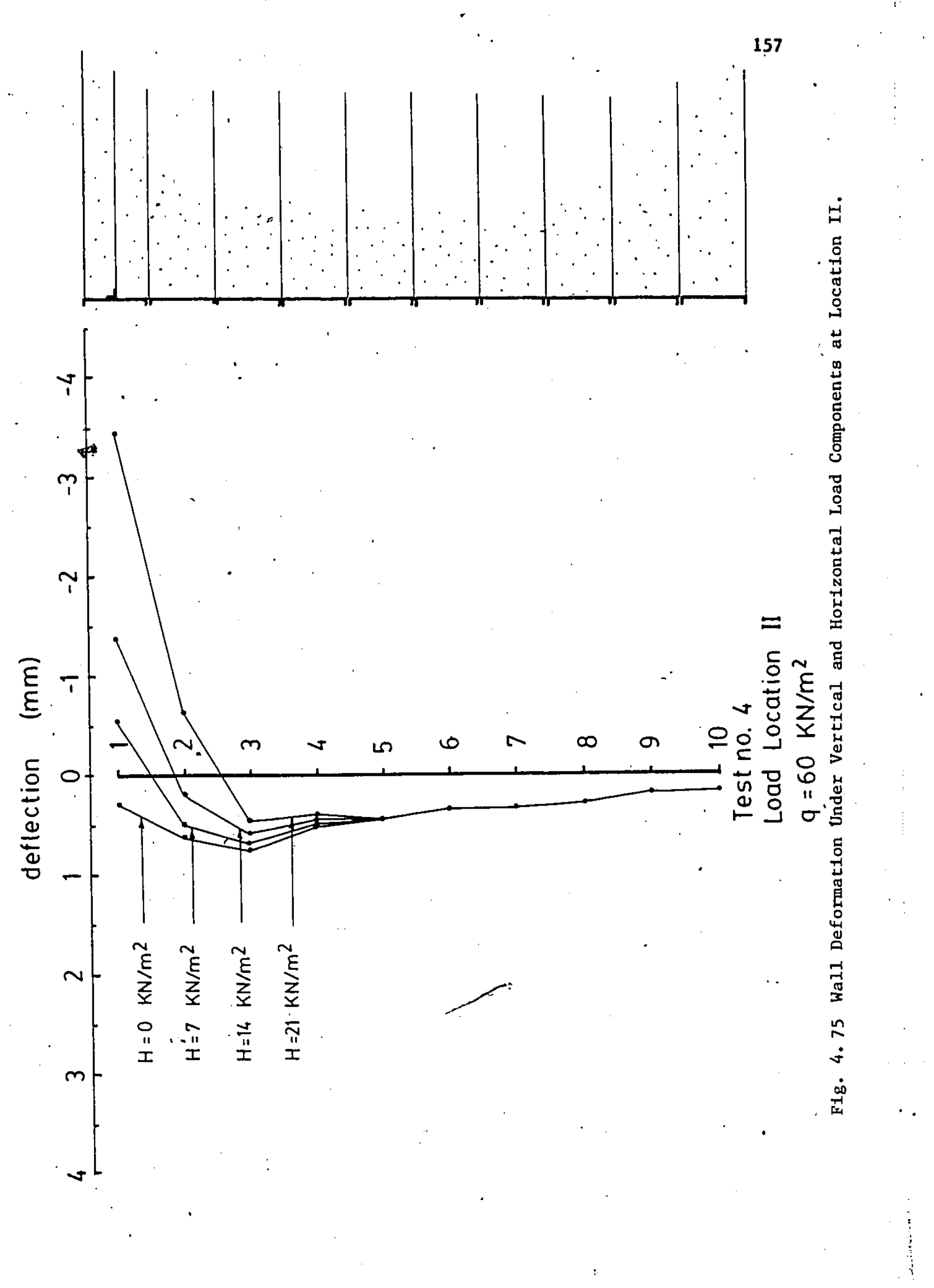




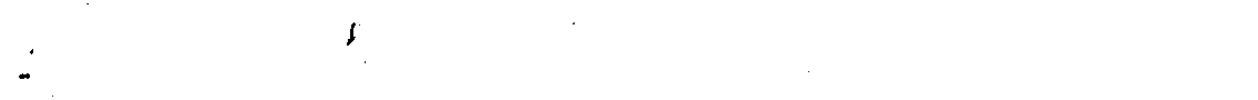

\section{Active Zone}

$\because$

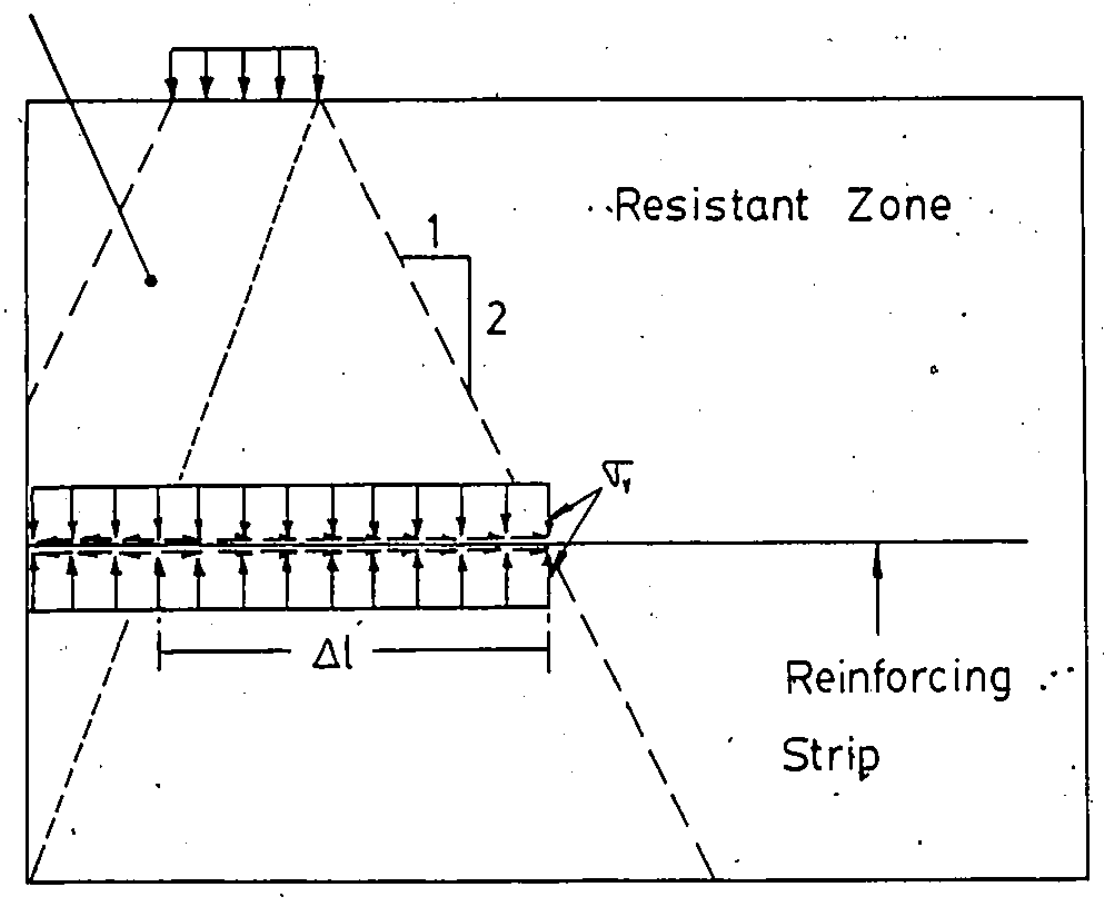

Fig. 5.1 Partition of the Active and Reslstant Zones, and the 2:1 Load Dispersion Configuration.

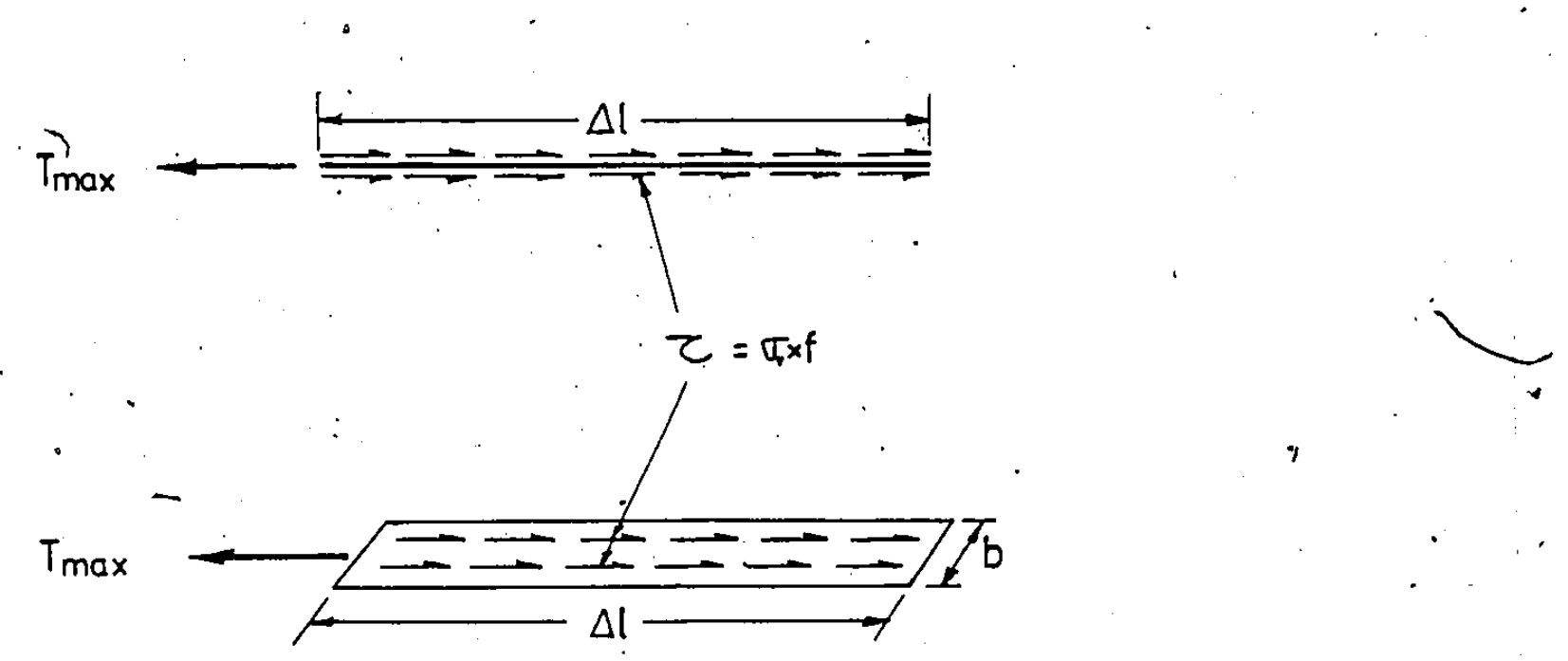

Fig. 5.2 Free-Body Diagram of Strip Portion. 
160

0

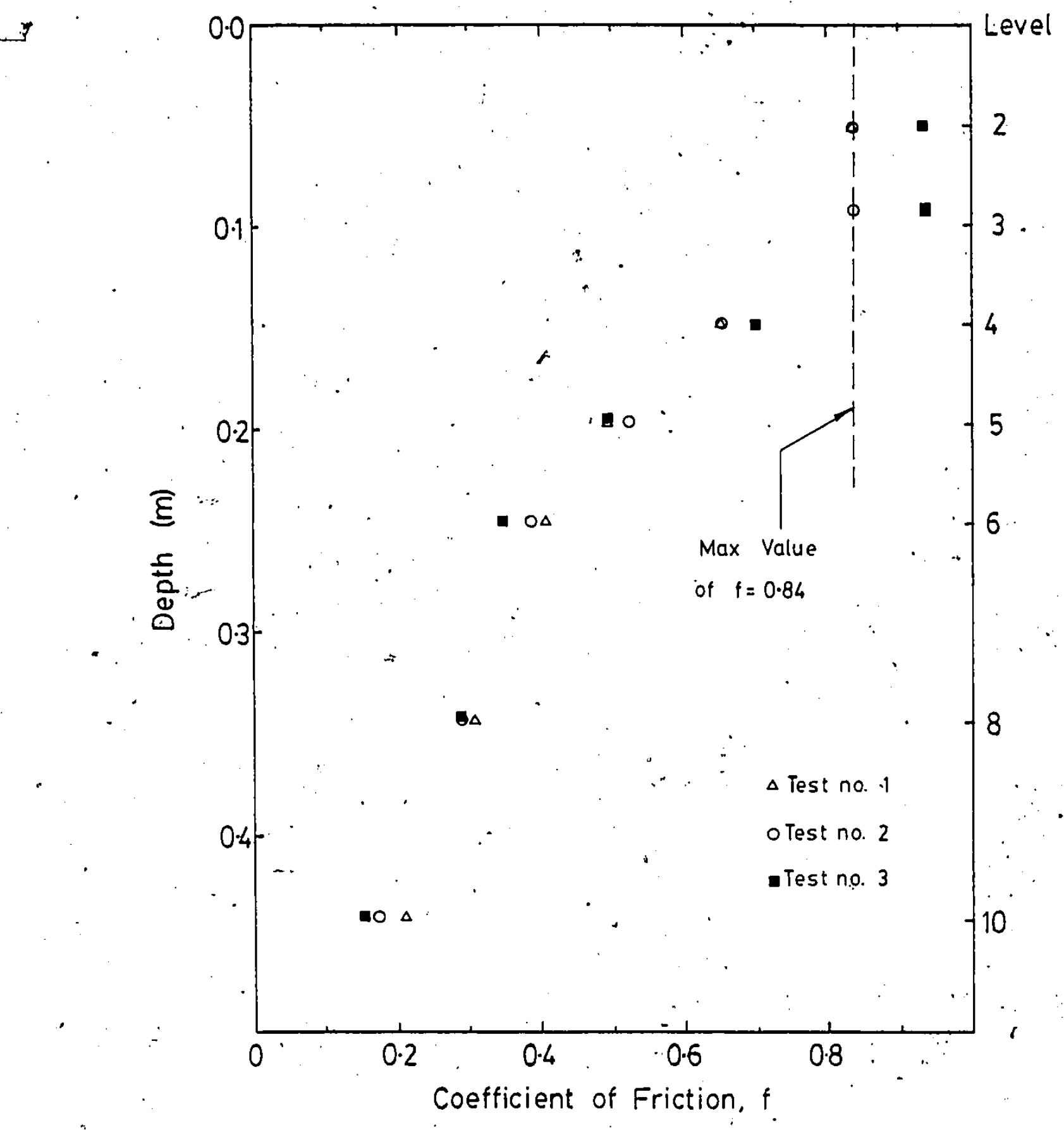

F1g. 5.3 Coeffictent of Mobllized Soil-Stfip Friction, as a Function of Depth: Load Location I. 


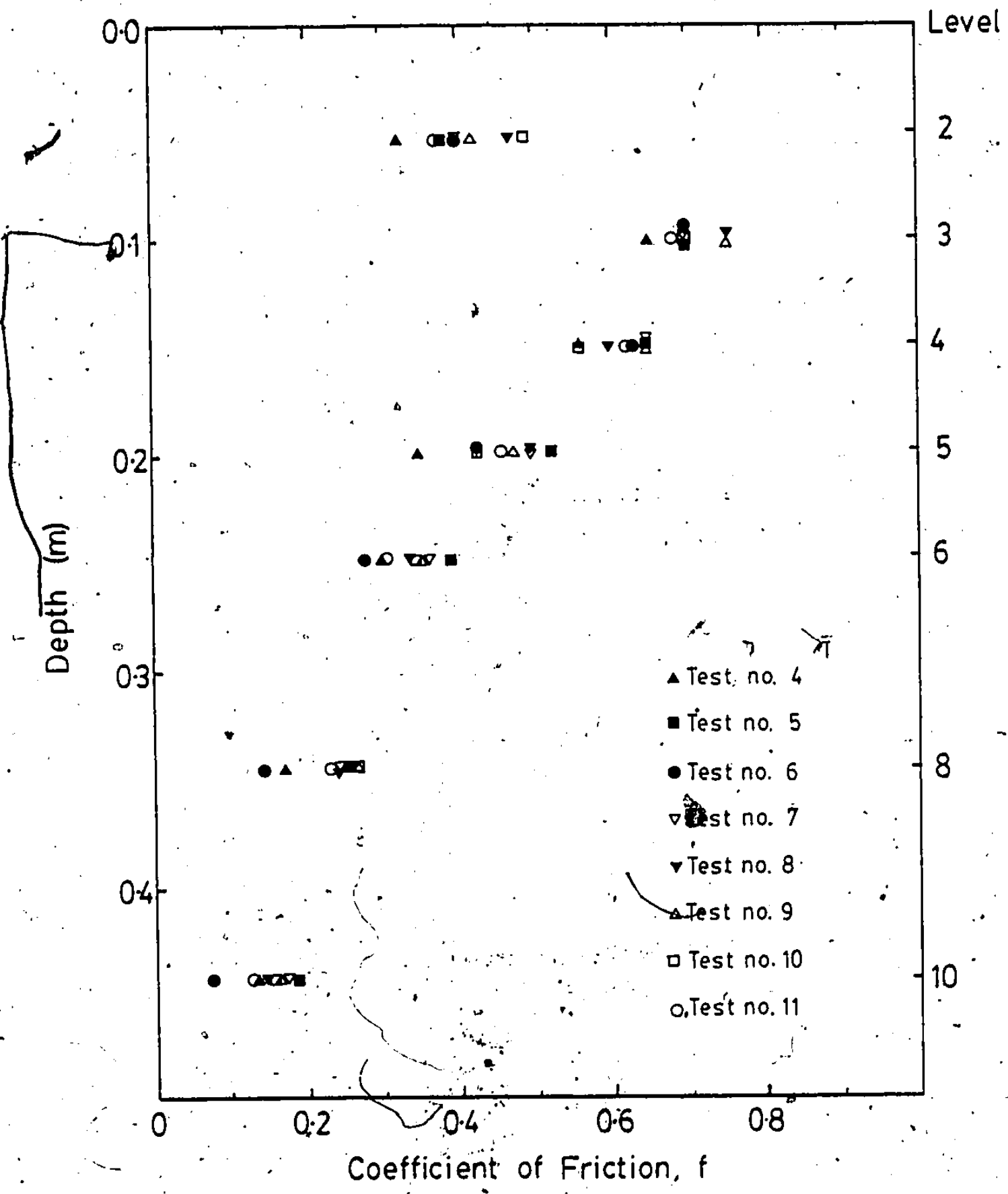

F1g. 5.4 Coefficient of Mobilized Soll-Strip Friction, as a Function of Depth : Load Location II. 


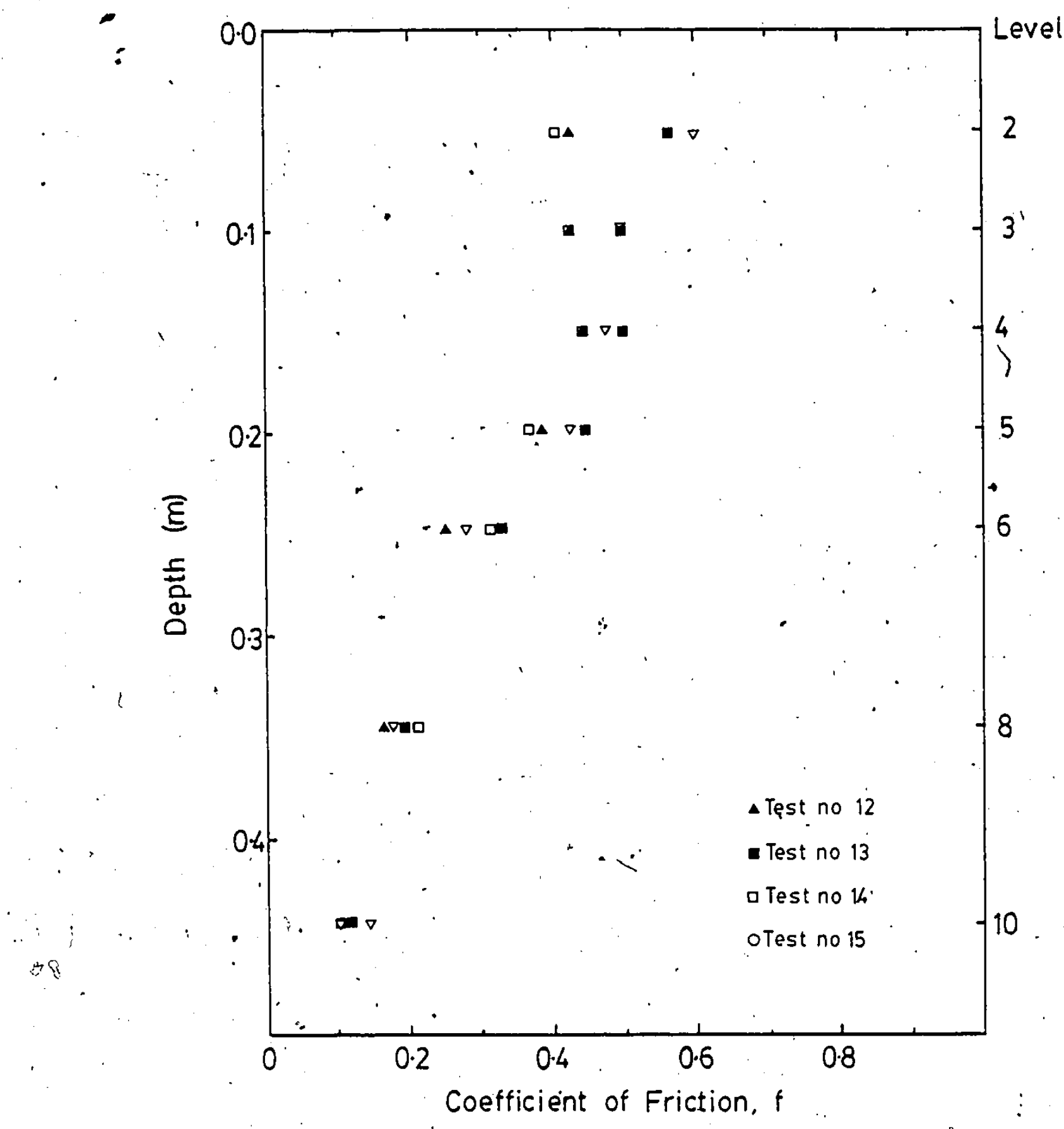

F1g. 5.5 Coeffictent of Mobilized Soll-Strtp Friction, as a Function of Depth: Load.Location III. 


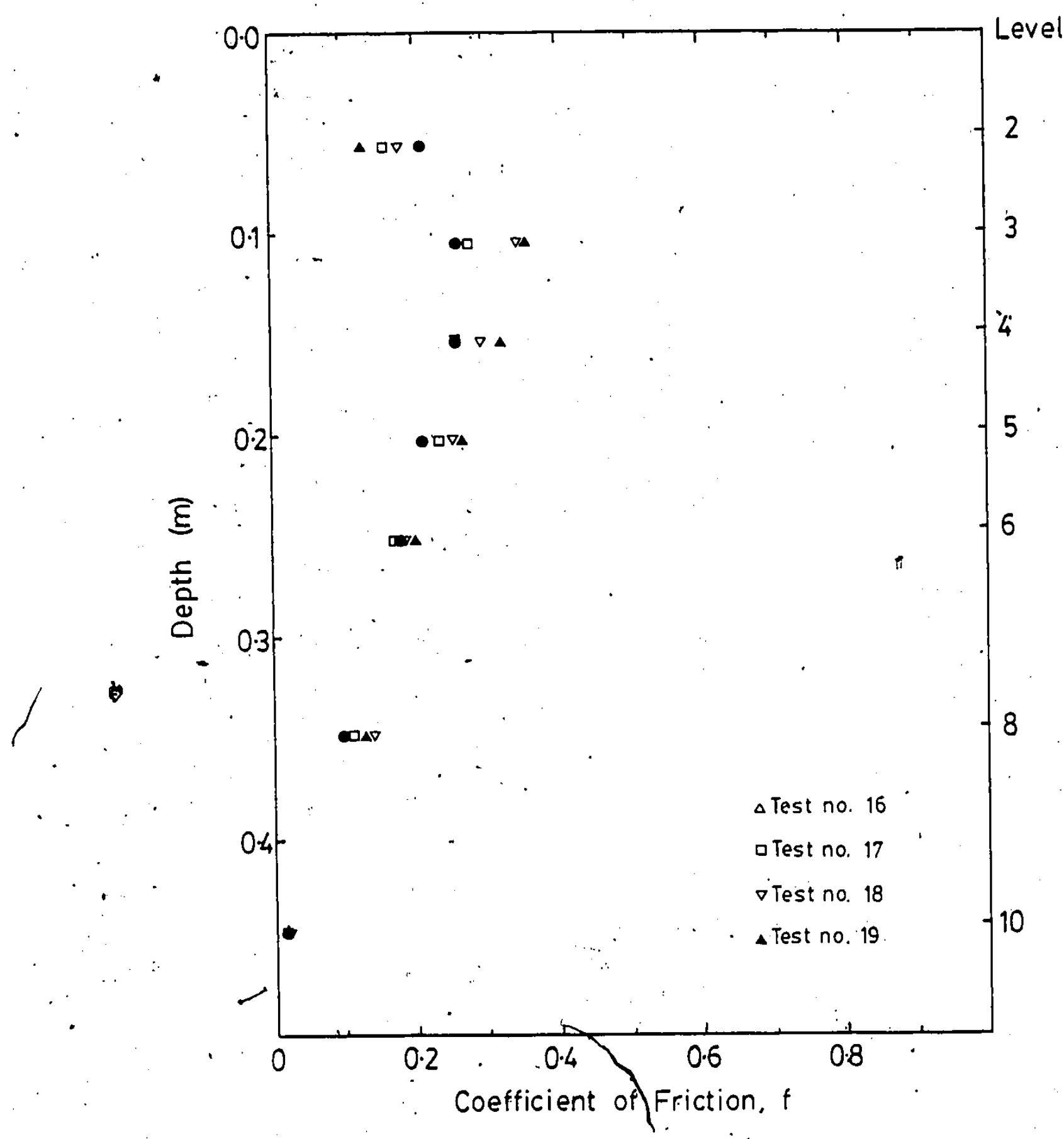

F1g. 5.6 Coefficient of Moblifized Soll-Strip Friction as a Function of Depth: Load Location IV. 


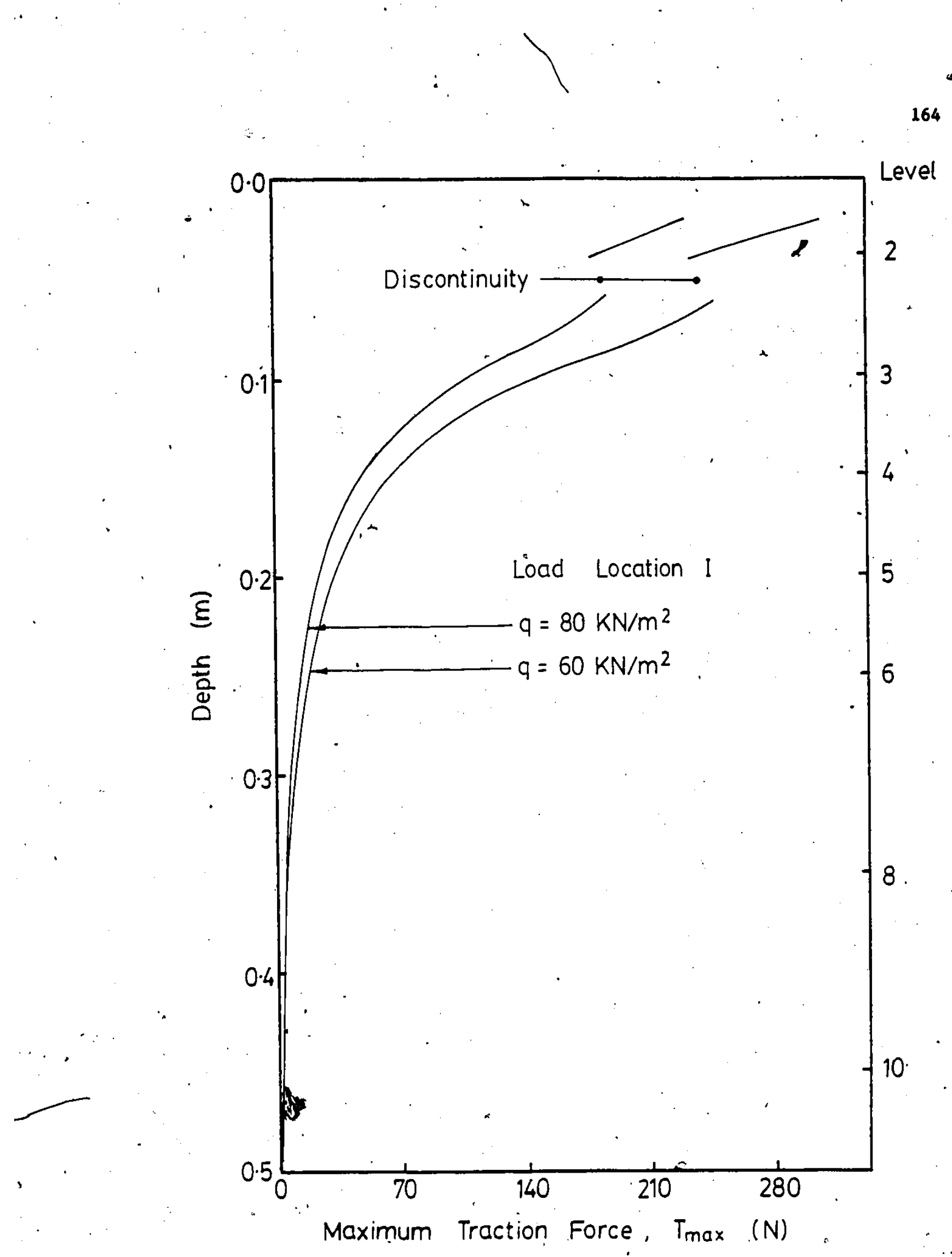

Fig. 5.7 Distribution of Tmax (theroetical), as a Function of Depth. 


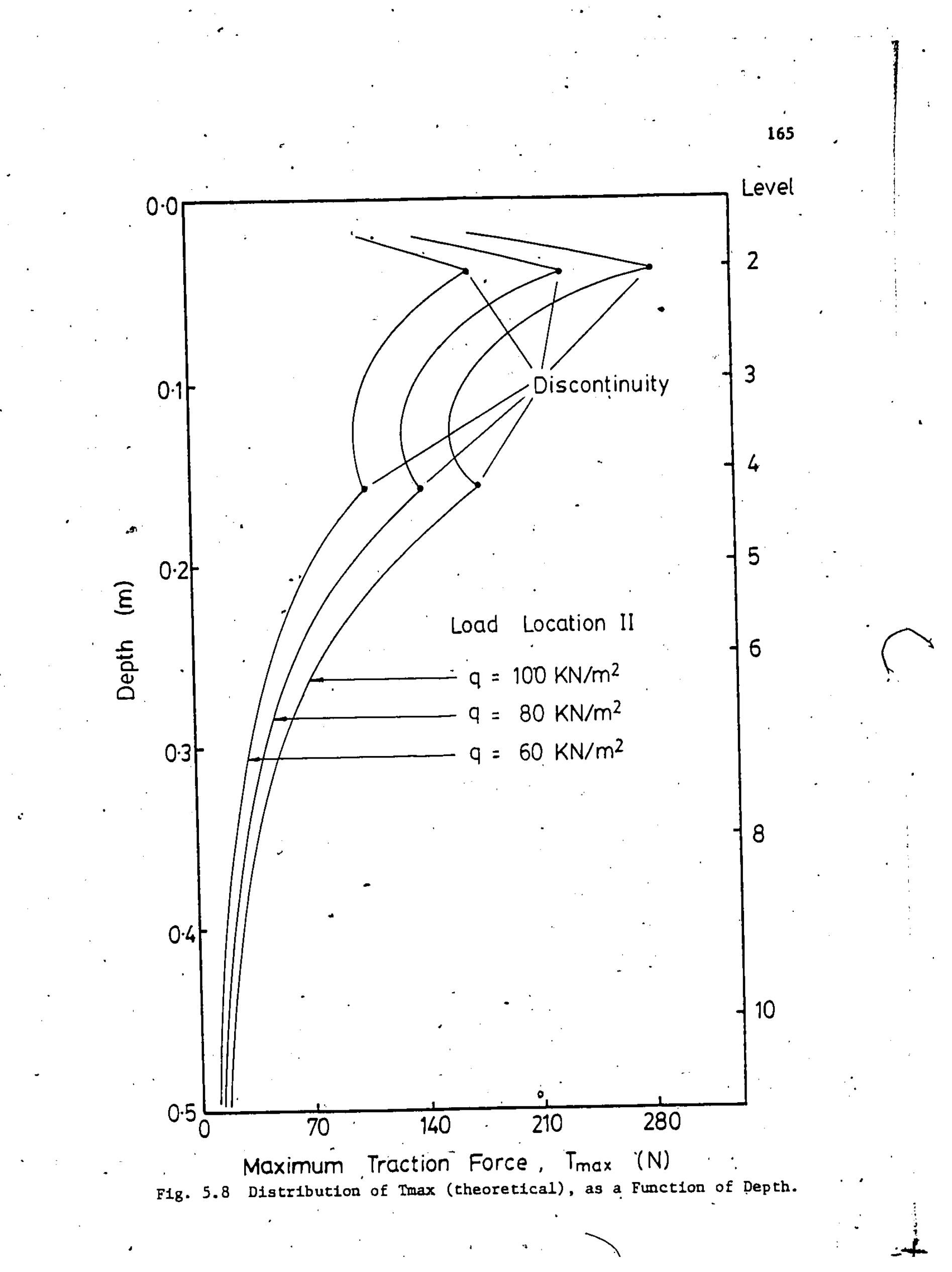




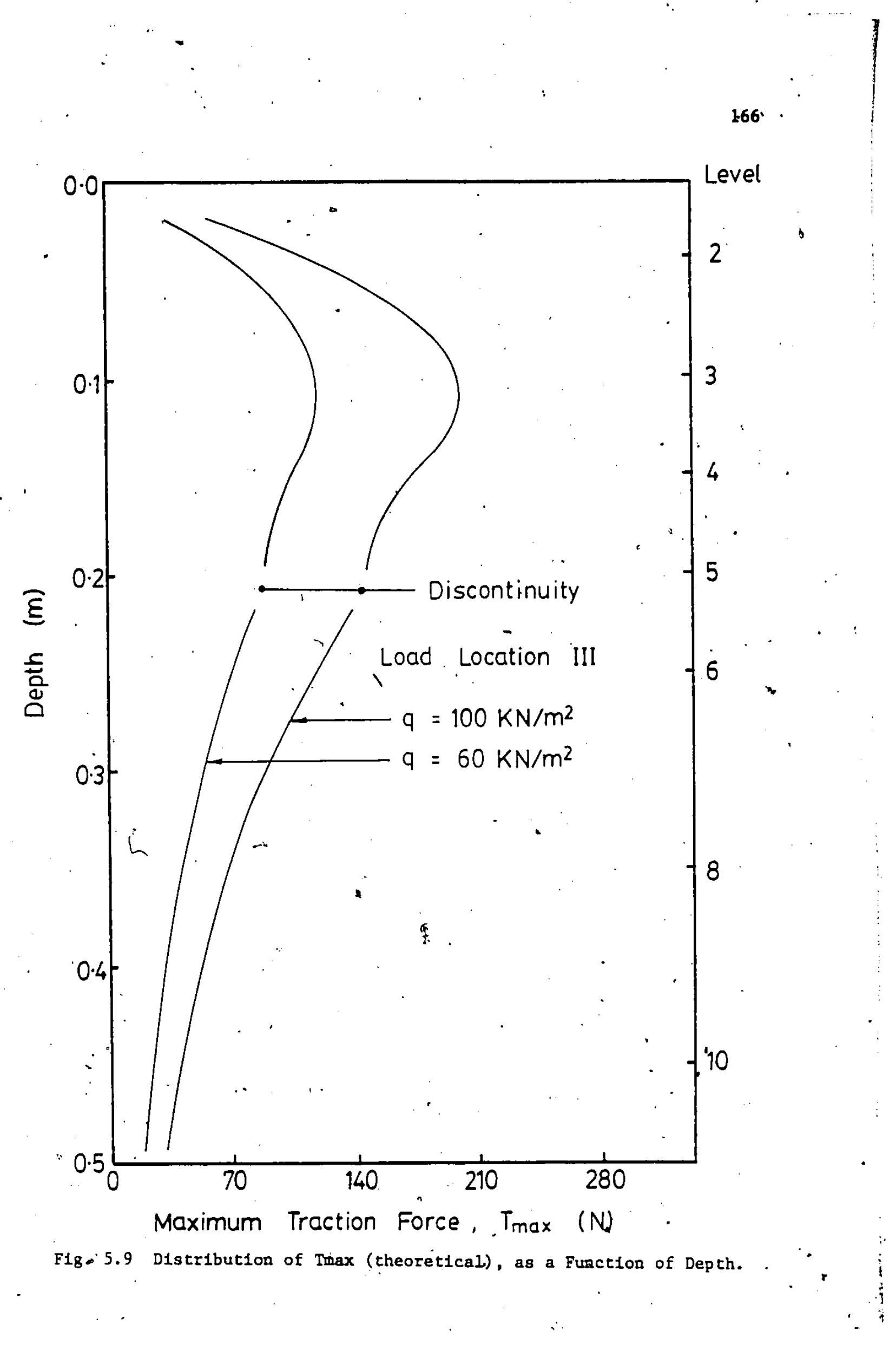




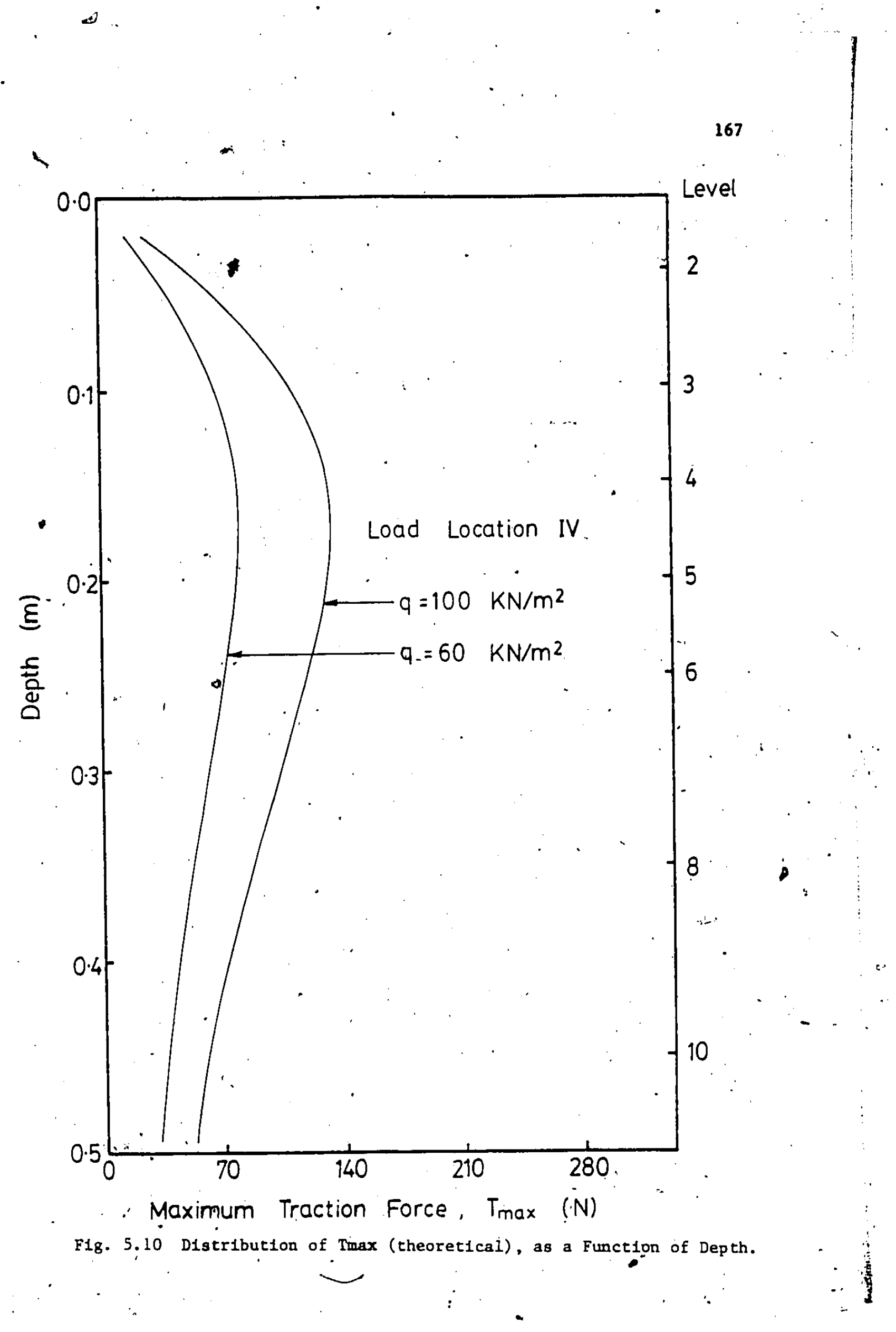




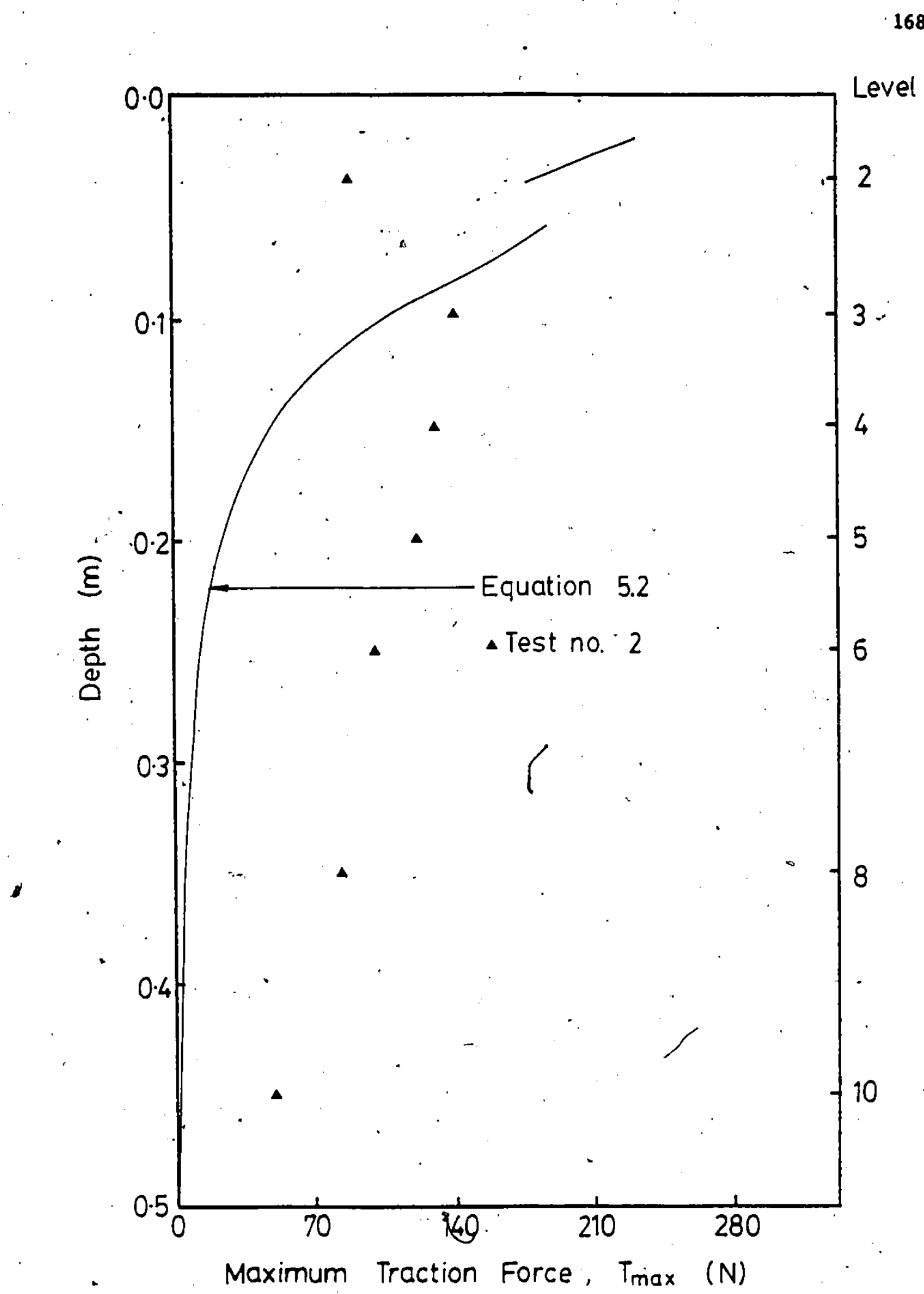

F18. 5.11 Comparison Between Experimental and Theoretical Values of Imax. 


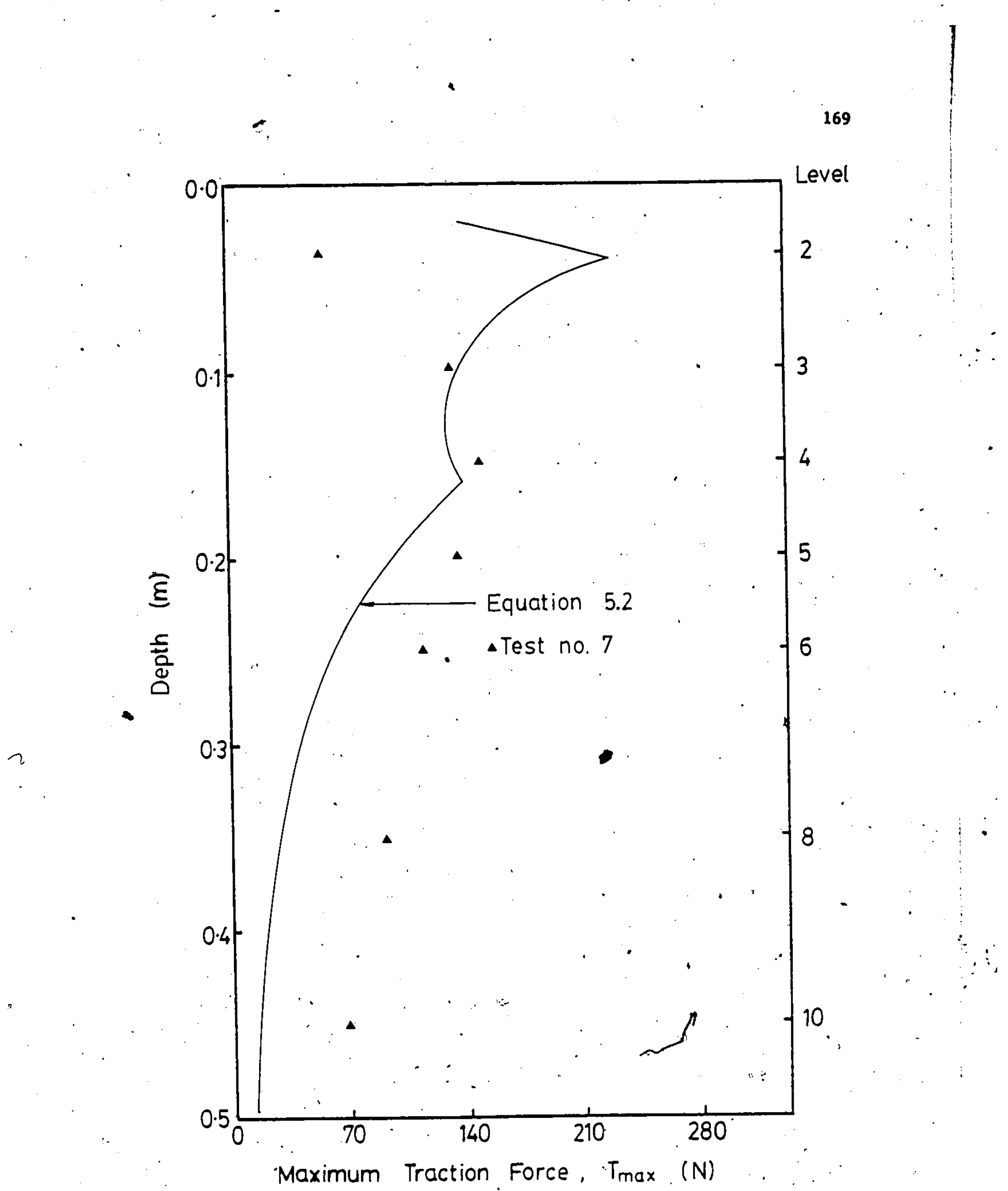

F1g. 5.12 Comparison Between Experimental and.Theoretfcal Values of Tmax. 
s)

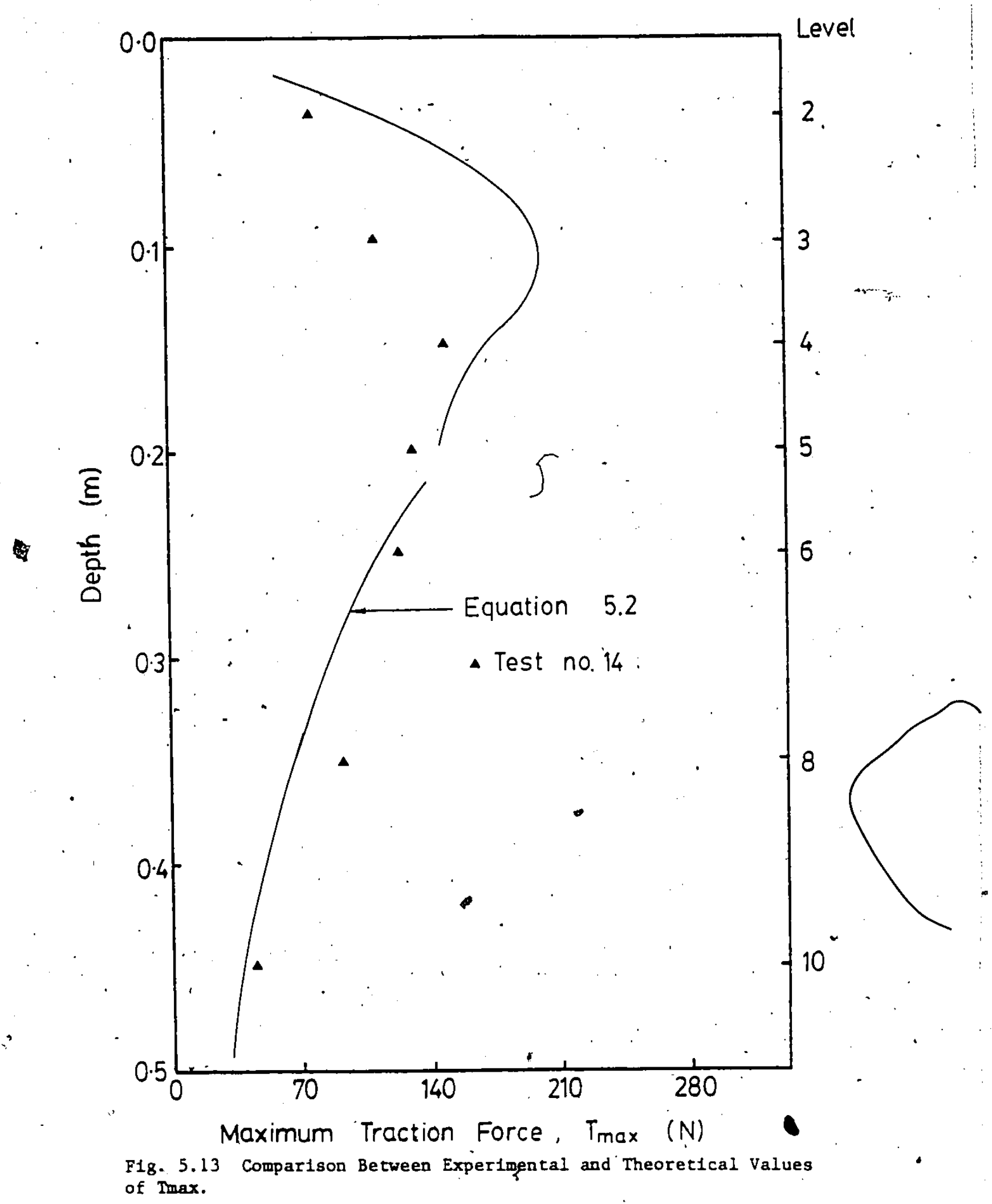

170 


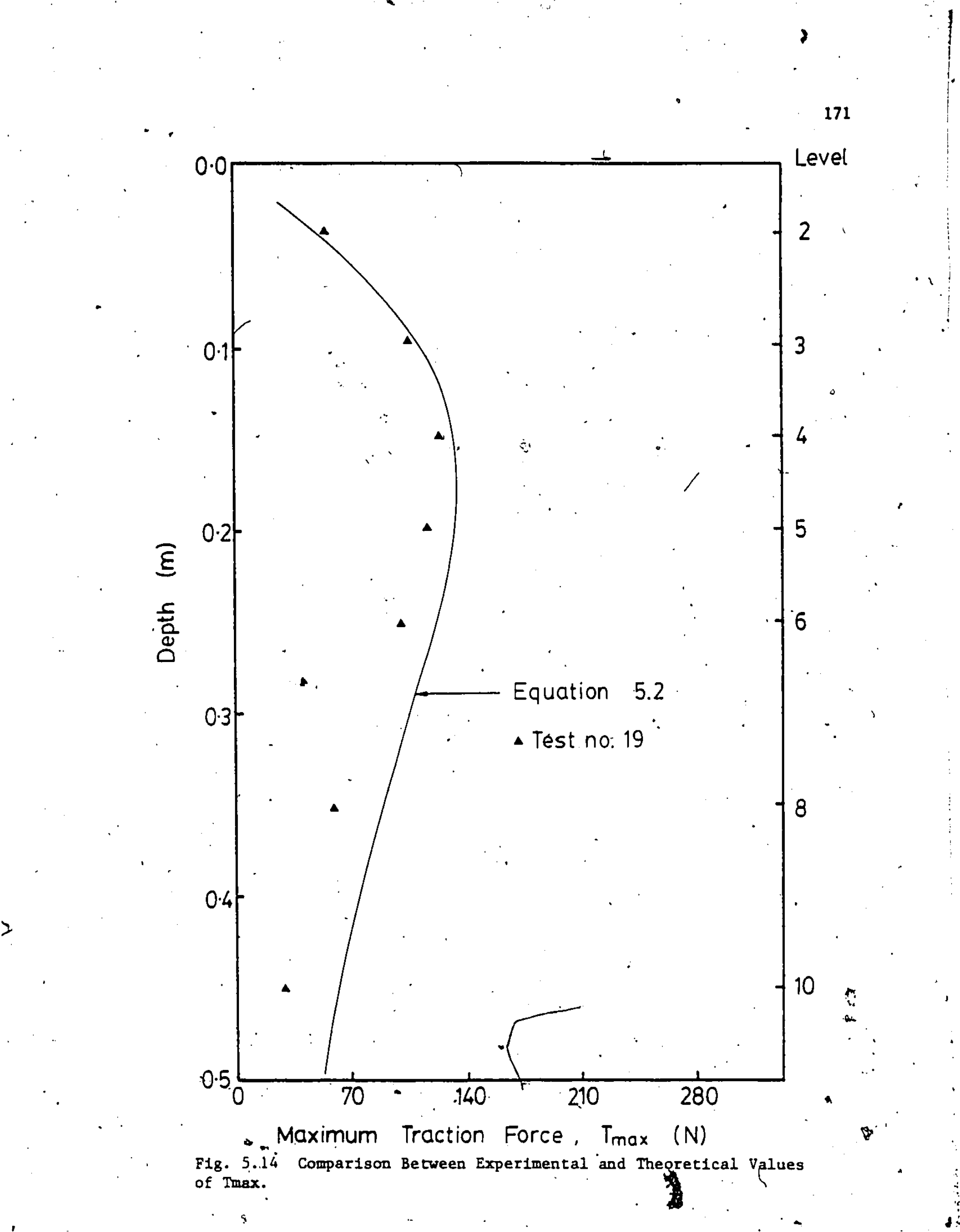




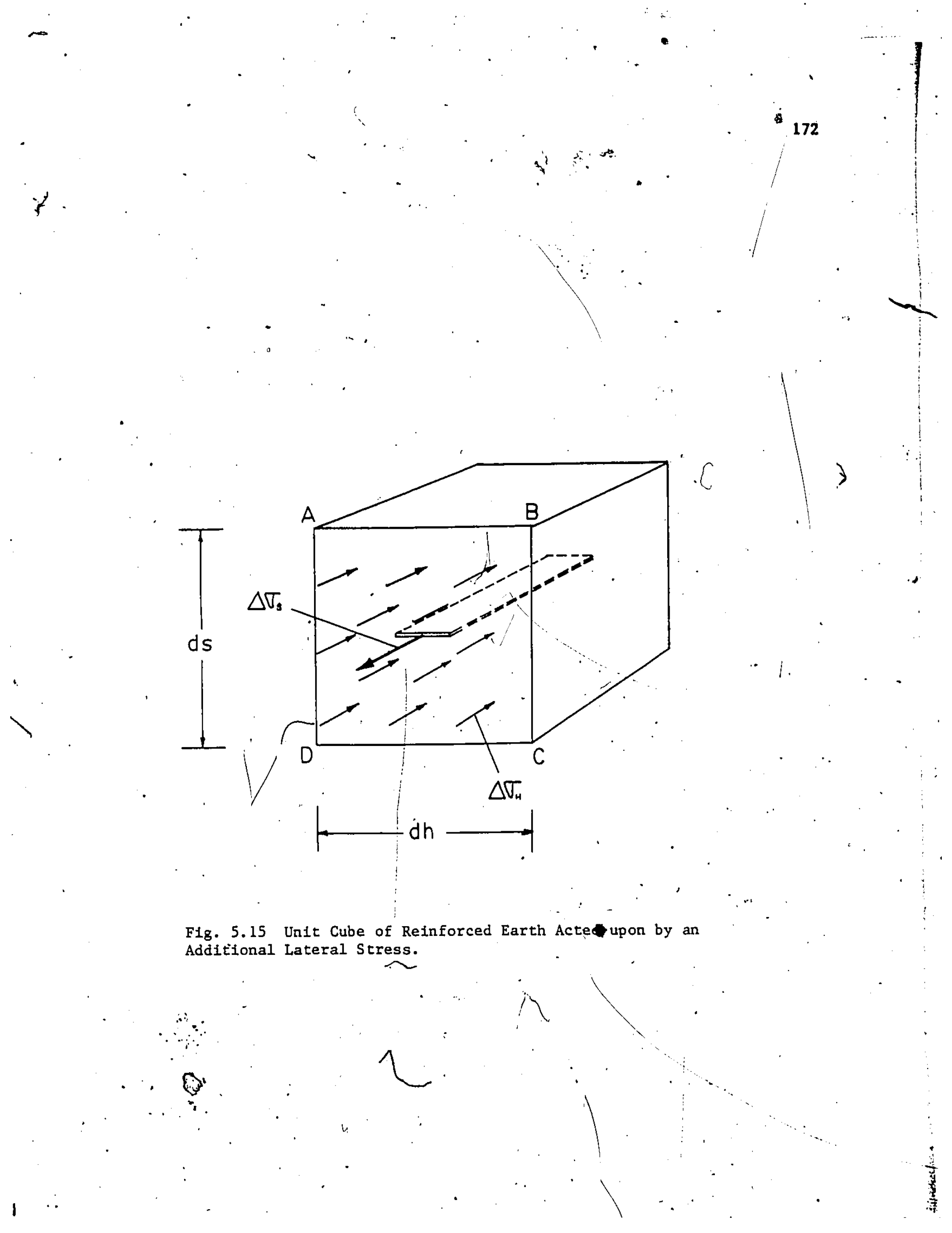




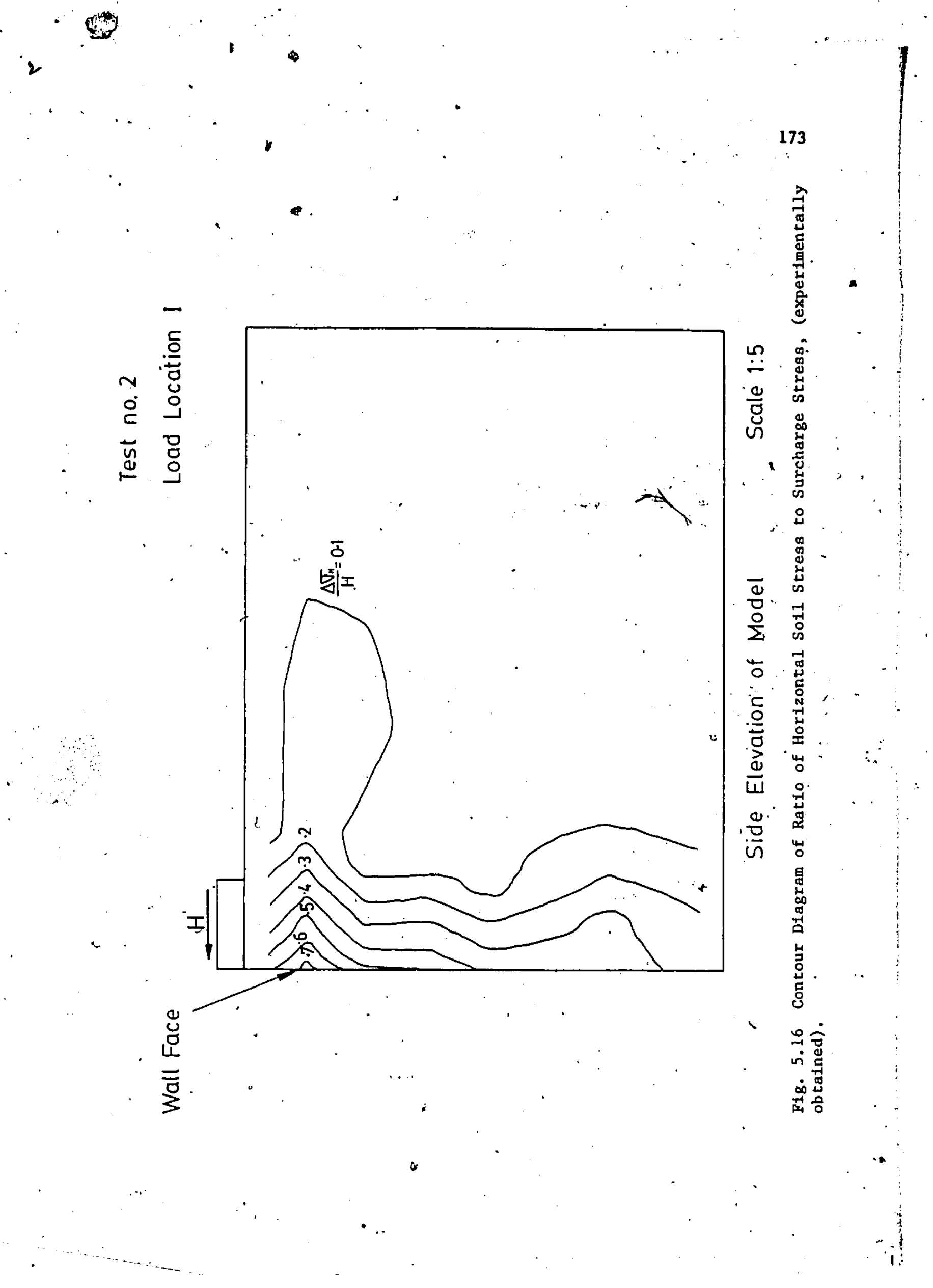


$x+6$

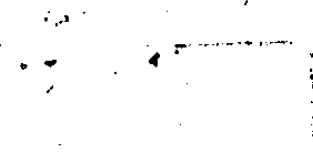

$\checkmark$

$\ldots \cdot:=$

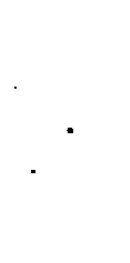

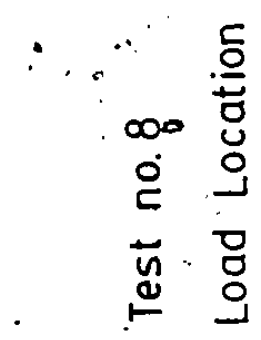

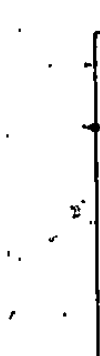

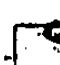

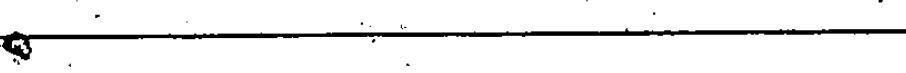

$=$
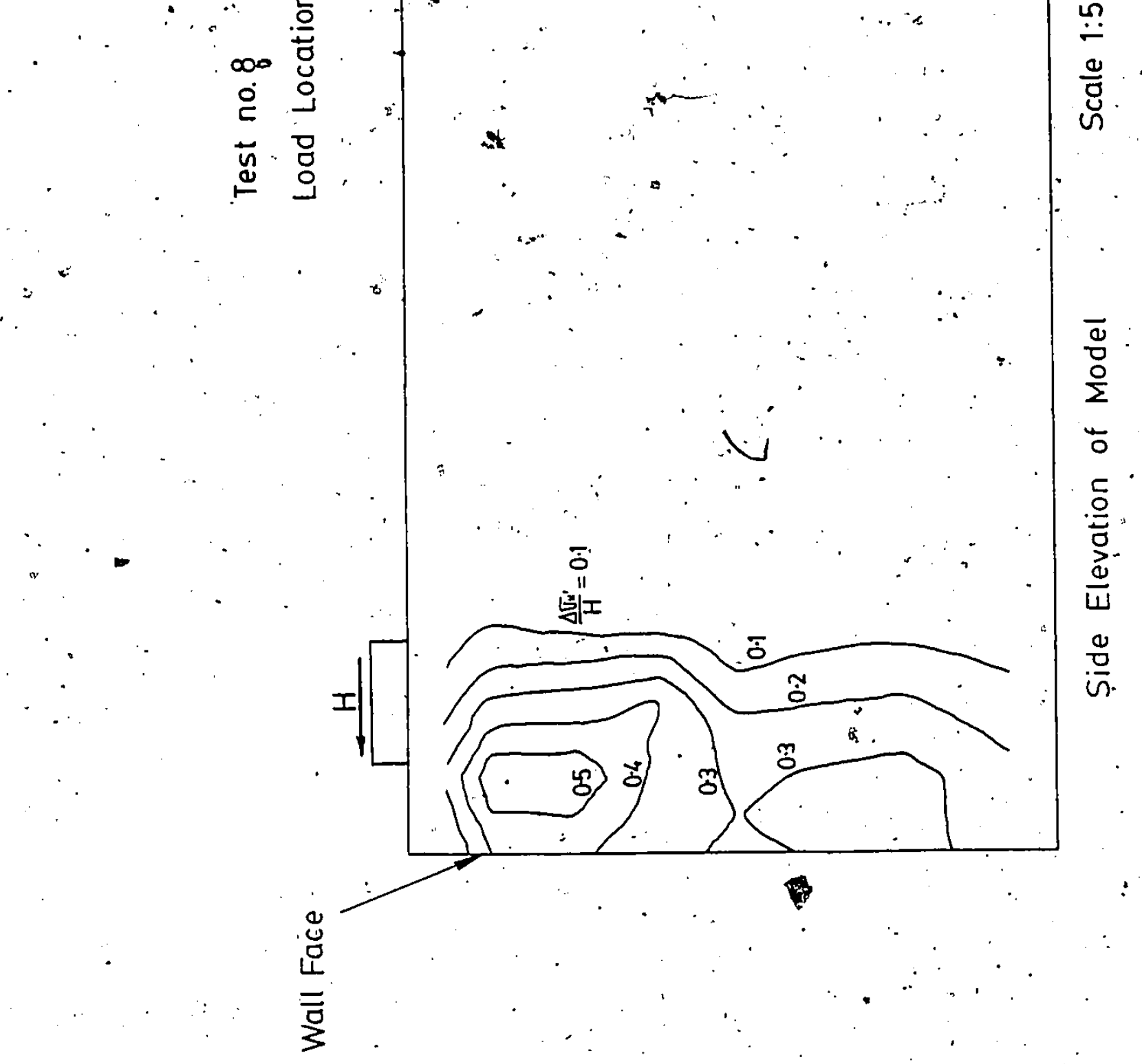

I

눙

174

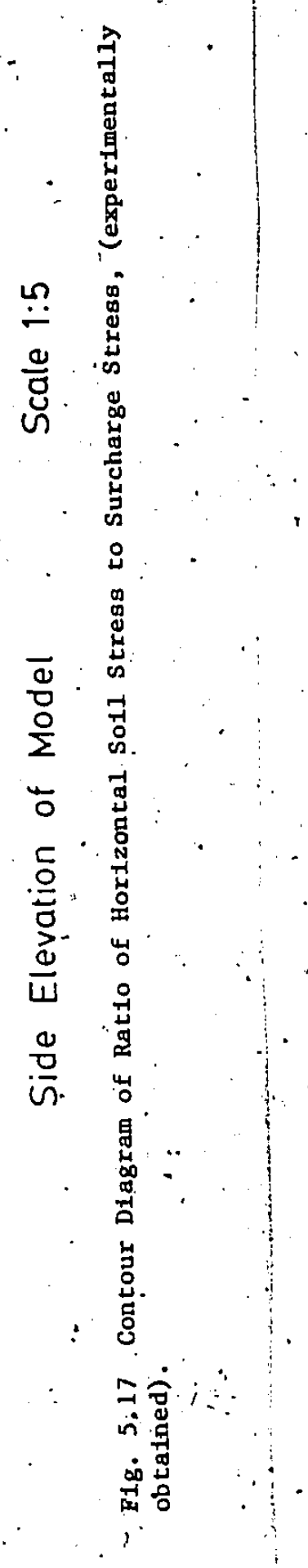




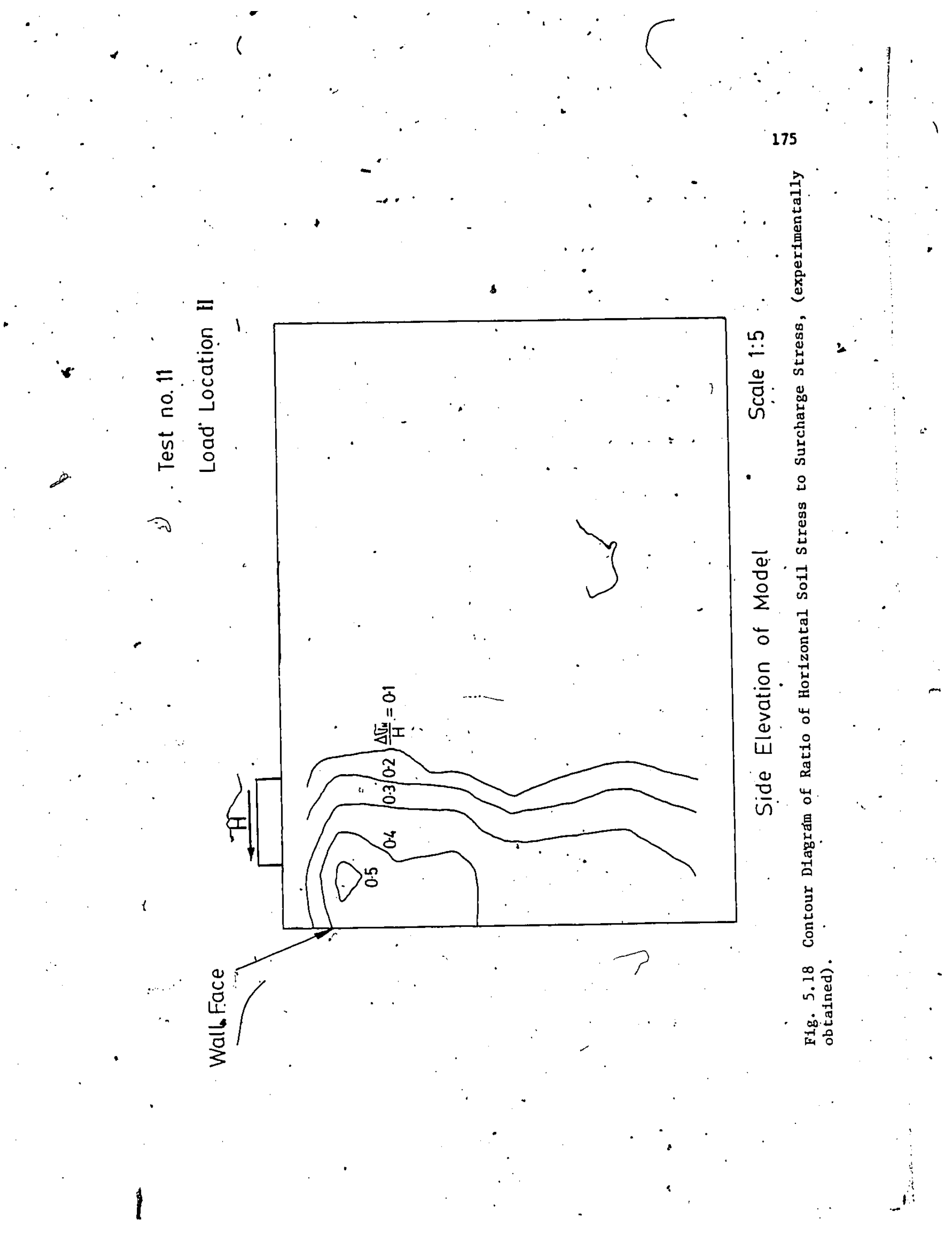



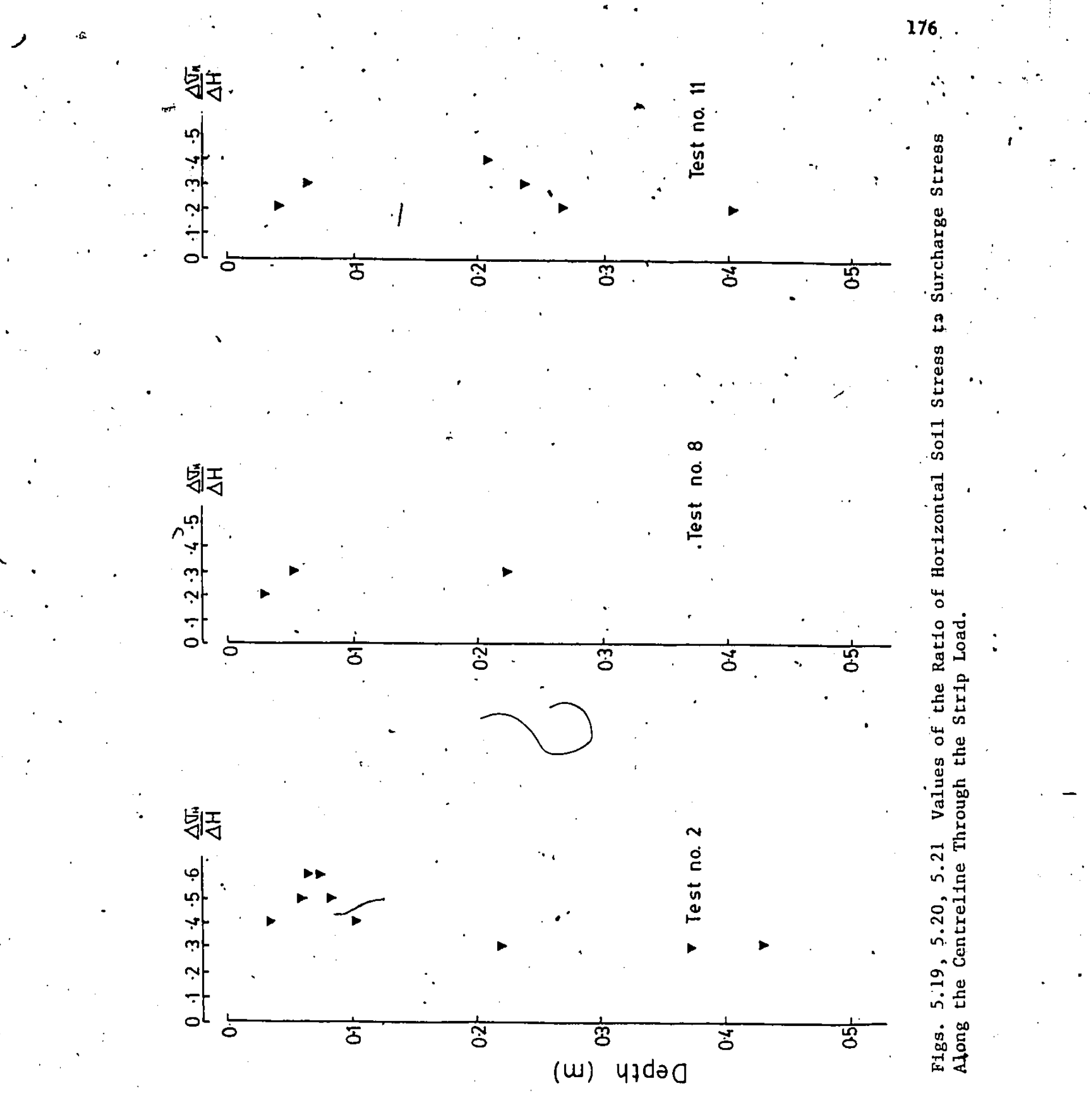


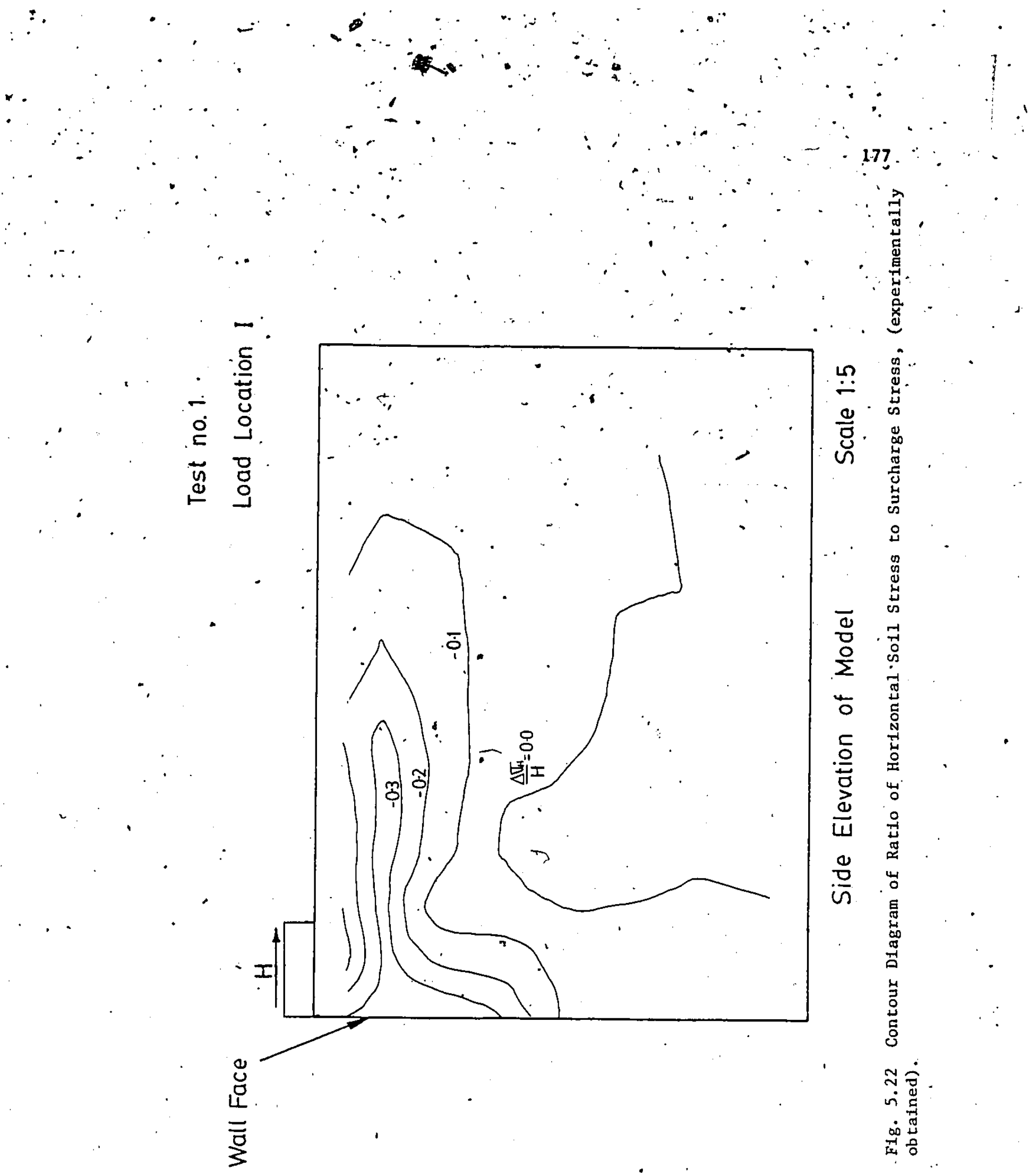




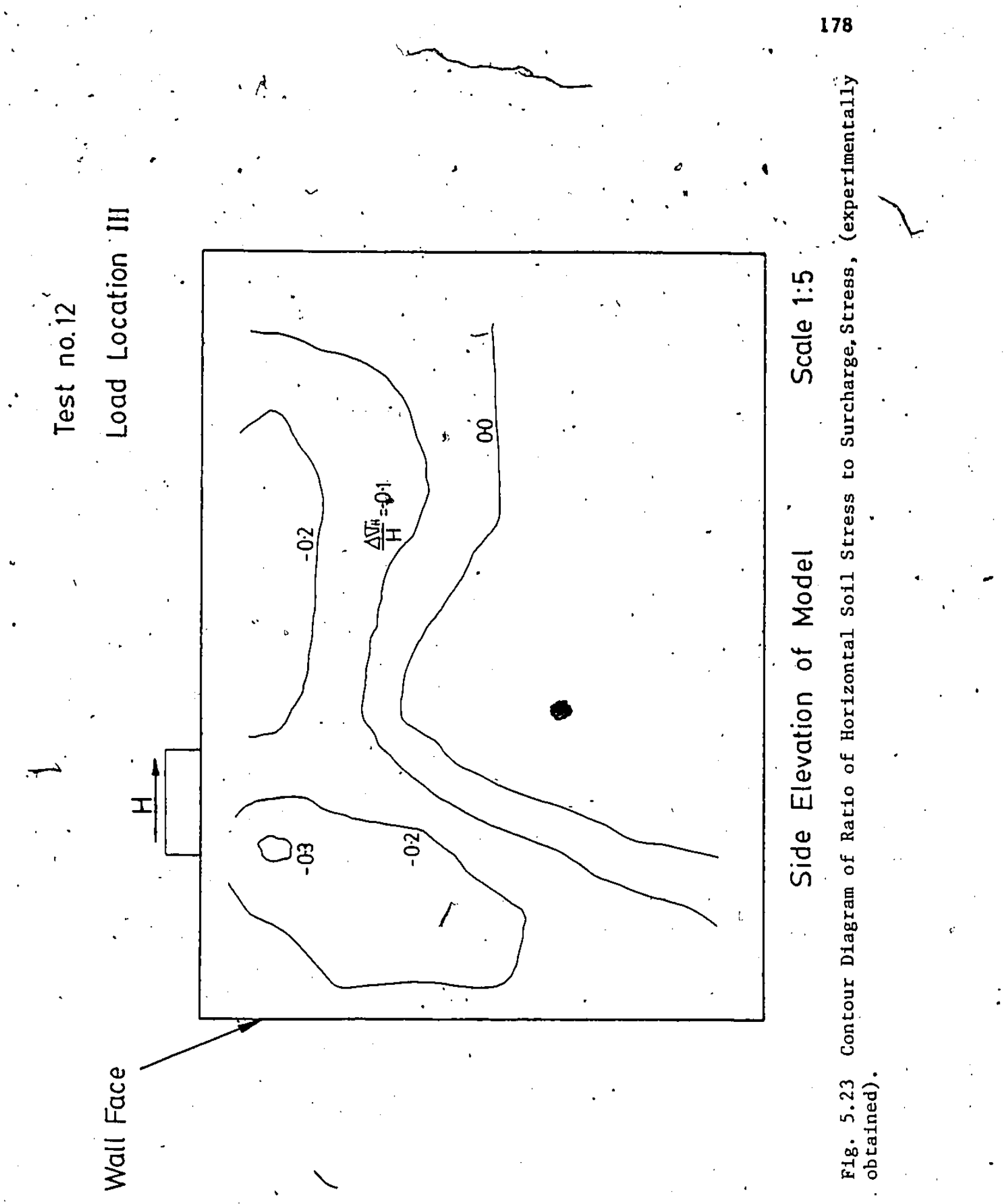


$1-2 b-1$

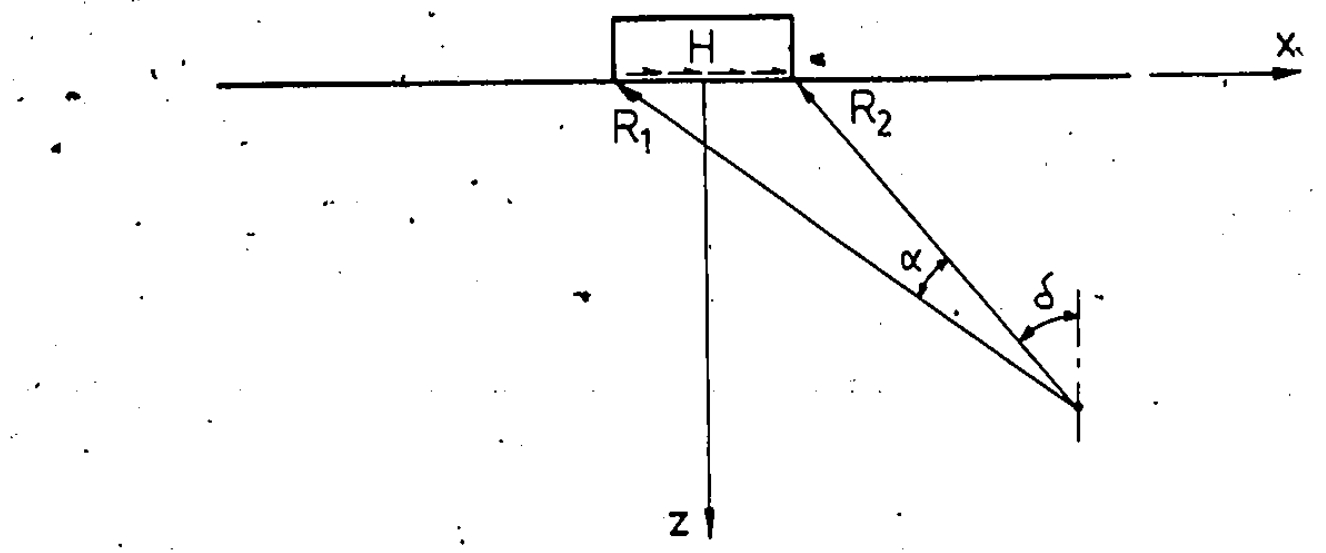

F1g. 5.24 Infinite Horizontal Strip Load on Semi-Infinite Elastic Medium.

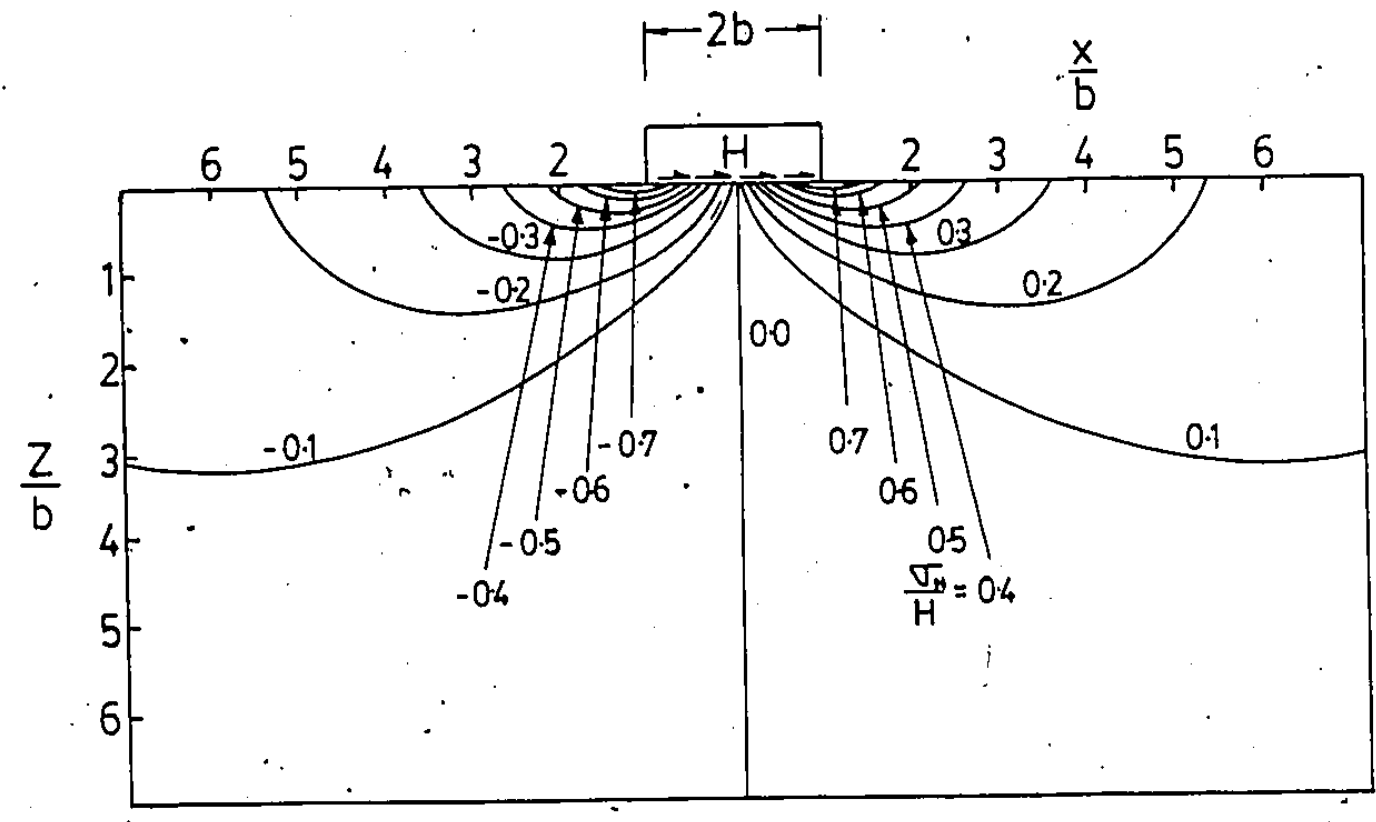

Contours of the Horizontal Soil Stress:Surcharge Stress Ratio

Fig. 5.25 Dimensioniess Solution to Equation 5.9.

\section{4}




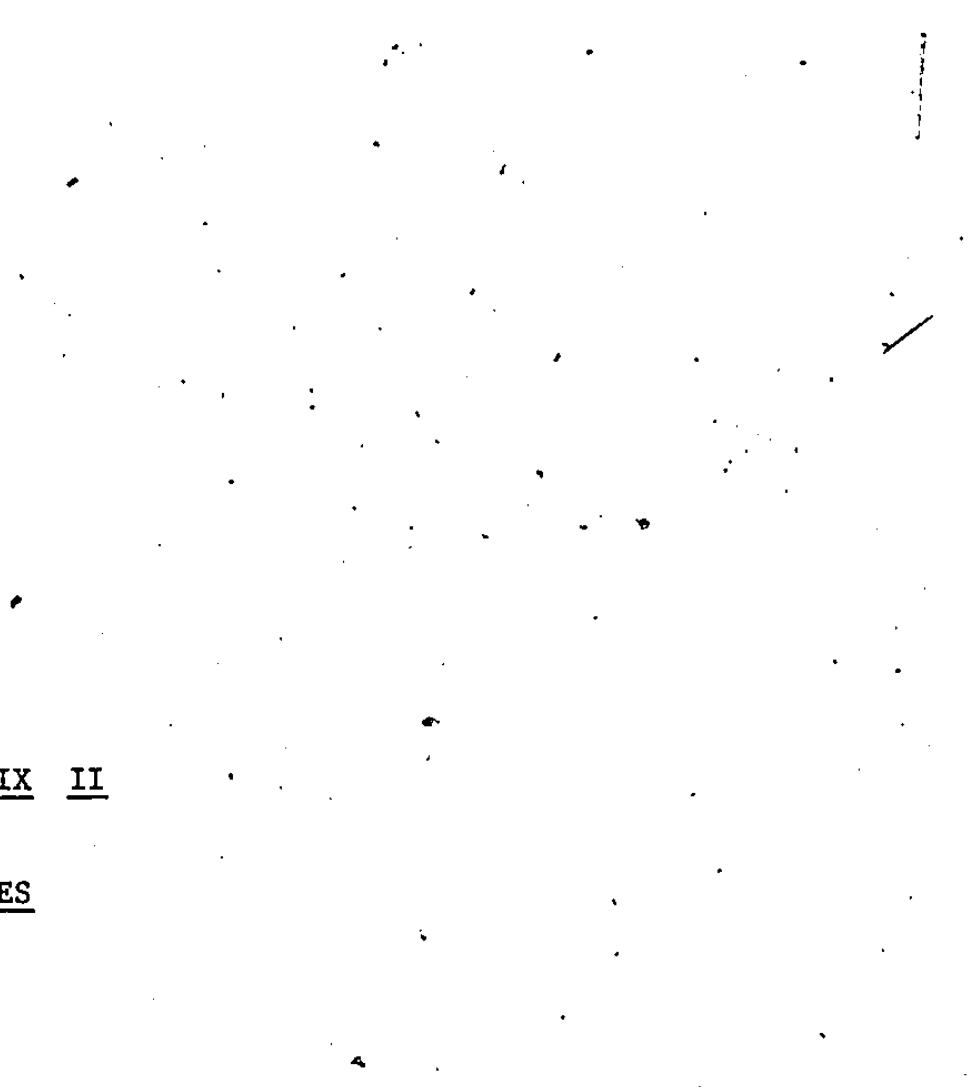

APPENDIX II

4

\section{TABLES}

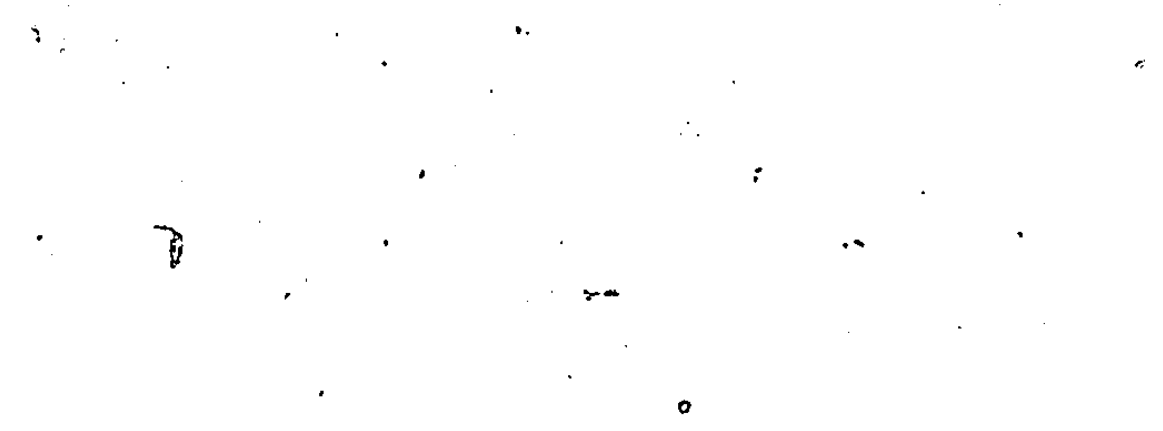


Table 3.1 Loading Schedule for Experimental Programe

181

\begin{tabular}{|c|c|c|c|c|c|}
\hline \multirow[b]{2}{*}{ Test No. } & \multirow[b]{2}{*}{ Load } & \multirow[b]{2}{*}{ Location } & \multicolumn{2}{|c|}{ Load Components } & \multirow{2}{*}{ Direction } \\
\hline & & & $\begin{array}{l}\text { Vertical } \\
\dot{q}, \mathrm{kN} / \mathrm{m}^{2}\end{array}$ & $\begin{array}{c}\text { Horlzontal } \\
\mathrm{H}, \mathrm{kN} / \mathrm{m}^{2}\end{array}$ & \\
\hline 1 & & I & 60 & $0,6,12,18,24$ & Away From Wall Face \\
\hline 2 & & I & 60 & $0,5,10$ & - Towards Wall Face \\
\hline 3 & & $I$ & 80 & $0,3,6,9,12,15$ & Away: From Wall Face \\
\hline 4. & & II & $\cdot 60$ & $0,7,14,21$ & Away From Wall Face \\
\hline 5 & & II & 60 & $.0,5,10,15,20$ & Wall Face \\
\hline 6 & & II & 60 & $0,5,10,15,20$ & Wall Face \\
\hline 7 & & II & 80 & $0,14,28$ & Away From Wall Face \\
\hline 8 & & II & 80 & $0,5,10,12 . \dot{8}, 15.6$ & Wall Face \\
\hline 9 & & II & 100 & $0,10,20,30$ & Away From Wall Face \\
\hline 10 & & II & 100 & $0,5,10,15,20$ & Away From Wall Face \\
\hline 11 & . & II & 100 & $0,6.5,13,19.5,26$ & Wall Face \\
\hline 12 & & III & 60 & $0,6,12,18$. & Away From Wall Face \\
\hline 13 & . & III & 60 & $0,5,10,15$ & Wall · Face \\
\hline 14 & & III & 100 & $\begin{array}{l}0,5,10,15,20,2.3 . \\
23.25\end{array}$ & Away From Wall Face \\
\hline 15 & & III & 100 & $0,5,10,15,17: 6^{-}$ & Towards \\
\hline 16 & & IV & 60 & $0,6,12,18,21$ & $\begin{array}{l}\text { Away From Wall Fáce } \\
2 i\end{array}$ \\
\hline 17 & • & IV & 60 & $0,5,10,15,17.4$ & Wall Face \\
\hline 18 & $\cdot$ & IV & 100 & $0,5,10,15,20$ & Away From Wall Face \\
\hline 19 & & IV & 100 & $0,5,10,15,20$ & Wall Face \\
\hline
\end{tabular}
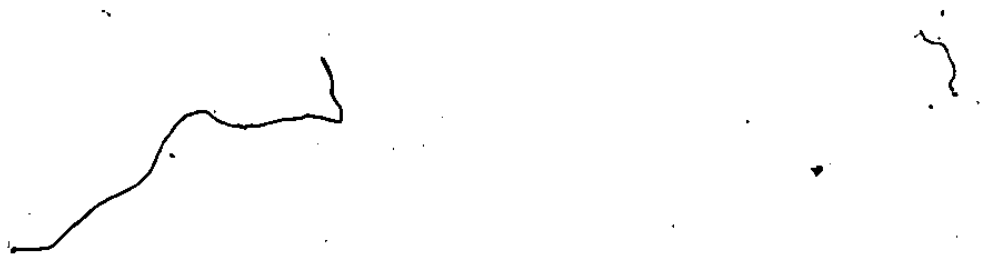
Table 4.1 Values of Strip Stress for Test no. $1, q=60 \mathrm{kN} / \mathrm{m}^{2}$; Load Location I.

\begin{tabular}{|c|c|c|c|c|c|c|}
\hline \multirow{2}{*}{ Strip Level } & \multicolumn{6}{|c|}{ Strip Stress Values, $\mathrm{N} / \mathrm{m}^{2} \times 10^{7}$} \\
\hline & \multicolumn{6}{|c|}{$\mathrm{H}=0 \mathrm{kN} / \mathrm{m}^{2}$} \\
\hline \multirow[t]{2}{*}{$\begin{array}{r}2^{\circ} \\
3 \\
4 \\
5 \\
6 \\
8 \\
10\end{array}$} & $\begin{array}{l}13.26 \\
20.33 \\
19.95 \\
16.50 \\
14.17 \\
13.17 \\
10.08\end{array}$ & $\begin{array}{r}14.18 \\
22.99 \\
0.00 \\
18.61 \\
16.33 \\
14.32 \\
9.63\end{array}$ & $\begin{array}{r}3.53 \\
12.16 \\
15.35 \\
13.99 \\
14.08 \\
12.12 \\
3.85\end{array}$ & $\begin{array}{r}1.20 \\
10.16 \\
10.79 \\
9.29 \\
9.61 \\
4.86 \\
-0.54 \\
\end{array}$ & $\begin{array}{r}2.78 \\
6.32 \\
6.53 \\
0.00 \\
3.97 \\
-0.23 \\
\end{array}$ & $\begin{array}{l}0.73 \\
2.69 \\
2.78 \\
1.83 \\
1.27\end{array}$ \\
\hline & 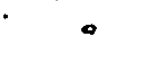 & & \multicolumn{2}{|c|}{$\mathrm{H}=6 \mathrm{kN} / \mathrm{m}^{2}$} & & \\
\hline \multirow[t]{2}{*}{$\begin{array}{r}2 \\
3 \\
4 \\
5 \\
6 \\
8 \\
10\end{array}$} & $\begin{array}{r}10.54 \\
17.76 \\
19.05 \\
1.5 .36 \\
14.00 \\
12.80 \\
9.87\end{array}$ & $\begin{array}{r}13.19 . \\
21.54^{\circ} \\
0.00 \\
18.93 \\
16.33 \\
14.25 \\
9.80\end{array}$ & $\begin{array}{r}1.63 \\
9.53 \\
15.29 \\
14.80 \\
15.05 \\
12.41 \\
4.10\end{array}$ & $\begin{array}{r}-0.37 \\
7.64 \\
10.13 \\
9.84 \\
10.43 \\
5.25 \\
-0.50\end{array}$ & $\begin{array}{r}-0.71 \\
.3 .95 \\
5.57 \\
0.00 \\
4.21 \\
-0.13\end{array}$ & $\begin{array}{r}-0.06 \\
1.41 \\
2.01 \\
1.46 \\
1.10\end{array}$ \\
\hline & \multicolumn{6}{|c|}{$\mathrm{H}=12 \mathrm{kN} / \mathrm{m}^{2}$} \\
\hline \multirow[t]{2}{*}{$\begin{array}{r}2 \\
3 \\
4 \\
5 \\
6 \\
8 \\
10\end{array}$} & $\begin{array}{r}7.39 \\
13.84 \\
15.91 \\
12.82 \\
13.22 \\
11.99 \\
9.30\end{array}$ & $\begin{array}{r}13.66 \\
18.79 \\
0.00 \\
18.05 \\
15.99 \\
13.77 \\
9.71\end{array}$ & $\begin{array}{r}0.67 \\
6.21 \\
14.81 \\
15.65 \\
16.09 \\
12.83 \\
4.40\end{array}$ & $\begin{array}{r}-0.91 \\
4.33 \\
8.54 \\
10.17 \\
11.56 \\
5.93 \\
-0.50\end{array}$ & $\begin{array}{r}-7.73 \\
-\Upsilon 0.90 \\
3.53 \\
0.00 \\
4.30 \\
-0.11\end{array}$ & $\begin{array}{r}-0.62 \\
-0.28 \\
0.56 \\
0.73 \\
0.63\end{array}$ \\
\hline & \multicolumn{2}{|l|}{ ' } & \multicolumn{2}{|c|}{$\dot{\mathrm{H}}=18 \mathrm{kN} / \mathrm{m}^{2}$} & & $\theta^{\circ}$ \\
\hline $\begin{array}{r}2 \\
3 \\
4 \\
5 \\
6 \\
8 \\
10\end{array}$ & $\begin{array}{r}6.39 \\
11.44 \\
12.28 \\
9.99 \\
12.20 \\
10.98 \\
8.71\end{array}$ & $\begin{array}{r}15.07 \\
16.44 \\
0.00 \\
15.88 \\
14.79 \\
13.09 \\
9.57\end{array}$ & $\begin{array}{r}0.69 \\
4.20 \\
14.36 \\
-\quad 15.90 \\
16.49 \\
-13.11 \\
4.79\end{array}$ & $\begin{array}{r}-0.84 \\
2.46 \\
7.20 \\
10.15 \\
12.43 \\
6.56 \\
-0.50\end{array}$ & $\begin{array}{r}-2.09 \\
-0.75 \\
1.94 \\
0.00 \\
4.26 \\
-0.06\end{array}$ & $\begin{array}{r}-1.01 \\
-1.29 \\
-0.46 \\
0.12 \\
2.74 \\
\end{array}$ \\
\hline & \multicolumn{6}{|c|}{$\mathrm{H}=24 \mathrm{KN} / \mathrm{m}^{2}$} \\
\hline $\begin{array}{r}2 \\
3 \\
4 \\
5 \\
6 \\
8 \\
10\end{array}$ & $\begin{array}{r}7.15 \\
10.68 \\
9.95 \\
7.80 \\
11.28 \\
10.03 \\
8.10\end{array}$ & $\begin{array}{r}17.31 \\
14.91 \\
0.00 \\
13.75 \\
13.39 \\
12.31 \\
9.33\end{array}$ & $\begin{array}{r}2.85 \\
2.28 \\
13.91 \\
15.79 \\
16.38 \\
13.19 \\
5.05\end{array}$ & $\begin{array}{r}-0.16 \\
0.84 \\
6.17 \\
10.02 \\
12.97 \\
7.01 \\
-0.54\end{array}$ & $\begin{array}{r}-3.23 \\
-1.73 \\
00.84 \\
0.00 \\
4.21 \\
-0.02\end{array}$ & $\begin{array}{r}-1.14 \\
-2.11 \\
-1.13 \\
-0.32 \\
0.04\end{array}$ \\
\hline
\end{tabular}

note : strain gauges 1 to 39 read left to right from bottom of each table upwards.

: zero stress values indicate faulty strain gauge. 
Table 4.2 Values of Strip ştress for Test no. $2, q=60 \mathrm{kN} / \mathrm{m}^{2}$; Load Location I; Load Towards the Wall Face.

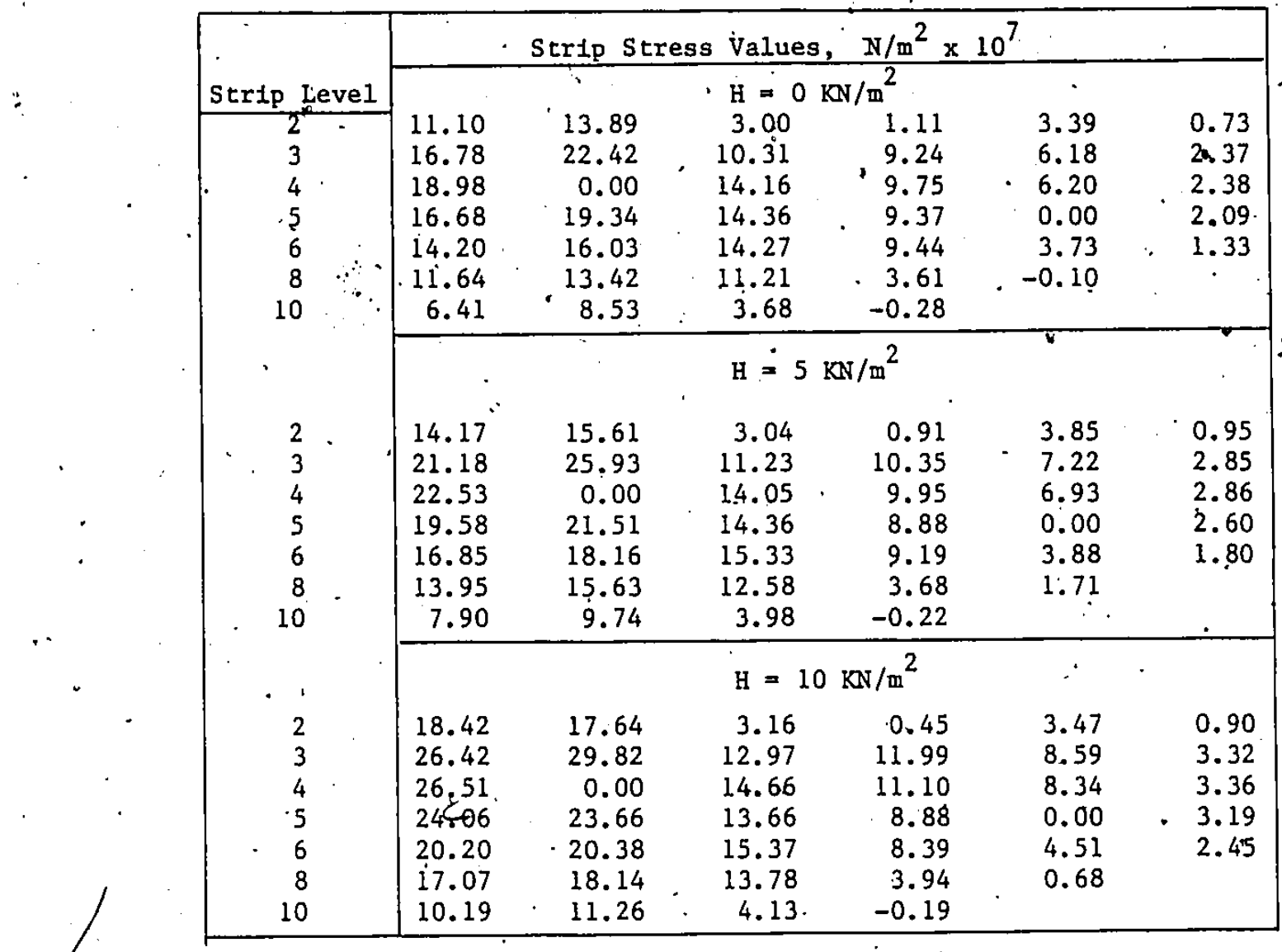


Table 4.3 Values of 5 trip Stress for Test no. $3, q=80 \mathrm{kN} / \mathrm{m}^{2}$;

184 Load Lucation I; Load Away From the Wall Face.

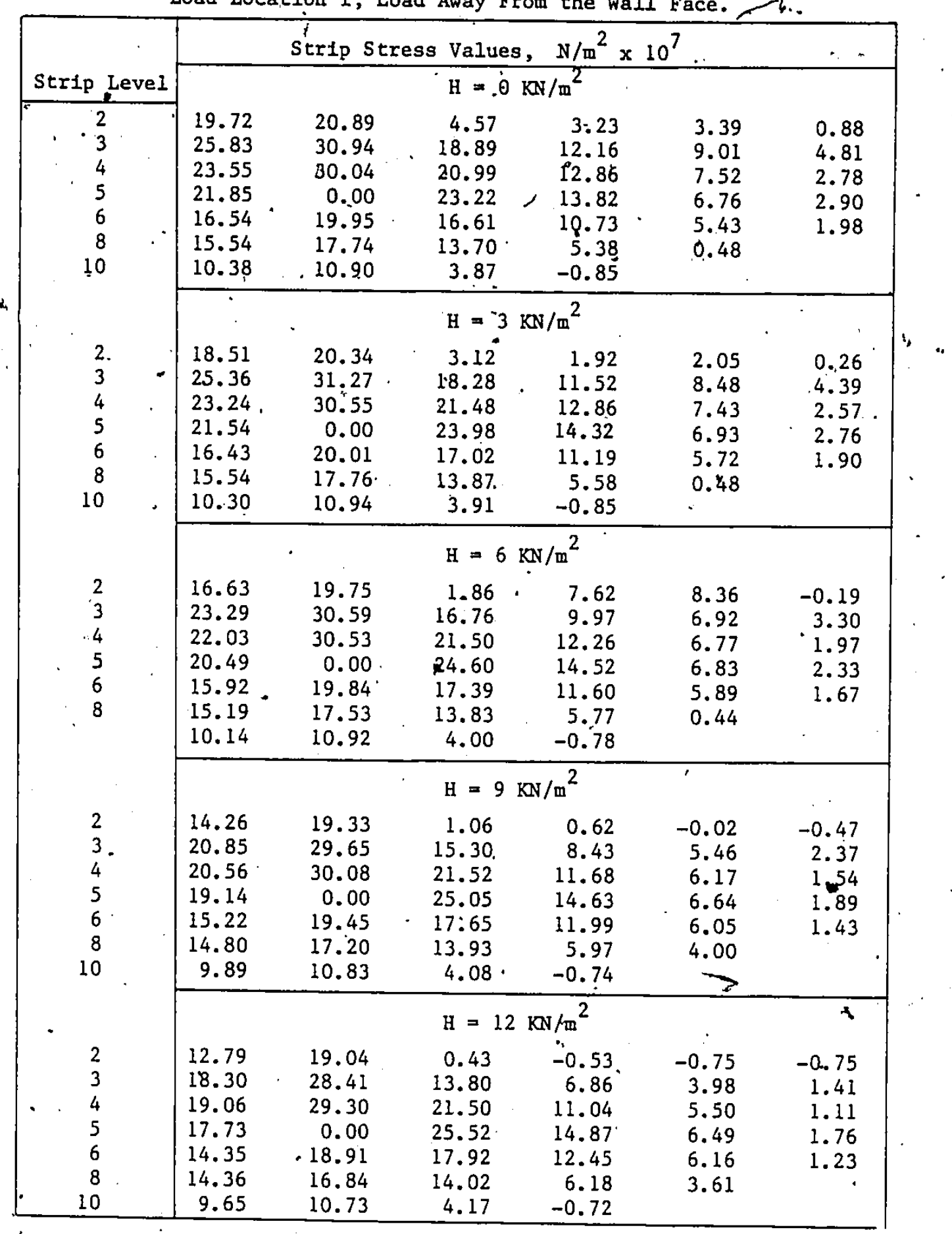


Table 4.3 (cont.) Values of Strip Stress for Test no. $3 ; \mathrm{q}=80 \mathrm{kN} / \mathrm{m}^{2}$; Load Location I; Load Away From the Wall Face.

\begin{tabular}{|c|c|c|c|c|c|c|}
\hline \multirow[b]{2}{*}{ Strip Level } & \multicolumn{6}{|c|}{ Strip stress Values, $\mathrm{N} / \mathrm{m}^{2} \times 10^{7}$} \\
\hline & & & $\mathrm{H}=$ & $\mathrm{kN} / \mathrm{m}^{2}$ & $\cdot$ & \\
\hline $\begin{array}{r}2 \\
3 \\
4 \\
5 \\
6 \\
6 \\
8 \\
10\end{array}$ & $\begin{array}{r}11.17 \\
15.76 \\
17.79 \\
16.76 \\
13.74 \\
14.05 \\
9.43\end{array}$ & $\begin{array}{r}18.94 \\
26.86 \\
28.34 \\
0.00 \\
18.51 \\
16.63 \\
10.72\end{array}$ & $\begin{array}{r}-0.16 \\
12.25 \\
21.69 \\
26.26 \\
18.32 \\
14.44 \\
4.41\end{array}$ & $\begin{array}{r}-1.07 \\
5.27 \\
10.46 \\
15.24 \\
13.10 \\
6.66 \\
-0.63\end{array}$ & $\begin{array}{r}-1.65 \\
2.44 \\
4.86 \\
6.38 \\
6.43 \\
0.42\end{array}$ & $\begin{array}{r}-1.05 \\
4.01 \\
0.68 \\
1.61 \\
1.14 \\
\end{array}$ \\
\hline
\end{tabular}




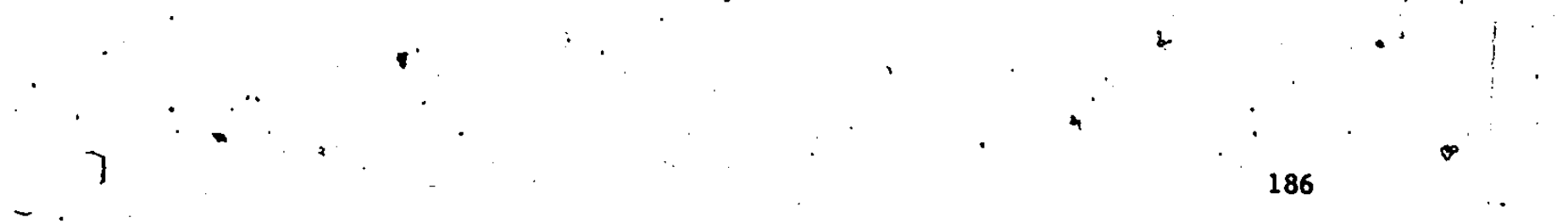

Table 4.4 Values of Strip Stress for Test no. 4, q = $60 \mathrm{kN} / \mathrm{m}^{2} ; \cdots$ Load Location II; Load Away From the Wall Face.

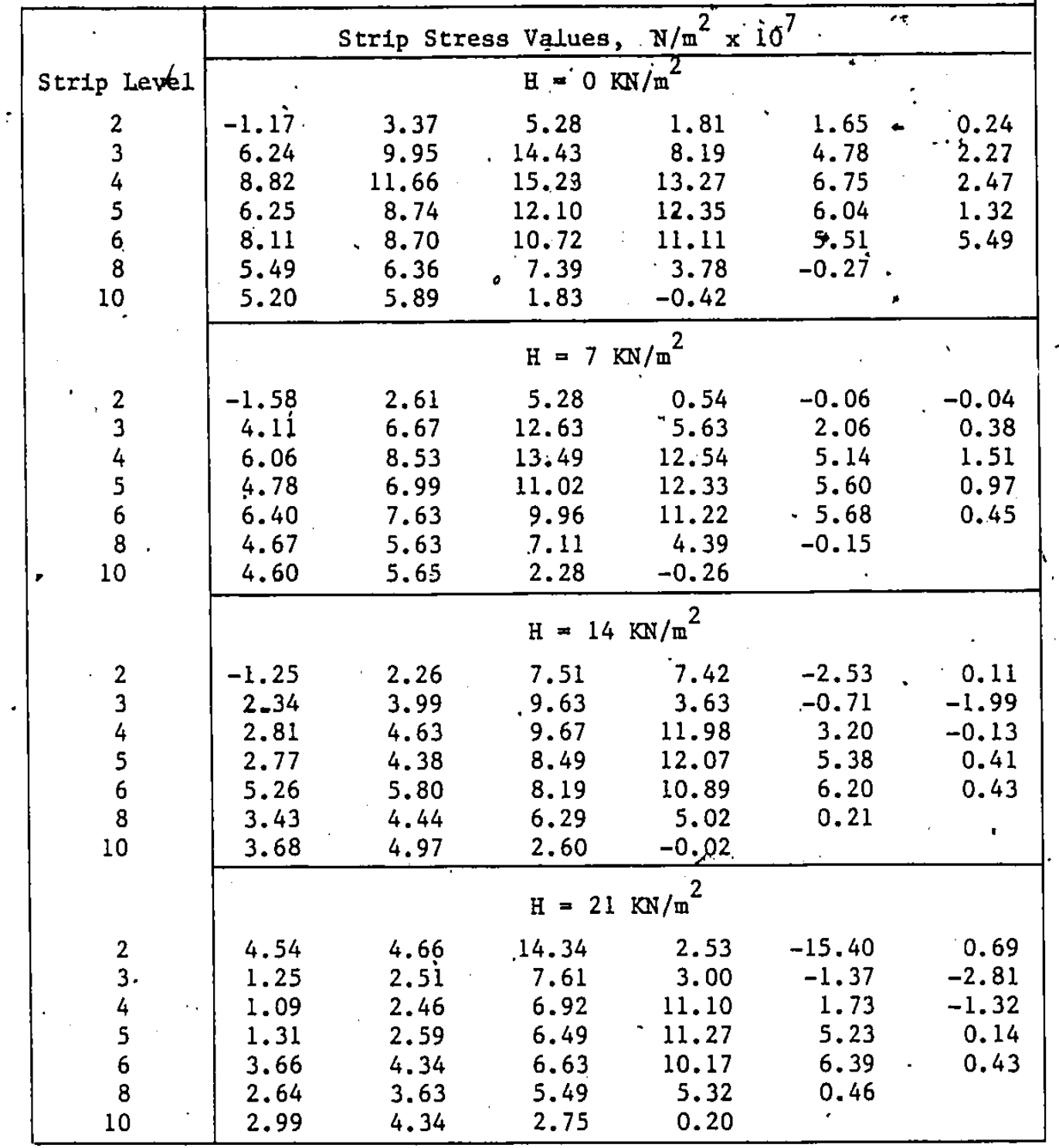


Table 4.5 Values of Strip Stress for. Test no. $5, q=60 \mathrm{kN} / \mathrm{m}^{2}$;
Load Location II; Load Towards the Wall Face.

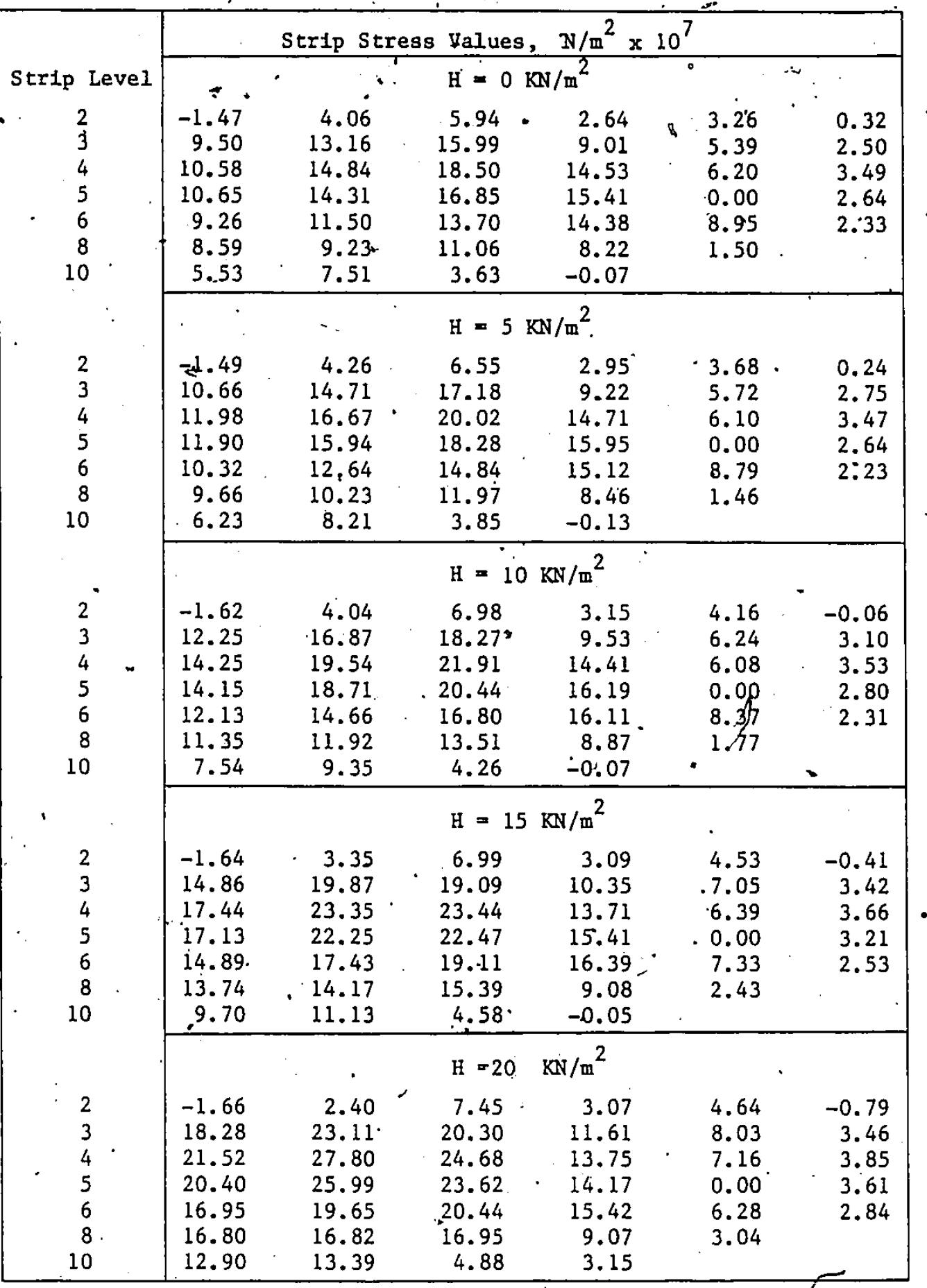


Table 4.6 Values of Strip Stress for Test no. $6, q=60 \mathrm{kN} / \mathrm{m}^{2}$; Load Location II; Load Towards the Wall.

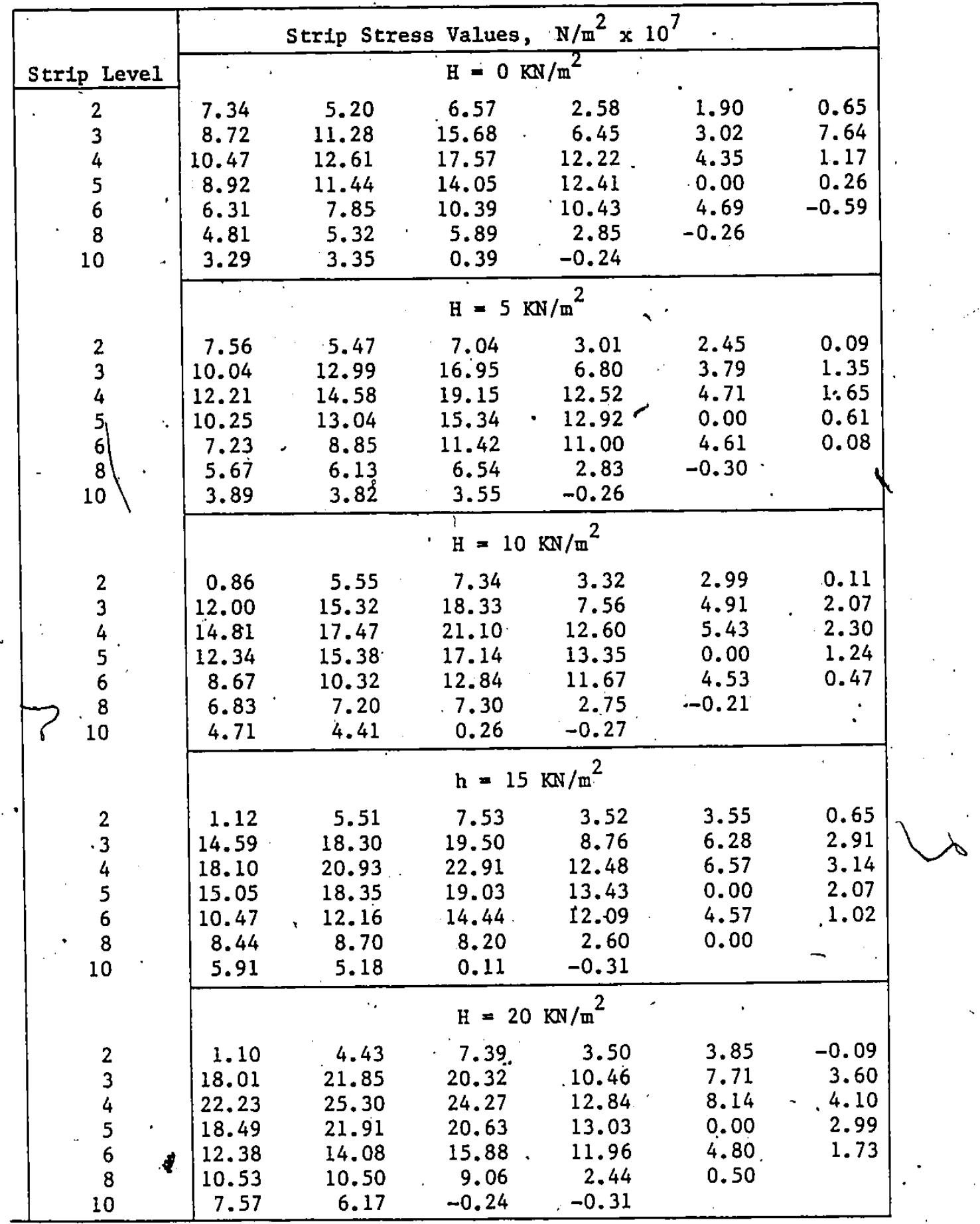



Table 4.8 Values of Strip Stress for Test no. $8, q=80 \mathrm{kN} / \mathrm{m}^{2}$; Load Location II; Load Towards the wall.

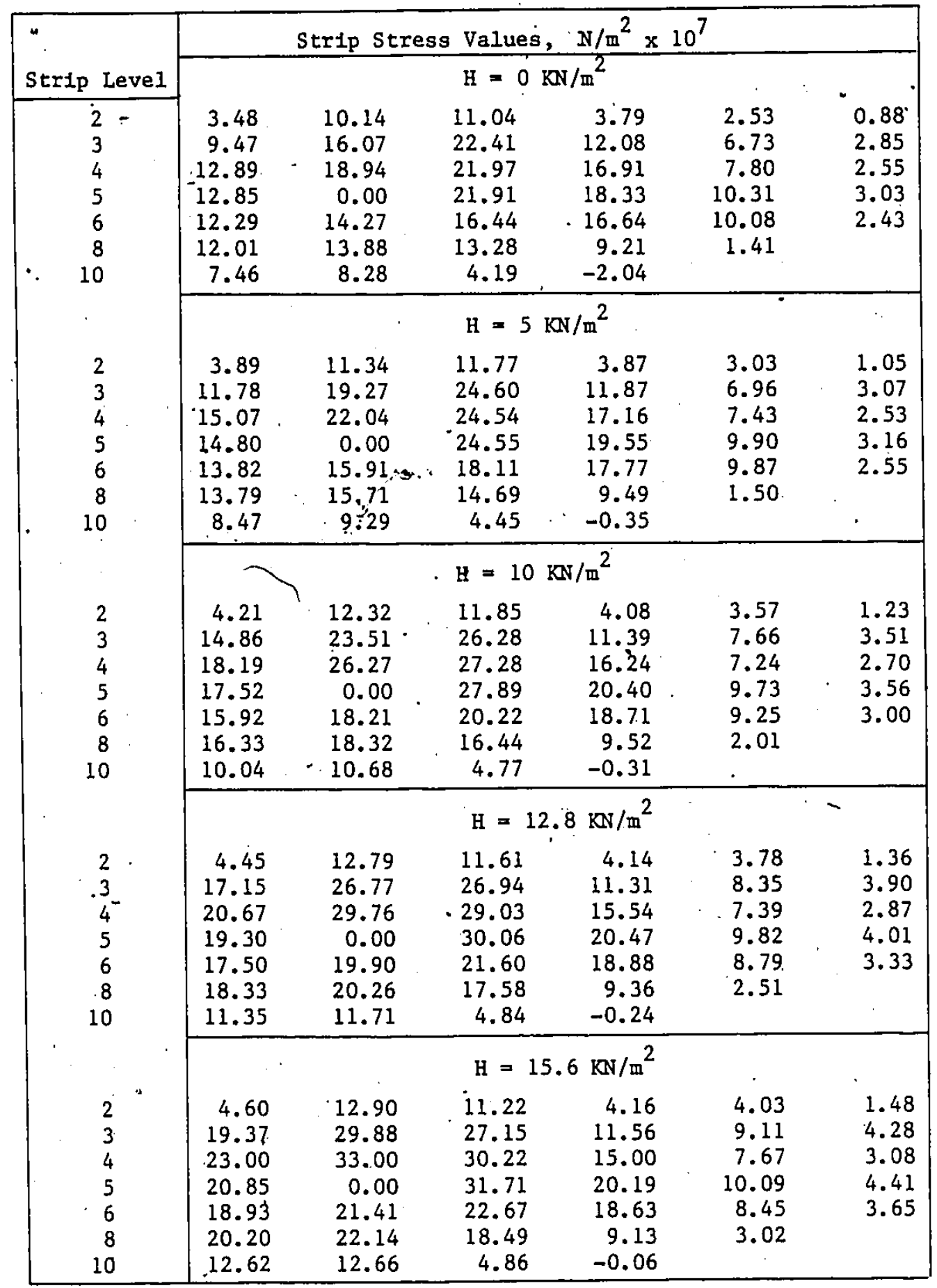


Table 4.9 Values of Strip Stress for Test no. $9, \cdots q=100 \mathrm{kN} / \mathrm{m}^{2}$; Load Location II; Load Away From the Wall Face.

\begin{tabular}{|c|c|c|c|c|c|c|}
\hline \multirow[b]{2}{*}{ Strip LeveI } & \multicolumn{6}{|c|}{ Strip Stress values, $/ \mathrm{N} / \mathrm{m}^{2} \times 10^{7}$} \\
\hline & \multirow[b]{2}{*}{$\begin{array}{r}1.60 \\
9.40 \\
16.53 \\
13.23 \\
13.82 \\
14.88 \\
11.82\end{array}$} & \multicolumn{4}{|c|}{$\mathrm{H}=0 \mathrm{KN} / \mathrm{m}^{2}$} & \multirow[b]{2}{*}{$\begin{array}{l}0.58 \\
2.41 \\
4.81 \\
4.20 \\
3.70\end{array}$} \\
\hline \multirow[t]{2}{*}{$\begin{array}{l}2 \\
3 \\
4 \\
5 \\
6 \\
8\end{array}$} & & $\begin{array}{r}5.01 \\
17.84 \\
0.00 \\
17.89 \\
18.91 \\
17.76 \\
12.77\end{array}$ & $\begin{array}{r}11.16 \\
30.41 \\
31.38 \\
25.21 \\
20.29 \\
19.13 \\
7.20\end{array}$ & $\begin{array}{r}2.68 \\
14.34 \\
25.67 \\
25.26 \\
22.15 \\
11.66 \\
0.31\end{array}$ & $\begin{array}{r}2.61 \\
8.56 \\
12.95 \\
0.00 \\
13.27 \\
1.82\end{array}$ & \\
\hline & \multicolumn{6}{|c|}{$\mathrm{H}=10 \mathrm{kN} / \mathrm{m}^{2}$} \\
\hline \multirow[t]{2}{*}{$\begin{array}{r}2 \\
3 \\
4 \\
5 \\
6 \\
8 \\
10\end{array}$} & $\begin{array}{r}1.88 \\
6.51 \\
12.73 \\
9.91 \\
12.31 \\
13.72 \\
10.83 \\
\end{array}$ & $\begin{array}{r}5.15 \\
12.99 \\
0.00 \\
13.99 \\
16.57 \\
16.68 \\
12.60 \\
\end{array}$ & $\begin{array}{r}12.79 \\
29.34 \\
28.90 \\
23.41 \\
19.32 \\
19.42 \\
7.97 \\
\end{array}$ & $\begin{array}{r}1.17 \\
10.47 \\
24.36 \\
25.36 \\
22.77 \\
12.80 \\
0.48 \\
\end{array}$ & $\begin{array}{r}0.75 \\
4.49 \\
10.06 \\
0.00 \\
13.36 \\
1.90\end{array}$ & $\begin{array}{r}-0.37 \\
-0.33 \\
3.11 \\
3.29 \\
3.31\end{array}$ \\
\hline & \multicolumn{5}{|c|}{$\mathrm{H}=20 \mathrm{KN} / \mathrm{m}^{2}}$. & $\theta$ \\
\hline \multirow[t]{3}{*}{$\begin{array}{c}2 \\
3 \\
4 \\
5 \\
6 \\
8 . \\
10\end{array}$} & $\begin{array}{r}3.52 \\
5.77 \\
8.88 \\
5.57 \\
9.29 \\
12.09 \\
9.57\end{array}$ & $\begin{array}{r}8.11 \\
10.70 \\
0.00 \\
8.66 \\
12.51 \\
14.88 \\
12.01\end{array}$ & $\begin{array}{r}17.77 \\
28.97 \\
23.60 \\
18.89 \\
16.04 \\
19.04 \\
8.77 \\
\end{array}$ & $\begin{array}{r}0.02 \\
6.92 \\
23.68 \\
25.21 \\
22.67 \\
14.27 \\
0.76 \\
\end{array}$ & $\begin{array}{r}-0.39 \\
0.49 \\
6.79 \\
0.00 \\
.13 .67 \\
2.00\end{array}$ & $\begin{array}{r}-1.01 \\
-2.67 \\
0.75 \\
1.99 \\
2.74\end{array}$ \\
\hline & & \multicolumn{2}{|c|}{$\mathrm{H}=30 \mathrm{KN} / \mathrm{m}^{2}$} & & \\
\hline & $\begin{array}{r}10.35 \\
8.75 \\
6.56 \\
3.24 \\
6.92 \\
11.08 \\
8.64\end{array}$ & $\begin{array}{r}17.78 \\
13.98 \\
0.00 \\
5.53 \\
9.44 \\
13.61 \\
11.37\end{array}$ & $\begin{array}{r}32.72 \\
32.08 \\
18.56 \\
15.03 \\
12.88 \\
18.49 \\
9.29\end{array}$ & $\begin{array}{r}-7.62 \\
: 4.28 \\
23.40 \\
25.19 \\
22.09 \\
15.40 \\
0.98\end{array}$ & $\begin{array}{r}1.09 \\
-8.68 \\
3.94 \\
0.00 \\
14.05 \\
2.19\end{array}$ & $\begin{array}{r}-1.05 \\
-3.84 \\
-1.23 \\
0.99 \\
2.47\end{array}$ \\
\hline
\end{tabular}


Table 4.10 Values of Strip Stress for Test no. $10, q=100 \mathrm{kN} / \mathrm{m}^{2}$;

Load Location II; Load Away From Wall Face.

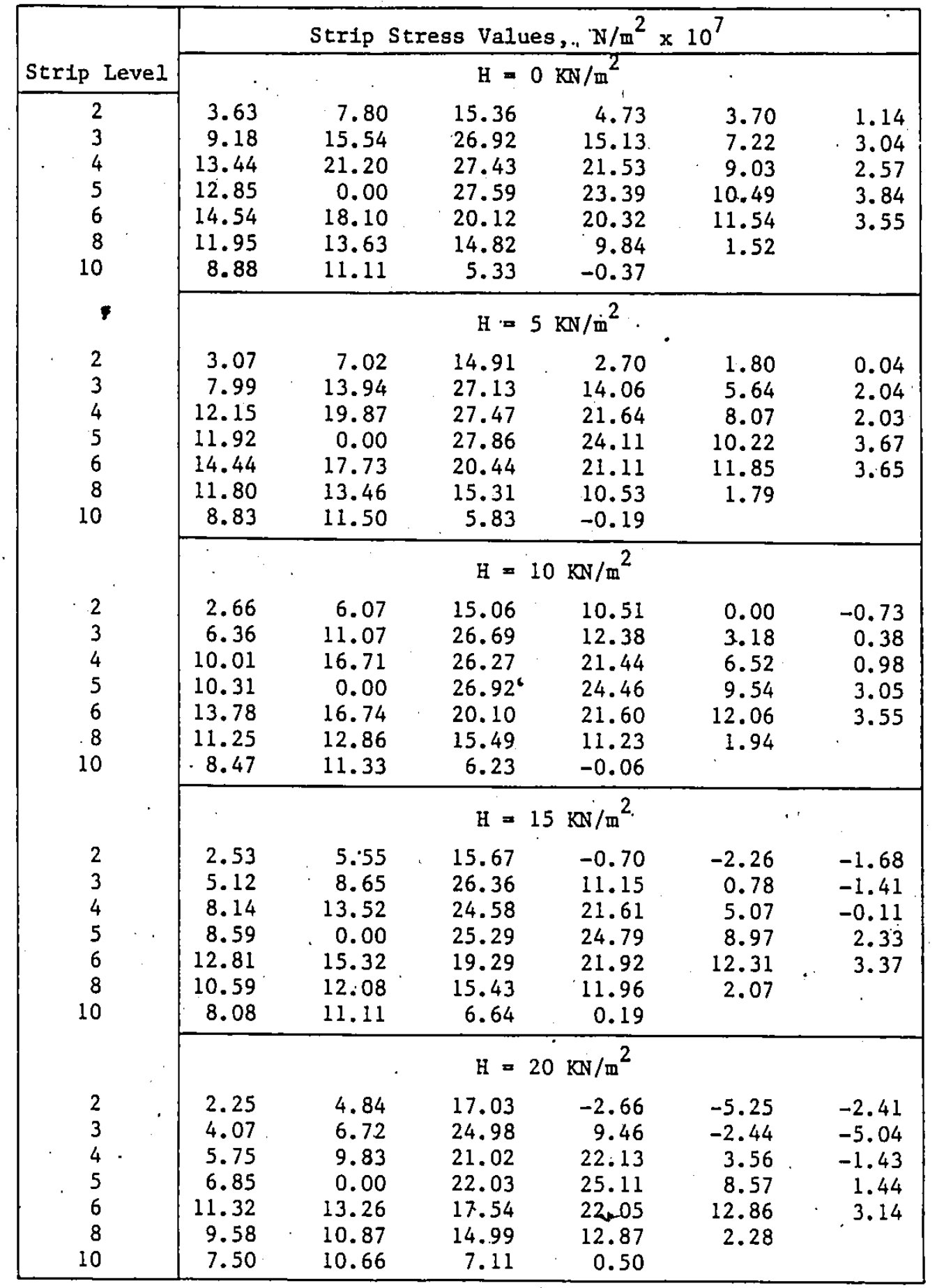


Table 4.11. Values of Strip Stress for Test no. $11, q=100 \mathrm{kN} / \mathrm{m}^{2}$; Load Location II; Load Towards the Wall Face.

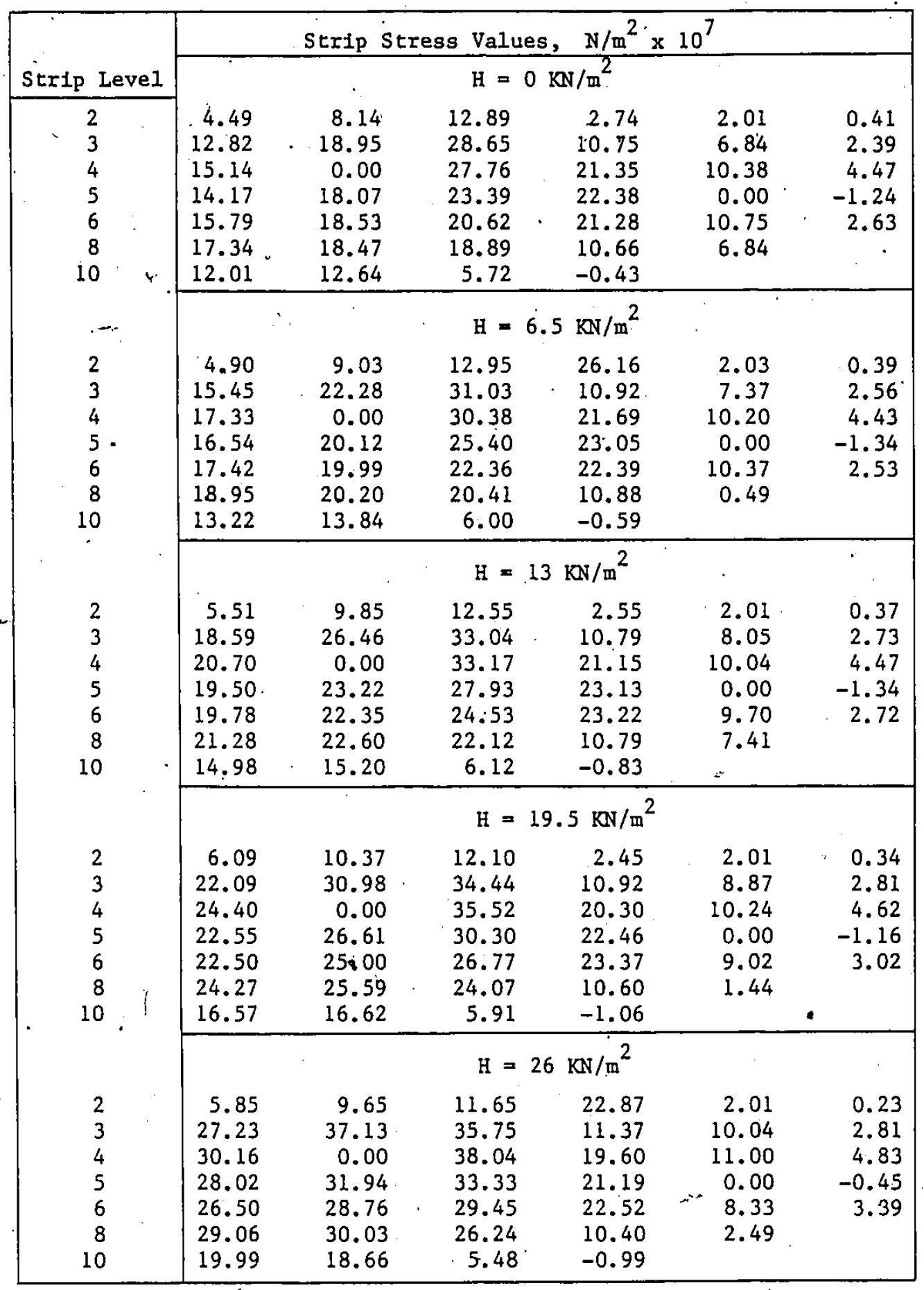




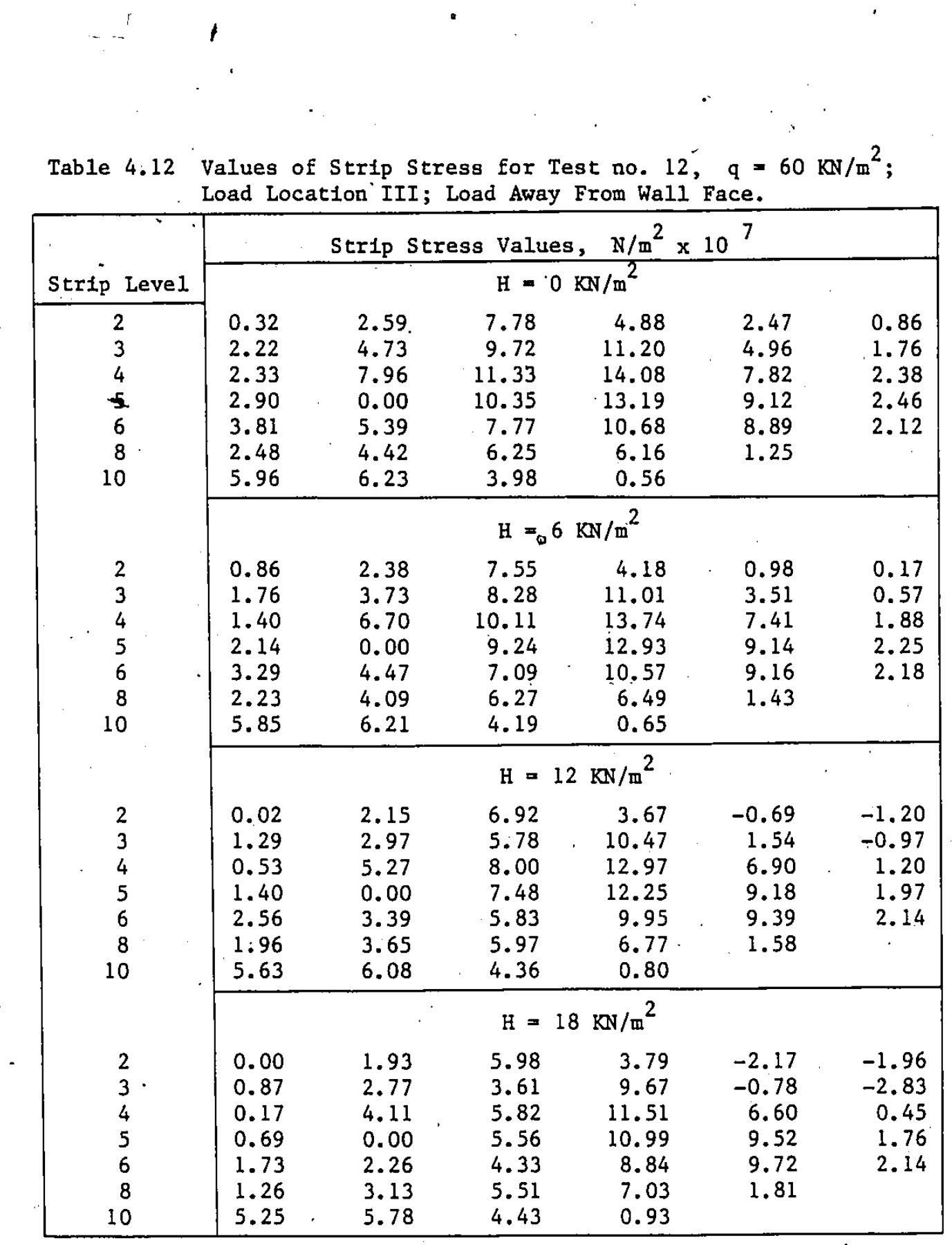


Table 4.13 Values of Strip Stress for Test no. 13, $q=60 \mathrm{kN} / \mathrm{m}^{2}$; Load Location III; Load Towards Wall Face.

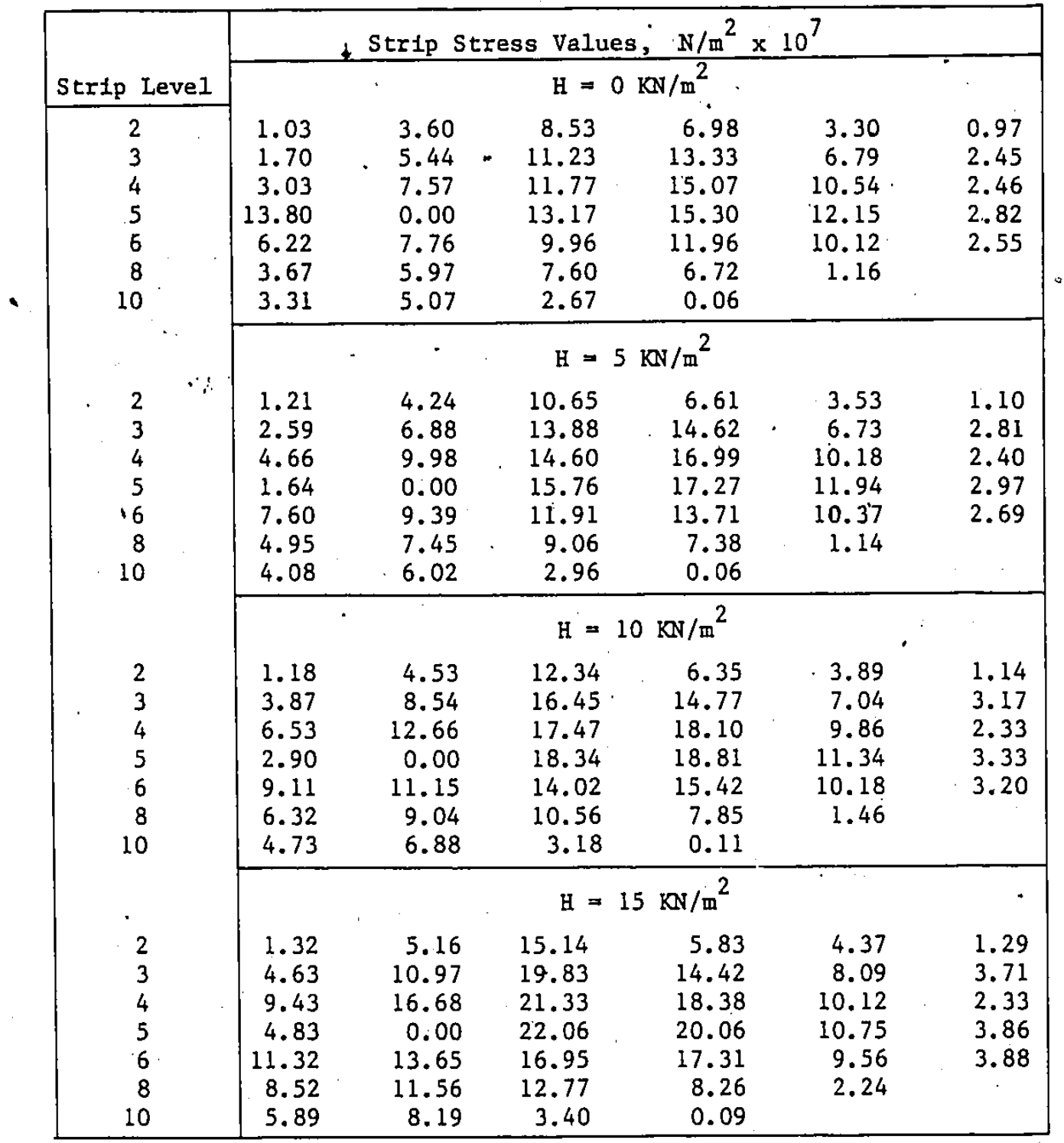


Table 4.14 Values of Strip Stress for Test no. $14, q=100 \mathrm{kN} / \mathrm{m}^{2}$; Load Location III; Load Away From Wall Face..

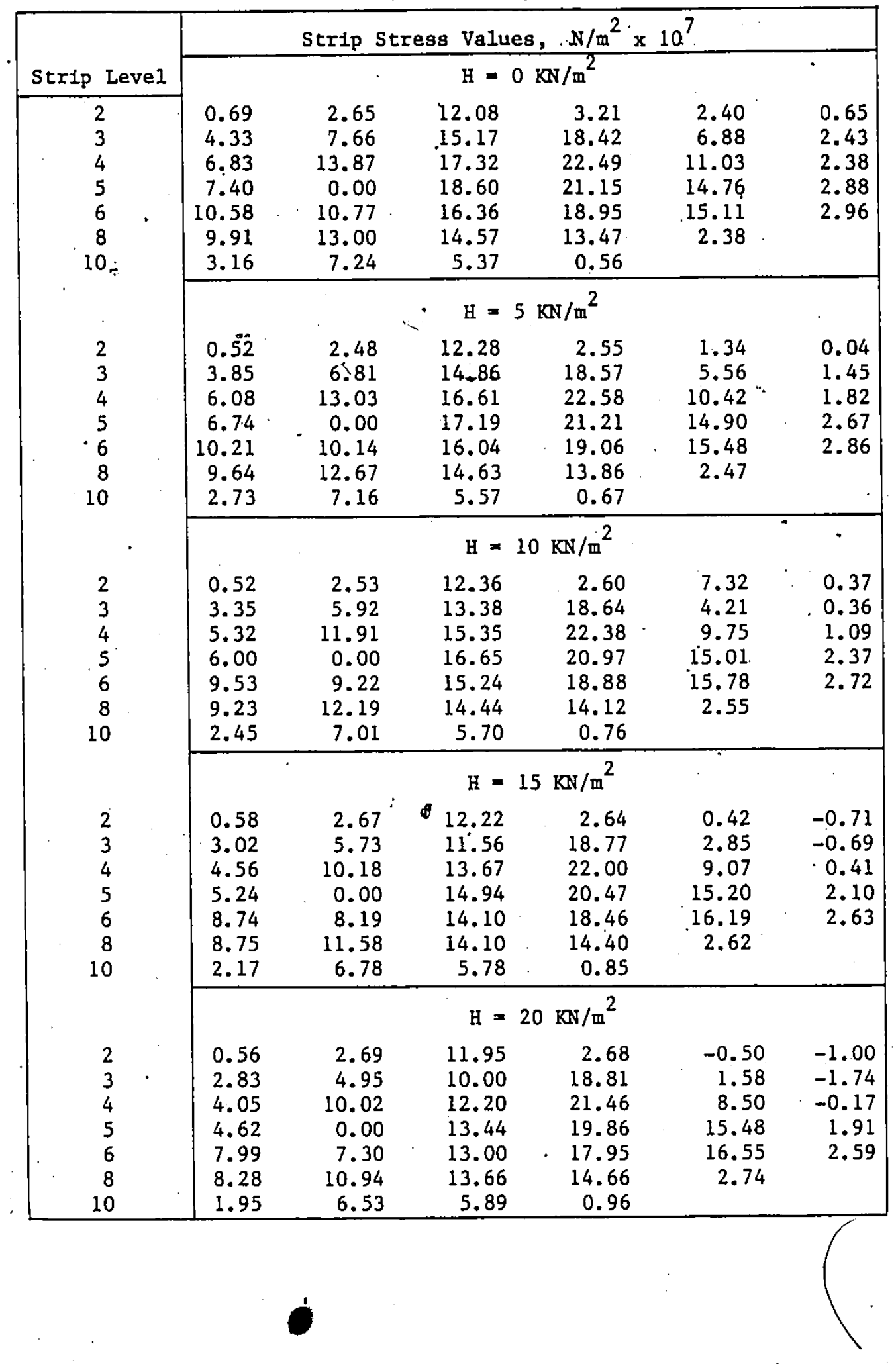


Table 4.14 (cont.) Values of Strip Stress for Test no. $14, q=100 \mathrm{kN} / \mathrm{m}^{2}$; Load Location .IEI; Load Away From Wall Face.

\begin{tabular}{|c|rrrrrr|}
\hline & \multicolumn{5}{|c|}{ Strip Stress Vaiues, $\mathrm{N} / \mathrm{m}^{2} \times 10^{7}$} \\
\cline { 3 - 7 } Str1p Leve1 & \multicolumn{5}{|c|}{$\mathrm{H}=23.25 \mathrm{kN} / \mathrm{m}^{2}$} \\
\cline { 3 - 7 } & 7.13 & 2.96 & 11.63 & 3.30 & -0.86 & -1.14 \\
3 & 2.79 & 4.82 & 7.97 & 18.96 & -0.37 & -3.40 \\
4 & 3.24 & 9.12 & 10.17 & 20.46 & 7.73 & -0.98 \\
5 & 4.00 & 0.00 & 11.49 & 18.92 & 16.01 & 1.65 \\
6 & 7.07 & 6.20 & 11.50 & 17.13 & 17.20 & 2.53 \\
8 & 7.61 & 10.06 & 12.94 & 14.94 & 2.85 & \\
10 & 1.61 & 6.17 & 5.97 & 1.11 & & \\
\hline
\end{tabular}


Table 4.15 Values of Strip Stress for Test no. $15, q=100 \mathrm{KN} / \mathrm{m}^{2}$; Load Location III; Load Towards Wall Face.

\begin{tabular}{|c|c|c|c|c|c|c|}
\hline \multirow{2}{*}{ Strip Level } & \multicolumn{6}{|c|}{ Strip Stress Values, $\mathrm{N} / \mathrm{m}^{2} \times 10^{7}$} \\
\hline & & & $\mathrm{H}=$ & $\mathrm{KN} / \mathrm{m}^{2}$ & & \\
\hline \multirow[t]{2}{*}{$\begin{array}{r}2 \\
3 \\
4 \\
5 \\
6 \\
8 \\
10\end{array}$} & $\begin{array}{r}1.12 \\
7.23 \\
11.21 \\
11.14 \\
3.83 \\
0.00 \\
6.50\end{array}$ & $\begin{array}{r}4.12 \\
10.65 \\
15.22 \\
0.00 \\
8.71 \\
10.37 \\
7.48\end{array}$ & $\begin{array}{r}17.97 \\
21.95 \\
20.53 \\
23.00 \\
12.62 \\
12.29 \\
3.80\end{array}$ & $\begin{array}{r}6.47 \\
20.76 \\
24.05 \\
25.22 \\
16.94 \\
11.22 \\
0.15\end{array}$ & $\begin{array}{r}3.53 \\
5.73 \\
9.27 \\
1.40 \\
14.15 \\
1.94\end{array}$ & $\begin{array}{l}0.60 \\
1.66 \\
1.84 \\
2.50 \\
2.80\end{array}$ \\
\hline & \multicolumn{6}{|c|}{$\mathrm{H}=5 \mathrm{KN} / \mathrm{m}^{2}$} \\
\hline $\begin{array}{r}2 \\
3 \\
4 \\
5 \\
6 \\
8 \\
10\end{array}$ & $\begin{array}{r}1.17 \\
7.96 \\
12.38 \\
12.35 \\
4.40 \\
0.00 \\
7.11\end{array}$ & $\begin{array}{r}4.43 \\
11.59 \\
16.90 \\
0.00 \\
9.60 \\
11.14 \\
8.08\end{array}$ & $\begin{array}{r}19.32 \\
23.88 \\
22.70 \\
25.22 \\
13.82 \\
13.13 \\
3.95 \\
\end{array}$ & $\begin{array}{r}6.82 \\
21.43 \\
25.81 \\
26.88 \\
18.16 \\
11.59 \\
0.09\end{array}$ & $\begin{array}{r}3.93 \\
5.75 \\
8.88 \\
14.03 \\
14.40 \\
1.81\end{array}$ & $\begin{array}{l}0.77 \\
1.97 \\
2.01 \\
2.67 \\
2.69 \\
\end{array}$ \\
\hline & \multicolumn{6}{|c|}{$\mathrm{H}=10 \mathrm{kN} / \mathrm{m}^{2}$} \\
\hline $\begin{array}{r}2 \\
3 \\
4 \\
5 \\
6 \\
8 \\
10\end{array}$ & $\begin{array}{r}1.27 \\
9.03 \\
13.97 \\
14.18 \\
5.28 \\
0.00 \\
7.95\end{array}$ & $\begin{array}{r}4.84 \\
13.03 \\
19.05 \\
0.00 \\
10.96 \\
12.29 \\
8.83\end{array}$ & $\begin{array}{r}20.71 \\
26.32 \\
25.38 \\
28.38 \\
15.58 \\
14.31 \\
4.15\end{array}$ & $\begin{array}{r}6.57 \\
21.13 \\
27.18 \\
29.04 \\
19.83 \\
12.03 \\
0.11\end{array}$ & $\begin{array}{r}4.37 \\
5.79 \\
8.24 \\
13.65 \\
14.36 \\
1.75\end{array}$ & $\begin{array}{l}0.95 \\
2.31 \\
2.25 \\
3.05 \\
2.74\end{array}$ \\
\hline 10 & \multicolumn{6}{|c|}{$\mathrm{H}=15 \mathrm{kN} / \mathrm{m}^{2}$. } \\
\hline \multirow[t]{2}{*}{$\begin{array}{r}2 \\
3 \\
4 \\
5 \\
6 \\
8 \\
10\end{array}$} & $\begin{array}{r}1.27 \\
10.27 \\
16.37 \\
17.09 \\
6.72 \\
0.00 \\
7.13\end{array}$ & $\begin{array}{r}5.38 \\
14.94 \\
22.19 \\
0.00 \\
13.11 \\
14.28 \\
9.18\end{array}$ & $\begin{array}{r}22.50 \\
29.59 \\
29.01 \\
32.95 \\
18.26 \\
16.15 \\
4.04\end{array}$ & $\begin{array}{r}5.89 \\
19.62 \\
27.69 \\
31.44 \\
22.11 \\
12.31 \\
0.07\end{array}$ & $\begin{array}{r}4.62 \\
6.36 \\
7.88 \\
13.12 \\
13.90 \\
1.82\end{array}$ & $\begin{array}{l}1.18 \\
2.73 \\
2.57 \\
3.63 \\
3.00\end{array}$ \\
\hline & 0 & \multicolumn{5}{|c|}{$\mathrm{H}=17.6 \mathrm{KN} / \mathrm{m}^{2}$} \\
\hline $\begin{array}{r}2 \\
3 \\
4 \\
5 \\
6 \\
8 \\
10\end{array}$ & $\begin{array}{r}1.45 \\
11.47 \\
18.34 \\
19.30 \\
7.78 \\
0.00 \\
8.47\end{array}$ & $\begin{array}{r}6.06 \\
16.73 \\
24.60 \\
0.00 \\
14.64 \\
15.40 \\
9.95\end{array}$ & $\begin{array}{r}24.46 \\
31.97 \\
31.63 \\
36.16 \\
20.03 \\
17.14 \\
4.15\end{array}$ & $\begin{array}{r}5.38 \\
18.51 \\
27.24 \\
32.61 \\
23.31 \\
12.35 \\
0.13\end{array}$ & $\begin{array}{r}4.56 \\
7.06 \\
7.90 \\
12.91 \\
13.40 \\
2.01\end{array}$ & $\begin{array}{l}1.33 \\
3.10 \\
2.80 \\
4.01 \\
3.18\end{array}$ \\
\hline
\end{tabular}


Table 4.16 Values of Strip Stress for Test no. $16, q=60 \mathrm{kN} / \mathrm{m}^{2}$; Load Location IV; Load Away From Wall Face.

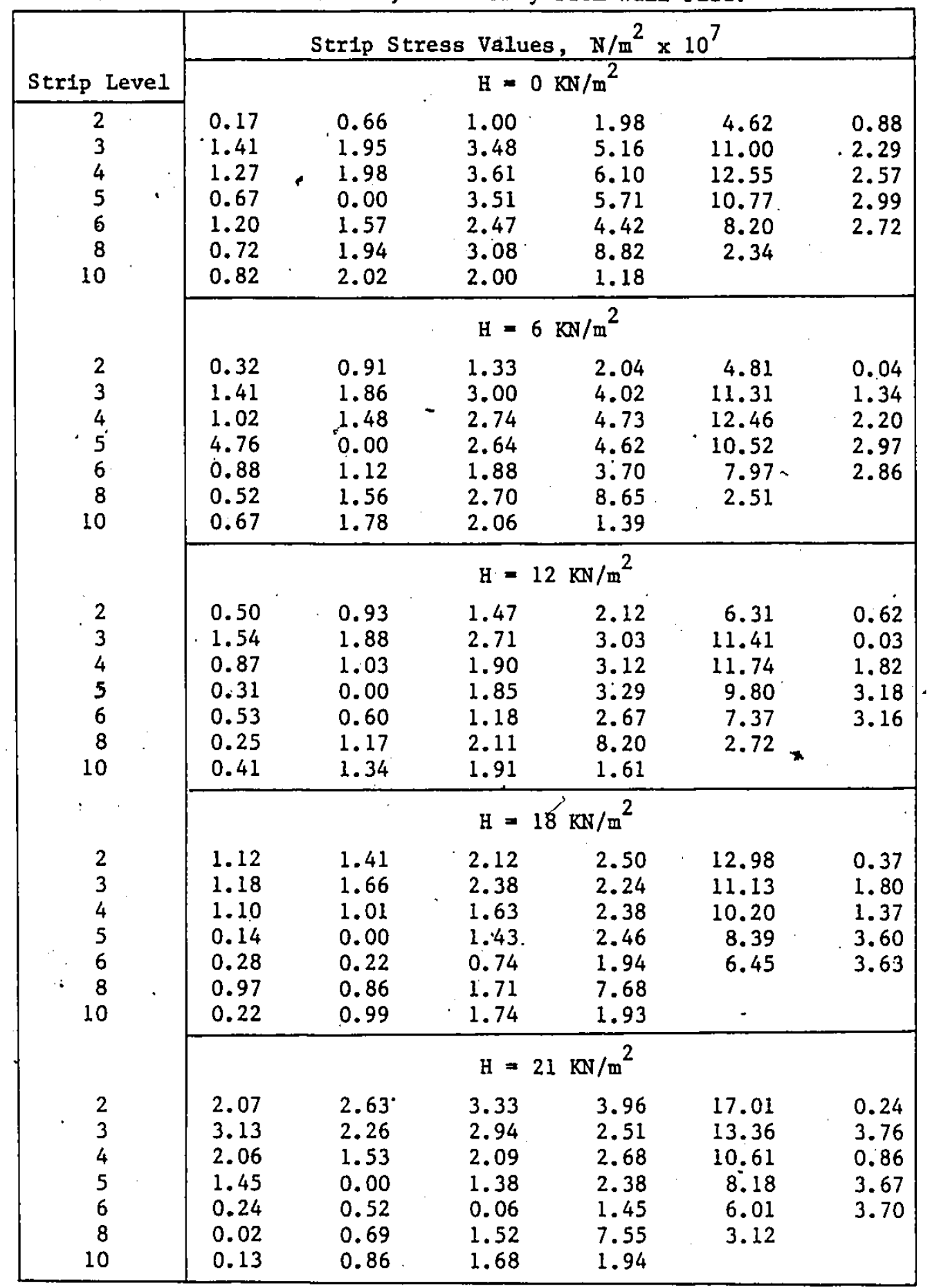




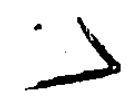

200

Table 4.17 Values of Strip Stress for Test no. 17, $q=60 \mathrm{kn} / \mathrm{m}^{2}$; Load Location IV; Load Towards Wall Face.

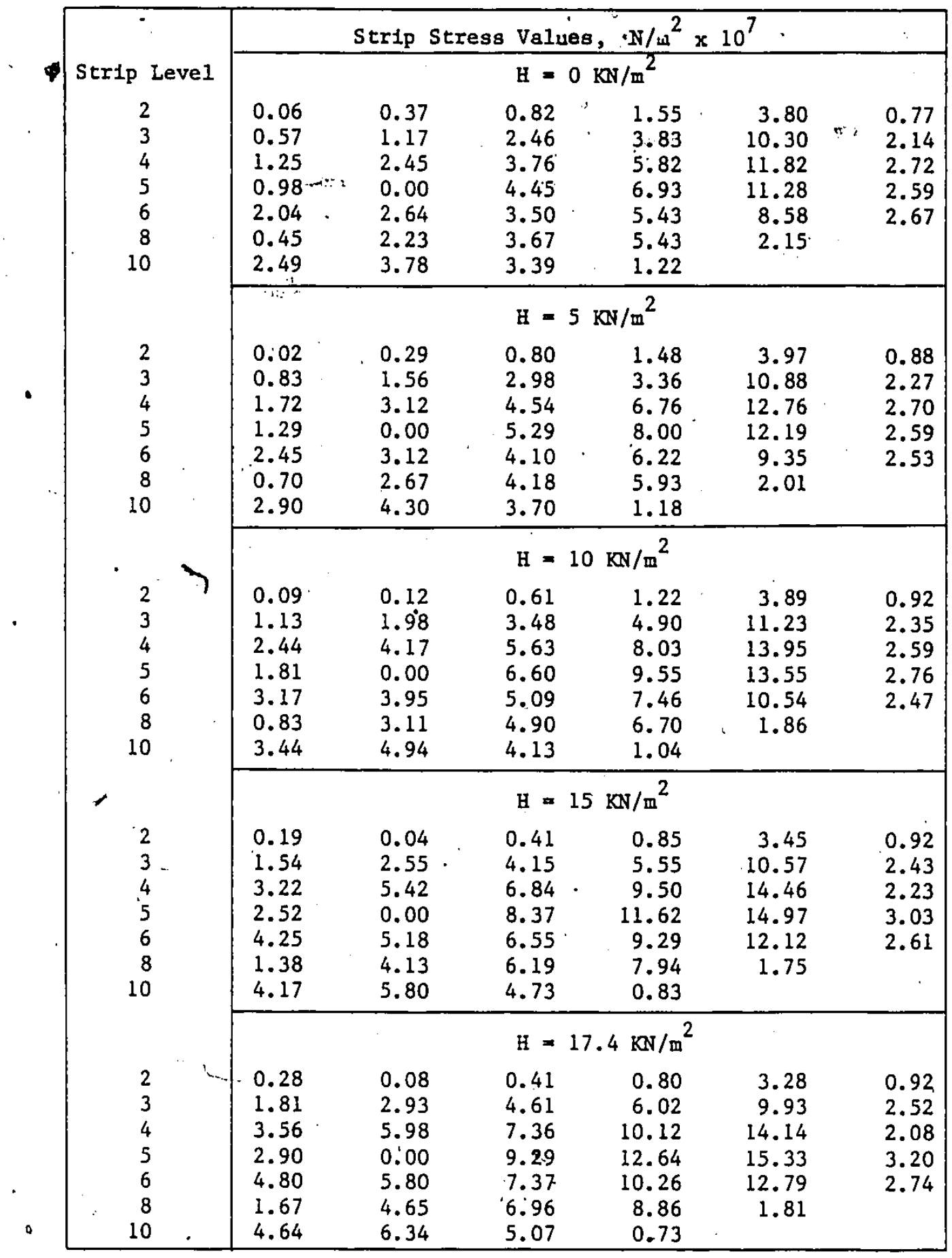


Table 4.18 Values of Strip Stress for Test no. $18, q=100 \mathrm{kN} / \mathrm{m}^{2}$; Load Locatjon IV; - Zoad-Away From Wall Face.

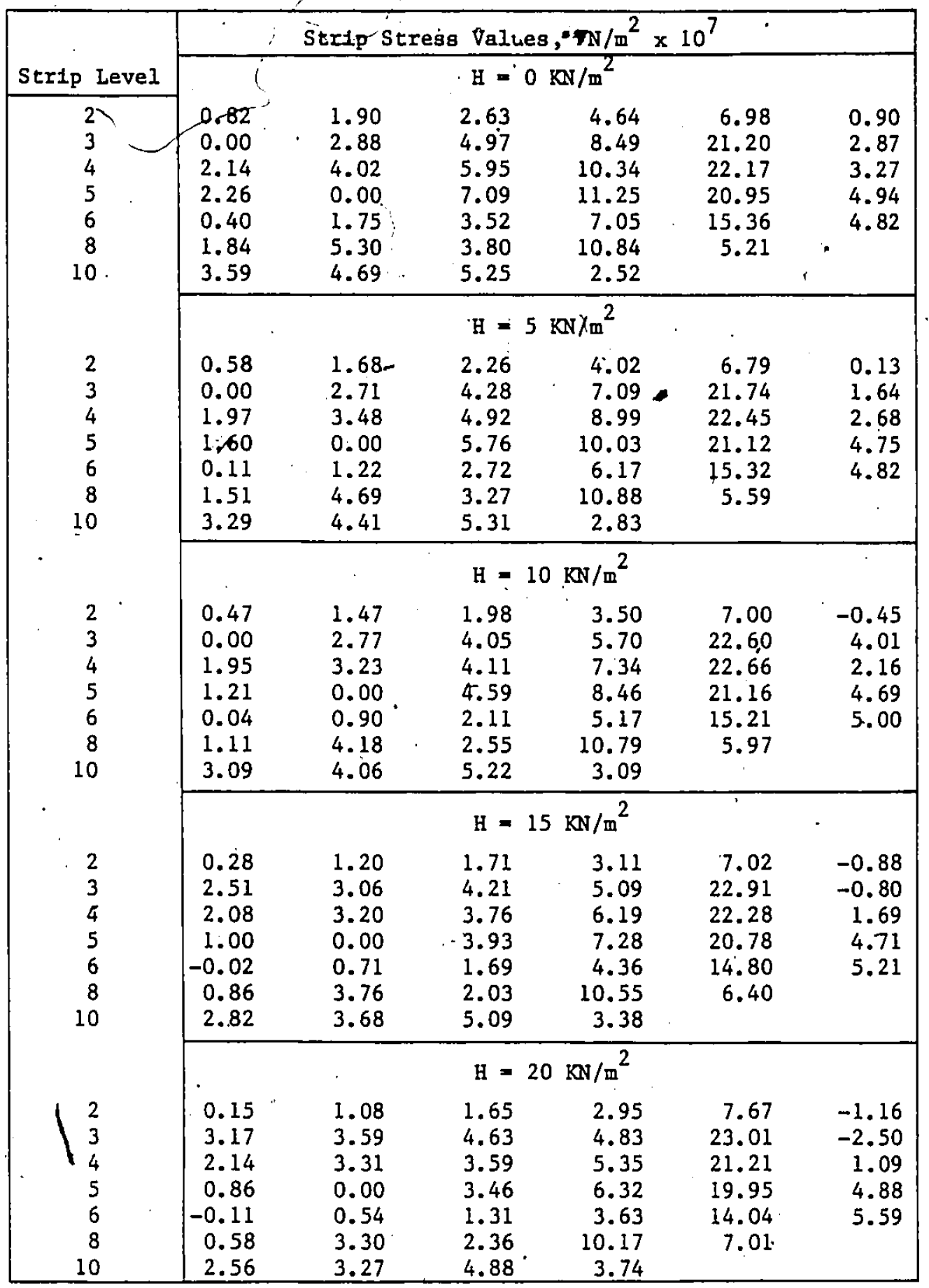


Table 4.19 Values of Strip stress for Test no. 19, $q=100 \mathrm{kN} / \mathrm{m}^{2}$; Load Location IV; Load Towards Wall Face.

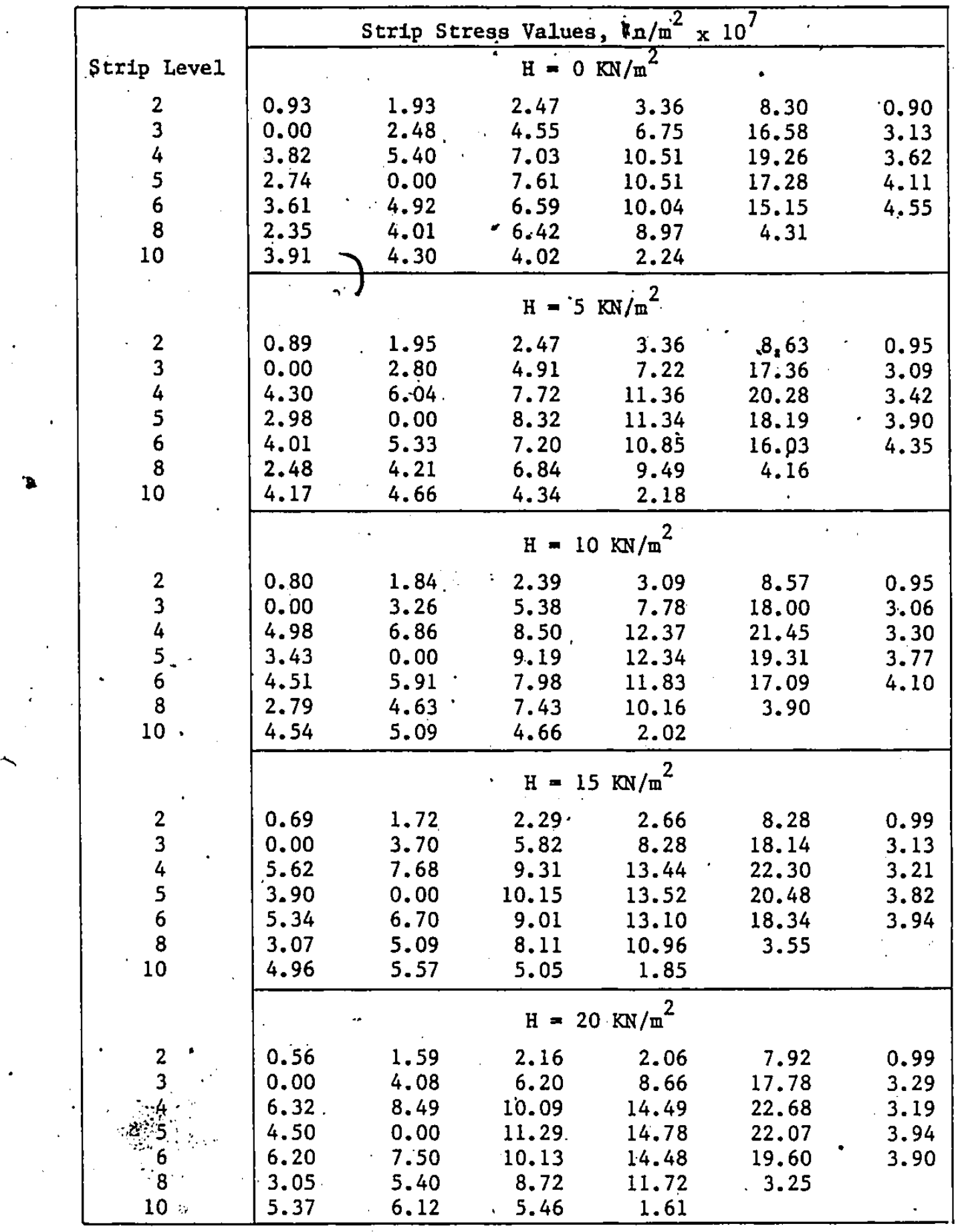




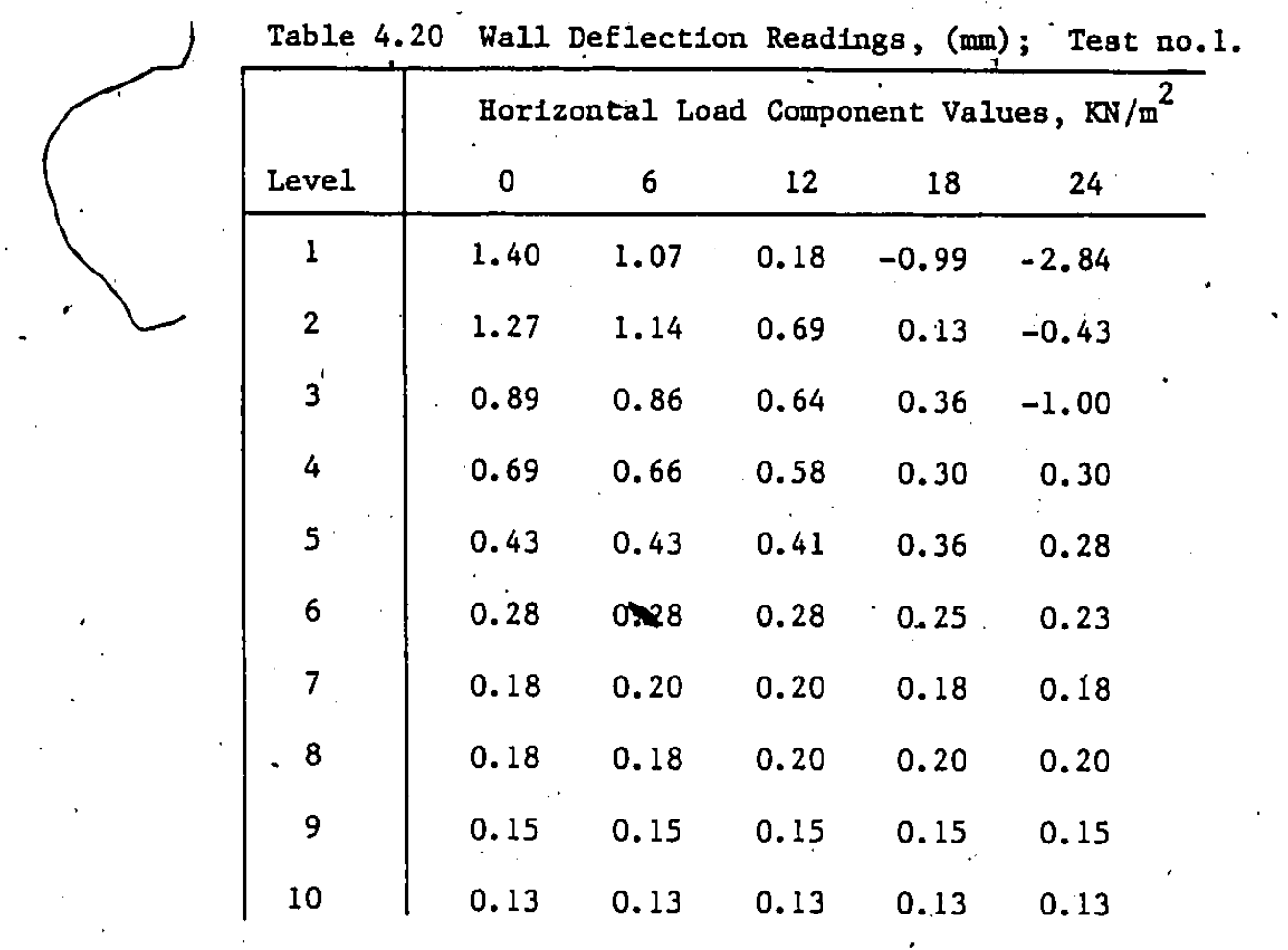

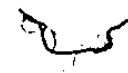

Table 4.21 Wall Deflection Readings, (mm); Test no.2.

\begin{tabular}{|c|ccc}
\hline & \multicolumn{3}{|c}{ Horlzọntal Load Component Values, $\mathrm{KN} / \mathrm{m}^{2}$} \\
\hline Leve1 & 0 & 5 & 10 \\
\hline 1 & 2.01 & 2.69 & 4.37 \\
2 & 1.73 & 2.26 & 3.56 \\
3 & 1.22 & 1.57 & 2.44 \\
4 & 0.76 & 0.99 & 1.45 \\
5 & 0.51 & 0.64 & 0.91 \\
6 & 0.33 & 0.41 & 0.56 \\
7 & 0.23 & 0.28 & 0.41 \\
8 & 0.20 & 0.25 & 0.33 \\
9 & 0.18 & 0.23 & 0.28 \\
10 & 0.10 & 0.13 & 0.15
\end{tabular}

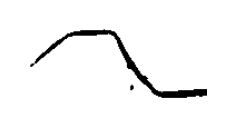




\begin{tabular}{|c|c|c|c|c|c|c|}
\hline Level & $\begin{array}{c}\text { Hort2 } \\
0\end{array}$ & $\begin{array}{c}\text { zontal Loa } \\
\qquad 3\end{array}$ & $\begin{array}{c}\text { ad Compo } \\
6\end{array}$ & $\begin{array}{c}\text { ient } \mathrm{Val} \\
9\end{array}$ & $\begin{array}{c}\text { ses, } \mathrm{KN} / \mathrm{m}^{2} \\
12\end{array}$ & 15 \\
\hline 1 & 2.24 & 2.21 & 2.03 & 1.80 & 1.50 & 1.12 \\
\hline 2 & 1.75 & 1.73 & 1.63 & 1.50 & 1.35 & 1.14 \\
\hline 3 & 1.36 & 1.32 & 1.30 & 1.22 & 1.14 & 1.04 \\
\hline 4 & 0.91 & 0.91 & 0.91 & 0.89 & 0.86 & 0.81 \\
\hline 5 & 0.70 & 0.70 & 0.70 & 0.69 & 0.69 & 0.69 \\
\hline 6 & 0.48 & 0.48 & 0.51 & 0.51 & $0.51-$ & 0.51 \\
\hline$i$ & 0.41 & 0.41 & 0.41 & 0.41 & 0.41 & 0.41 \\
\hline 8 & 0.43 & 0.43 & 0.43 & 0.43 & 0.43 & 0.43 \\
\hline 9 & 0.25 & 0.25 & 0.25 & 0.25 & 0.25 & 0.25 \\
\hline \multirow[t]{2}{*}{10} & 0.15 & 0.15 & 0.15 & -0.15 & 0.15 & 0.13 \\
\hline & $i$ & & & & ' & \\
\hline
\end{tabular}

Table 4.23 Wall Deflection Readings, $4(\mathrm{~mm})$; Test no. 4.

\begin{tabular}{|c|cccc}
\hline & \multicolumn{3}{|c}{ Horizontal Load Component Values, $\mathrm{KN} / \mathrm{m}^{2}$} \\
Level & 0 & 7 & 14 & 21 \\
\hline 1. & 0.28 & -0.56 & -1.40 & -3.38 \\
2 & 0.66 & 0.51 & 0.20 & -0.66 \\
3 & 0.76 & 0.71 & 0.58 & 0.48 \\
4 & 0.51 & 0.48 & 0.43 & 0.41 \\
5 & 0.48 & 0.48 & 0.43 & 0.41 \\
6 & 0.33 & 0.33 & 0.33 & 0.33 \\
7 & 0.33 & 0.33 & 0.33 & 0.33 \\
8 & 0.30 & 0.30 & 0.30 & 0.30 \\
9 & 0.18 & 0.18 & 0.18 & 0.18 \\
10 & 0.20 & 0.20 & 0.20 & 0.20 \\
\hline
\end{tabular}


Table 4.24 Wall Deflection Readings, (mm); Test no.5.

\begin{tabular}{|c|ccccc}
\hline \multirow{2}{*}{ Leve1 } & \multicolumn{5}{|c}{ Horizontal Load Component Values, KN $\mathrm{m}^{2}$} \\
\hline 1 & 0 & 7 & 14 & 21 & 28 \\
\hline 2 & 0.36 & 0.51 & 0.99 & 1.98 & 3.68 \\
3 & 0.64 & 0.79 & 1.14 & 1.93 & 3.28 \\
4 & 0.69 & 0.79 & 1.12 & 1.70 & 2.72 \\
5 & 0.56 & 0.64 & 0.81 & 1.22 & 1.91 \\
6 & 0.51 & 0.58 & 0.71 & 0.99 & 1.45 \\
7 & 0.38 & 0.41 & 0.51 & 0.69 & 0.99 \\
8 & 0.36 & 0.38 & 0.46 & 0.58 & 0.81 \\
9 & 0.36 & 0.38 & 0.43 & 0.53 & 0.71 \\
10 & 0.23 & 0.25 & 0.30 & 0.38 & 0.48
\end{tabular}

\begin{tabular}{|c|c|c|c|c|c|}
\hline Level & $\begin{array}{l}\text { Hort } \\
0 \\
\end{array}$ & $\begin{array}{l}\text { Intal Loa } \\
\quad 5 \\
\end{array}$ & $\begin{array}{c}\text { Compo } \\
10 \\
\end{array}$ & $\begin{array}{r}.15 \\
.15 \\
\end{array}$ & $\begin{array}{l}\text { ies, } \mathrm{kN} / \mathrm{m}^{2} \\
20 \\
\end{array}$ \\
\hline 1 & 0.03 & 0.05 & 0.23 & 0.58 & 1.22 \\
\hline 2 & 0.20 & 0.28 & 0.30 & 0.74 & 1.27 \\
\hline 3 & 0.18 & 0.05 & $0.36^{\circ}$ & $0.56^{-}$ & 0.91 \\
\hline 4 & $\theta .15$ & 0.20 & 0.28 & 0.41 & .0 .64 \\
\hline 5 & 0.10 & 0.13 & 0.18 & 0.25 & 0.38 \\
\hline 6 & 0.08 & 0.10 & 0.13 & $0: 18$ & 0.25 \\
\hline 7 & 0.05 & 0.05 & 0.08 & 0.10 & 0.15 \\
\hline 8 & 0.03 & 0.05 & 0.05 & 0.08 & 0.10 \\
\hline 9 & 0.03 & 0.03 & 0.03 & 0.05 & 0.08 \\
\hline 10 & 0.03 & 0.03 & 0.03 & 0.03 & 0.05 \\
\hline
\end{tabular}


Table 4.26. Wall Deflection Readings, (mm); Test no.8.

\begin{tabular}{|c|ccccc}
\hline & \multicolumn{6}{|c}{ Horizont,al Load Component Values, $\mathrm{KN} / \mathrm{m}^{2}$} \\
Level & 0 & 5 & 10 & 12.8 & 15.6 \\
\hline 1 & 0.61 & 0.84 & 1.32 & 1.83 & 2.46 \\
2 & 0.79 & 0.97 & 1.98 & 1.75 & 2.18 \\
3 & 0.71 & 0.64 & 1.17 & 1.50 & 1.85 \\
4 & 0.64 & 0.74 & 0.94 & 1.17 & 1.40 \\
5 & 0.48 & 0.56 & 0.69 & 0.84 & 1.02 \\
6 & 0.43 & 0.48 & 0.58 & 0.69 & 0.76 \\
7 & 0.36 & 0.41 & 0.48 & 0.56 & 0.64 \\
8 & 0.30 & 0.36 & 0.41 & 0.48 & 0.53 \\
9 & 0.20 & 0.25 & 0.28 & 0.30 & 0.33 \\
10 & 0.20 & 0.23 & 0.25 & 0.30 & 0.33 \\
\hline
\end{tabular}

Table 4.27 Wall Deflection Readings, (ma); Test no.9.

\begin{tabular}{|c|cccc}
\hline & \multicolumn{4}{|c}{ Horlzontal Load Component Values, $\mathrm{KN} / \mathrm{m}^{2}$} \\
Leve1 & 0 & 10 & 20 & 30 \\
\hline 1 & 1.19 & 0.69 & 0.36 & -0.84 \\
2 & 1.40 & 1.07 & 0.48 & -0.76 \\
3 & 1.34 & 1.19 & 0.86 & 0.36 \\
4 & 1.14 & 1.04 & 0.79 & 0.66 \\
5 & 0.97 & 0.97 & 0.86 & 0.79 \\
6 & 0.71 & 0.69 & 0.66 & 0.66 \\
7 & 0.71 & 0.71 & 0.71 & 0.71 \\
8 & 0.51 & 0.53 & 0.53 & 0.51 \\
9 & 0.38 & 0.38 & 0.38 & 0.41 \\
10 & 0.38 & 0.38 & 0.38 & 0.41
\end{tabular}


Table 4.28 Wall Deflection Readings, (mm); Test no.10.

\begin{tabular}{|c|ccccc}
\hline \multirow{2}{*}{ Leve1 } & \multicolumn{6}{|c}{ Horlzontal Load Component Values, KN $/ \mathrm{m}^{2}$} \\
\hline 1 & 0 & 5 & 10 & 15 & 20 \\
\hline 2 & 0.64 & 0.51 & 0.25 & -0.10 & -0.71 \\
3 & 0.84 & 0.76 & 0.61 & 0.41 & 0.03 \\
4 & 0.84 & 0.81 & 0.71 & 0.56 & 0.38 \\
5 & 0.76 & 0.79 & 0.74 & 0.66 & 0.53 \\
6 & 0.64 & 0.66 & 0.64 & 0.58 & 0.53 \\
7 & 0.48 & 0.53 & 0.53 & 0.51 & 0.51 \\
8 & 0.51 & 0.53 & 0.53 & 0.53 & 0.53 \\
9 & 0.46 & 0.48 & 0.48 & 0.51 & 0.51 \\
10 & 0.25 & 0.28 & 0.28 & 0.28 & 0.28 \\
& 0.15 & 0.18 & 0.18 & 0.18 & 0.18 \\
\hline
\end{tabular}

Table 4.29 Wall Deflection Readings, (mm); Test no.11.

\begin{tabular}{|c|ccccc}
\hline \multirow{2}{*}{ Leve1 } & \multicolumn{5}{|c}{ Horlzontal Load Component Values, KN $/ \mathrm{m}^{2}$} \\
\hline 1 & 0 & 6.5 & 13 & 19.5 & 26 \\
\hline 2 & 0.79 & 1.02 & 1.45 & 2.16 & 3.58 \\
3 & 0.84 & 1.02 & 1.40 & 2.01 & 3.20 \\
4 & 0.84 & 0.99 & 1.27 & 1.73 & 2.62 \\
5 & 0.64 & 0.71 & 0.91 & 1.22 & 1.85 \\
6 & 0.53 & 0.61 & 0.74 & 0.97 & 1.40 \\
7 & 0.38 & 0.43 & 0.51 & 0.66 & 1.09 \\
8 & 0.30 & 0.36 & 0.41 & 0.51 & 0.71 \\
9 & 0.28 & 0.30 & 0.36 & 0.43 & 0.58 \\
10 & 0.18 & 0.20 & 0.23 & 0.28 & 0.33 \\
& 0.08 & 0.08 & 0.10 & 0.10 & 0.13 \\
\hline
\end{tabular}


Table 4.30 Wall Deflection Readings, (mim); Test no.12.

\begin{tabular}{|c|c|c|c|c|c|}
\hline Level & $\begin{array}{c}\text { Hort } \\
0 \\
\end{array}$ & $\begin{array}{c}\text { ntal L } \\
6 \\
\end{array}$ & $\begin{array}{r}\text { Comp } \\
12 \\
\end{array}$ & $\begin{array}{c}\text { nent Values, } \\
18 \\
\end{array}$ & $\mathrm{KN} / \mathrm{m}$ \\
\hline 1 & 0.38 & 0.28 & 0.03 & -0.43 & \\
\hline $2^{\circ}$ & 0.48 & 0.66 & 0.25 & 0.03 & \\
\hline 3 & 0.51 & .0 .48 & 0.28 & 0.30 & \\
\hline 4 & 0.46 & 0.48 & 0.43 & 0.36 & \\
\hline 5 & 0.43 & 0.46 & 0.43 & 0.66 & . \\
\hline 6 & 0.46 & 0.48 & 0.48 & 0.48 & \\
\hline 7 & 0.38 & 0.41. & 0.41 & 0.41 & \\
\hline 8 & 0.28 & 0.30 & 0.30 & 0.30 & \\
\hline 9 & 0.18 & 0.18 & 0.18 & 0.18 & \\
\hline 10 & 0.13 & 0.13 & 0.13 & .0 .13 & \\
\hline
\end{tabular}

Table 4.31 Wall Defilection. Readings, (mm); Test no.13.

\begin{tabular}{|c|c|c|c|c|c|c|}
\hline Level & \multicolumn{2}{|c|}{ Hordzontal Loa } & \multicolumn{2}{|c|}{ Component Values, } & & $\mathrm{KN} / \mathrm{m}^{2}$ \\
\hline 1 & 0.64 & 0.94 & 1.42 & 2.41 & & \\
\hline 2 & 0.58 & 0.79 & 1.12 & 1.73 & $=$ & \\
\hline 3 & 0.64 & 0.81 & 1.07 & 1.50 & & \\
\hline 4 & 0.53 & 0.66 & 0.84 & 1.14 & & \\
\hline 5 & 0.43 & 0.53 & 0.66 & 0.89 & & $\cdot$ \\
\hline 6 & 0.33 & 0.38 & 0.48 & 0.61 & & \\
\hline 7 & 0.30 & 0.38 & 0.46 & 0.56 & & \\
\hline 8 & 0.30 & 0.36 & 0.41 & 0.51 & & \\
\hline 9 & 0.20 & 0.25 & 0.28 & 0.33 & . & \\
\hline 10 & 0.18 & 0.20 & 0.23 & 0.25 & & \\
\hline
\end{tabular}


Table 4.32 Wall Deflection Readings, (mm); Test no.14.

\begin{tabular}{|c|ccccc}
\hline & \multicolumn{6}{|c}{ Horizontal Load Component Values, KN/m } \\
Level & 0 & 5 & 10 & 15 & 20 \\
\hline 1 & 0.56 & 0.46 & 0.28 & 0.03 & -0.28 \\
2 & 0.74 & 0.69 & 0.58 & 0.43 & 0.25 \\
3 & 0.81 & 0.79 & 0.71 & 0.64 & 0.53 \\
4 & 0.74 & 0.74 & 0.69 & 0.64 & 0.56 \\
5 & 0.64 & 0.64 & 0.64 & 0.61 & 0.58 \\
6 & 0.53 & 0.53 & 0.53 & 0.53 & 0.51 \\
7 & 0.51 & 0.51 & 0.51 & 0.51 & 0.51 \\
8 & 0.38 & 0.38 & 0.38 & 0.38 & 0.38 \\
9 & 0.28 & 0.30 & 0.30 & 0.30 & 0.30 \\
i0 & 0.28 & 0.28 & 0.28 & 0.28 & 0.28
\end{tabular}

Table 4.33 Wall Deflection Readings, (mim); Test no.15.

\begin{tabular}{|c|ccccc}
\hline \multirow{2}{*}{ Leve1 } & \multicolumn{5}{|c}{ Hor1zontal Load Component Values, $\mathrm{KN} / \mathrm{m}^{2}$} \\
\hline 1 & 0 & 5 & 10 & 15 & 17.6 \\
\hline 2 & 0.51 & 0.69 & 1.04 & 1.83 & 2.64 \\
3 & 0.61 & 0.71 & 0.97 & 1.42 & 1.91 \\
4 & 0.69 & 0.76 & 0.94 & 1.24 & 1.52 \\
5 & 0.61 & 0.66 & 0.76 & 0.94 & 1.12 \\
6 & 0.79 & 0.56 & 0.66 & 0.79 & 0.91 \\
7 & 0.46 & 0.46 & 0.53 & 0.61 & 0.66 \\
8 & 0.38 & 0.38 & 0.46 & 0.51 & 0.56 \\
9 & 0.33 & 0.33 & 0.36 & 0.41 & 0.43 \\
10 & 0.23 & 0.23 & 0.28 & 0.30 & 0.33 \\
& 0.15 & 0.18 & 0.18 & 0.20 & 0.23
\end{tabular}


Table 4.34 Wall Deflection Readings, (mm); Test no.16.

\begin{tabular}{|c|ccccc}
\hline \multirow{2}{*}{ Leve1 } & \multicolumn{5}{|c}{ Horlzontal Load Component Values, KN $/ \mathrm{m}^{2}$} \\
\hline 1 & 0 & 6 & 12 & 18 & 21 \\
\hline 2 & 0.25 & 0.15 & -0.18 & -1.37 & -3.20 \\
3 & 0.25 & 0.20 & 0.05 & -0.28 & -0.76 \\
4 & 0.25 & 0.20 & 0.13 & 0.00 & -0.08 \\
5 & 0.23 & 0.20 & 0.13 & 0.08 & 0.05 \\
6 & 0.23 & 0.23 & 0.18 & 0.15 & 0.13 \\
7 & 0.25 & 0.25 & 0.23 & 0.20 & 0.20 \\
8 & 0.18 & 0.18 & 0.15 & 0.15 & 0.15 \\
9 & 0.15 & 0.15 & 0.15 & 0.15 & 0.13 \\
10 & 0.13 & 0.13 & 0.13 & 0.13 & 0.10 \\
\hline & 0.08 & 0.08 & 0.08 & 0.08 & 0.05 \\
\hline
\end{tabular}

Table-4:35 Wall Deflection Readings, (mm); Test no.17.

\begin{tabular}{|c|ccccc}
\hline & \multicolumn{5}{|c}{ Hortzontal Load Component Values, $\mathrm{KN} / \mathrm{m}^{2}$} \\
Level & 0 & 5 & 10 & 15 & 17.4 \\
\hline 1 & 0.38 & 0.48 & 0.71 & 1.17 & 1.52 \\
2 & 0.30 & 0.36 & 0.31 & 0.81 & 1.04 \\
3 & 0.30 & 0.38 & 0.51 & 0.74 & 0.89 \\
4 & 0.28 & 0.30 & 0.38 & 0.53 & 0.64 \\
5 & 0.25 & 0.28 & 0.36 & 0.51 & 0.56 \\
6 & 0.23 & 0.23 & 0.28 & 0.36 & 0.41 \\
7 & 0.25 & 0.30 & 0.36 & 0.43 & 0.48 \\
8 & 0.20 & 0.28 & 0.33 & 0.41 & 0.43 \\
9 & 0.20 & 0.25 & 0.28 & 0.36 & 0.38 \\
10 & 0.15 & 0.15 & 0.18 & 0.20 & 0.23
\end{tabular}


Table 4.36 Wall Deflection-Readings, (mm); Test no.18.

\begin{tabular}{|c|ccccc}
\hline \multirow{2}{*}{ Leve1 } & \multicolumn{6}{|c}{ Horizontal Load Component Values, $\mathrm{kN} / \mathrm{m}^{2}$} \\
\hline 1 & 0 & 5 & 10 & 15 & 20 \\
\hline 2 & 0.41 & 0.23 & -0.05 & -0.38 & -0.94 \\
3 & 0.53 & 0.41 & 0.25 & 0.10 & -0.20 \\
4 & 0.53 & 0.48 & 0.38 & 0.28 & 0.13 \\
5 & 0.53 & 0.48 & 0.43 & 0.36 & 0.25 \\
6 & 0.48 & 0.48 & 0.43 & 0.41 & 0.36 \\
7 & 0.43 & 0.43 & 0.41 & 0.41 & 0.38 \\
8 & 0.38 & 0.38 & 0.38 & 0.38 & 0.36 \\
9 & 0.30 & 0.33 & 0.30 & 0.30 & 0.30 \\
10 & 0.25 & 0.25 & 0.25 & 0.25 & 0.25 \\
& 0.23 & 0.23 & 0.23 & 0.23 & 0.23 \\
\hline
\end{tabular}

Table 4.37 Wall Deflection Readings, (m); Test no.19.

\begin{tabular}{|c|ccccc}
\hline \multirow{2}{*}{ Leve1 } & \multicolumn{5}{|c}{ Horizontal Load Component Values, $\mathrm{kN} / \mathrm{m}^{2}$} \\
\hline 1 & 0 & 5 & 10 & 16 & 20 \\
\hline 2 & 0.43 & 0.53 & 0.69 & 0.94 & 1.24 \\
3 & 0.46 & 0.53 & 0.64 & 0.79 & 1.02 \\
4 & 0.43 & 0.51 & 0.58 & 0.69 & 0.84 \\
5 & 0.41 & 0.43 & 0.48 & 0.56 & 0.64 \\
6 & 0.38 & 0.43 & 0.46 & 0.53 & 0.61 \\
7 & 0.33 & 0.38 & 0.38 & 0.43 & 0.48 \\
8 & 0.30 & 0.36 & 0.36 & 0.41 & 0.56 \\
9 & 0.25 & 0.28 & 0.28 & 0.30 & 0.36 \\
10 & 0.20 & 0.23 & 0.23 & 0.25 & 0.28 \\
& 0.10 & 0.13 & 0.13 & 0.15 & 0.15 \\
\hline
\end{tabular}




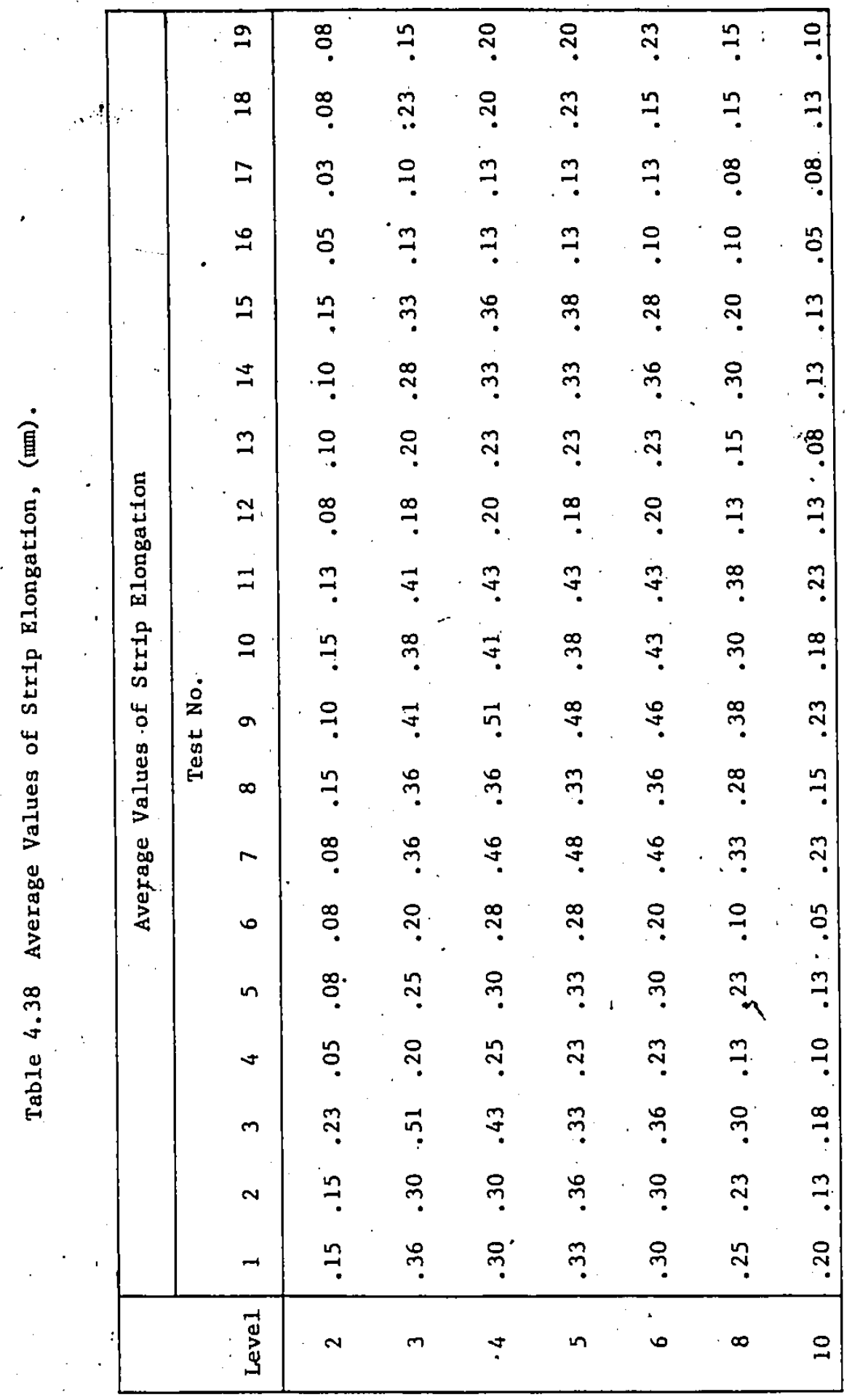




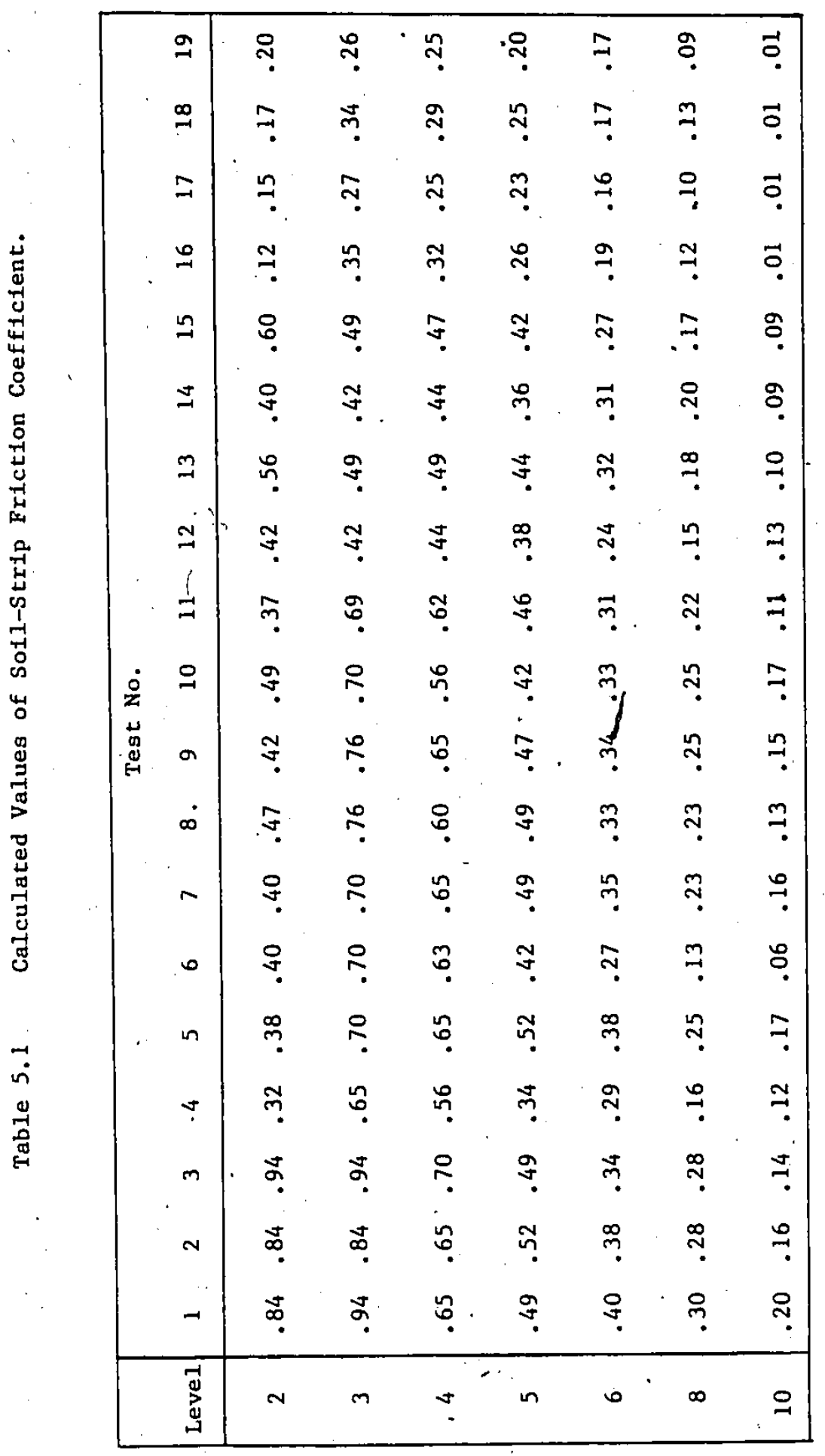


APPENDIX III

CALIBRATION OF THE STRAIN GAUGES

Using a Universal Testing Machine, preliminary stress-strain tests on a strip instrumented with strain gauges indicated differences in the strain readings, between a dial gauge reading and the strain gauge readings, and even some differences between the strain gauge readings themselves, see F1g.3.4. These different values of strain would have led to several different values of Young's modulus for the one strip. In order to avold any confusion in obtaining the stress values from the strain gauge readings, each strain gauge was calibrated, by performing a stress-strain test on each fully instrumented strip, prior to placement in the reinforced earth retaining wall. The 1nstrumented strlp was suspended from a hanger through the plate used in afflxing the strip to the wall face. A welght of $3 \mathrm{lbs}$., (1.36 kg.), was suspended from the free end of the strip, and all the strain gauges were zeroed. Then three load increments of $101 \mathrm{bs} .(4.45 \mathrm{~kg}$. each were added to the existing weight, and strain readings were taken at each increment. Knowing the cross-sectional area of the strip, $\left(6.45 \times 10^{-7} \mathrm{~m}^{2}\right)$, and any given load fncrement, the stress increment was thus determined. Thus stress-strain relationships were determined for each strain gauge, and although all different, they reflect the true stress existing in the strip.

Values of the stress-strain relationships for the gauges are presented in Table III.'l. Note that strip nos. 3,4 and 5 were replaced during the experimental programme, as some of the gauges had failed. 
Table III.1 Values of the Stress/Strain Ratio for the Straln Gauges.

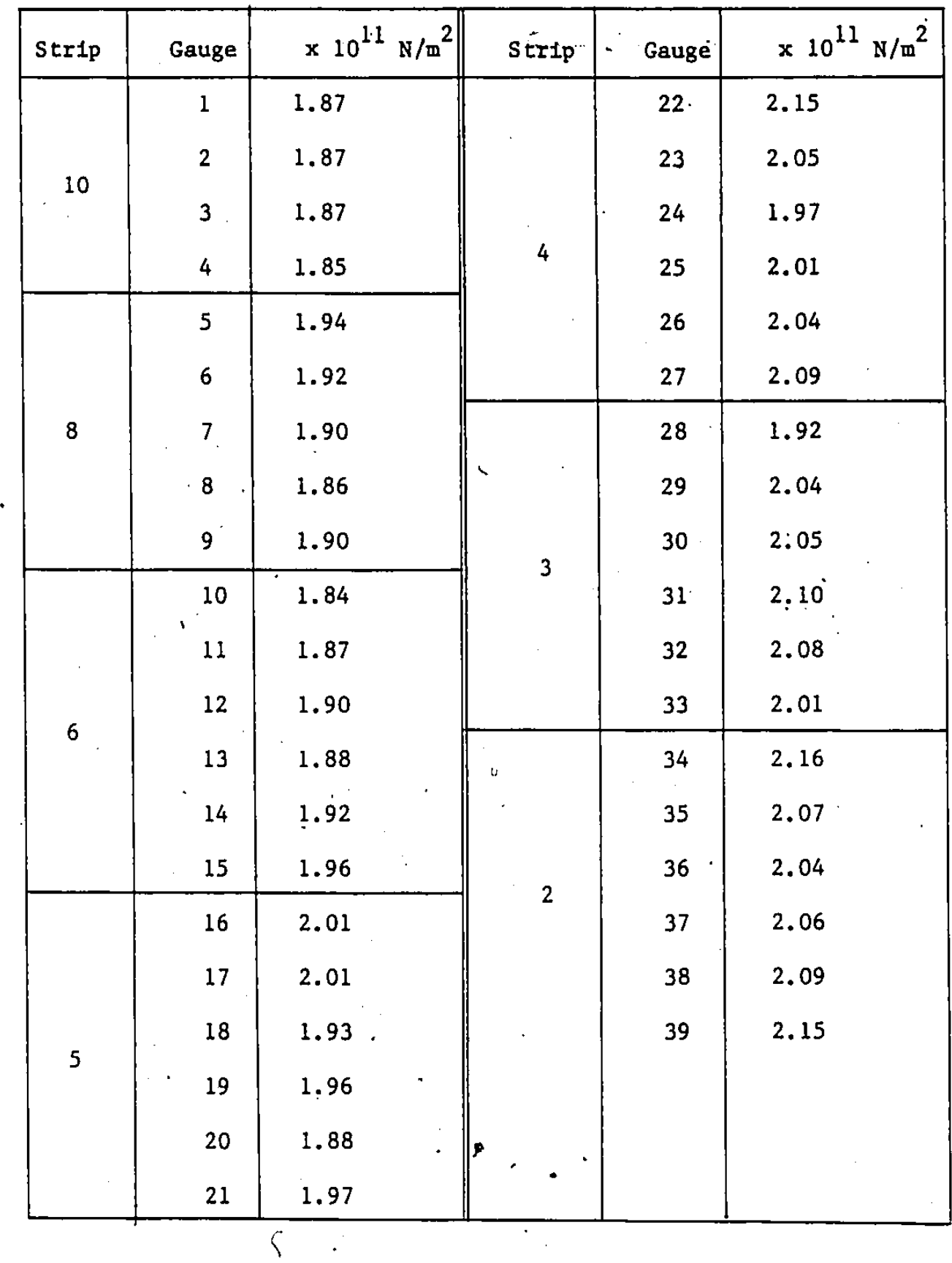

Q 


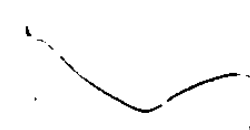

Table III.l Values of the Stress/Strain Ratio for the Strain Gauges on the Replaced Strips.

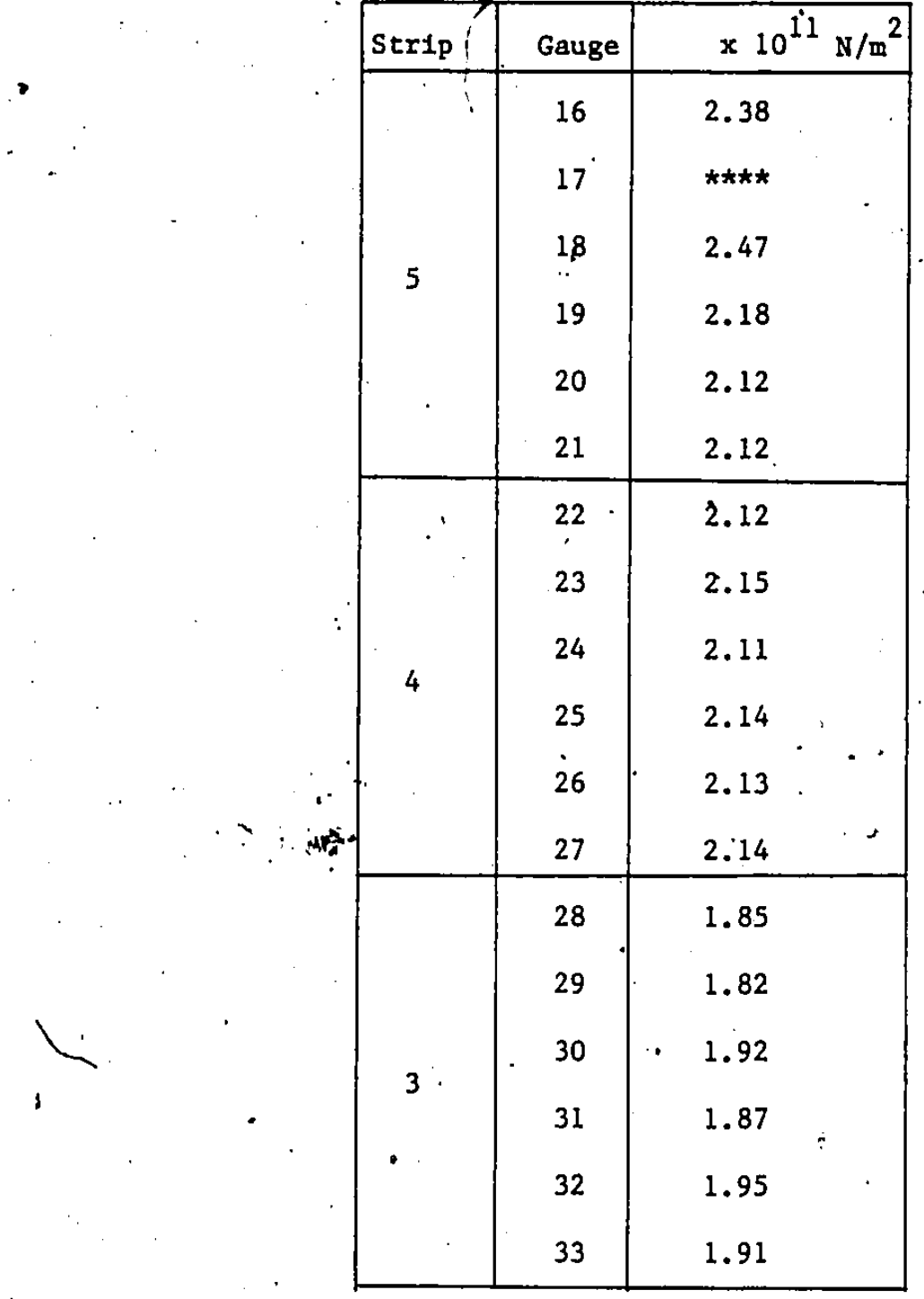

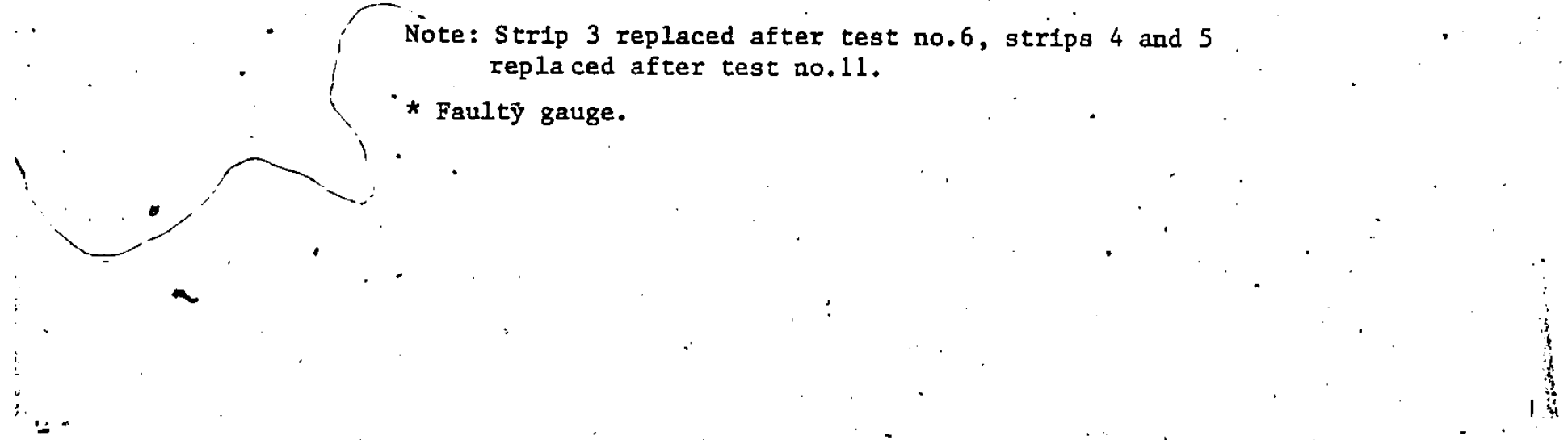




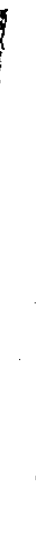

\section{APPENDIX IV \\ SAMPLE CALCULATIONS}

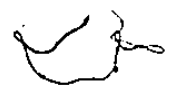

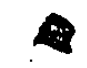


From table III.I the stress-strain ratio for gauge no. 29 , strip no. 3 , . is $1.82 \times 10^{11} \mathrm{~N} / \mathrm{m}^{2}$, as determined by the method outlined in Appendix III. The strain readings for this gauge for test no. 11 are as follows (strain values are micro-strain, i.e. $\times 10^{-6}$, :

$$
\begin{array}{rrrrr}
\multicolumn{1}{c}{\mathrm{H}} & \mathrm{KN} / \mathrm{m}^{2} & & \\
0.0 & 6.5 & 13 & 19.5 & 26 \\
1041 & 1224 & 1454 & 1702 & 2040
\end{array}
$$

multiplying the above strain readings by $1.82 \times 10^{11}$ yields values of -stréss as follows, (stress values are $\times 10^{7^{\circ}}, \mathrm{N} / \mathrm{m}^{2}$ ) :

\begin{tabular}{ccccc} 
& \multicolumn{3}{c}{$\mathrm{H}$} & $\mathrm{KN} / \mathrm{m}^{2}$ \\
0.0 & 6.5 & 13 & 19.5 & 26 \\
18.95 & 22.28 & 26.46 & 30.98 & 37.13
\end{tabular}

thus the stress increments for each horizontal load component are as follow's, (stress values are $\times 10^{7}, \mathrm{~N} / \mathrm{m}^{2}$ ) :

$\begin{array}{cccccc}\mathrm{H} & 0.0 & 6.5 & 13 & 19.5 & 26 \\ \text { Stress } & 0.0 & 3.33 & 7.51 & 12.03 & 18.18\end{array}$

Using linear regression to determine the slope of the relationship between the horizontal load component and the change in the strip stress yields a vàlue of 6,932, (see Fig.4.60). To adjust this value to. a contour value of the ratio of the change in the soil stress to the horizontal load component, it is multiplied by a value of $6.481 \times 10^{-5},(=\mathrm{A} /(\mathrm{ds} . \mathrm{dh}))$. 


\section{REFERENCES}

1. Akinmuguru,J.0., and Aklabolade, J.A., "Stability of Loaded Footinis on Reinforced Soll," Jourllal of the Geotechnicul Enuineering Dlvision, ASCE, Vol.107, No.GT6, June, $1981, \mathrm{pp} .819-827$.

2. Al-Hussaini,M., and Johnson, L.,D., "Numerical Analygis of "Reinforced Earth Wall", Procesdinus of symnositim on Earth Beinforcement, Geotechnical Engineering Division, ASCE, Pittsburg, ApriL, 1978, pp.9o-126.

3. Al-Hugsaini, M., and Perry, E.H., "Fiela Exferiment of Reinforced Earth Wall", Proceedinus of Symrosiem 20

- Hirth keinforcement; Geotechnical Engineering Division, ASCE, Pittsburg, Ajril, 1978, pp.127-156.

4. Bacot,J., I litis, M., Laureal, P, Paumier, T, and Santzleratio., "Study"ot the Soil keinforcement friction coefficient", Proctedings of Symensiom en Eartb Beinforcement, Geotechrical. Engl neering Division, $A S C E$, Pittsburu, April, 1978, pP.157-185.

5.. Biquelin,F., "Construction a nd lnstrumentation of keinforced Eurth Walls in French Highwily Administration", Proceedinus of Symuesiom an Edrth : Reintorcement, Geotechnical Engineering Division, ASCE, Pittsburg, April, 1378, jp.18i-201.

6. Bassett, K.H., and Last,N.C., "Reinforcinfs Earth below Footiniss and Embankments", Proceedinas of Symuesiom in Eurth Kelinercement, Gentechnical Engineering Division, ASCE, Pittsburg, April, 1978, pp.202-231.

7. Binquet, J., and Lee, $\mathrm{K} \cdot \mathrm{L}$, , "Bearing Capacity Tests on. Reinforced Earth Slabs", Journst of the Gentechnical Enkingerinu bivision, ASCE, Vol.101, No.GT12, Decemijer, 1.975, PP. 1241-1255.

S. Chang,J.Cs, and Forsyth,k.A., "Design and Fielat Jehisviour of keluforced Earth Wall", Journul ob' tha Geotechnisal Ensineerdng Dlvision, ASCli, Vol.10:3, No.fjt7, Jully, 1977, pp.677-692. 
9. Darbin, M., Jailloux, J-M., and Montuelle, J., "Performunce and Reseurch on the Durablitity of Reinforced Furth Keinforcing strips", Hegceedinus of Sympegien on Esrth Reinfercement, cootechnical Endineering Division, ASCE, Pittsburg, April, 1978, pp. 3Q5-.333.

10. Duncan,J.M., and Chang,C-Y., "Nonlinear Analysis of stress and Strain in Soils", Jeurnal ot the Soll Mechanlesi and Eoundations Division, Proceedings of ASCE, Vol.96, No.SMS, September, 1970, pp.1629-16.5.

11. Gerrurd,c.x., and Warde,b.J." "Solutions for Line Loads and Generalized Strip Loads Applied to an Orthorhoxbic Half Space", Division of Amplied Geomechanics Ieshnical paper No. 14, Cusamonwealth Scientific and Industrial Research Organilation, Australia, 1973.

12. Harrison, *.S., and Gerrard,C.M., "Elastic Iheory Applied to Reinforced Earth", Jeucnal of the Seil Jechanics and Eounditions Dlvision, Proceedin's or ASCE, Vol.98, No.SAl2, December, 1972, ap.1325-13+5.

13. Haustainn, Y.K., and Lee, I.K., "Strength Charecteristics of Reinfurced Earth", New Herizons in construction Vaterials, Envo Publishink Co., Vol.1, 1376 .

14: Juran, I., and Schlosser, F., "Theoretical Analysis ot Fisilure in Reinforced Earth Structures", proceedilliat of ixmugiem on Eurth Keinfercement, Geotechnical Entzineering Division, ASCE, Pittshure, April, 1978, pp. $528-555$.

15. Juran, I. Schiosser, F, Lorj,N.T., and Legeay,G., "full Scale Experiment on a keinforced Bridue Alutment in Lille", Proseedinus of Synnesium on Earth kelnforsement, Geotechnicul Engineering Division, $A, s C E$, Pittsbura, April, 1978, pp.556-584.

16. Kennedy, J.B., Laba,J.T., and Mossad, A.A., "Reintorcer Earth Retuining Walls Under Strip Load", Canadian leetechnical Jeurenal, Vol.17, No.3, 1930, pp.382-394.

17. Lee,k.L., Adams, B.D., and Vagneron,J., "keintorcell Earth Retuining Wills", Jeurnul ef suil lechanics and Eoundations Division, Proceedings ASCF, Vol.95, No.sirin, ictuluer, 1973, pp.745-763.

13. McKittrick, D.P., "Keinforced Earth: Application of Theory"ind Research to Practice", Kevnote Iduress,

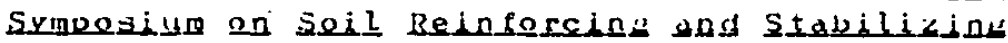
Iechnimues New South vales Institute of Technolugy, Sydney, dustralia, October, is78. 
19. heyurhuff,k.6, "some kecent liesearch on learinj

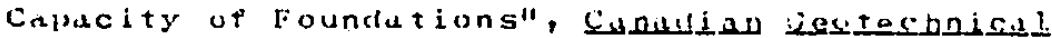
Jiusnat, vol.1,1063, pp.16-20.

20. Yinistere des Transports, "Les cuvrajes en rerre trmee: Recomandations et fegleg de l'art." Le ksubratoires

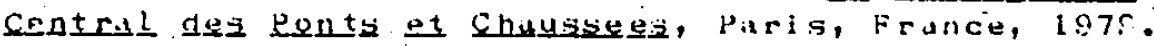

21. Mossuad, d. V., "Reinforced Furth Retiaininy dulls subjected to Stril" Loadin! Surcharge", Naster's Thesi=, Faculty of Graduate Studies, University of Winctsor, 1.777 .

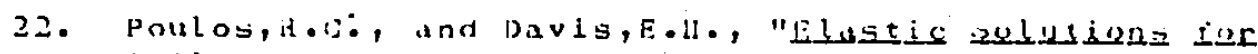

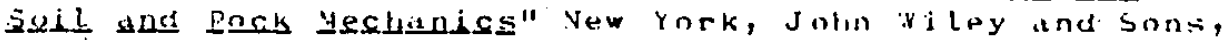
Ine., 1! 7t, 10.37.

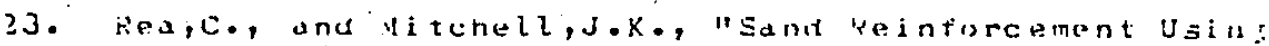

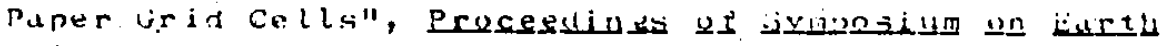
Besintorcegent, jeotechnicul lingineering Division, Asct, Pittsilura, Akril, 1578, ppeistit-toil.

24. Schlosser,f., and Filias, v., "friction in tieinforced

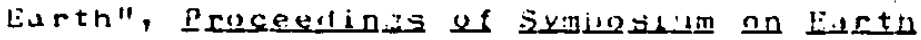

Peinferesgent, Geutechnical En:i inpering ivivision, AiCk, Pittsiura, April, 1973 , Ep.730-71,.?.

25. Fehlosscr,F., and long N.T., "lecent tresults in leneh iesearch in ?eintorced Eartu", Isurnal is the Constructiun livision, Proceedinoti A Sil, vol.11), vis.coj, sejtemleer $1.374, j p .22 .3-237$.

26. SchlosserFF., and vidul, ll," "ieinfurced Farth",

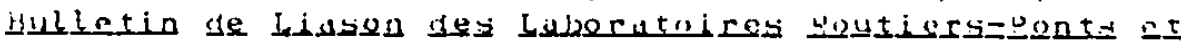

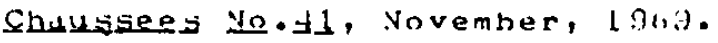

27. Shen, C-k., kumstad, K, 4., dud aerinann, h..., "Inte, raten study of ieinforced Earth -I I Jehaviour und Jesi in",

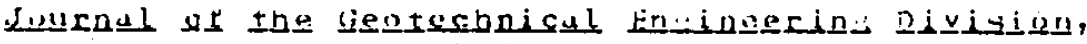
Proceedings ASCE, Vol. L1)2, Vo.6T6, June 1576 , pr..577-5g0.

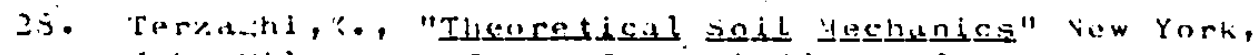

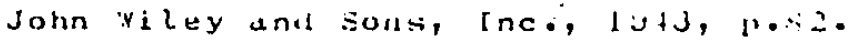

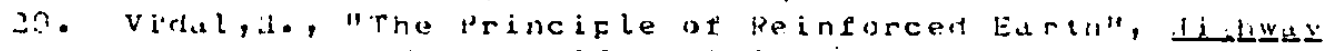

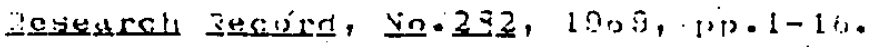

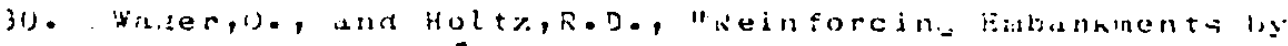

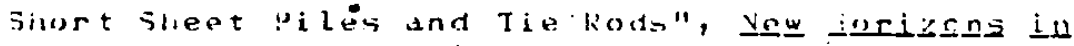

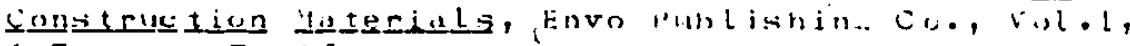
$1: 70, p p \cdot 17 s-191$. 
The author was born on the Twenty Fourth of Apri1, 1957, in Dublin, Ireland. In June of 1975 he finished his secondary schooling, obtaining the required Leaving Certiflcate from Glenstal Abbey School, Limerick. In October of the same year he entered into the CIvil Engineerfing programme at University College Dublin. In July of 1979 he graduated from University College Dublin with his Bachelor's degree in Civil Engineering. Thereupon he spent some six months working as resident engineer on a hospltal construction project in Dublin. Following this he came to Canada, and enrolled in September of 1980 in a Master's programme in the Department of Civil Englneering at the University of Windsor, Windsor, Ontar1o, Canada. 